\title{
2. SITE 463: WESTERN MID-PACIFIC MOUNTAINS ${ }^{1}$
}

\author{
Shipboard Scientific Party ${ }^{2}$
}

\section{HOLE 463}

Date occupied: 2 August 1978 (1708Z)

Date departed: 10 August 1978 (1515Z)

Time on hole: 190.2 hours

Position (latitude; longitude): $21^{\circ} 21.01^{\prime} \mathrm{N} ; 174^{\circ} 40.07^{\prime} \mathrm{E}$

Water depth (corrected $\mathrm{m}$, echo sounding): 2525

Bottom felt (m, drill pipe): 2532

Penetration (m): 822.5

Number of cores: 92

Total length of cored section (m): 822.5

Total core recovered $(\mathrm{m}): 301.8$

Core recovery $(\%): 36.6$

Oldest sediment cored:

Depth sub-bottom (m): 822.5

Nature: limestone

Age: Early Cretaceous (Barremian)

Basement: Not reached

Principal results: The main objectives at Site 463 (Fig. 1) were to continuously core to igneous basement, in order to determine the geologic history of the western Mid-Pacific Mountains and to rucover a complete pelagic record for biostratigraphic and paleoceanographic interpretations. lgneous basement was not reached, even though 822.5 meters were cored. The sediments and sedimentary rocks were divided into four major lithologic units (Fig. 2). The oldest unit, at least 190 meters thick, is interbedded pelagic and clastic limestone of Early Cretaceous (Barremian) age. Shallow-water carbonate debris containing oolites, mollusk fragments, stromatolite fragments, and rare glauconite grains makes up most of the clastic limestone beds. An overlying unit, 45 meters thick, consists of cyclic carbonaceous limestone of Early Cretaceous (early Aptian) age, with volcanic ash. The abundant ash in this interval indicates frequent volcanic activity on nearby islands. The high organic-carbon content of some beds is strong evidence for a sequence of anoxic events that are of at least regional and possibly worldwide importance. The overlying unit, 136 meters thick, is composed of multicolored pelagic limestone beds with chert as a common component; it is early Aptian through middle Albian in

\footnotetext{
${ }_{2}^{1}$ Initial Reports of the Deep Sea Drilling Project, Volume 62.

2 Jörn Thiede (Co-Chief scientist), Department of Geology, University of Oslo, Blindern, Oslo 3, Norway; Tracy L. Vallier (Co-Chief scientist), U.S. Geological Survey, Menlo Park, California; Charles Adelseck, Jr., Deep Sea Drilling Project, Scripps Institution of Oceanography, La Jolla, California; Anne Boersma, Lamont-Doherty Geological Observatory, Palisades, New York; Pavel Cepek, Bundesanstalt für Geowissenschaften und Rohstoffe, Hannover, Federal Republic of Germany; Walter E. Dean, U.S. Geological Survey, Denver, Colorado: Naoyuki Fujii, Department of Earth Sciences, Kobe University, Nada Kobe, Japan; Vlo University

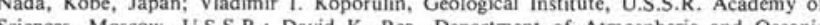
Sciences, Moscow, U.S.S.R. David K. Rea, Department of Atmospheric and Oceanic Science, University of Michigan, Ann Arbor, Michigan; Constance Sancetta, LamontDoherty Geological Observatory, Palisades, New York; William Sayre, Department of Oceanography, University of Southampton, Southampton, United Kingdom (present address: Department of Earth Sciences, lowa State University of Science and Technology, Ames, lowa); André Schaaf, Institut de Géologie, Strasbourg, France; Ronald R. Schmidt, Institute of Earth Sciences, University of Utrecht, Utrecht, The Netherlands; Karl E. Seifert, Department of Earth Sciences, lowa State University of Science and Technology, Ames, lowas Edith Vincent, Geological Research Division, Seripps Institution of Oceanography, Jowa, Edith Vincent, Geological Research Division, Scripps Institution of Oceanography, La olla, California, Kenneth E. Windom, Depar of Science and Technology, Ames, lowa.
}

age. The top unit is divided into two sub-units. The oldest sub-unit is $\mathbf{4 0 5}$ meters thick and ranges in age from late Albian to early Maastrichtian. Rock and sediment types are nannofossil and foraminifer chalk, nannofossil and foraminifer ooze, and limestone with minor amounts of chert and porcellanite. The youngest subunit of the top lithologic unit, 47 meters thick, is nannofossil ooze of early Eocene through Pleistocene age. The calcareous planktonic faunas and floras in the Miocene and Pliocene oozes are heavily dissolved, despite the relatively shallow depth of deposition at this site. The base of the youngest sub-unit marks a major hiatus between lower Eocene and lower Maastrichtian sediments. Seismic-reflection profiles show three major reflectors. The top one, observed only on the $3.5-\mathrm{kHz}$ records, marks the boundary between the Tertiary and Maastrichtian nannofossil-ooze beds. The second one marks the top of the limestone beds, at about 250 meters, that lie within the lower sub-unit of lithologic Unit I. The third marks the boundary between the top lithologic unit and the underlying unit of Lower Cretaceous limestone beds, at about 450 meters sub-bottom depth. At least two reversed-polarity intervals can be identified in the Chiastozygus litterarius nannoplankton zone, which may correlate with anomaly M0 or a reversed interval that was identified at DSDP Hole 361 in the south Atlantic.

\section{BACKGROUND AND OBJECTIVES}

The late Mesozoic and Cenozoic paleoenvironment of the central North Pacific region was the main target of the sites drilled during Leg 62 of the Deep Sea Drilling Project. The deposits were expected to contain remains of several, if not all, important pelagic microfossil groups. The selected sites were therefore located on structural highs where calcareous sediments are preserved, whereas calcareous components have been dissolved over wide regions of the deep North Pacific basins. Carbonate deposits capping the Mid-Pacific Mountains (Hamilton, 1956) southwest of the Hawaiian Ridge were chosen to be drilled at the first site. We planned to recover upper Mesozoic and Cenozoic sedimentary sections, as well as to reach rocks of the Upper Jurassic(?)Lower Cretaceous volcanic platform of the northwestern Mid-Pacific Mountains (Larson, 1976). The primary objective at this site, however, was to obtain lower Tertiary and upper Mesozoic sections. The lower Tertiary and upper Mesozoic planktonic record is scanty in this part of the North Pacific; thus, good and complete sections were needed for both biostratigraphic and paleoceanographic interpretations. The study of upper Mesozoic and lower Tertiary sediments from this locale would provide fundamental insight into the characteristics of planktonic communities, paleocirculations, and fertility patterns during a period of major biological crises associated with the Mesozoic/Cenozoic boundary.

The Mid-Pacific Mountains constitute one of the large aseismic rises in the central and northern Pacific Ocean whose nature, origin, and age are disputed. General morphology of the Mid-Pacific Mountains is shown 


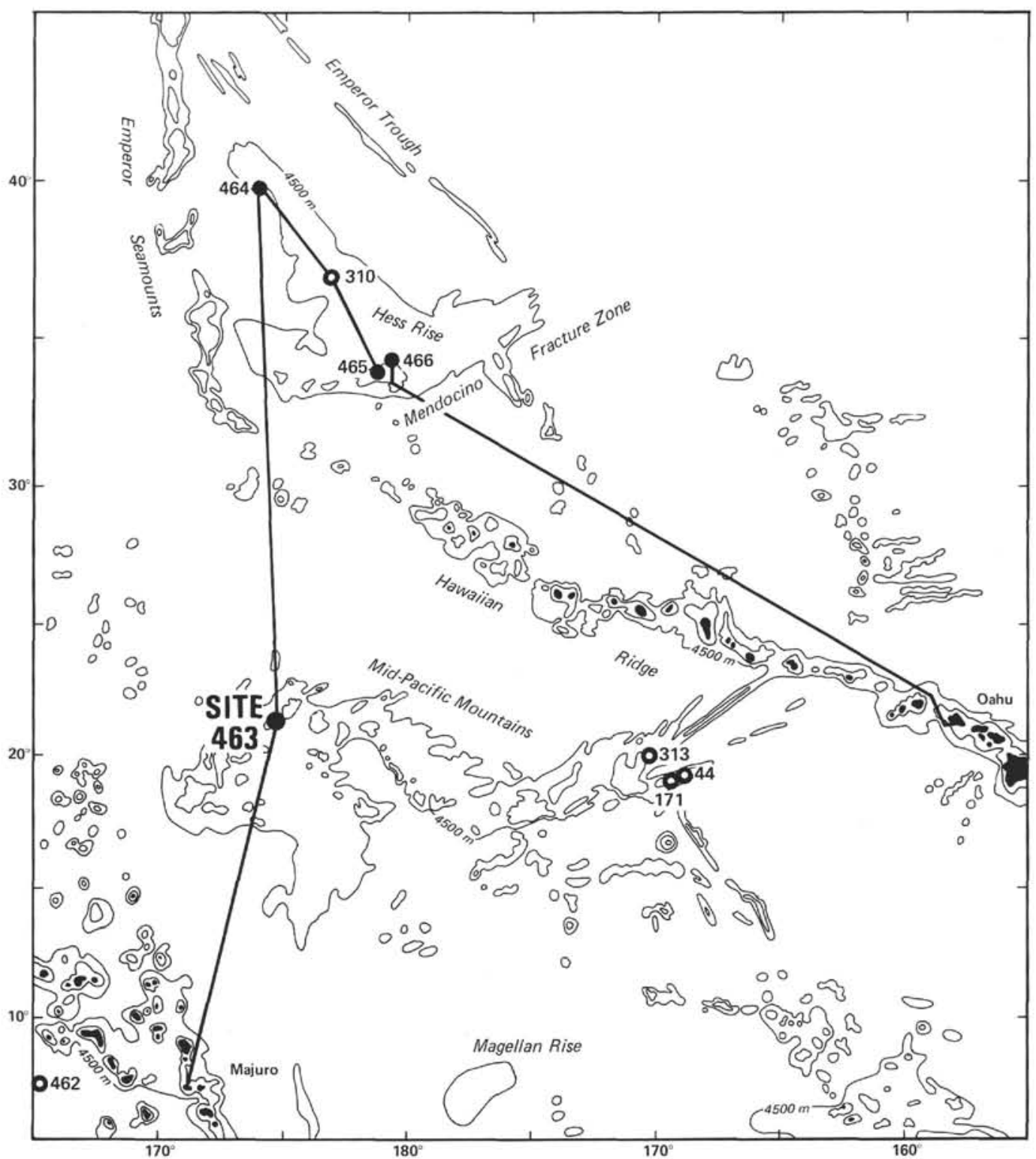

Figure 1. Location of DSDP sites in the central North Pacific.

in Figure 3. It is not clear how its position is related to the ancestral plates of the Mesozoic Pacific Ocean (Larson, 1976). Basaltic rocks recovered at Sites 313 and 171 in the eastern Mid-Pacific Mountains are believed to represent the volcanic basement (Larson, Moberly, et al., 1975), but they do not necessarily date the main constructional phase of the volcanic edifice. It is interesting to note that the ages obtained for the volcanic rocks found at Site 313 are $30 \mathrm{~m}$.y. younger than that from Site 171 (Saito and Ozima, 1973). Dredge hauls from guyots on the main Mid-Pacific Mountains platform indicate that during late Early and Late Cretaceous times the guyots were volcanic islands surrounded or capped by coral reefs (Hamilton, 1956). Since that time they must have undergone considerable subsidence (Winterer, 1976), because most of them are now under a few hundreds to a few thousands of meters of water.
The Mid-Pacific Mountains consist of several segments thought to be part of an ancient fracture-zoneridge-crest system that separated the North and South Pacific Plates during the Early Cretaceous (Larson, 1976). Sites had been drilled during DSDP Legs 6 (Heezen, Fischer, et al., 1971), 17 (Winterer, Ewing, et al., 1973), and 32 (Larson, Moberly, et al., 1975) in the Mid-Pacific Mountains, but the holes are on the northeastern segment, which probably followed one of the old fracture-zone trends.

The generalized lithologies of Holes 171 and 313 from the northeastern Mid-Pacific Mountains and a reconstruction of their probable paleodepths of deposition are shown in Figure 4. Dominantly calcareous Upper Cretacous and Cenozoic sediment sections at both sites have a hiatus across the Cretaceous/Tertiary boundary, and volcaniclastic sediments were observed in Cam- 
SITE 463

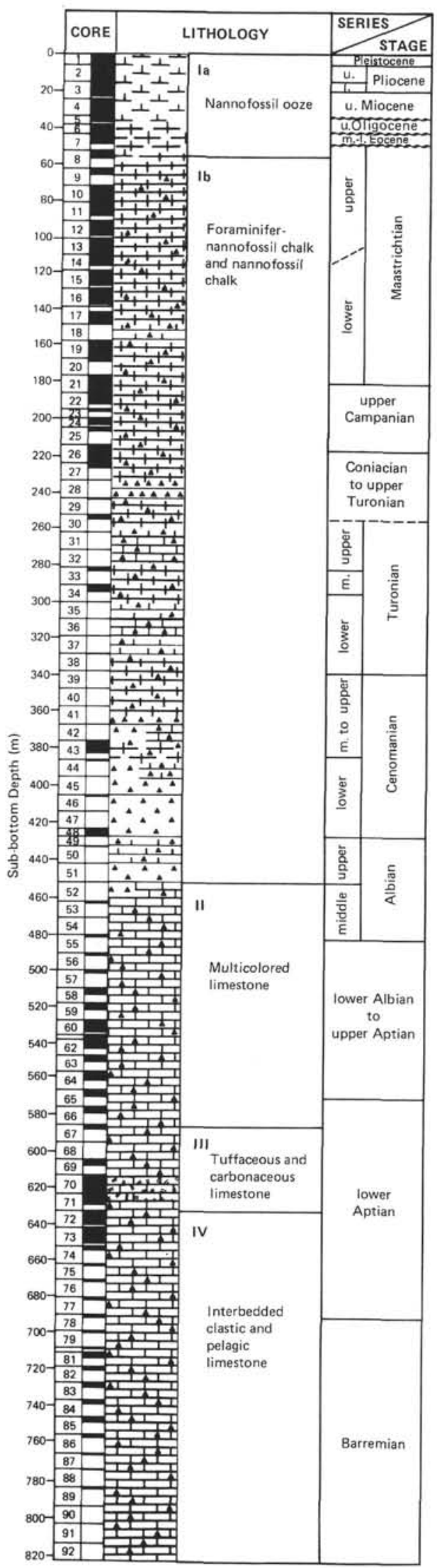

Figure 2. Lithologic column of Hole 463, Mid-Pacific Mountains. panian deposits. A thick volcaniclastic and limestone sequence reaching back into Cenomanian time had to be penetrated at Site 171 before recovering probably displaced, weathered basalt of the volcanic edifice (Winterer, Ewing, et al., 1973). Reworked fossils in the Cenomanian and plant remains in the volcaniclastic Turonian and Coniacian suggest that part of Horizon Guyot reached above the sea surface during Late Cretaceous time. Unfortunately, the oldest sediments recovered at Site 171 were not cored continuously. This, together with poor recovery, makes it impossible to reconstruct the earliest history of this site in detail, although a reconstruction of its subsidence suggests that the region around this site reached above the sea surface for at least the first $6 \mathrm{~m}$.y. of its existence. It is not clear whether the basalt recovered below the oldest sediments at Site 313 (Larson, Moberly, et al., 1975) represents an extrusive or intrusive volcanic rock, but its mineral assemblages suggest that it formed late in the volcanic evolution of these seamounts (Marshall, 1975).

During Leg 62, we planned to sample the segment of the Mid-Pacific Mountains along the western arm that follows an ancient fracture-zone trend close to the intersection with the fossil ridge crest (Larson, 1976). Magnetic anomalies M22 and M20, which abut this part of the Mid-Pacific Mountains northwest of Site 463, suggest that the floor of the adjacent deep northwest Pacific Basin is 140 to $150-\mathrm{m} . y$. old. All paleontological data and absolute ages of volcanic rocks from the MidPacific Mountains indicate that they are Early to midCretaceous in age. Although these ages range over a relatively wide time span, at least from Early to Late Cretaceous, age relationships among the various segments of the Mid-Pacific Mountains are not clear.

Apparently suitable drill-site locations had been found along the Mahi 7004 seismic-reflection profile (Fig. 5A). The anticipated sediment section close to proposed drill site MM-1 (Site 463) was believed to comprise an approximately 900 -meter-thick section. Three subsurface reflectors were thought to represent Eocene cherts, interfaces between the oceanic basement and overlying Mesozoic limestones, and interfaces between these limestones and the upper Mesozoic to lower Cenozoic chalks (Fig. 5B).

\section{OPERATIONS}

Leg 62 began after scientific staff members were exchanged in Majuro lagoon (Marshall Islands) on 28 July at $0300 \mathrm{Z}$. The first site to be investigated was 874 miles northeast of Majuro Atoll. Air-gun and magnetometer gear were streamed at $0455 \mathrm{Z}$, and we proceeded toward Site 463 on a heading of $015^{\circ}$ (Rea et al., this volume). At $1346 \mathrm{Z}$ on 2 August, we turned to a heading of $289^{\circ}$, paralleling the Mahi 7004 trackline (Fig. 6). At 1645Z, speed was reduced to 5 knots, and at $1708 \mathrm{Z}$ on 2 August the beacon was dropped. We continued on a course of $289^{\circ}$ for a half hour, pulled in the gear, and returned at $1752 \mathrm{Z}$ to the beacon. At $1942 \mathrm{Z}$, pipe lowering commenced. After the bottom-hole assembly and two stands of drill pipe were made up and run, a test was made on the new pressure core barrel (PCB). It was allowed to 


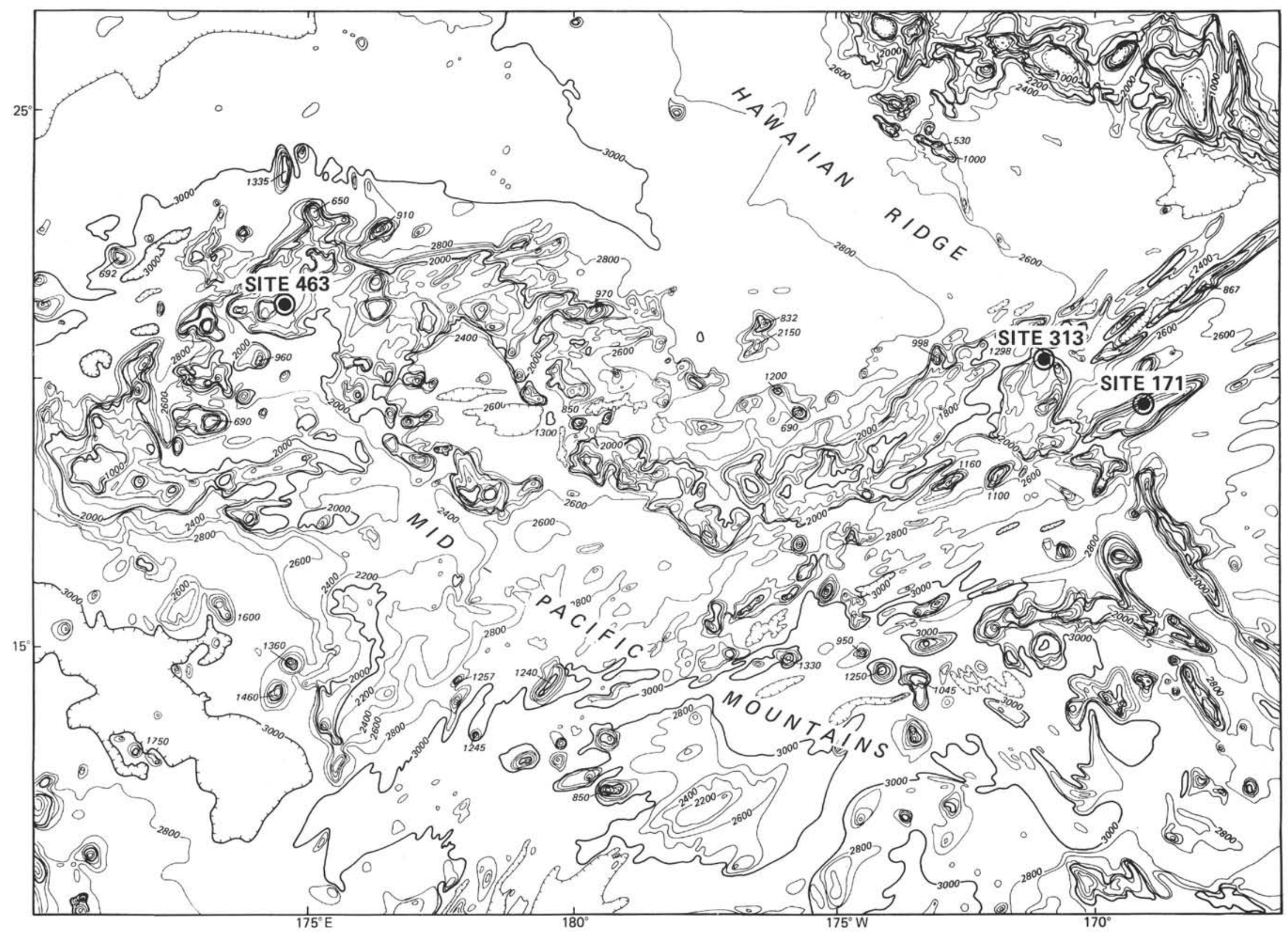

Figure 3. Bathymetry of the Mid-Pacific Mountains (after Chase et al., 1971), with the locations of DSDP Sites 463, 313, and 171. 
A

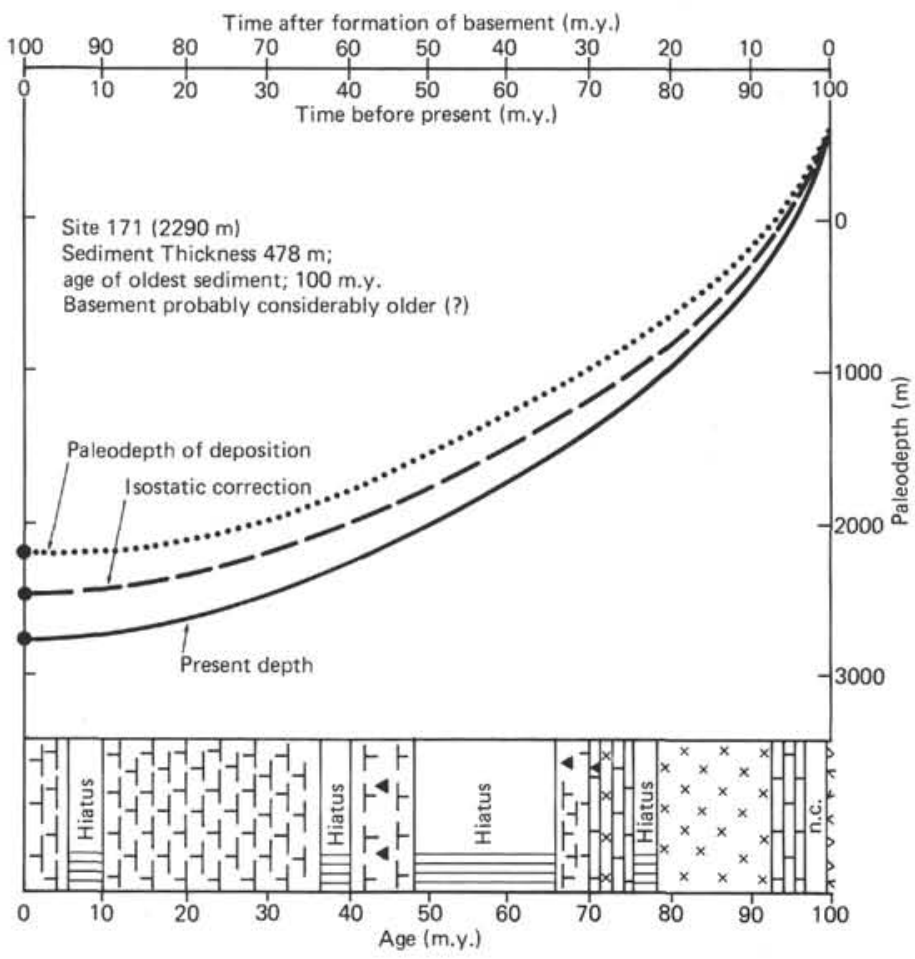

B

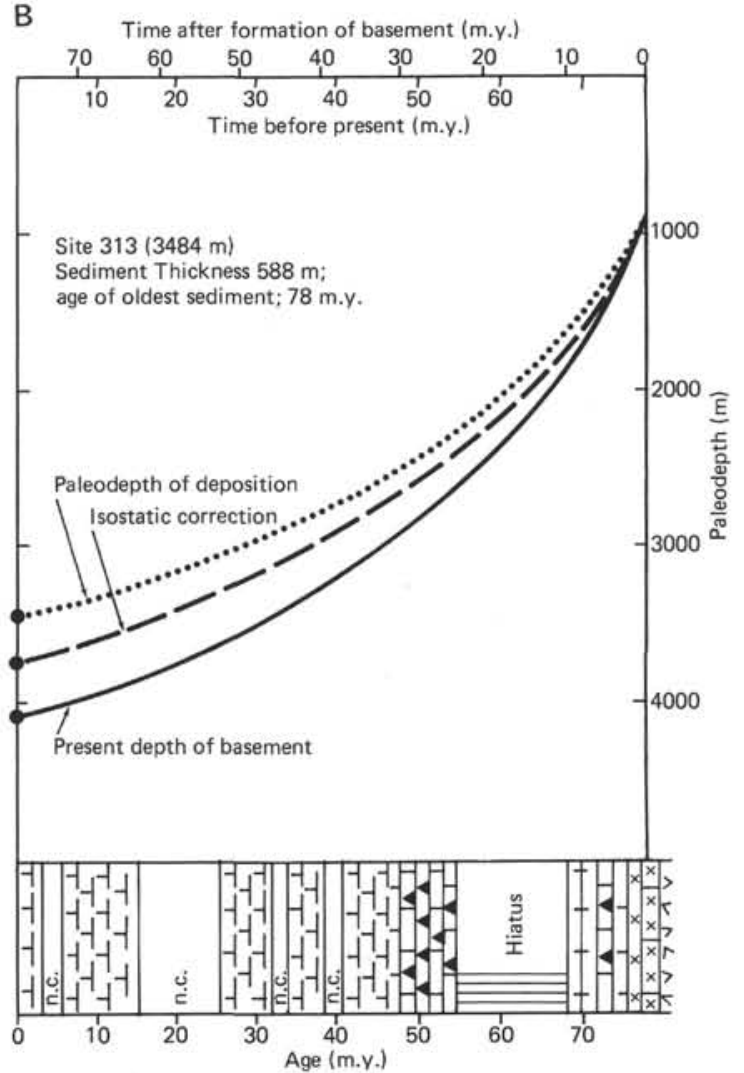

Figure 4. Subsidence and simplified lithologic columns of DSDP Sites 171 (A) (after Winterer, Ewing, et al., 1973) and 313 (B) (after Larson, Moberly, et al., 1975) in the eastern Mid-Pacific Mountains.

free fall at this point to determine if the tool would operate properly after landing. After this test, the drill pipe was made up and run to 2525 meters, when the Bowen sub was picked up. The hole was spudded, and the mud line was established at 2532 meters.

Water depth at Site 463 is 2525 meters (corrected from echo sounding; 2532 meters as measured by pipe length). A 5-second air-gun profile shows a sedimentary sequence nearly 1-second thick (Fig. 7), consisting of at least three acoustic layers. Acoustic basement is not visible. The proposed drilling program consisted of a single-bit hole to be continuously cored through the 900 meter ooze-chalk-limestone section and 100 meters into oceanic basement, or until bit destruction.

On-site operations were routine. A bit with a 2.25 inch $(570 \mathrm{~mm})$ opening was run, rather than one with a normal 2.5 -inch $(635 \mathrm{~mm})$ opening, in order to accommodate the pressure core barrel. Therefore, all cores cut at Site 463 have a somewhat smaller diameter than cores cut at previously drilled DSDP sites. The hole was continuously cored to 34 meters sub-bottom, where the first PCB core was taken (34.0-38.0 m sub-bottom). The hole again was cored continuously to 199.5 meters, where the next PCB core was taken (Core 23, 195.5$199.5 \mathrm{~m}$ sub-bottom); subsequently, the hole was continuously cored to a total sub-bottom depth of 822.5 meters, where it was abandoned because of bit destruction.

A drilling problem developed while Core 47 was being cut. After 4 meters had been cut, the pipe became stuck and could not be rotated, nor could water be circulated. However, the bumper subs still could be moved, which indicated that the pipe was stuck below this point. After working the pipe for 2 hours with pulls of up to 475,000 pounds, the inner core barrel was retrieved, and circulation was regained. Then 50 barrels of mud were added, and after 20 minutes the pipe came free and remained free until the hole was completed.

At $0239 \mathrm{Z}$ (1439L) on 3 August, the first core was on board, and we cored continuously until $0852 \mathrm{Z}$ (2052L) on 10 August. Ninety-two cores were attempted, to a final sub-bottom depth of 822.5 meters (Table 1). Recovery was 301.8 meters. Core recovery for the hole averaged $36 \%$. The main reason for the lower recovery was the chert, which was encountered early and again intermittently as the hole was deepened. Higher-thannormal pump pressure was required to prevent plugging of the bit, which resulted in washing away of softer sediments. The bit wore out before basement rocks were penetrated. We left the site at $1530 \mathrm{Z}$ (Fig. 6) on 10 August, and steamed $065^{\circ}$ to stream the geophysical gear. After streaming the gear, we returned to the beacon, passing it about 600 meters to the north on a heading of $245^{\circ}$. A course of $245^{\circ}$ was maintained for about 1 hour, and we turned to a course of $132^{\circ}$ at $1719 \mathrm{Z}$ and to $020^{\circ}$ at $1805 \mathrm{Z}$ in an attempt to pass over the beacon. This course took us west of Site 463 , and we missed by more than 2 miles. We continued on a course of $020^{\circ}$ for about 1 hour, and about $1940 \mathrm{Z}$ we turned to a new course for Site 464 . 

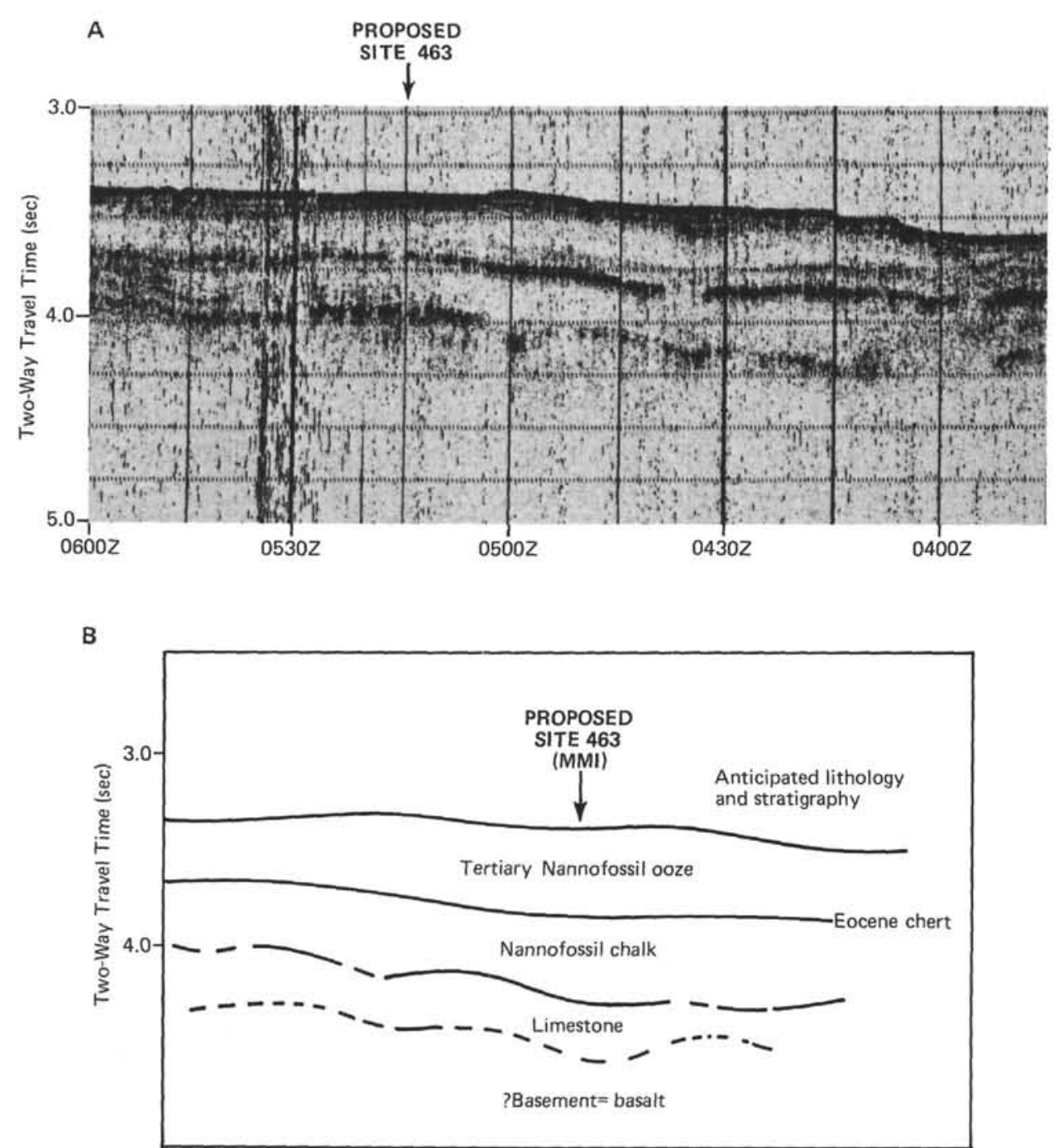

Figure 5. A. Mahi 7004 seismic-reflection profile across the northwest Mid-Pacific Mountains, showing the proposed location of Site 463. Figure 6 shows the Mahi 7004 track line. B. Provisional pre-drilling interpretations of possible lithologies and ages, based on the Mahi 7004 seismic-reflection profile.

\section{LITHOLOGIC SUMMARY}

\section{Lithologic Subdivision}

The sediment section at Site 463 is subdivided into four lithologic units, the uppermost being subdivided into two sub-units (Table 2). Divisions are based mainly on composition, diagenetic features, and sedimentary structures. Some of the basic sediment data obtained from this site are given in Appendices A through C. Complete tabulation of $\mathrm{CaCO}_{3}$ and organic-carbon contents are given in Dean (this volume).

\section{Sub-unit IA: Nannofossil Ooze (0-46.8 m)}

The sediment of this sub-unit is highly disturbed to soupy nannofossil ooze, dominantly very pale-brown (10YR $7 / 4,10 Y R \quad 7 / 3,10 Y R ~ 8 / 3)$, light-gray (10YR $7 / 2$ ), light-yellowish-brown (10YR 6/4), pale-brown (10YR 6/3), and white (10YR 8/2, 10YR 8/1). Mottles and burrows of similar lithology and color are common.
Most contacts in the section are gradational. A transition occurs over a 1-meter interval in Core 2 (7.5-8.5 $\mathrm{m})$, where the nannofossil assemblage increases to over $80 \%$ discoasters (Fig. 8). Discoasters remain abundant (80-98\% of all nannofossils) down to Core $4(29 \mathrm{~m})$. Below 34 meters in Core 4, discoasters constitute less than $30 \%$ of the nannofossil assemblage. Four small fragments of Eocene(?) chert, 1 to $4 \mathrm{~cm}$ in diameter, grayish-brown (10YR 5/2) and gray (N6), occur near the base of Unit IA at 44 to 45.5 meters.

The boundary between Sub-units IA and IB is in Section 3 of Core 7, at 46.8 meters sub-bottom. It is easily distinguished by a color change from brownish-white (10YR 8/2) above to stark white (lighter than 10Y 8/1) below a sharp but disturbed contact. The first appearance of discoasters in the section, and the change from predominant chalk below to ooze above, occurs at this boundary. It also marks an early Eocene to early Maastrichtian hiatus. 


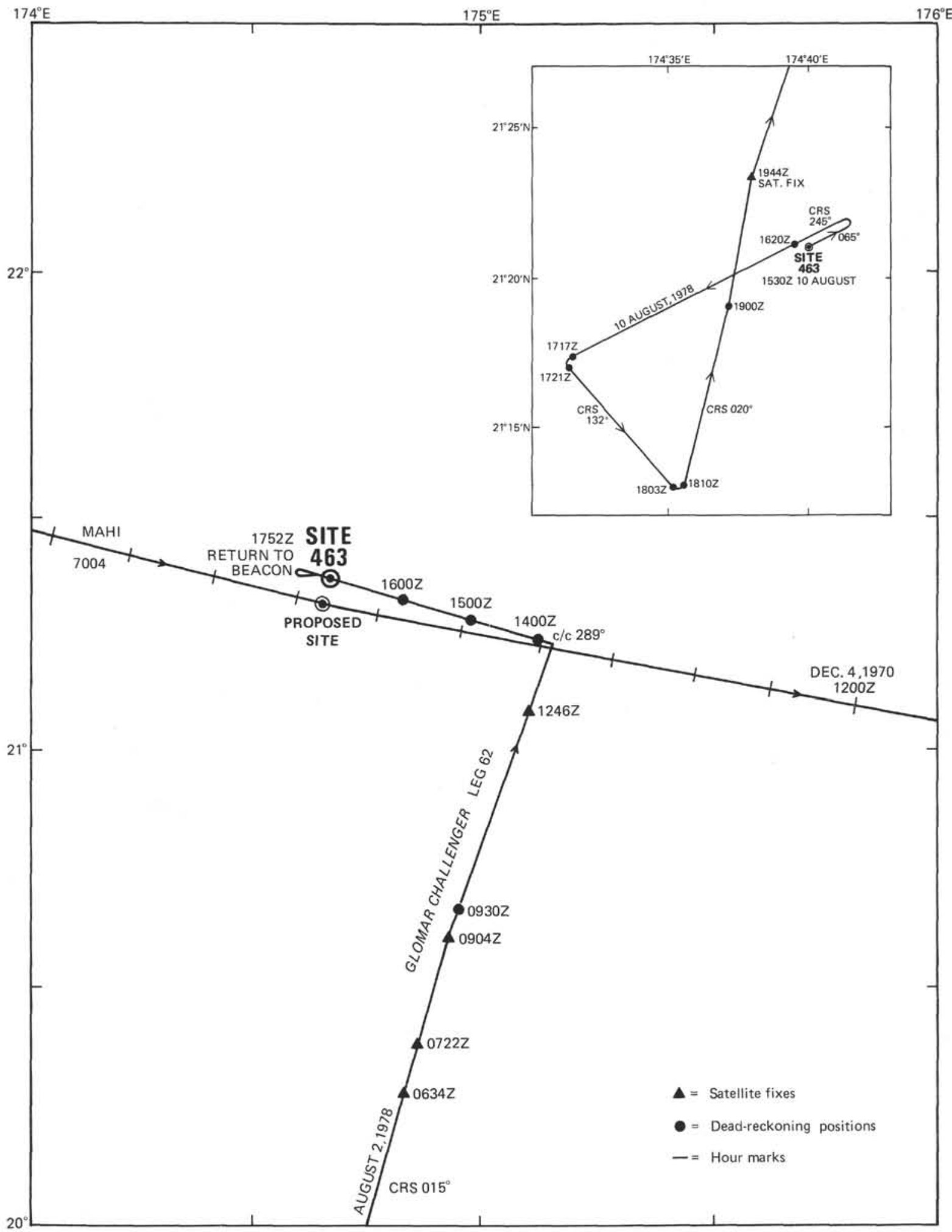

Figure 6. Chart of the Mahi profile and of the Glomar Challenger Leg 62 track line approaching Site 463. Insert shows the Glomar Challenger track line leaving Site 463. 


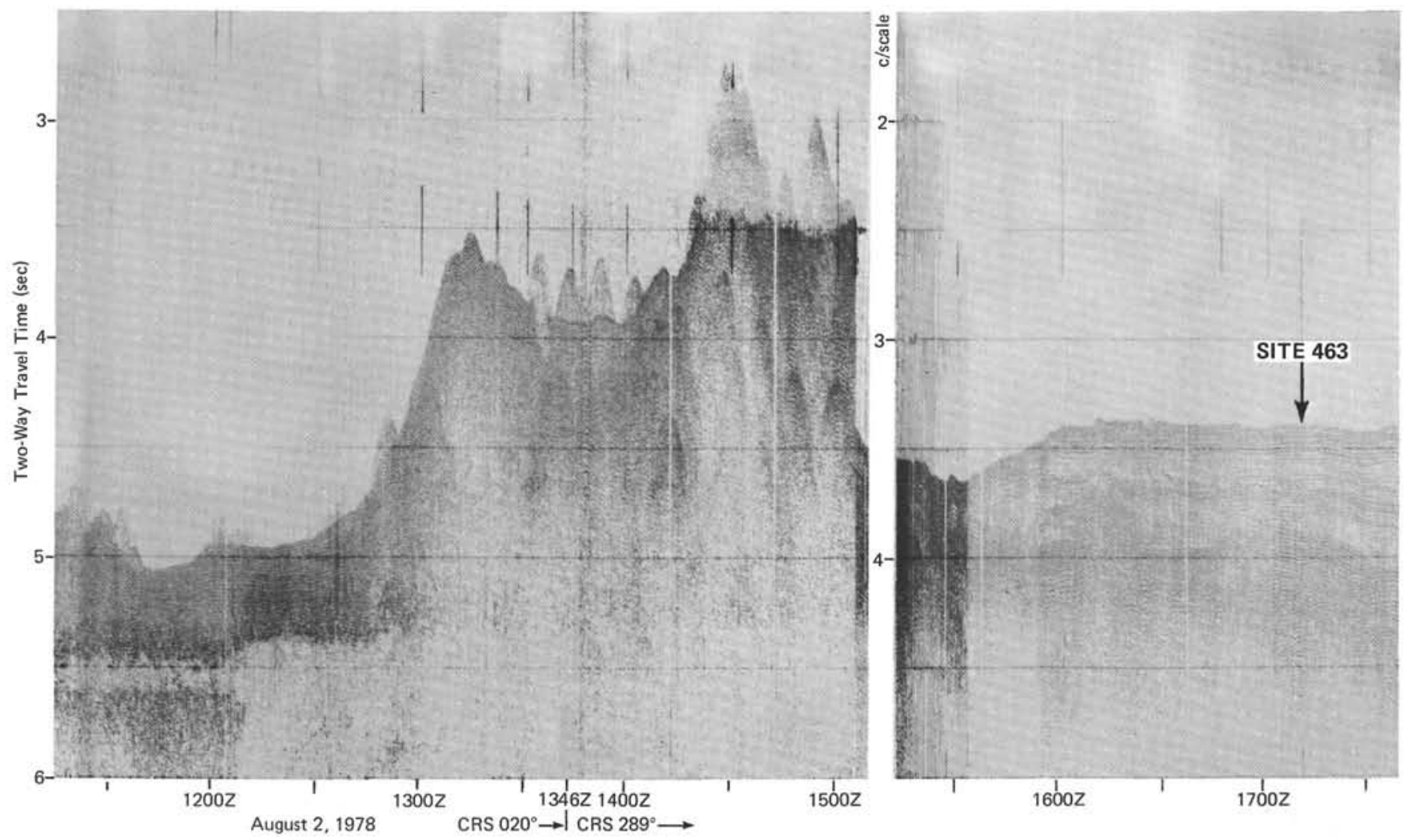

Figure 7. Glomar Challenger Leg 62 seismic-reflection profile made during the approach to Site 463.

\section{Sub-unit IB: Foraminifer Nannofossil Chalk and Nannofossil Foraminifer Chalk (46.8-452 m)}

The chalk is characterized by its very stark white color (10YR 8/1, N8, 2.5Y 8/1, and lighter shades). An exception is the interval in Cores 26 and 27 from 219 to 226.5 meters, which is pinkish-gray $(7.5 \mathrm{YR} 7 / 2,7.5 \mathrm{YR}$ $7 / 3$ ) and pink (7.5YR 8/4). The chalk in the upper part of Unit IB is very uniform (no mottling or bedding). Faint greenish laminations appear in Core 21, in three 2to $3-\mathrm{cm}$ intervals. Mottling, burrows, and laminations are more common in Core 27 and below, but for the most part the chalk is uniform and shows no structures. In many intervals, a soupy, highly disturbed sediment is encountered; it appears to be formed largely by drilling disturbance of a poorly lithified chalk. We have described these soupy intervals as "ooze," even though we have some reservations about use of this term.

The composition of the chalk varies down-section. At the boundary with Sub-unit IA, foraminifers constitute less than $10 \%$ of the smear-slide components (Appendix A). Planktonic foraminifers are abundant in the $>63$ $\mathrm{mm}$ size fractions (Appendix B). Their abundance increases to over $30 \%$ in Core 11 , and remains high through Core 15; it then becomes variable, usually less than $20 \%$, throughout the remainder of Sub-unit IB.
Thus, the compositional range of nannofossil chalk to foraminifer nannofossil chalk to nannofossil foraminifer chalk is present in this sub-unit.

Chert, a common component of Sub-unit IB, occurs for the most part as drilling fragments within the soupy sections, and as "drilling biscuits" within the moreindurated chalk intervals (Hein et al., this volume). It is highly variable in color, showing various shades of red, brown, yellow, gray, and black. Some of the gray chert is banded and burrow-mottled. Silicified chalk is closely associated with the chert in Cores $30,31,32,33$, and 42; because of its hardness, it may appear to be limestone. White porcellanite commonly is observed as rims on the chert.

The transition between Sub-unit IB and Unit II occurs at about 452 meters. Unfortunately, Core 51 (442.5$452 \mathrm{~m}$ ) consists of only a few chert fragments and cannot be used to determine precisely the boundary. Core 50 belongs in Sub-unit IB, and Core 52 belongs in Unit II; the boundary between the two units arbitrarily has been placed at the bottom of Core 51 . The boundary marks the transition from chalk to limestone (except for the silicified limestones described from Sub-unit IB), which can also be observed as a change from strongly recrystallized carbonate (identified as "carbonate unspecified" in Appendix A) to unrecrystallized nannofos- 
Table 1. Site 463 coring summary.

\begin{tabular}{|c|c|c|c|c|}
\hline $\begin{array}{l}\text { Core } \\
\text { No. }\end{array}$ & $\begin{array}{l}\text { Date } \\
\text { (Aug } \\
1978 \text { ) }\end{array}$ & $\begin{array}{c}\text { Time } \\
\text { (L) }\end{array}$ & $\begin{array}{l}\text { Depth From } \\
\text { Drill Floor } \\
\text { (m) } \\
\text { Top Bottom }\end{array}$ & $\begin{array}{l}\text { Depth Below } \\
\text { Sea Floor } \\
\text { (m) } \\
\text { Top Bottom }\end{array}$ \\
\hline 1 & 3 & 1439 & $2532.0-2537.5$ & $0.0-5.5$ \\
\hline 2 & 3 & 1533 & $2537.5-2547.0$ & $5.5-15.0$ \\
\hline 3 & 3 & 1616 & $2547.0-2556.5$ & $15.0-24.5$ \\
\hline 4 & 3 & 1704 & $2556.5-2566.0$ & $24.5-34.0$ \\
\hline 5 & 3 & 1852 & $2566.0-2570.0$ & $34.0-38.0$ \\
\hline 6 & 3 & 1947 & $2570.0-2575.5$ & $38.0-43.5$ \\
\hline 7 & 3 & 2041 & $2575.5-2585.0$ & $43.5-53.0$ \\
\hline 8 & 3 & 2146 & $2585.0-2594.5$ & $53.0-62.5$ \\
\hline 9 & 3 & 2234 & $2594.5-2604.0$ & $62.5-72.0$ \\
\hline 10 & 3 & 2333 & $2604.0-2613.5$ & $72.0-81.5$ \\
\hline 11 & 4 & 0047 & $2613.5-2623.0$ & $81.5-91.0$ \\
\hline 12 & 4 & 0144 & $2623.0-2632.5$ & $91.0-100.5$ \\
\hline 13 & 4 & 0247 & $2632.5-2642.0$ & $100.5-110.0$ \\
\hline 14 & 4 & 0345 & $2642.0-2651.5$ & $110.0-119.5$ \\
\hline 15 & 4 & 0448 & $2651.5-2661.0$ & $119.5-129.0$ \\
\hline 16 & 4 & 0540 & $2661.0-2670.5$ & $129.0-138.5$ \\
\hline 17 & 4 & 0649 & $2670.5-2680.0$ & $138.5-148.0$ \\
\hline 18 & 4 & 0744 & $2680.0-2689.5$ & $148.0-157.5$ \\
\hline 19 & 4 & 0847 & $2689.5-2699.0$ & $157.5-167.0$ \\
\hline 20 & 4 & 0950 & $2699.0-2708.5$ & $167.0-176.5$ \\
\hline 21 & 4 & 1044 & $2708.5-2718.0$ & $176.5-186.0$ \\
\hline 22 & 4 & 1146 & $2718.0-2727.5$ & $186.0-195.5$ \\
\hline 23 & 4 & 1245 & $2727.5-2731.5$ & $195.5-199.5$ \\
\hline 24 & 4 & 1338 & $2731.5-2737.0$ & $199.5-205.0$ \\
\hline 25 & 4 & 1436 & $2737.0-2746.5$ & $205.0-214.5$ \\
\hline 26 & 4 & 1528 & $2746.5-2756.0$ & $214.5-224.0$ \\
\hline 27 & 4 & 1640 & $2756.0-2765.5$ & $224.0-233.5$ \\
\hline 28 & 4 & 1746 & $2765.5-2775.0$ & $233.5-243.0$ \\
\hline 29 & 4 & 1848 & $2775.0-2784.5$ & $243.0-252.5$ \\
\hline 30 & 4 & 2005 & $2784.5-2794.0$ & $252.5-262.0$ \\
\hline 31 & 4 & 2115 & $2794.0-2803.5$ & $262.0-271.5$ \\
\hline 32 & 4 & 2212 & $2803.5-2813.0$ & $271.5-281.0$ \\
\hline 33 & 4 & 2316 & $2813.0-2822.5$ & $281.0-290.5$ \\
\hline 34 & 5 & 0020 & $2822.5-2832.0$ & $290.5-300.0$ \\
\hline 35 & 5 & 0137 & $2832.0-2841.5$ & $300.0-309.5$ \\
\hline 36 & 5 & 0314 & $2841.5-2851.0$ & $309.5-319.0$ \\
\hline 37 & 5 & 0427 & $2851.0-2860.5$ & $319.0-328.5$ \\
\hline 38 & 5 & 0526 & $2860.5-2870.0$ & $328.5-338.0$ \\
\hline 39 & 5 & 0636 & $2870.0-2879.5$ & $338.0-347.5$ \\
\hline 40 & 5 & 0849 & $2879.5-2889.0$ & $347.5-357.0$ \\
\hline 41 & 5 & 0952 & $2889.0-2898.5$ & $357.0-366.5$ \\
\hline 42 & 5 & 1103 & $2898.5-2908.0$ & $366.5-376.0$ \\
\hline 43 & 5 & 1216 & $2908.0-2917.5$ & $376.0-385.5$ \\
\hline 44 & 5 & 1319 & $2917.5-2927.0$ & $385.5-395.0$ \\
\hline 45 & 5 & 1421 & $2927.0-2936.5$ & $395.0-404.5$ \\
\hline 46 & 5 & 1525 & $2936.5-2946.0$ & $404.5-414.0$ \\
\hline 47 & 5 & 1631 & $2946.0-2955.5$ & $414.0-423.5$ \\
\hline 48 & 5 & 1859 & $2955.5-2959.5$ & $423.5-427.5$ \\
\hline 49 & 5 & 2049 & $2959.5-2965.0$ & $427.5-433.0$ \\
\hline 50 & 5 & 2200 & $2965.0-2974.5$ & $433.0-442.5$ \\
\hline 51 & 5 & 2300 & $2974.5-2984.0$ & $442.5-452.0$ \\
\hline 52 & 6 & 0024 & $2984.0-2993.5$ & $452.0-461.5$ \\
\hline 53 & 6 & 0212 & $2993.5-3003.0$ & $461.5-471.0$ \\
\hline 54 & 6 & 0406 & $3003.0-3012.5$ & $471.0-480.5$ \\
\hline 55 & 6 & 0530 & $3012.5-3022.0$ & $480.5-490.0$ \\
\hline 56 & 6 & 0732 & $3022.0-3031.5$ & $490.0-499.5$ \\
\hline 57 & 6 & 0944 & $3031.5-3041.0$ & $499.5-509.0$ \\
\hline 58 & 6 & 1255 & $3041.0-3050.5$ & $509.0-518.5$ \\
\hline 59 & 6 & 1627 & $3050.5-3060.0$ & $518.5-528.0$ \\
\hline 60 & 6 & 2005 & $3060.0-3067.5$ & $528.0-535.5$ \\
\hline 61 & 6 & 2207 & $3067.5-3069.5$ & $535.5-537.5$ \\
\hline 62 & 7 & 0102 & $3069.5-3079.0$ & $537.5-547.0$ \\
\hline 63 & 7 & 0328 & $3079.0-3088.5$ & $547.0-556.5$ \\
\hline 64 & 7 & 0600 & $3088.5-3098.0$ & $556.5-566.0$ \\
\hline 65 & 7 & 0820 & $3098.0-3107.5$ & $566.0-575.5$ \\
\hline 66 & 7 & 1138 & $3107.5-3117.0$ & $575.5-585.0$ \\
\hline 67 & 7 & 1345 & $3117.0-3126.5$ & $585.0-594.5$ \\
\hline 68 & 7 & 1551 & $3126.5-3136.0$ & $594.5-604.0$ \\
\hline 69 & 7 & 1927 & $3136.0-3145.5$ & $604.0-613.5$ \\
\hline 70 & 7 & 2355 & $3145.5-3155.0$ & $613.5-623.0$ \\
\hline 71 & 8 & 0358 & $3155.0-3164.5$ & $623.0-632.5$ \\
\hline 72 & 8 & 0813 & $3164.5-3174.0$ & $632.5-642.0$ \\
\hline 73 & 8 & 1336 & $3174.0-3183.5$ & $642.0-651.5$ \\
\hline 74 & 8 & 1654 & $3183.5-3193.0$ & $651.5-661.0$ \\
\hline 75 & 8 & 1855 & $3193.0-3202.5$ & $661.0-670.5$ \\
\hline 76 & 8 & 2149 & $3202.5-3212.0$ & $670.5-680.0$ \\
\hline 77 & 9 & 0027 & $3212.0-3221.5$ & $680.0-689.5$ \\
\hline 78 & 9 & 0244 & $3221.5-3231.0$ & $689.5-699.0$ \\
\hline 79 & 9 & 0430 & $3231.0-3240.5$ & $699.0-708.5$ \\
\hline 80 & 9 & 0706 & $3240.5-3242.0$ & $708.5-710.5$ \\
\hline 81 & 9 & 1010 & $3242.5-3250.0$ & $710.5-718.0$ \\
\hline 82 & 9 & 1310 & $3250.0-3259.5$ & $718.0-727.5$ \\
\hline 83 & 9 & 1703 & $3259.5-3269.0$ & $727.5-737.0$ \\
\hline 84 & 9 & 1932 & $3269.0-3278.5$ & $737.0-746.5$ \\
\hline 85 & 9 & 2252 & $3278.5-3288.0$ & $746.5-756.0$ \\
\hline 86 & 10 & 0226 & $3288.0-3297.5$ & $756.0-765.5$ \\
\hline 87 & 10 & 0551 & $3297.5-3307.0$ & $765.5-775.0$ \\
\hline 88 & 10 & 0854 & $3307.0-3316.5$ & $775.0-784.5$ \\
\hline 89 & 10 & 1200 & $3316.5-3326.0$ & $784.5-794.0$ \\
\hline 90 & 10 & 1522 & $3326.0-3335.5$ & $794.0-803.5$ \\
\hline 91 & 10 & 1818 & $3335.5-3345.0$ & $803.5-813.0$ \\
\hline 92 & 10 & 2052 & $3345.0-3354.5$ & $813.0-822.5$ \\
\hline Total & & & & \\
\hline
\end{tabular}

sils and foraminifers. It also marks the transition from uniform, massive carbonates above to multicolored carbonates below.

\section{Unit II: Multicolored Limestone and Silicified Limestone (452-587.7 m)}

The sediment in this unit is characterized by limestone and silicified limestone showing cyclic color variation on the scale of about 1 to $20 \mathrm{~cm}$ (Fig. 9). Most of the carbonate is recrystallized, but nannofossils and foraminifers are still recognizable in most smear slides (Appendix A). An important diagenetic overprint of silicification occurs in Unit II, silica replacing up to $80 \%$ of some limestones. Silica contents range from about 10 to $80 \%$ in the silicified limestone.

Most intervals show common horizontal laminations and burrowing, although a few (generally those lightest in color) appear massive and uniform (Fig. 9). Burrows are distorted and flattened because of compaction (Fig. 9). For the most part, laminae appear wavy and may be either continuous or discontinuous across the core. The cyclic nature of the sediments may indicate that the sediments underwent a period of differential lithification, existing alternately as beds of ooze and chalk and (or) beds of chalk and limestone. This is shown by selective fracturing and plastic deformation observed in adjacent layers. Contacts between cycles may be either sharp or gradational, but most are gradational and burrowed.

Graded beds are present in Cores 56, 59, and 60 (e.g., Core 56, Section 1, 82-97 cm). The gradations are generally marked by a color change from dark at the base of the bed to light at the top. All the sediments in the graded beds appear to be pelagic; the upper parts of the graded beds are nannofossil limestone, whereas the bases are enriched in foraminifers and radiolarians. Cores $60,61,63,64,66$, and 67 have coarse layers (1-8 $\mathrm{cm}$ thick) enriched in radiolarians. Some of the coarse layers exhibit erosional basal contacts, but the layers appear to be uniform, coarse-grained intervals, rather than parts of graded units.

The colors of this cyclic unit are variable downsection. In Cores 52 through 55, the cycles are alternations of white limestone and pale-green or greenish-gray limestone. Cores 57 through 65 have cyclic color alternations of pink, green, brown, and white. Cores 66 and 67 consist of alternations of gray and green limestone. The coarse-grained, ungraded layers (previously described) are very pale brown (10YR 7/3) in Cores 60, 61, and 63 , and light greenish-gray ( $5 Y 7 / 1$ and $56 \mathrm{Y} 7 / 1)$ in the remainder of the cores in this unit.

Chert is a common component of Unit II and is found as drilling fragments, nodules, and larger layers (Hein et al., this volume). The chert is very similar in most respects, including the range of colors, to that described from Sub-unit IA.

The boundary between Units II and III is determined by the highest occurrence of ash beds as a common component of the sediments. There is one ash layer above the lower Unit II boundary in Core 62, but this appears to be an isolated occurrence. The boundary between the 
Table 2. Lithologic units at Site 463.

\begin{tabular}{llcccc}
\hline Unit & \multicolumn{1}{c}{ Lithology } & Cores & $\begin{array}{c}\text { Sub-bottom } \\
\text { Depth } \\
(\mathrm{m})\end{array}$ & $\begin{array}{c}\text { Thickness } \\
(\mathrm{m})\end{array}$ & \multicolumn{1}{c}{$\begin{array}{c}\text { Age } \\
(\mathrm{m} . \mathrm{y} .)\end{array}$} \\
\hline IA & Nannofossil ooze & $1-7$ & $0-46.8$ & 46.8 & $\begin{array}{l}\text { Pleistocene-e. Eocene } \\
(0-50)\end{array}$ \\
IB & $\begin{array}{l}\text { Foraminifer nannofossil chalk and } \\
\text { nannofossil foraminifer chalk }\end{array}$ & $7-51$ & $46.8-452$ & 405.2 & $\begin{array}{l}\text { E. Maastrichtian to } \\
\text { 1. Albian (67-103) }\end{array}$ \\
II & $52-67$ & $452.0-587.7$ & 135.7 & $\begin{array}{l}\text { M. Albian to e. Aptian } \\
\text { (103-112) }\end{array}$ \\
III $\begin{array}{l}\text { and silicified limestone } \\
\text { Tuffaceus and carbonaceous }\end{array}$ & $67-71$ & $587.7-632.5$ & 44.8 & $\begin{array}{l}\text { Early Aptian } \\
\text { (112-113) }\end{array}$ \\
IV $\begin{array}{l}\text { Intestone } \\
\text { limestone }\end{array}$ & $72-92$ & $632.5-822.5$ & 190.0 & $\begin{array}{l}\text { E. Aptian to } \\
\text { Barremian (113-117) }\end{array}$ \\
\hline
\end{tabular}
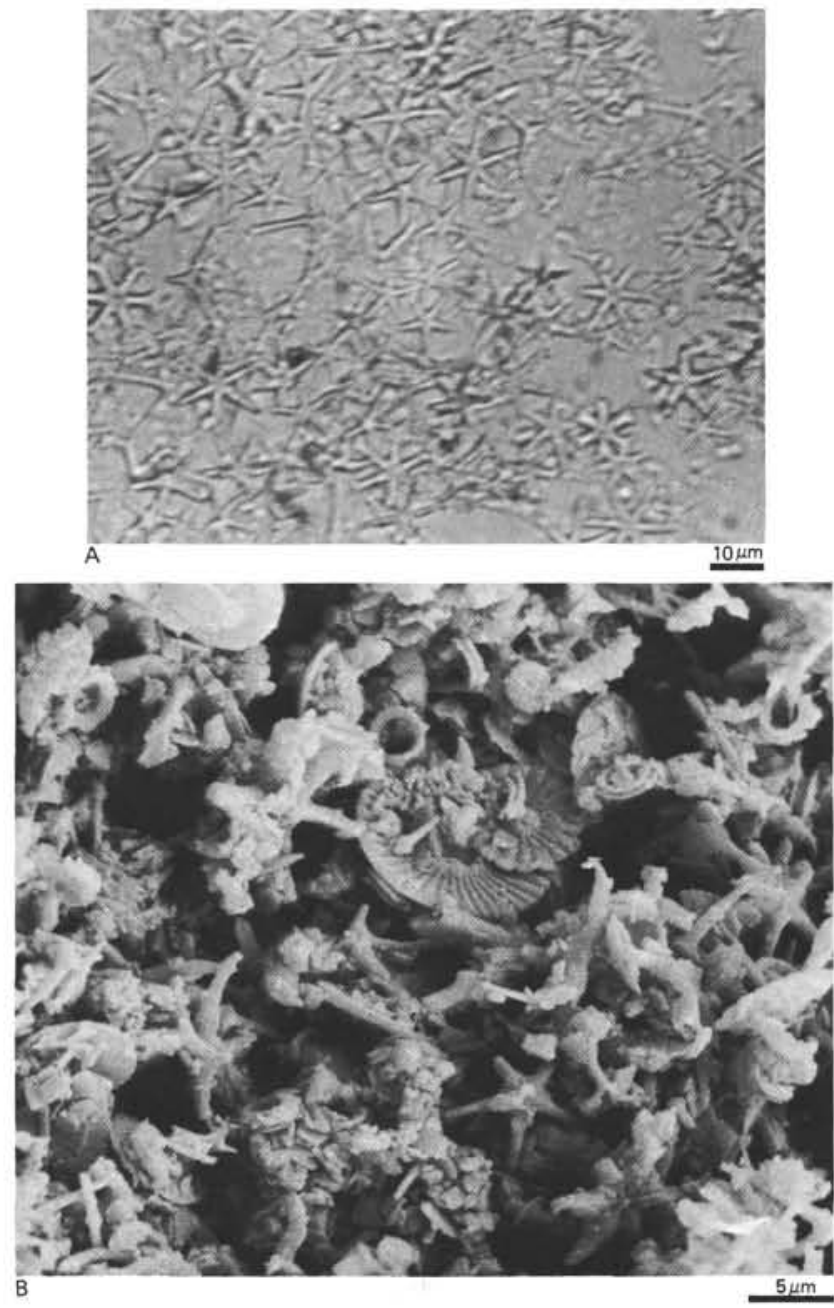

Figure 8. Pliocene discoaster ooze from Lithologic Unit IA. A. Plane light $(\times 80)$. B. SEM photomicrograph (bar scale $=5 \mu \mathrm{m} ; 463-2-5$, $100-101 \mathrm{~cm})$.

two units is placed at the top of the ash bed in Core 67, Section 2, at $73 \mathrm{~cm}$.

\section{Unit III: Tuffaceous and Carbonaceous Limestone (587.7-632.5 m)}

The distinguishing characteristics of this unit are the occurrence of ash beds and limestones enriched in ash and organic carbon. These appear within a sequence of

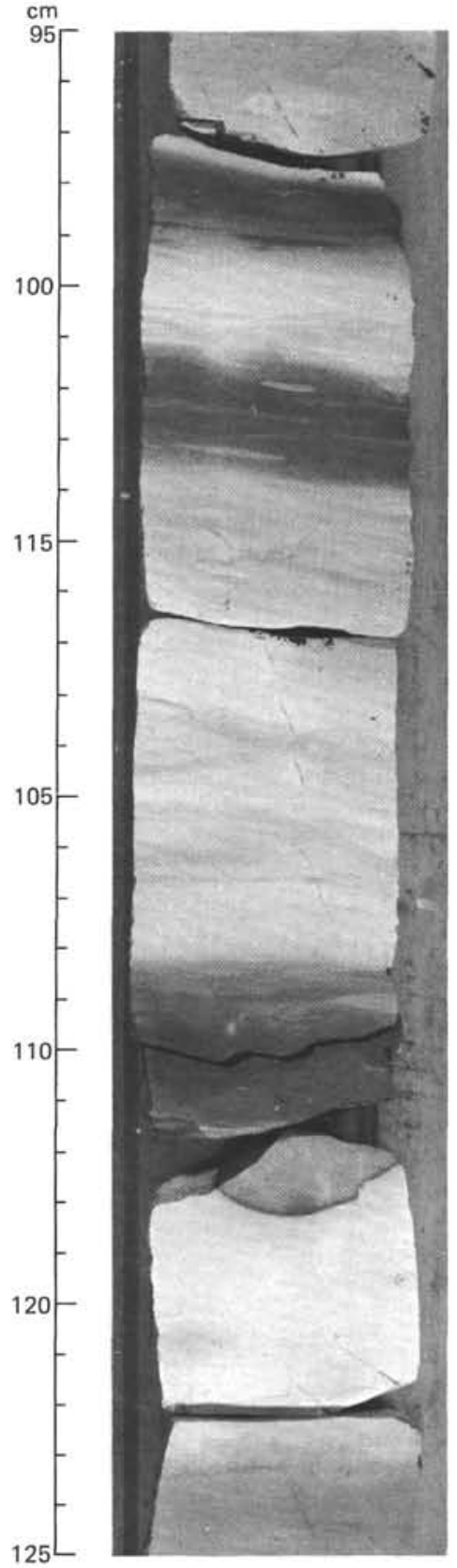

Figure 9. Sedimentary structures in the multicolored limestone of Lithologic Unit II (463-59-2, 95-125 cm). 
cyclic color alternations somewhat similar to those found in Unit II. The cycles are color variations of white, gray, and green, with darker beds of tuff and carbonaceous limestone, on the scale of 1 to $65 \mathrm{~cm}$. Tuff beds are greenish-black (56Y 2/1) and greenish-gray (5Y $6 / 1,5 \mathrm{G} \mathrm{4/1)}$; the carbonaceous limestone is olive-black (5Y $2 / 1)$ to greenish-black $(56 \mathrm{Y} 2 / 1)$, with organiccarbon concentrations to $>7 \%$ (Dean and Claypool, this volume). Intervals enriched in organic carbon are horizontally laminated, without any zones of disturbance or burrowing (Fig. 10). The lower contacts of the organic-carbon-rich beds are mostly gradational, and

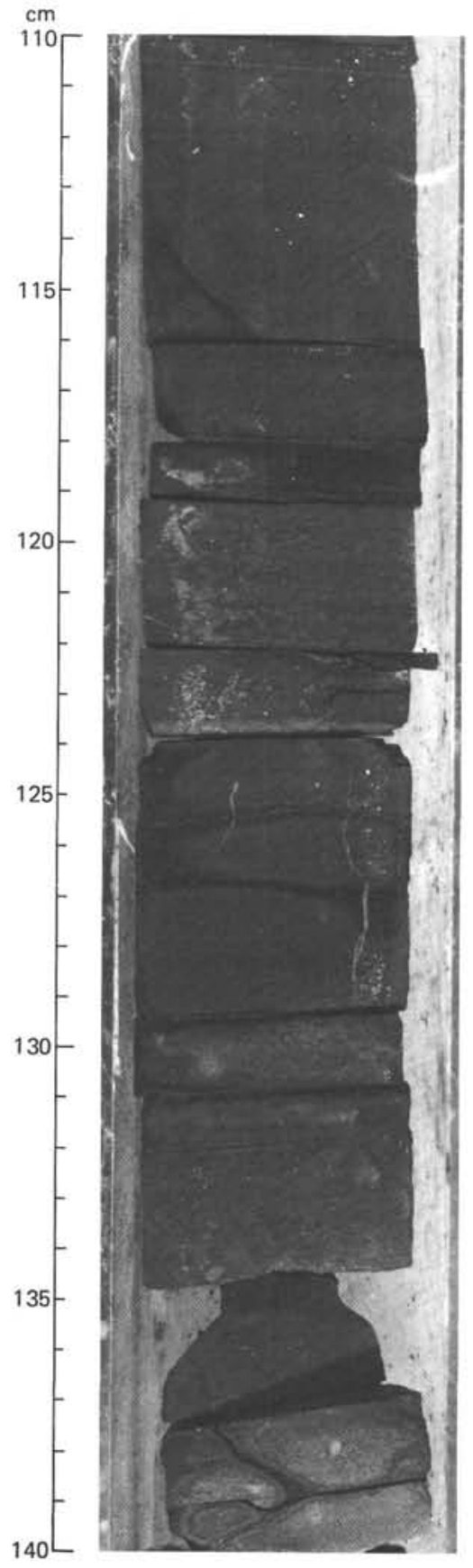

Figure 10. Sedimentary structures in the tuffaceous and carbonaceous limestones of Lithologic Unit III (463-70-5, 110-140 cm). the upper contacts are usually sharp, but exceptions are common. The highest concentration of organic carbon is in Core 70 .

The tuff (ash) beds commonly have horizontal laminations, but several are massive (Vallier and Jefferson, this volume; Hein and Vanek, this volume). The top and bottom contacts of the tuff beds may be sharp or gradational. Most gradational contacts are bioturbated.

The lighter-colored beds in Unit III (those without high concentrations of organic carbon or ash) are usually burrowed and have wavy laminations. The upper and lower contacts of these beds usually are gradational. Chert, is common as fragments and layers within Unit III. Most of this chert is various shades of gray, although some dark-reddish-brown chert is present.

The boundary between Units III and IV, at the bottom of Core 71 , is marked by the disappearance of ash beds as a common component of the sediment.

\section{Unit IV: Interbedded Pelagic and Clastic Limestone (632.5-822.5 m)}

This unit consists of pelagic limestones and marlstones interbedded with clastic, mostly calcareous turbidite and debris-flow deposits. The amount of clastic sediments increases down-section through Core 89. Cores 90 to 92 do not contain clastic limestone, but this may be the result of selective recovery of the pelagic limestone; these three cores recovered less than $60 \mathrm{~cm}$ of a total of 28.5 meters cored.

The upper part of Unit IV (Cores 72-74) shows cyclic color alternations of various shades of olive, green, and white, similar to those in Units II and III. Burrowing, wispy discontinuous laminae, and streaks are common. Most contacts are burrowed and gradational, but those at the bases of redeposited beds are sharp. The first two clastic turbidites, encountered going down-section occur in Core 73 ; they are pale-olive (5Y 6/2) and gray (5Y $6 / 1$ ) and are composed of granule-size and smaller clasts of carbonate, pyrite, glauconite, and quartz.

In the remaining cores (75-92), the dominant pelagic component is light-gray and white limestone, with dark and contorted laminations (Fig. 11) some of which are stylolitic seams. Clastic limestones are interbedded with the pelagic limestones. Some of the clastic beds are turbidites similar to those described above, but most are massive beds with rounded clasts showing little or no gradation in grain size. There is an overall trend for the maximum size of clasts to increase with increasing depth in the section (Figure 12). The clast sizes range from less than $1 \mathrm{~mm}$ to several centimeters in diameter; the clasts are in a silt- and clay-sized matrix. These massive clastic units first appear in Core 80, and are common through Core 89 . Typical clasts within these massive beds consist of fine-grained limestones, oolites, echinoderm and mollusk fragments, glauconite, quartz, stromatolite fragments, and basalt(?) chips (Fig. 13). The massive intervals of clastic sediment have a yellow-gray (5Y 7/1) groundmass, the largest clasts being white (5Y $8 / 1)$, rounded, fine-grained limestone.

A few marlstone beds, generally showing fine bedding and laminations, are also present in Unit IV. These 


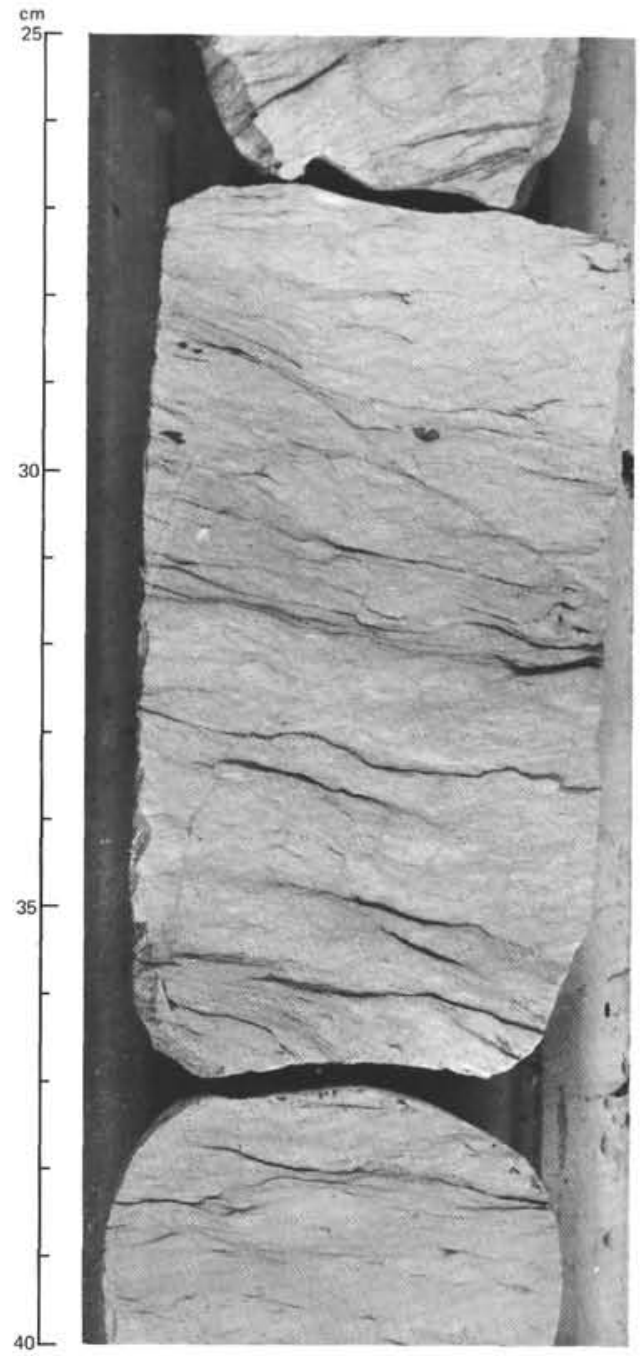

Figure 11. Pelagic limestone with contorted laminations from the interbedded clastic and pelagic limestones of Lithologic Unit IV (463-77-1, 25-40 cm).

are dark greenish-gray (56 4/1) and appear to be pelagic.

\section{Conclusions}

Site 463 contains an incomplete record of sedimentation and dissolution from the earliest Barremian to $\mathrm{Re}$ cent. Middle Miocene to late Oligocene, late Oligocene to late Eocene, early Eocene to early Maastrichtian and Campanian to Santonian hiatuses are the only important interruptions in the record. The site has remained well above the CCD throughout its history. Important aspects of the sediments recovered at Site 463 are:

1) Sediments of late Pliocene to late Miocene age (8.5-29 m) are nannofossil ooze; discoasters comprise 80 to $98 \%$ of the nannofossil assemblage. This is probably the result of increased discoaster productivity, as well as selective dissolution of coccoliths.

2) The hiatuses at this site are essentially the same as those at Site 171 on Horizon Guyot, but different from those at Site 313 in the eastern Mid-Pacific Mountains.

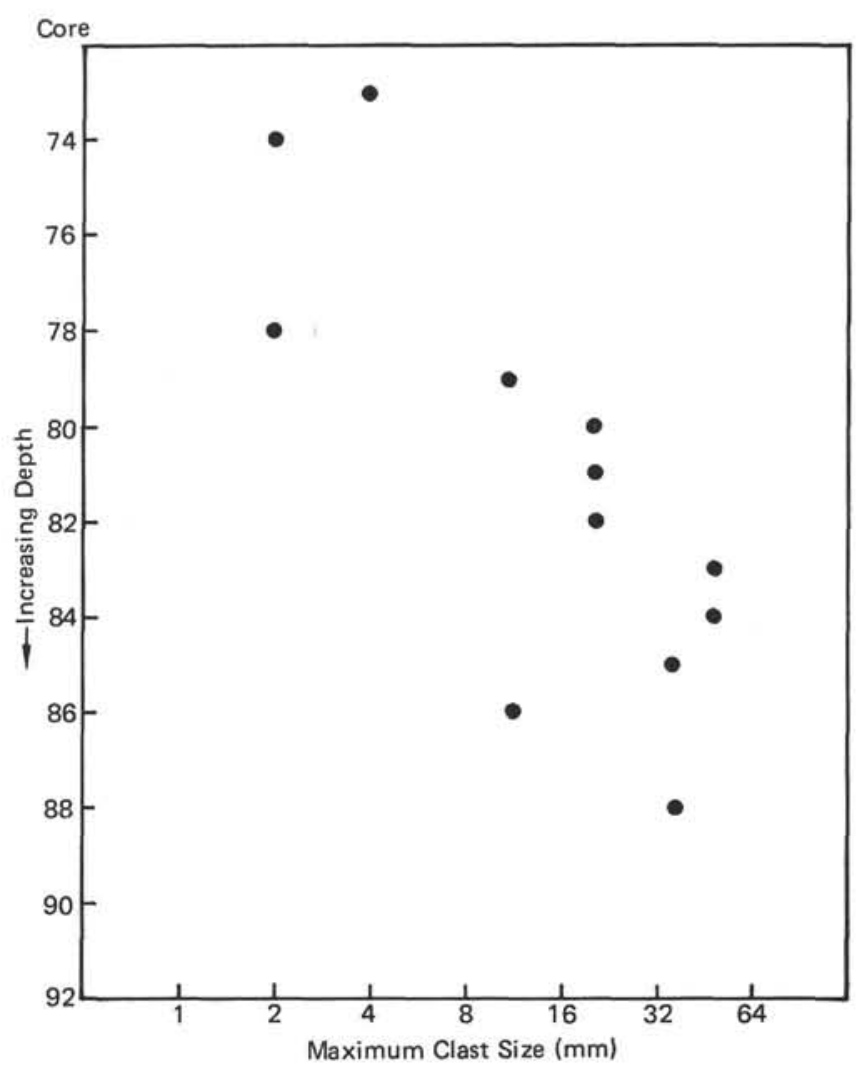

Figure 12. Variation in maximum clast size as a function of sub-bottom depth, Lithologic Unit IV.

3) A thick middle to Upper Cretaceous section provides an excellent record of sedimentation. A very high rate of sedimentation in the early Maastrichtian to late Campanian $(\sim 42 \mathrm{~m} / \mathrm{m} . \mathrm{y}$.) marks the estimated time of equatorial crossing.

4) Cyclic alternations of multicolored limestones overlying carbonaceous limestones of early Aptian age at this site are similar to cyclic multicolored lithologies which overlie anoxic sedimentary sequences of the same age in the Atlantic. Tuffaceous sediments, recording a period of high volcanic-ash deposition, are interbedded with the carbonaceous limestones.

5) The oldest unit in the stratigraphic sequence at Site 463-the interbedded shallow-water clastic limestone and pelagic limestone-probably represents the shallowest depositional environment. Progressively younger sediments were deposited in progressively deeper water as the site subsided.

The sedimentation history at Site 463 can be summarized briefly as follows. During late Barremian time, the site was close to an oceanic volcanic island which apparently was associated with shallow-water carbonate banks. Existence of the shallow-water carbonates is documented by the presence of displaced stromatolites, oolites, and fragments of echinoderms and large mollusks in the clastic limestone beds of Unit IV (Fig. 13).

As the volcanic basement subsided, shallow-water sediments were redeposited at intermediate depths, forming clastic-limestone layers interbedded with pelagic 

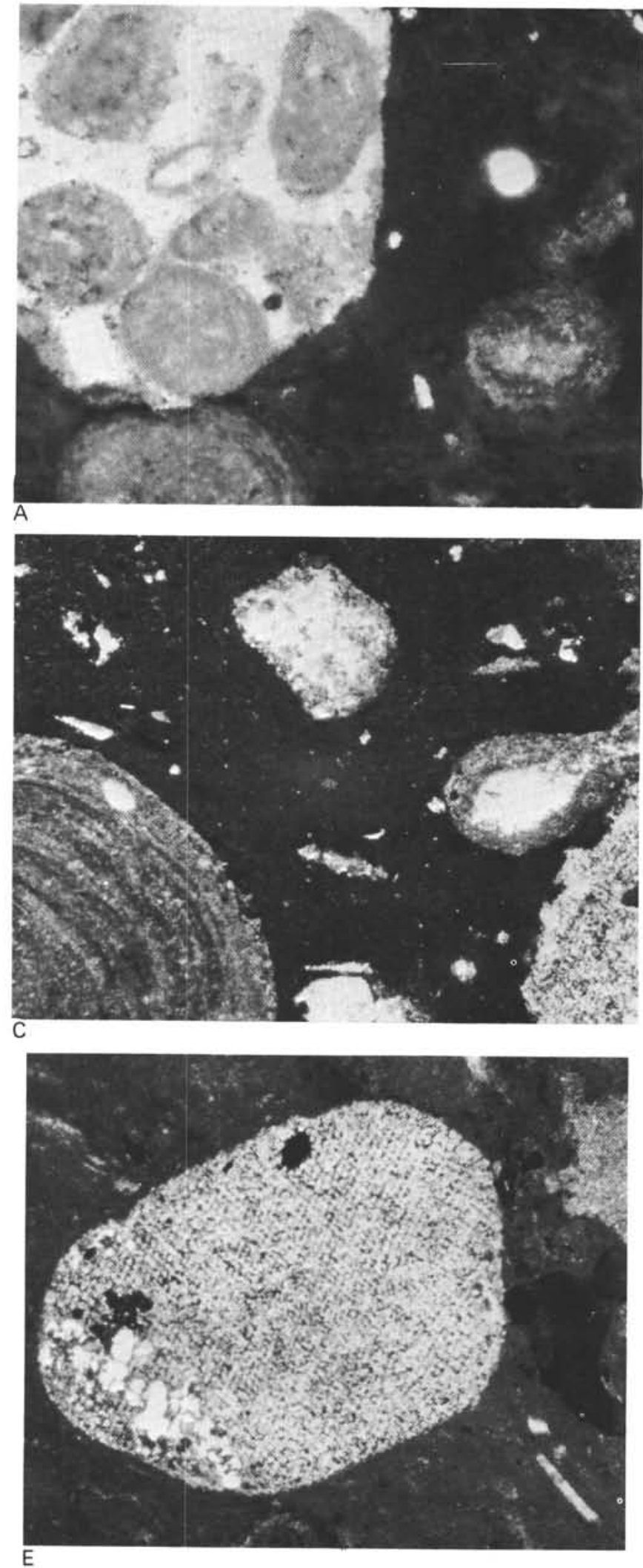

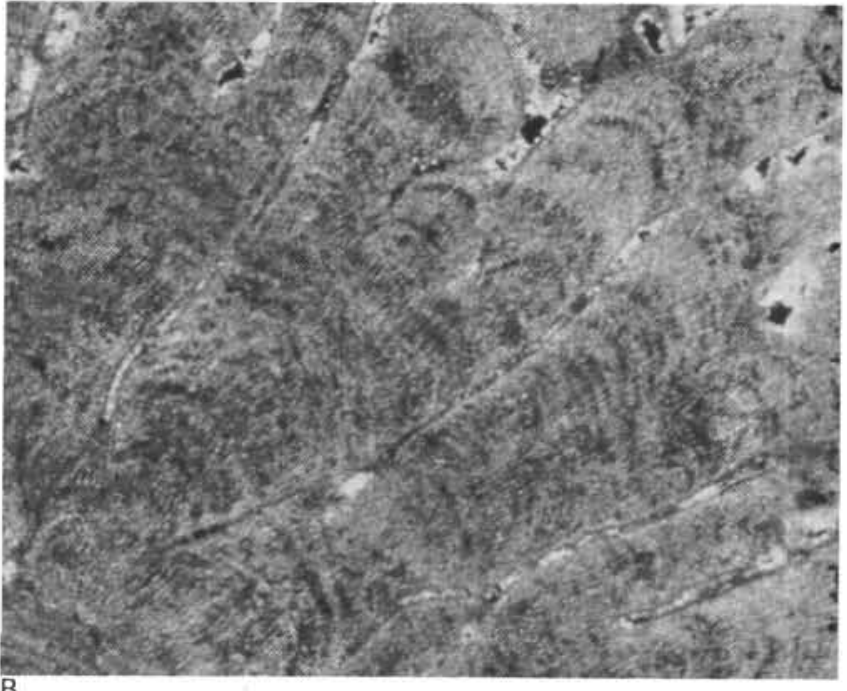

B

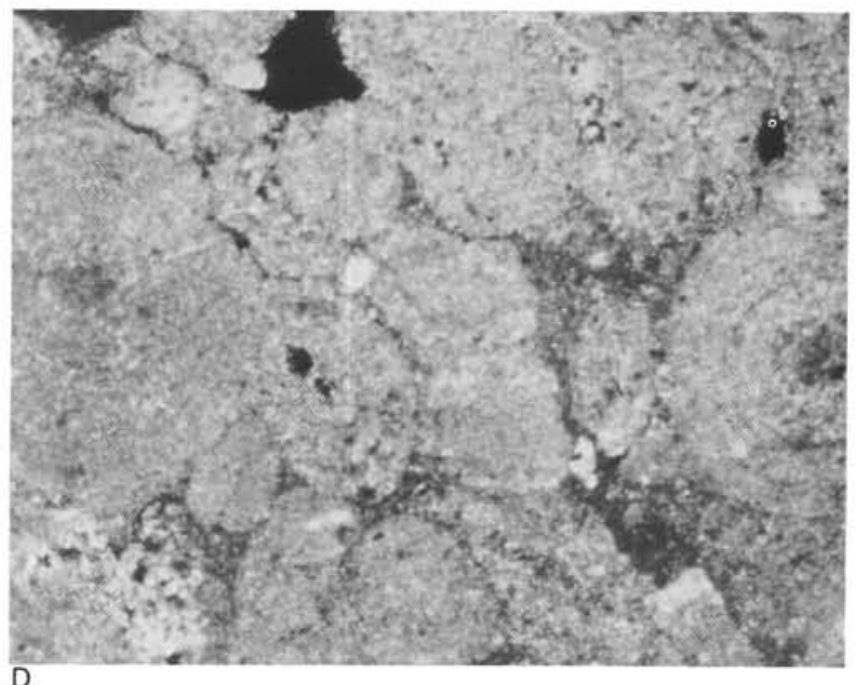

D

Figure 13. Carbonate clasts from Lithologic Unit IV (bar $=1 \mathrm{~mm}$; all cross-polarized light). A. 80-1, 9-11 cm (709.5 m). Oolites and a clast of oosparite in a micritic calcite matrix. B. $85-2,136-138 \mathrm{~cm}(749.5 \mathrm{~m})$. Part of a stromatolite fragment. C. $85-1,76-78 \mathrm{~cm}(747.3 \mathrm{~m})$. Oolites in a matrix of micrite and sparry calcite cement. D. 85-1, 59-61 cm $(747.1 \mathrm{~m})$. Part of a large oolite. Fossil fragments and other calcite debris "floating" in a matrix of micritic calcite. E. $84-1,20-22 \mathrm{~cm}(737.2 \mathrm{~m})$. Fossil fragment with reticulate pattern, partly replaced by $\mathrm{SiO}_{2}$, in a matrix of micritic calcite. 
limestones (Unit IV, Barremian to early Aptian). The pelagic limestones and the lack of a diverse benthicmollusk fauna suggest that water depth must have been greater than wave base (greater than about $200 \mathrm{~m}$ ). Continued subsidence during deposition of Unit IV is indicated by a decrease in the maximum size of clasts within the clastic limestone in progressively younger sediments (Fig. 12). Most of the massive redeposited beds, which are up to 1 meter thick, show little or no grain-size grading. This lack of grading tends to rule out turbidity currents as a mode of transport of the shallowwater clasts. The lack of size gradation and roundness of the clasts suggests transport by debris flows, which in turn suggests relatively short distances of transport. The uppermost clastic bed in this unit is a granule-size carbonate turbidite in Core 73. The younger carbonate sediments are entirely pelagic.

Shortly after deposition of the last clastic carbonate beds in the early Aptian, the sedimentary sequence at Site 463 was marked by a sudden influx of relatively large volumes of volcanic ash, indicating nearby volcanic activity. Volcanic activity lasted approximately 1 m.y. (the time represented by Unit III). The presence of volcanic ash is coincident with carbonaceous limestone (organic-carbon content of as much as $7 \%$ by weight), which indicates sediment accumulation under reducing conditions. Whether the association of volcanic ash and organic matter is fortuitous or causal is not known.

The multicolored limestone of Unit II was deposited from the early Aptian to the late Albian. The association of carbonaceous sediments underlying multicolored (green, gray, pink, and red) cyclic sediments is known from a number of sites in the Atlantic (e.g., Sites 105 and 367) and is almost exactly repeated at Site 463, although multicolored sediments are somewhat younger in the Atlantic (Late Cretaceous). The significance of this relationship is not known.

The remainder of the Cretaceous sediments is represented dominantly by foraminifer nannofossil ooze and chalk, with well-preserved microfossils. This suggests that the sediments were deposited above (or near) the Cretaceous lysocline. High sedimentation rates characterize the strata of the early Maastrichtian, a time when the site apparently crossed the equatorial zone of high productivity.

Accumulation of sediment during the Cenozoic was much reduced in comparison to the Cretaceous. Approximately $35 \mathrm{~m} . y$. of the Cenozoic record is missing, and the pre-Pliocene record which is present has an average accumulation rate of only $1.0 \mathrm{~m} / \mathrm{m} . \mathrm{y}$. The dominant sediment type is nannofossil ooze with moderate to good preservation of microfossils, suggesting deposition between the lysocline and the CCD.

Carbonate diagenesis at Site 463 reflects the normal progression of ooze to chalk to limestone. The transition from ooze to chalk occurs across the early Eocene to Maastrichtian hiatus and, because of poor recovery of sediment near the hiatus, is not fully documented. The upper part of Unit II shows chalk alternating with ooze, the degree of lithification increasing progressively to the bottom of the unit. The transition from chalk to limestone is not well documented, because of a high abundance of chert in that interval and poor core recovery. A diagenetic trend is apparent in the wispy and wavy laminations, which become progressively darker and better defined with depth, and eventually develop into thin, dark stylolitic seams. This suggests that pressure solution, due to increasing burial, selectively occurs within these laminae, ultimately forming the stylolitic seams.

Replacement of $\mathrm{CaCO}_{3}$ by $\mathrm{SiO}_{2}$, filling of voids by $\mathrm{SiO}_{2}$, and recrystallization of radiolarians are common phenomena in Units IB to IV. The general sequence of silicification (Fig. 14) appears to be as follows:

1) The chambers of foraminifers are partly to completely filled with $\mathrm{SiO}_{2}$.

2) The chambers of foraminifers are filled with $\mathrm{SiO}_{2}$, radiolarians are recrystallized, and some of the $\mathrm{CaCO}_{3}$ matrix is replaced by $\mathrm{SiO}_{2}$.

3) The matrix is completely replaced by $\mathrm{SiO}_{2}$, leaving only the test walls of foraminifers as $\mathrm{CaCO}_{3}$.

4) Complete replacement of $\mathrm{CaCO}_{3}$ by $\mathrm{SiO}_{2}$, and formation of chert.

\section{INTERSTITIAL-WATER GEOCHEMISTRY}

Results of shipboard measurements of $p \mathrm{H}$, alkalinity, salinity, calcium, magnesium, and chlorinity, in interstitial water from seven whole-core sediment samples are presented in Figure 15. Values of $p \mathrm{H}$ are low relative to surface sea water, ranging from 8.0 in the first core to 6.76 in Core 43, Section 3, 94-100 cm. Both $p \mathrm{H}$ and alkalinity are largely controlled by bacterial production of $\mathrm{CO}_{2}$ and equilibrium with carbonate minerals. Because of the high carbonate content of the sediments at Site 463 , the interstitial waters are probably close to saturation with respect to $\mathrm{CaCO}_{3}$, as $\mathrm{CaCO}_{3}$ is dissolved to offset $\mathrm{CO}_{2}$ produced by bacterial activity. As a result, alkalinity remains relatively constant with depth, whereas the calcium concentration increases markedly with depth (Fig. 15). An increase in calcium-ion concentration in interstitial waters commonly is observed in carbonate-rich deep-sea sediments, particularly in areas with rapid rates of sediment accumulation, and is attributed to dissolution of $\mathrm{CaCO}_{3}$ at depth (Sayles and others, 1973).

At Site 463 , the increase in calcium with depth is almost matched by a decrease in magnesium; this inverse relationship might imply formation of dolomite, although none was observed in smear slides of the sediments. Salinity and chlorinity show little variation from normal surface sea water, both increasing slightly with depth (Fig. 15).

The greatest change in interstitial-water chemistry appears to occur below 225 meters sub-bottom (Fig. 15). Unfortunately, poor recovery prohibited collection of interstitial water between Cores 27 and 43 to better define these changes. This zone of change is indicated by increases in salinity, chlorinity, and calcium, and by decreases in $p \mathrm{H}$ and magnesium; calcium shows the greatest change. There is no apparent change in the sediments that would indicate an increase in rate of dissolution of $\mathrm{CaCO}_{3}$ between 225 and 480 meters. 


\section{PHYSICAL PROPERTIES}

The wet-bulk density of soft sediments was measured by the analog GRAPE for Cores 1 to 6 , and on three points per section using 2-minute GRAPE for Cores 7 to 48. For pieces of firm sediment (chalk, limestone, and chert), both the 2-minute GRAPE and gravimetric methods were used. Sound-velocity measurements occasionally were made on the Saran-wrapped half cores of firm pieces of chalk, and on almost all mini-core samples normal to both the vertical and horizontal directions. All measured values of sound velocity, wet-bulk density, porosity, and water content are shown in Figure 16.

The sedimentary column penetrated at Site 463 has been divided into four major and four minor acoustic units, which are related to the lithologic units and seismic-reflection data. The values of wet-bulk density and interval velocity (Appendix D) are averaged for each acoustic unit and listed in Table 3.

The limestone samples (below Core 26) show velocity anisotropy, and the mean value of the velocity ratio of horizontal to vertical direction is about 1.045 under wet and 1-bar conditions (described in detail by Fujii, this volume).

\section{PALEOMAGNETISM}

Nearly 100 samples of Cretaceous limestones were taken for paleomagnetic measurements (Sayre, this volume). A large proportion of the samples of the multicolored limestones (Unit II) and tuffaceous and carbonaceous limestones (Unit III) carry a stable component of magnetization, often similar in direction to the natural remanent magnetization. The pelagic and clastic limestones (Unit IV) are more weakly magnetized, and directional data are less reliable. At least two reversedpolarity intervals can be identified in the Chiastozygus litterarius nannoplankton zone of the early Aptian, which may correlate with anomaly $\mathrm{M} 0$ or a reversed interval identified in sediments at DSDP Hole 361 (Keating and Helsley, 1978). The rest of the Aptian and lower Albian seems to be normally magnetized. A paleolatitude estimate for Units II and III is approximately $10^{\circ}$ farther south than that predicted by recent reconstructions, the difference perhaps being due to the effects of compaction, inclination error, the offset dipole, off-vertical drilling, or errors in reconstruction.

\section{CORRELATION OF SEISMIC-REFLECTION PROFILES AND DRILLING RESULTS}

Two strong reflectors are distinct on both the Mahi 7004 (Fig. 5A) and the Glomar Challenger (Fig. 7) airgun reflection profiles. These reflectors can be correlated with a boundary between lithologic units and with lithologic changes that occur within units. Lessdistinct reflectors within acoustic units probably correspond to beds with relatively higher seismic velocities, e.g., limestone and chert layers in the nannofossil-chalk sequence in acoustic unit II.

Correlation of the seismic-reflection profiles with drilling results (Fig. 17) shows four acoustic units, of which three can be related to lithologic units and subunits (Table 2). These four acoustic units include (1) a top unit (corresponding to Lithologic Unit IA) of nannofossil ooze about $0.06 \mathrm{sec}$ (two-way time) thick; (2) a second unit (top of Lithologic Sub-unit IB), with a thickness of about $0.24 \mathrm{sec}$ thick, consisting of chalk and nannofossil ooze; (3) a third unit, corresponding to the bottom part of Lithologic Sub-unit IB with a thickness of about $0.19 \mathrm{sec}$, made up of chalk, limestone, and chert; and (4) a fourth acoustic unit (Lithologic Units II, III, and IV), mostly limestone, partly silicified limestone, and rare chert. The nannofossil ooze of acoustic unit $\mathrm{I}$ is not resolvable on the air-gun seismic-reflection profiles, but a $3.5-\mathrm{kHz}$ profile (Fig. 18) shows an upper transparent layer that corresponds to this unit. No internal reflectors are visible on the $3.5-\mathrm{kHz}$ profile.

The second acoustic unit consists of two major sediment types-ooze and chalk. All transitions occur between foraminifer-nannofossil and nannofossil-foraminifer oozes, through nannofossil and foraminifer chalks. A strong reflector at about $0.3 \mathrm{sec}$ DT sub-bottom corresponds to a lithification change from mostly chalk to a sequence of limestone and chalk with common chert. This reflector marks the boundary between acoustic units II and III. Limestone beds probably are responsible for the strong reflectors.

The bottom acoustic unit (unit IV), which corresponds to Lithologic Units II, III, and IV, has many strong reflectors that most likely correspond to limestone strata. The variations in lithologies used to define the lithologic units cannot be resolved on the seismic-reflection profiles.

Interval velocities, calculated for the acoustic units by averaging measurements of individual samples, correspond fairly well to expected interval velocities calculated from thicknesses of the drilled units. Acoustic unit II has an expected velocity of about $1.76 \mathrm{~km} / \mathrm{s}$, which is near the velocity of $1.73 \mathrm{~km} / \mathrm{s}$ calculated from measurements of individual samples. The third acoustic unit has an expected velocity of about $2.10 \mathrm{~km} / \mathrm{s}$, which also corresponds well to the average measured velocity of 2.14 $\mathrm{km} / \mathrm{s}$ obtained from the individual samples. Acoustic unit IV has a large range of measured velocities, from $2.76 \mathrm{~km} / \mathrm{s}$ in the Aptian ashy and carbonaceous limestone beds to $3.63 \mathrm{~km} / \mathrm{s}$ in the partly silicified limestone strata of the Barremian sequence. Basement is not apparent on either of the air-gun seismic-reflection profiles, and it is impossible to calculate its sub-bottom depth from the available data.

\section{BIOSTRATIGRAPHY}

\section{Biostratigraphic Summary}

The 822.5-m-thick sedimentary section continuously cored at Site 463 represents a sequence from Quaternary to Barremian. Included are two substantial hiatuses of 16 to $17 \mathrm{~m} . y$. ., spanning intervals from the Maastrichtian through part of the Eocene, and the uppermost Oligocene through the middle Miocene, respectively. Another shorter hiatus of about 7 m.y. spans the Santonian and lower Campanian, and a very condensed series 

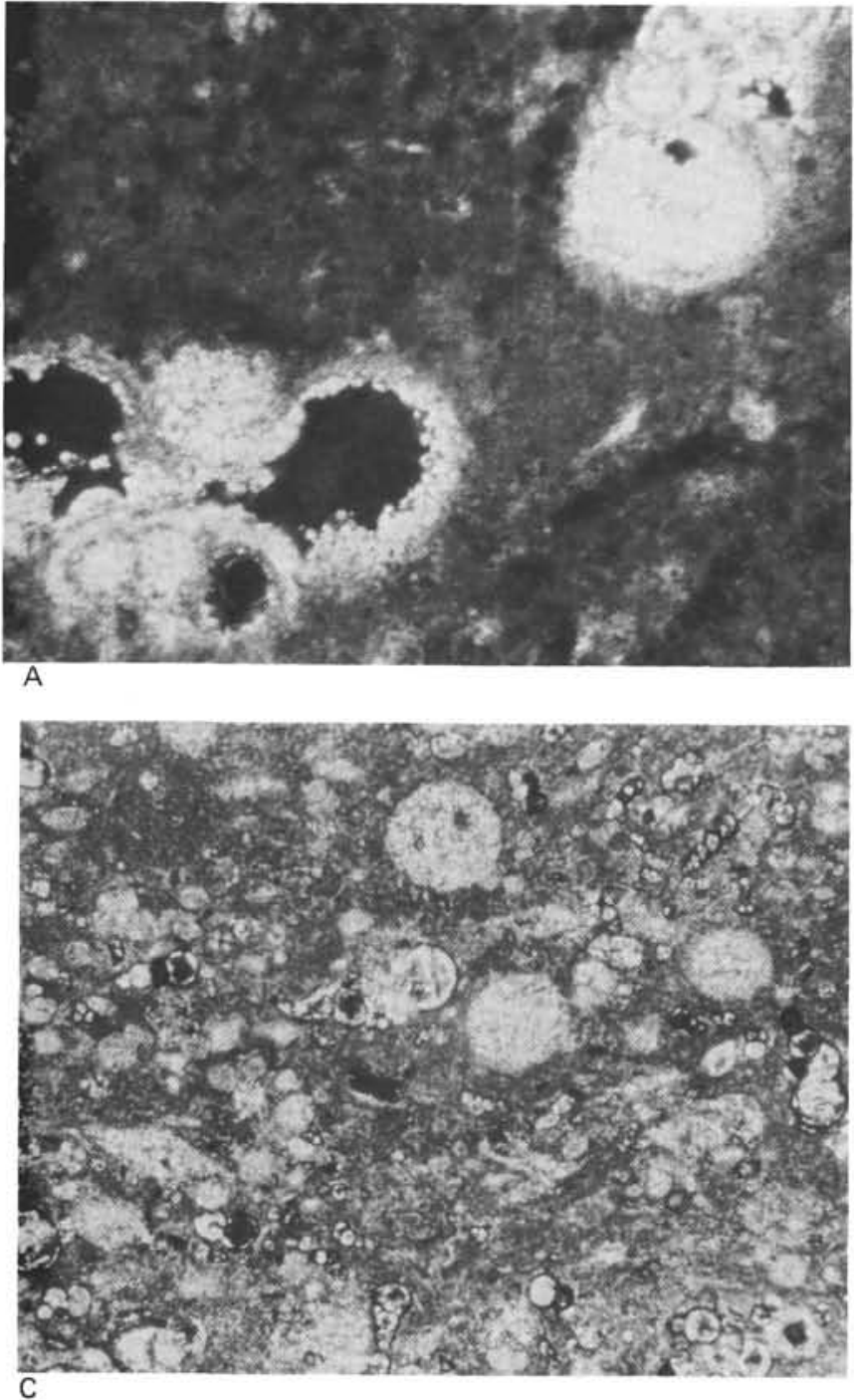
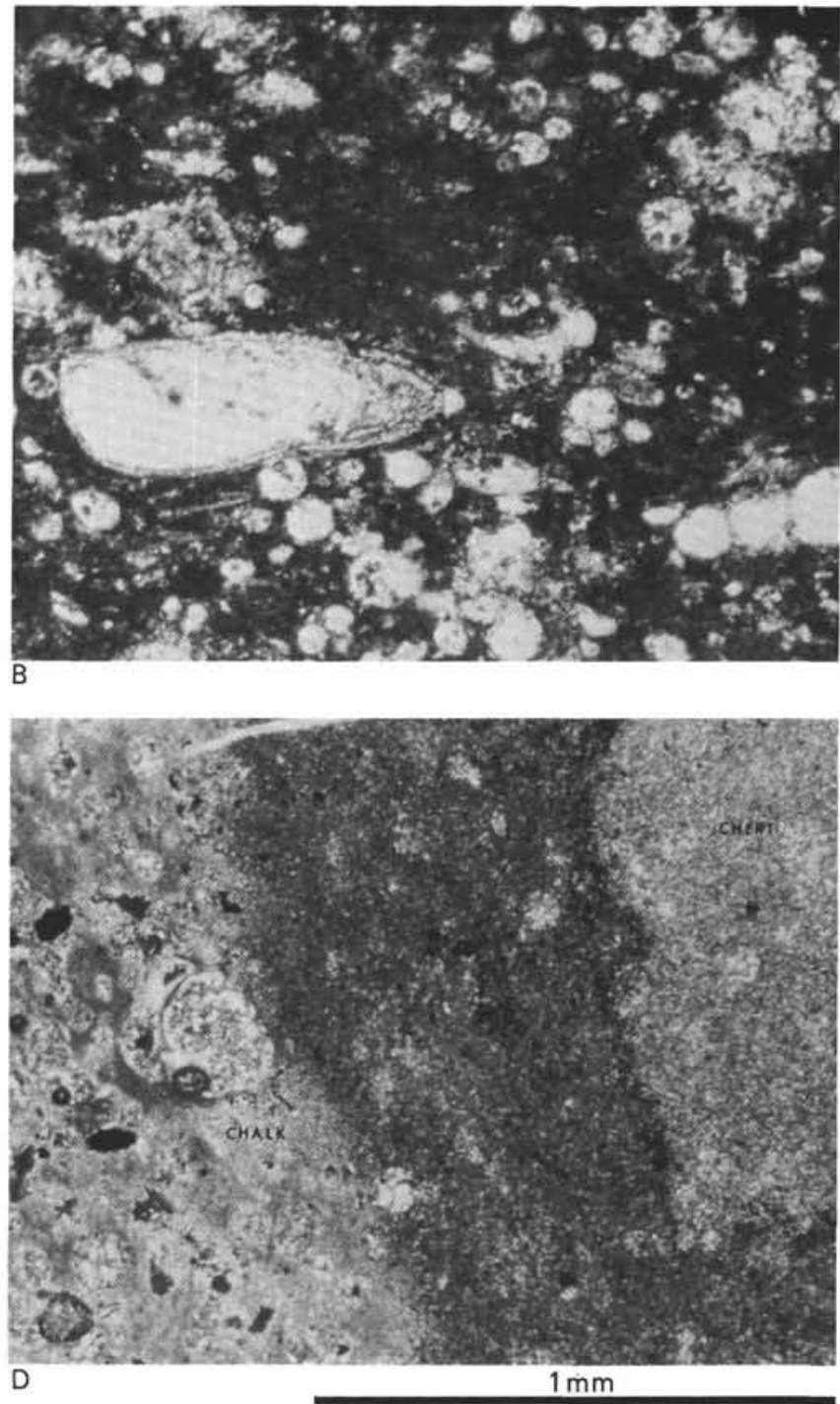

Figure 14. $\mathrm{SiO}_{2}$-replacement sequence (not in stratigraphic sequence; bar $\left.=1 \mathrm{~mm}\right)$. A. 57-2, 54-56 cm (502 m; Unit II). Chambers of foraminifers partly to completely filled with $\mathrm{SiO}_{2}$. Tests of foraminifers and matrix are still $\mathrm{CaCO}_{3}$ (cross-polarized light). B. 50-1, 58-60 cm (434 m; Unit IB). Radiolarians and foraminifers filled with $\mathrm{SiO}_{2}$, and some of the $\mathrm{CaCO}_{3}$ matrix replaced by $\mathrm{SiO}_{2}$. Foraminifer tests still CaCO 3 (crosspolarized light). C. 36-1, 0-2 cm (310 m; Unit IB). Radiolarians and foraminifers filled with $\mathrm{SiO}_{2}$. Matrix mostly microcrystalline $\mathrm{SiO}_{2}$ with some $\mathrm{CaCO}_{3}$. Foraminifer tests still $\mathrm{CaCO}_{3}$ (plane polarized light). D. 38-1, 10-11 cm (329 m; Unit IB). Replacement of chalk (left) by chert (right), with a transition zone between (darker gray in center). Radiolarian and foraminifer tests filled with $\mathrm{SiO}_{2}$ throughout (cross-polarized light). E. 69-2, 148-150 cm (607 m; Unit III). Radiolarian(?) filled with sparry calcite, and with a scalloped overgrowth of $\mathrm{SiO}_{2}$. Matrix is microcrystalline calcite (cross-polarized light). F. 69-2, 148-150 cm (607 m; Unit III). Contact between microcrystalline CaCO $\mathrm{Catrix}_{3}$ (left) and microcrystalline $\mathrm{SiO}_{2}$ matrix (right) (cross-polarized light). G. 61-3, 109-111 cm (539.5 m; Unit II). Contact between altered volcanic ash (right) and micritic calcite matrix with foraminifers (left) (cross-polarized light). H. 79-1, 7-9 cm (699.8 m; Unit IV). Parallel orientation and imbrication of carbonate clasts at contact between bed of clastic limestone and bed of siliceous limestone and chert (cross-polarized light).

(with possible hiatuses) encompasses the middle Eocene through most of the Oligocene. The Cenozoic sequence $(47 \mathrm{~m})$ is very condensed, whereas Cretaceous deposits $(775.5 \mathrm{~m})$ constitute the largest part of the sedimentary sequence.

A summary of the various fossil-group zonations plotted against sub-bottom depths is presented in the graphic hole summary (Fig. 19).

The sedimentation-rate curve is shown in Figure 20. There is good agreement between calcareous nannofossils and planktonic foraminifers in age assignments of recovered sediments throughout the upper 560 meters. Below that level, foraminifers are absent, and sedi- ments were dated by nannofossils. Radiolarian zonation was possible only for Lower Cretaceous strata; it appears to be in general agreement with the calcareousplankton zonation. However, because its calibration to the absolute time scale and to other fossil-group zonations is poorly documented, the age assignment for the radiolarian zones represented on Figure 20 remains tentative. No diatoms were observed.

The section consists, from top to bottom, of:

1) 34 meters of upper Neogene (upper Miocene to Quaternary) nannofossil ooze (Cores 1-4) which contains abundant calcareous plankton. Nannofossils are mostly well preserved, whereas planktonic foraminifers 


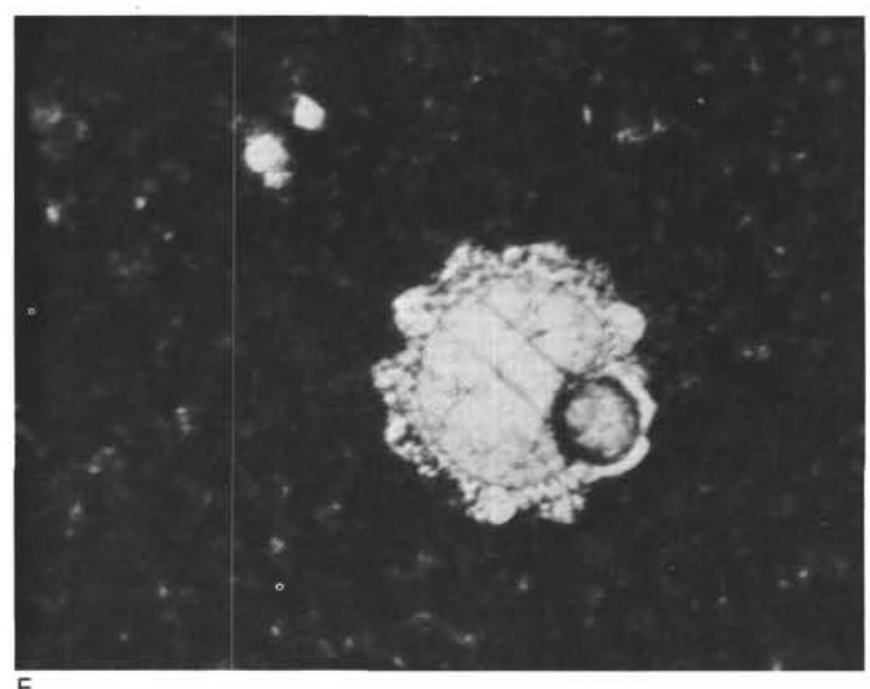

E

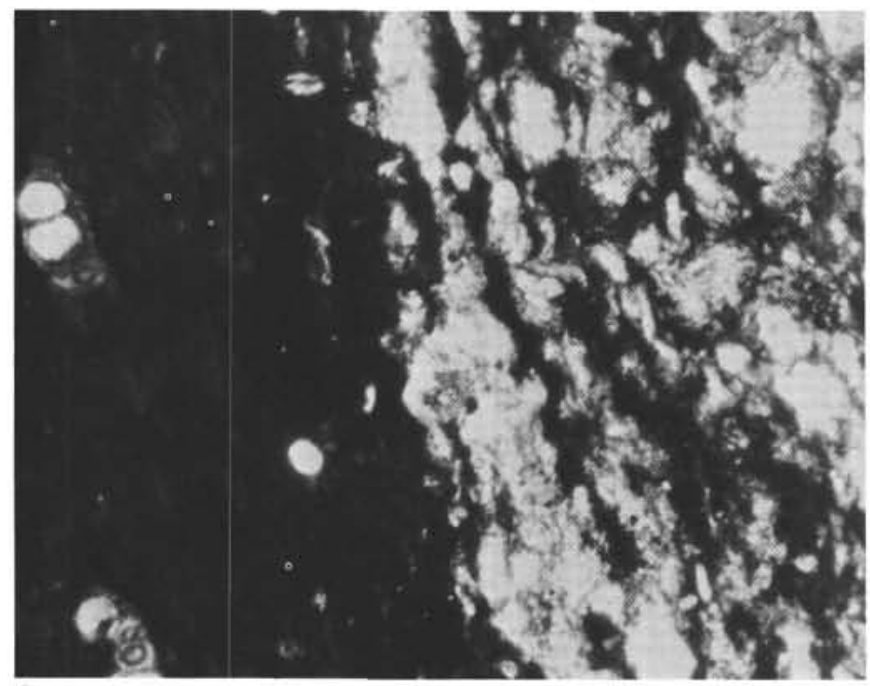

G

Figure 14. (Continued).

are moderately well preserved. Of special interest is the extraordinary abundance of discoasters in upper Miocene and Pliocene assemblages. Although condensed, the sequence appears continuous. Core 4 contains a mixture of reworked sediments of early and middle Miocene, Oligocene, Eocene, and Late Cretaceous ages.

2) A hiatus at about 34 meters (between Cores 4 and 5), spanning the entire middle and lower Miocene and uppermost Oligocene, equivalent to a time span of about $16 \mathrm{~m} . \mathrm{y}$.

3) 12.8 meters of Paleogene nannofossil ooze (Cores 5 and 6 and upper $3.3 \mathrm{~m}$ of Core 7) which contains abundant, moderately well preserved calcareous plankton. This section is extremely condensed, with a possible hiatus between the middle Eocene and the Oligocene. Reworking of Eocene floras was noted in some Oligocene samples.

4) A hiatus at 46.8 meters (Core 7 , Section $3,30 \mathrm{~cm}$ ) which encompasses most of the lower Eocene, the entire Paleocene, and part of the Maastrichtian. It represents a time span of approximately $17 \mathrm{~m} . \mathrm{y}$.
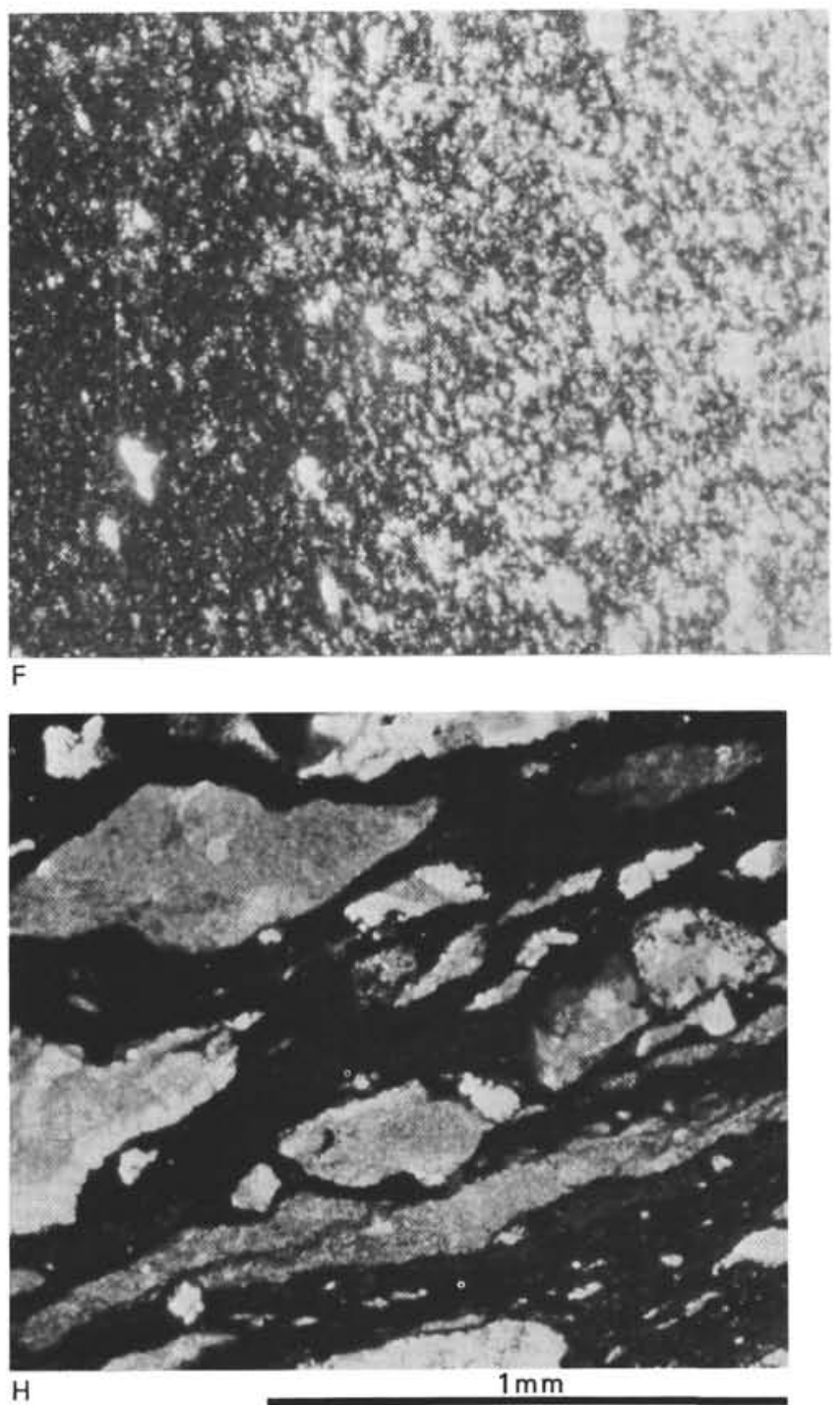

$\mathrm{H}$

5) $>350$ meters of Upper to middle Cretaceous chalk and limestone (lower part of Ccore 7 through Core 47) which contain common to abundant, poorly preserved calcareous nannoplankton and abundant planktonic foraminifers. The latter are mostly well preserved in the Maastrichtian to upper Campanian (Cores 7-27) and moderately well preserved in the Coniacian to upper Albian (Cores 28-51). Compared to other Pacific Cretaceous sections, the preservation of foraminifers throughout the upper and middle Cretaceous section at Site 463 is remarkably good and consistent. The section appears continuous, except for a possible hiatus (or very condensed section) which encompasses the lower Campanian and Santonian, (a time span of about 6 m.y.). Displaced shallower-water benthic foraminifers were found in most of the Maastrichtian sediments, and in a few Cenomanian horizons.

6) 400 meters of Lower Cretaceous pelagic limestone (Cores 48-92), interbedded with clastic limestone in the lower 190 meters. Calcareous nannofossils are common and poorly preserved. Foraminifers are rare and poorly 


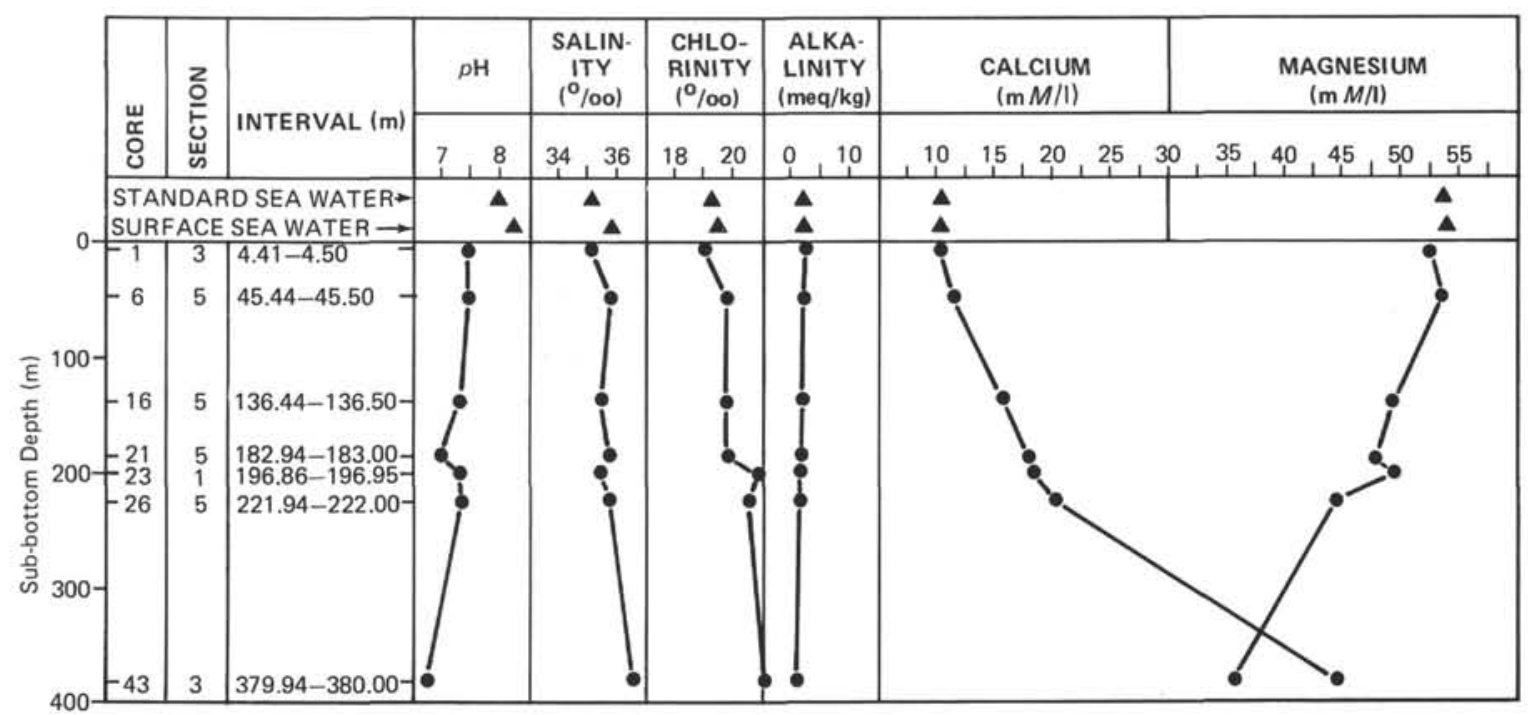

Figure 15. Interstitial-water geochemistry, Site 463.

preserved down to Core 63 (preservation becoming poorer downward in the section as recrystallization increases), and are virtually absent below that level.

Radiolarians, which were absent in the overlying sediments, are common in this part of the sequence; above 660 meters (Core 74), they are confined to sandy layers and are recrystallized, whereas below that level they occur throughout the section and are well preserved. However, from nannofossil, paleomagnetic, and sedimentation-rate data, the lowermost sediments appear to be Barremian, approximately $118 \mathrm{~m} . \mathrm{y}$. old, near the late/early Barremian boundary.

\section{Nannoplankton}

Calcareous nannofossils are present in all 92 cores from Site 463.

An abbreviated Cenozoic section with several hiatuses is recorded in the first seven cores of nannofossil ooze; thereafter, a relatively complete section of early Maastrichtian to Barremian age was recovered from chalks and limestones to the sub-bottom depth of 822.5 meters.

\section{Cenozoic}

Species assemblages of late Miocene to Recent, Oligocene, and early to middle Eocene age are recognized in the first seven cores. A large hiatus between the early Eocene and early Maastrichtian is recorded in Section $7-3$, in which a foraminifer nannofossil chalk is first encountered.

An apparently complete upper Miocene to Recent sequence of nannofossil zones (NN11-NN21) is recognized in the first four cores. The nannofloras are abundant and mostly well preserved (slight to moderate etching). The upper Miocene and Pliocene assemblages are marked by an extraordinary abundance of discoasters and occasionally ceratolithids. In most samples, this dominance is accentuated by dissolution of most of the smaller coccoliths.
The top of Core 1 tentatively has been assigned to the Gephyrocapsa oceanica (NN20)/Emiliania huxleyi (NN21) zonal interval. Sample 463-1-1, $97 \mathrm{~cm}$ can be assigned to the Gephyrocapsa oceanica (NN20) Zone. Samples from Sections 1-2 and 1-3 are assigned to the Pseudoemiliania lacunosa (NN19) Zone. Samples from Sections $1-4$ to $4, C C$ contain a succession of species, mostly discoasters and ceratolithids, readily assignable to the standard zones of late Miocene to Pliocene age. Samples from Core 4 contain, in addition to the restricted index species Discoaster quinqueramus (NN11), an irregular mixture of reworked index species of early and middle Miocene, Oligocene, and early to middle Miocene age. Allochthonous species of Oligocene and early to middle Eocene age are the same as those found below in stratigraphic superposition (Core 5 to Section 7-3).

The next distinct biostratigraphic unit (Core 5 to Section 6-6) is recognized by the presence of Sphenolithus predistentus, $S$. distentus, and $S$. speudoradians. The co-occurrence of these species permits assignment to the Sphenolithus predistentus (NP23)/Sphenolithus distentus (NP24) zonal interval. Samples from this interval do not contain helicosphaerids, pontosphaerids, or rhabdosphaerids. Nannofossil assemblages are abundant, but generally slightly to moderately overgrown. Certain samples contain reworked species of early to middle Eocene age.

Sample 6,CC contains a diagnostic and moderately well-preserved assemblage of middle Eocene age which probably correlates with the lower part of the Discoaster tani nodifer (NP16) Zone. Samples from Sections 7-1 to 7-3 contain moderately well-preserved nannofloras of the Discoaster lodoensis (NP13) Zone, of late early Eocene age.

\section{Mesozoic}

Abundant to rare, but poorly preserved nannofossil assemblages are found throughout the Cretaceous sec- 
tion. The Cretaceous sediments in Samples 463-7-3, 30 $\mathrm{cm}$ through $92, \mathrm{CC}$ can be divided into 12 intervals.

1) Lower Maastrichtian $(7-3,30 \mathrm{~cm}$ to $16, \mathrm{CC}): \mathrm{Ar}$ kangelskiella cymbiformis Zone.

2) Upper Campanian to lower Maastrichtian (17-1, $29-30 \mathrm{~cm}$ to 22,CC): Tetralithus trifidus Zone.

3) Upper Campanian (23-1, 51-52 cm to $25-2,62-63$ $\mathrm{cm})$ : Tetralithus gothicus Zone.

4) Coniacian to upper Campanian (25,CC to 30,CC). The common to abundant assemblages in this interval are characterized by the lack of certain index species. The upper limit of this zonal interval is determined. by the first occurrence of Tetralithus gothicus, and the lower limit by the last occurrence of Corollithion achylosum.

5) Turonian $(31, \mathrm{CC}$ to $37, \mathrm{CC})$. The top of this zonal interval is determined by the last occurrence of Corollithion achylosum, and the lower limit by the, last occurrence of Lithraphidites alatus.

6) Uppermost Albian to lowermost Turonian (38-1, $29-30 \mathrm{~cm}$ to $50-1,52-53 \mathrm{~cm})$ : Lithraphidites alatus Zone.

7) Upper Albian (50,CC to 52,CC): Eiffellithus turriseiffeli Zone.

8) Middle Albian (53-1, 122-124 cm to 55-1, 22-23 $\mathrm{cm})$ : Prediscosphaera cretacea Zone.

9) Lower Albian (55-1 [base] to 59,CC): Parhabdolithus angustus Zone (upper part). The upper limit of this zonal interval is determined by the first occurrence of Prediscosphaera cretacea, and the lower limit by the last occurrence of Nannoconus bucheri.

10) Upper Aptian $(60, \mathrm{CC}$ to $65-1,7-8 \mathrm{~cm}):$ Parhabdolithus angustus Zone (lower part). This zonal interval can be characterized by the co-occurrence of Lithastrinus floralis and Nannoconus bucheri.

11) Lower Aptian (65,CC to $78-1,87-88 \mathrm{~cm})$ : Chiastozygus litterarius Zone.

12) Barremian (79-1, 36-37 cm to 92,CC): Micrantholithus obtusus Zone. The absence of resistant Calcicalathina oblongata strongly suggests that drilling at Site 463 terminated in sediments of Barremian age.

\section{Foraminifers}

A visual estimate of the relative abundance of the main components of the sediment coarse fraction is presented in Appendix B. Foraminifers are the dominant constituent of the Neogene, Paleogene, and Cretaceous ooze and chalk recovered in Cores 1 through 50. They are moderately well to poorly preserved in the Neogene (Cores 1-4), moderately well preserved in the Oligocene (Core 5), well preserved in the Eocene through Coniacian (Cores 6-27), and moderately well-preserved in the remaining Cretaceous chalks (Cores 30-50); in the latter, recrystallization is noticeable, and chalk aggregates constitute a significant amount of the coarse fraction.

In the Lower Cretaceous limestone, below Core 50, radiolarians and limestone chips constitute the main components of the coarse fraction. Foraminifers are rare and poorly preserved in Cores 52 to 67 (Albian and Aptian), becoming rarer and more poorly preserved as recrystallization becomes more and more pronounced down-section; foraminifers disappear below Core 67.

\section{Neogene}

The highest sample from Core $1(1-1,7-9 \mathrm{~cm})$ is Quaternary in age (Zone N22), as indicated by the presence of Globorotalia truncatulinoides. Section 1,CC is attributed to the upper Pliocene (N21), based on the presence of Globigerinoides fistulosus at a biostratigraphic level above the last occurrence of Sphaeroidinellopsis spp. (known to have become extinct $2.8 \mathrm{~m}$.y. ago), as the latter species were not found. Although rare occurrences of temperate species (Globorotalia crassaformis, $G$. inflata) were observed, the faunal assemblage appears to represent significantly warmer water than that at the top of the core. Two tropical species, $S$. dehiscens and $G$. cultrata, constitute most of the fauna.

Section 2,CC is lower Pliocene (N19-N20), based on the co-occurrence of Sphaeroilinellopsis spp. and $G$. tumida. The fauna is largely dominated by two resistant, warm-water species, Sphaeroidinellopsis seminulina and S. subdehiscens, probably as a result of dissolution of a warm-water assemblage.

Because of poor preservation and probable dissolution of most of the taxa, the age of Section 3,CC cannot be determined precisely. It belongs to the zonal interval from N14 to N19 or N20 (middle Miocene to lower Pliocene), as shown by the occurrence of "Globigerina" nepenthes. This species dominates the fauna and is accompanied by common $S$. seminulina and S. subdehiscens. Section 4,CC contains the same middle Miocene to lower Pliocene planktonic assemblage as above, but mixed with a large amount of Eocene and Oligocene faunas and a few Upper Cretaceous species.

Benthic foraminifers are characteristic of a bathyal environment. They include Favocassidulina favus, Planulina wuellerstorfi, Melonis pompilioides, Oridorsalis umbonatus, Eggerella bradyi, Uvigerina sp., and Stilostomella sp.

\section{Paleogene and Cretaceous}

Paleogene foraminifers occur in Cores 4 to 7 , and Cretaceous foraminifers in Cores 7 to 67 . Whereas $\mathrm{Pa}$ leogene faunas are strongly mixed, a probably continuous and generally well-preserved Cretaceous sequence was recovered.

The Paleogene contains admixtures of Oligocene, Eocene, and Paleocene forms. Index fossils include $C$. cubensis, and $G$. ampliapertura in the Oligocene and $G$. barri, $M$. aragonensis, $T$. cerroazulensis, $M$. aegra, and $M$. velascoensis in the Paleocene.

Maastrichtian. the G. contusa (Cores 7-12) and the $G$. scutilla (Cores 15-20) zones were recognized. The foraminifers are well preserved, and are faunas diverse. The late Maastrichtian index species Raceniguembelina fructicosa is not present at this site.

Campanian. the zonal interval from the G. calcarata Zone to the G. subspinosa Zone (Cores $21-25$ ) and the G. elevata Zone (Cores 24 and 25 ) were recognized. Fossils are well preserved, although there are large con- 


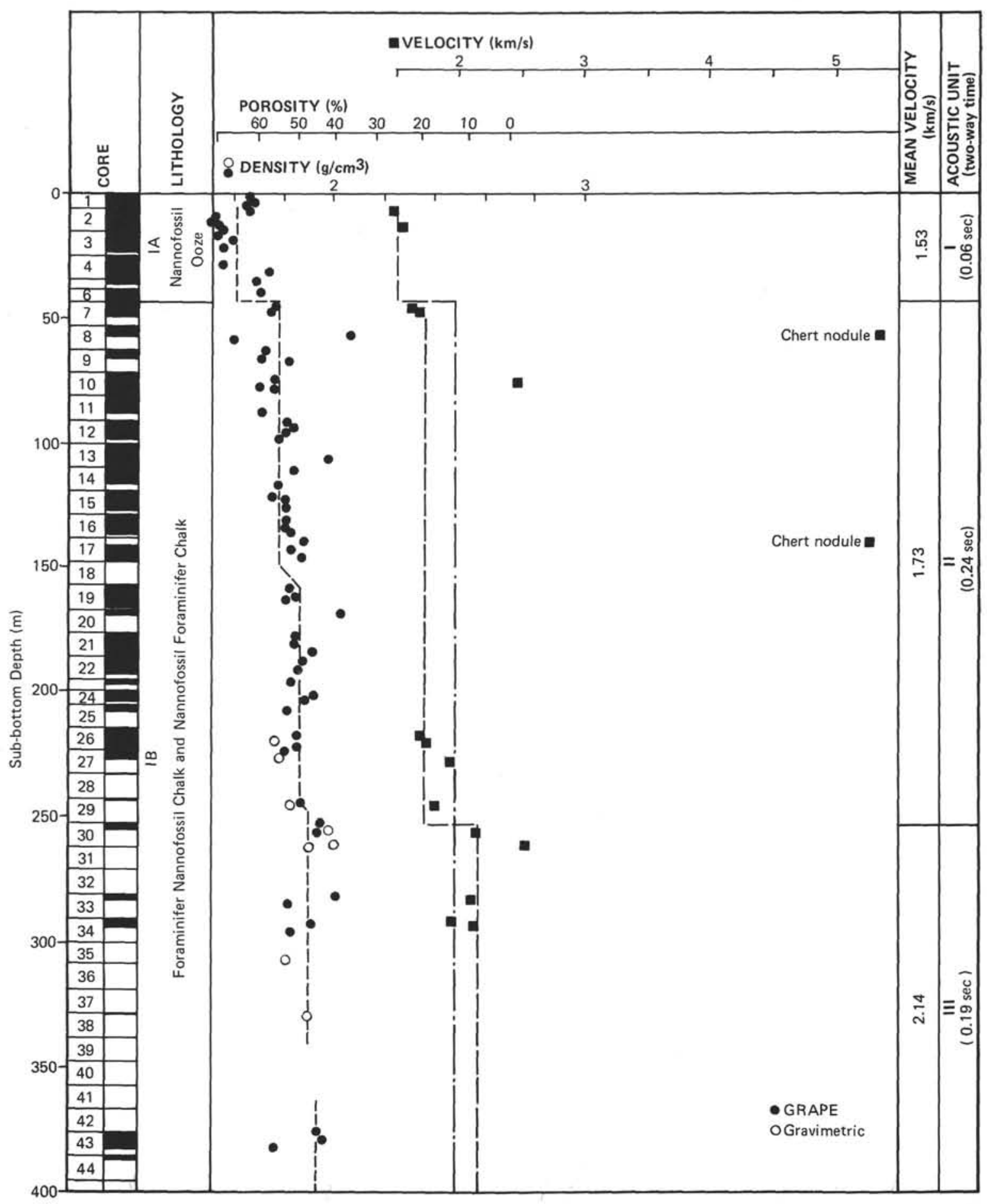

Figure 16. Wet-bulk density and compressional-wave velocity along the vertical direction plotted as a function of hole depth (see Appendix D for individual measurements). Lithologic unit, mean wave velocity, and two-way travel times are also indicated. Broken lines indicate mean values of wet-bulk density and velocity for each subdivided layer; dash-dot lines indicate values averaged over each lithologic unit.

centrations of test fragments. G. subspinosa is present in the G. elevata Zone, placing it in the Campanian, not the Santonian.

Turonian to Coniacian. the G. rensi-G. sigali (Cores 6-29), G. helvetica (Cores 33-34), and H. lehmanni $(34, C C-38)$ Zones were identified. Whiteinella and Rotalipora are present, along with several species of heterohelicids and globigerinids. The planktonic foraminifers are only moderately well preserved, and occasionally badly recrystallized $(30, \mathrm{CC})$. Benthic foraminifers are rare.

Cenomanian. The $R$. cushmani Zone (Cores 39-43) and the $R$. gandolfi-R. greenhornensis zonal interval (Cores 44-47) were recognized. Rotaliporids are numer- 


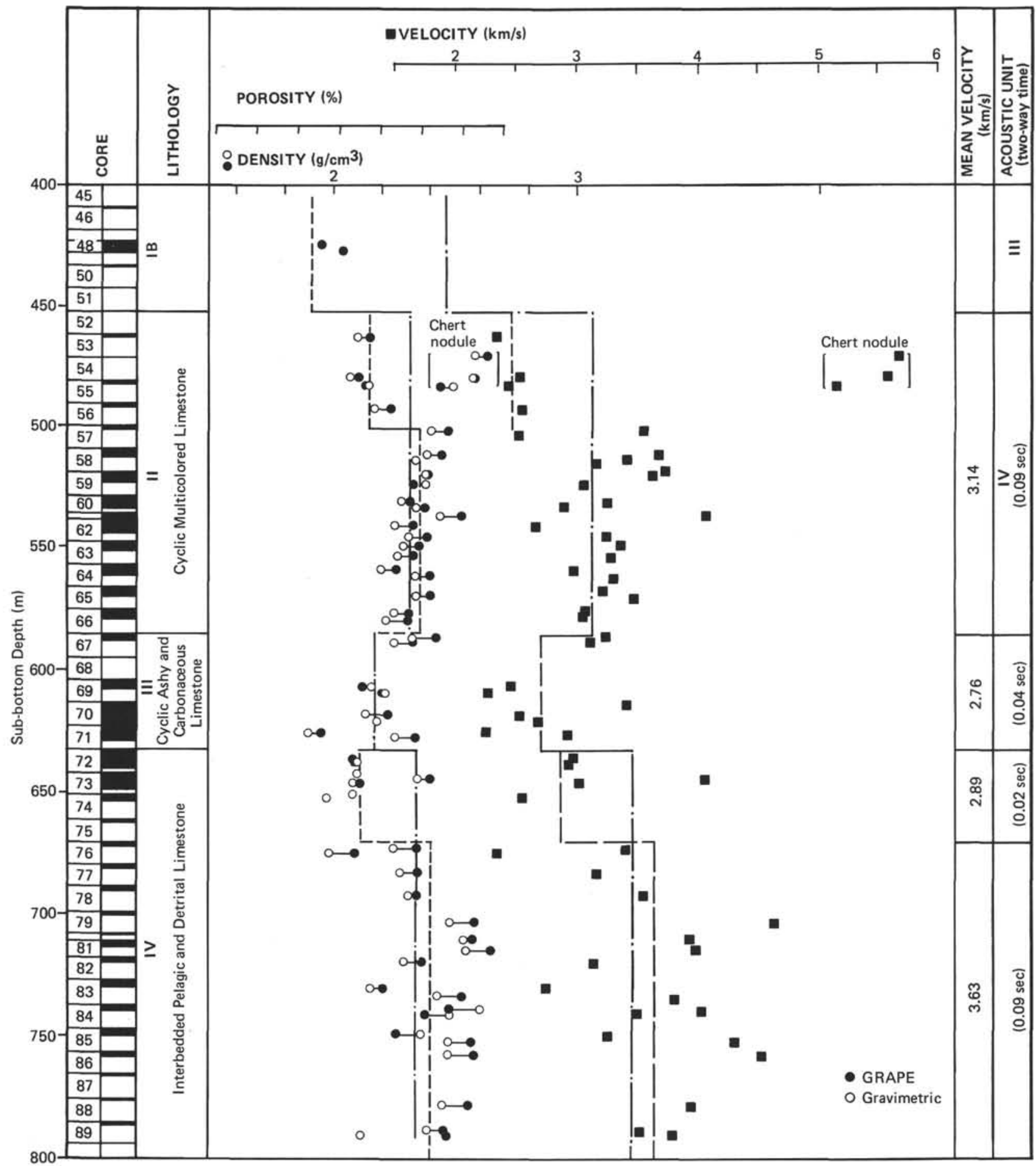

Figure 16. (Continued).

ous, diverse, and generally well preserved; they include $R$. reicheli, $R$. turonica, $R$. brotzeni, $R$. appeninica, and $R$. montsalvensis.

Albian. Planktonic foraminifers are occasionally moderately well preserved, but poor preservation is more typical through this interval. Species of Praeglobotruncana, Ticinella, and Rotalipora and numerous hedbergellids are present. No shackoinids were found at this site.

Aptian. The foraminifers are small and very poorly preserved. Only Globigerinelloides algerianus and a few small hedbergellids are present, along with some benthic foraminifers.

\section{Radiolarians}

\section{Abundance and Preservation}

Three intervals can be defined in the sedimentary sequence at Site 463 on the basis of radiolarian occurrences:

1) Cores 1 through 55, in which radiolarians are mainly absent. Only a few un-identifiable fragments were found in Cores 1, 2, 30, 52, and 53 . 
Table 3. Physical properties of acoustic units at Site 463 .

\begin{tabular}{lccccc}
\hline $\begin{array}{c}\text { Acoustic } \\
\text { Unit }\end{array}$ & $\begin{array}{c}\text { Sub-bottom } \\
\text { Depth } \\
(\mathrm{m})\end{array}$ & $\begin{array}{c}\text { Density } \\
\left(\mathrm{g} / \mathrm{cm}^{3}\right)\end{array}$ & $\begin{array}{c}\text { Velocity } \\
(\mathrm{km} / \mathrm{s})\end{array}$ & $\begin{array}{c}\text { DT } \\
(\mathrm{sec})\end{array}$ & $\begin{array}{c}\text { Lithologic } \\
\text { Unit }\end{array}$ \\
\hline I & $0-47$ & 1.61 & 1.53 & 0.06 & IA \\
& $(45-450)^{*}$ & $(1.83)^{*}$ & $(1.95)$ & $(0.41)$ & (IB) \\
II & $7-250$ & 1.82 & 1.73 & 0.24 & IB \\
III & $250-450$ & 1.91 & 2.14 & 0.19 & IB \\
IVA & $450-588$ & 2.15 & 3.14 & 0.09 & II \\
B & $588-633$ & 2.18 & 2.76 & 0.04 & III \\
C & $633-670$ & 2.13 & 2.89 & 0.02 & IV \\
D & $670-823$ & 2.41 & 3.63 & 0.09 & IV \\
\hline
\end{tabular}

Note: A value in parenthesis is simple average for lithologic Unit IB.

2) Cores 56 through 74 , in which radiolarians are confined to sandy layers. The tests are usually recrystallized, and many internal molds of iron oxide or pyrite (with or without the original skeleton) were observed. The interval molds are composed of iron oxide down to Core 63 , and or pyrite below that level.

3) Cores 75 to 92 , in which mostly well-preserved radiolarians occur consistently throughout the section.
Internal molds of pyrite were also observed in this interval.

In the lowermost few cores, a few samples contain well-preserved tests together with recrystallized tests and internal molds. The co-occurrence of these three types of radiolarians probably results from turbidite displacement. Displacement in these samples is also suggested by (1) low-diversity assemblages, (2) sorting of the abundant, well-preserved, spherical tests, and (3) fragmentation of all Nasselaria tests.

\section{Radiolarian Biostratigraphy}

The zonation of Foreman (1975), established at DSDP Leg 32 sites, was followed. Three zones were identified in the Lower Cretaceous: the Acaeniotyle umbilicata Zone in Cores 56 through 70, the Eucyrtis tenuis Zone in Cores 70 through 89, and the Sethocapsa trachyostraca Zone in Cores 89 through 92 . The calibration of these radiolarian zones to the absolute time scale and to calcareous-fossil zonations, however, is poorly documented. At this stage of knowledge, chronostratigraphy of the Lower Cretaceous is difficult to establish solely on the basis of radiolarians.
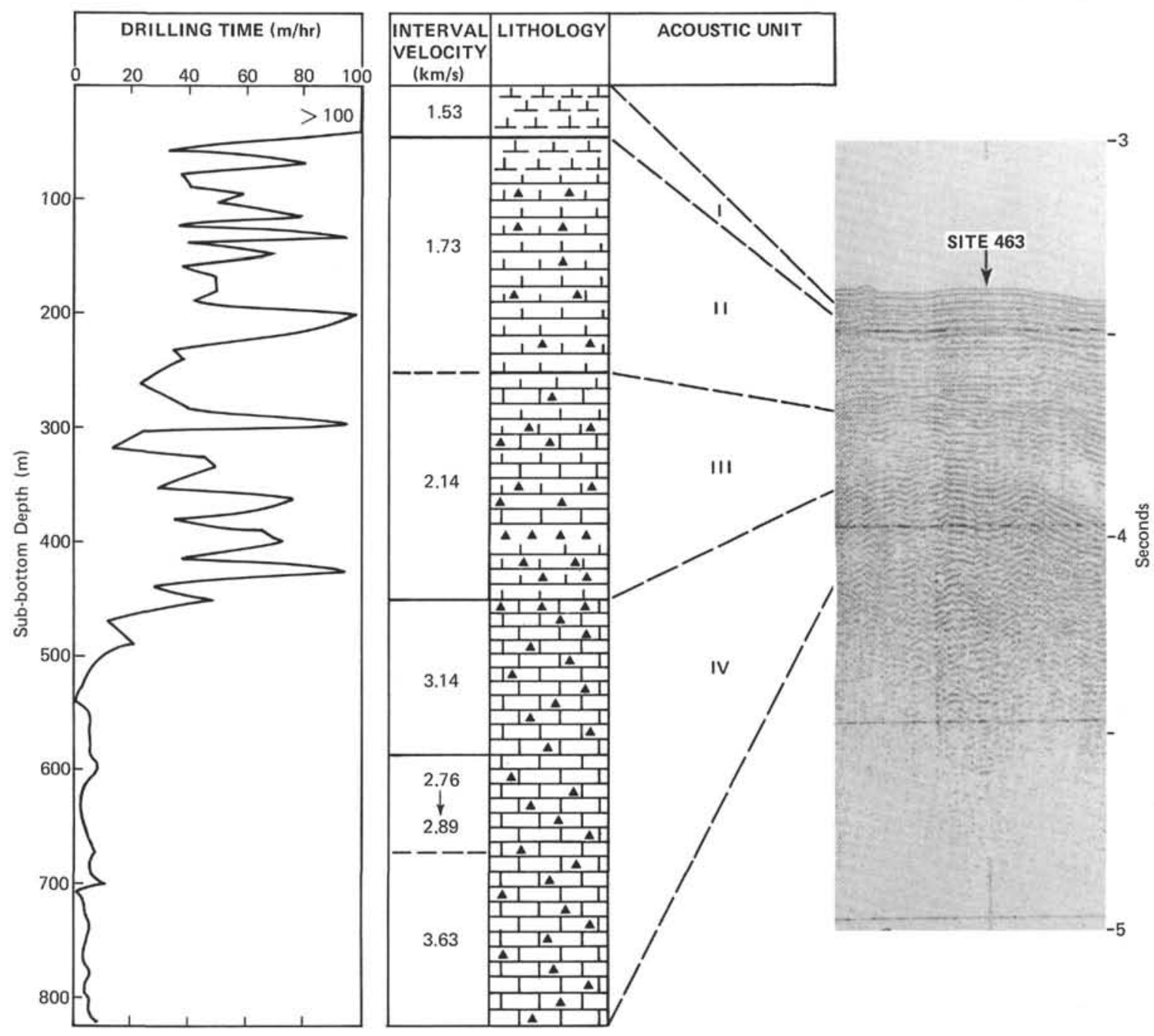

Figure 17. Correlation of drilling time, lithology, acoustic units and seismic-reflection profile at Site 463. 


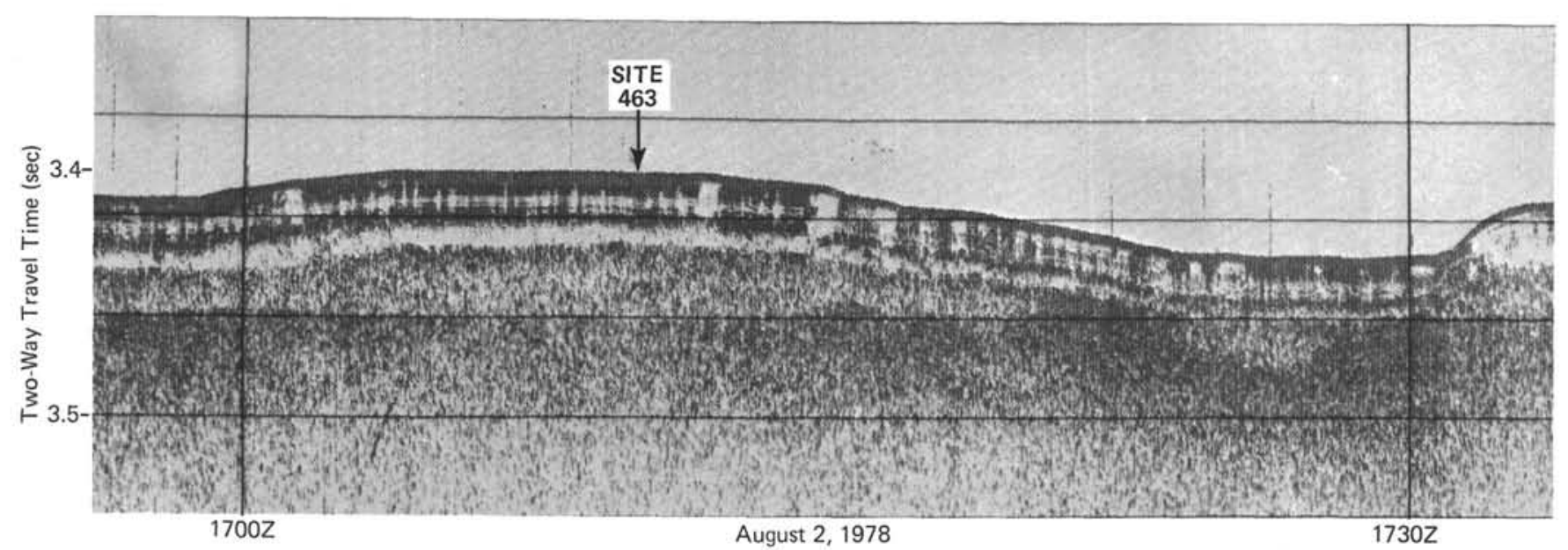

Figure 18. Seismic-reflection profile $(3.5 \mathrm{kHz})$ along Glomar Challenger track line, made during approach to Site 463.

From the data of calcareous plankton, paleomagnetics, and sedimentation rates at Site 463 , it appears that the $A$. umbilicata/E. tenuis zonal boundary occurs in the Aptian, and the E. tenuis/S. trachyostraca boundary in the Barremian.

\section{SEDIMENTATION RATES}

Average sedimentation rates at Site 463 have been estimated (Table 4) using the time scales given in the Introduction to this volume. Corrections for differential compaction have not been applied. Data from each fossil group are reported on Figure 20, a mean sedimentation-rate curve.

The oldest reliable paleontological datum recognized at Site 463 is the last occurrence of the nannofossil Nannoconus colomii, which marks the Aptian/Barremian boundary. Sediments deposited during the early late Aptian in the interval between the level of this datum $(718 \mathrm{~m}$ ) and 556.5 meters (where the G. algerianus planktonic-foraminifer zone was identified, in good agreement with the $P$. angustus/C. literrarius nannofossil-zone boundary) accumulated at an average rate of 36 $\mathrm{m} / \mathrm{m}$.y. Assuming a constant sedimentation rate for the lowermost 104.5 meters of the section, the hole terminated in Barremian sediments approximately 118 m.y. old (at the upper/lower Barremian boundary). This is in good agreement with the nannofossil data, as the species Calcicalathina oblongata, which last occurs in the uppermost lower Barremian, was not found.

The relatively high sedimentation rate of 36 to 37 $\mathrm{m} / \mathrm{m}$.y. for the lower 265 meters of Hole 463 probably resulted from the influx of debris from shallow-water carbonates. The sedimentation rate of the overlying pelagic limestone decreases to an average value of 11 $\mathrm{m} / \mathrm{m}$.y. during the late Aptian through the early Santonian. From an examination of the sedimentation-rate curve for that interval of time, it appears that sedimentation decreased slightly in the late Albian, whereas it increased in the early and middle Cenomanian during the time of maximum chert deposition (poorest recovery in Cores 40 through 50 ).

The highest occurrence of the nannofossil Nannoconus bucheri, whose level of extinction marks the
Aptian/Albian boundary, is deeper than the level of this boundary as indicated by the sedimentation-rate curve (Fig. 20), and it is probable that the upper range of this species is curtailed here.

Sedimentation during the late Santonian and most of the Campanian appears to have been very reduced, having a low value of $2 \mathrm{~m} / \mathrm{m}$.y. This was followed by an abrupt and marked increase during the late Campanian and early Maastrichtian. Sediments were deposited during that time at an average rate of $42 \mathrm{~m} / \mathrm{m}$.y. This high value may result from the equatorial crossing of the site at this time, according to the Lancelot and Larson (1975) tectonic model for Pacific Plate motion (Fig. 21). It is also noticeable that an influx of displaced shallowwater benthic foraminifers occurred in the sediments deposited during that interval of high accumulation rate.

A major hiatus of 17 m.y. spans the Cretaceous/Tertiary boundary. Sedimentation resumed very slowly in the late early Eocene. During the remainder of the Paleogene, sediments accumulated at the very reduced average rate of $0.5 \mathrm{~m} / \mathrm{m}$.y. Although a number of fossil zones were recognized in their normal sequential order, some hiatuses may have occurred during that interval of time.

After a major hiatus of 16 m.y., spanning the late Oligocene and the entire early and middle Miocene, sedimentation resumed again in the late Miocene. It was accompanied by reworking of sediments deposited during the preceding time of slow deposition or nondeposition at the site (Late Cretaceous, Eocene, Oligocene, early and middle Miocene). From that time, sedimentation appears to have been undisturbed and continuous through the late Miocene to Pleistocene, although very slow (average rate $3.5 \mathrm{~m} / \mathrm{m} . \mathrm{y}$.).

\section{SUMMARY AND CONCLUSIONS}

\section{Regional Framework}

The Mid-Pacific Mountains, presently located in the central subtropical North Pacific (Fig. 1) are an ancient structural high rising 2000 to 3000 meters above the surrounding abyssal plain, whose crust is believed to be 


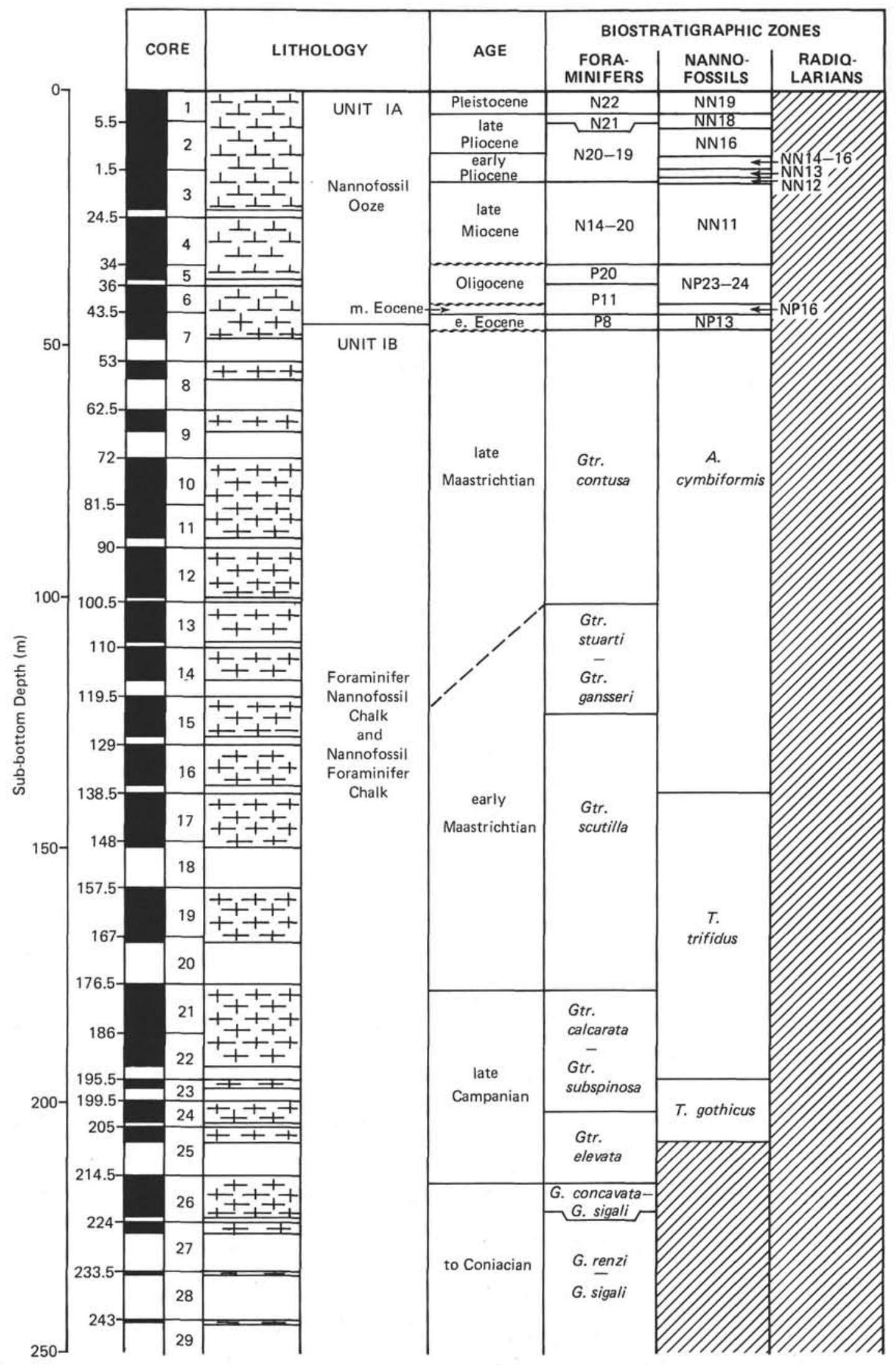

Figure 19. Biostratigraphy of Site 463 . 


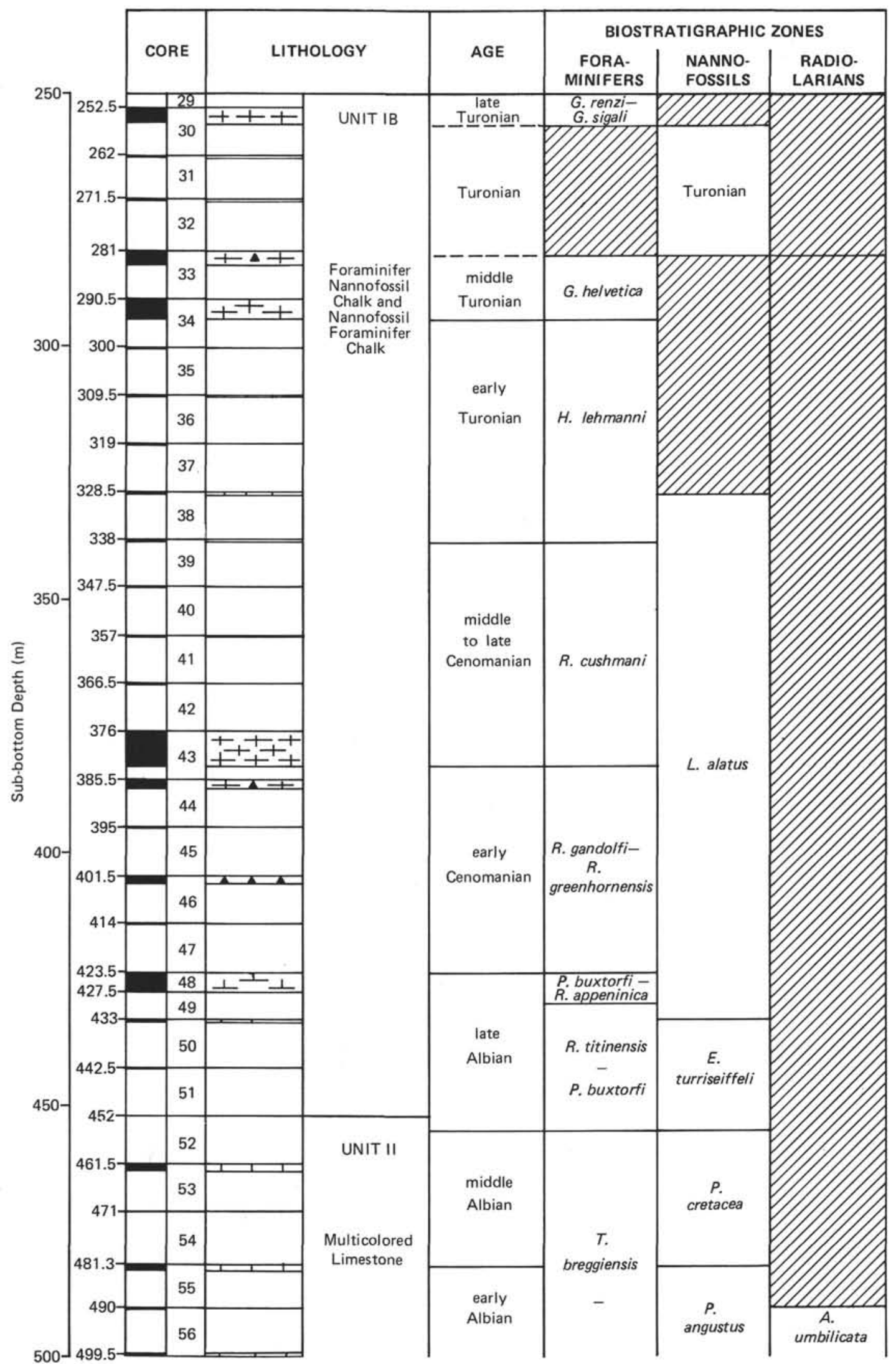

Figure 19. (Continued). 


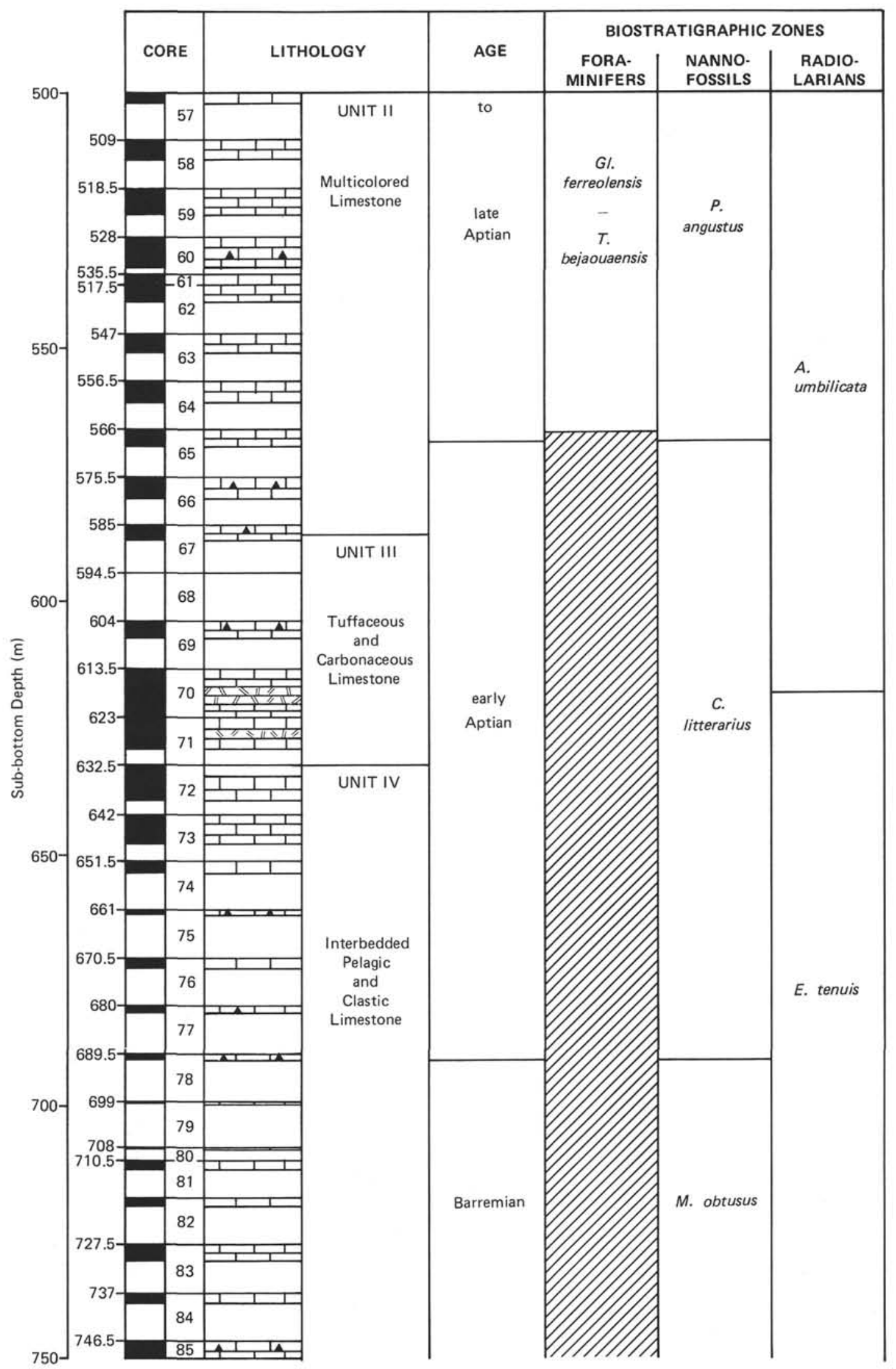

Figure 19. (Continued). 


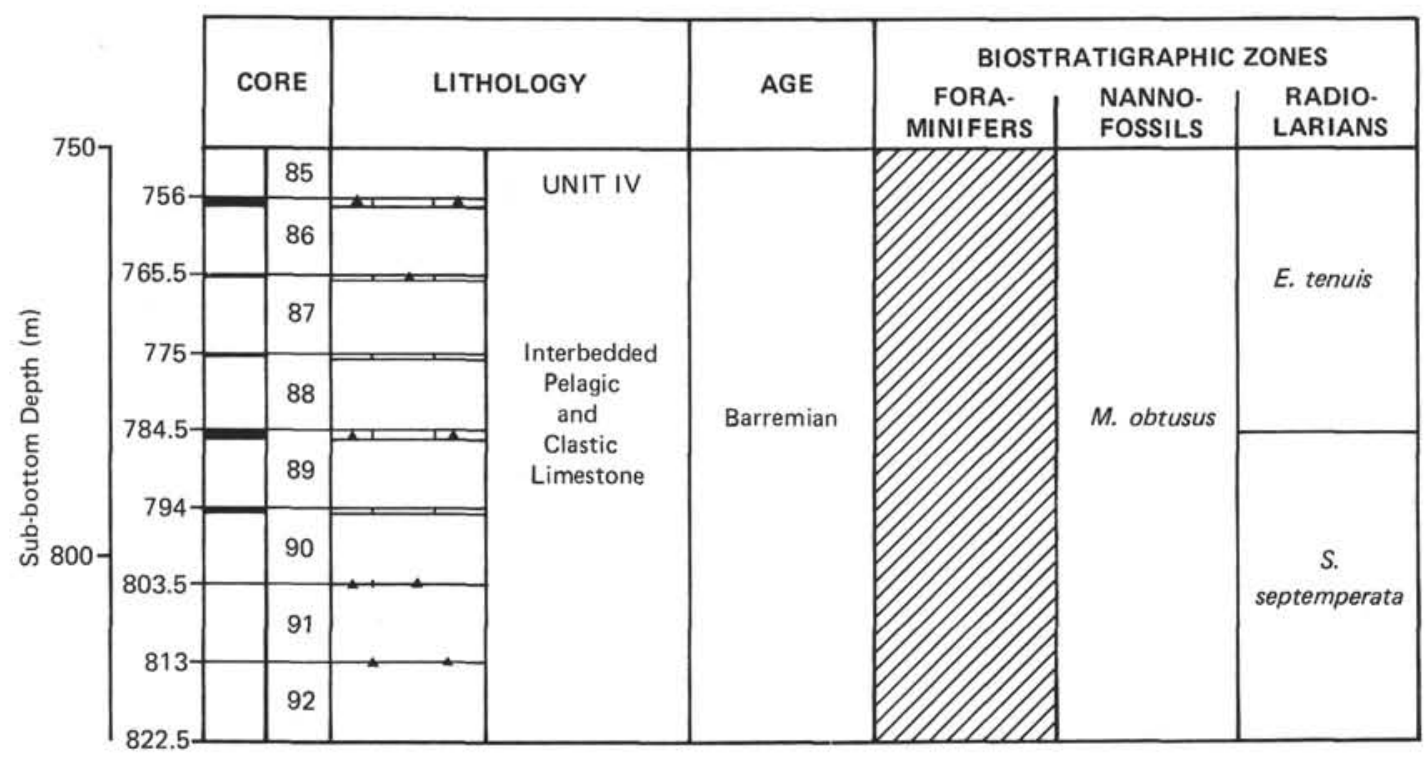

Figure 19. (Continued).

Late Jurassic to Early Cretaceous in age (Larson, 1976). Because of their structurally high position, the western Mid-Pacific Mountains were expected to be a favorable locale for obtaining a thick, homogeneous fossiliferous sediment section for studies of the Mesozoic and Cenozoic paleoenvironments of the central Pacific. It was hoped that the age of the oldest sediments and recovery of basement rocks would help unravel the history of construction, destruction, and subsidence of one of the major aseismic rises which constitutes a fragment of the ancient Mesozoic Pacific Plate. Horizontal movement of the western Mid-Pacific Mountains (Fig. 21) could be documented by studies of microfossils, lithologies, sedimentation rates, and paleomagnetism. Because the eastern segment of the Mid-Pacific Mountains was drilled during DSDP Legs 6, 17, and 32, a location on the western Mid-Pacific Mountains segment was selected for Site 463 of DSDP Leg 62.

\section{Stratigraphic Framework}

The sedimentary sequence recovered from Hole 463 provides a record of carbonate sedimentation from the Early Cretaceous through the Quaternary. A site-summary chart (Fig. 22) presents most of the geochemical, physical-properties, grain-size, and mineralogical data.

The site has been situated above the CCD throughout its history. The Lower Cretaceous (Barremian) to Quaternary sediments have two 16 - to $17-$ m.y. hiatuses that span intervals from the late Maastrichtian through early Eocene and late Oligocene through middle Miocene. A minor hiatus, or condensed section, occurs in the late Coniacian to early Campanian interval.

The sediment section is divided into four major units, based on lithology. From oldest to youngest, these are a Barremian and lower Aptian limestone unit (Unit IV), a mid-Aptian ashy- and carbonaceous-limestone unit (Unit III), an upper Aptian and lower Albian limestone unit (Unit II), and an upper Albian through Quaternary chalk and ooze unit (Unit I). The youngest unit is fur- ther divided into two sub-units, the older is late Albian to late Maastrichtian in age (Sub-unit IB) and the younger is early Eocene to Quaternary in age (Sub-unit IA).

Unit IV, the Barremian and lower Aptian limestone sequence, is more than 190 meters thick. The exact thickness cannot be ascertained, because coring terminated in the unit. The rocks are pelagic limestone and marlstone, interbedded with clastic limestone that contains shallow-water debris, including mollusk, echinoderm, and stromatolite fragments, oolites, rare glauconite, and basalt fragments. Both the frequency of clasticlimestone beds and the maximum sizes of the clasts increase down-section (Fig. 12). The sedimentation rate was high, even though compaction and recrystallization effects have not been accounted for in the calculation (Fig. 20). Nannofossils, poorly preserved and sparse, are not older than Barremian. Foraminifers are absent, probably because of recrystallization. Radiolarians are moderately well preserved, and the lower 20 meters belong to the Sethocapsa trachyostrata Zone, which has been correlated with both Valanginian nannofossils and Barremian foraminifers of DSDP Sites 306 and 307.

At least two reversed-polarity intervals have been identified in the early Aptian. Chiastozygus litterarius nannoplankton zone, in sediment Units III and IV, which may correlate with anomaly M0, or with a reversed-interval identified at DSDP Hole 361. The lowermost sediments are thought to be Barremian, (about 118 m.y. old) based on nannofossil and sedimentation-rate data. Strong seismic reflectors, as observed on air-gun seismic-reflection profiles, occur throughout this unit (Fig. 7). Average velocities $\left(V_{\mathrm{p}}\right)$ are $3.63 \mathrm{~km} / \mathrm{s}$ for the section below 670 meters, and $2.89 \mathrm{~km} / \mathrm{s}$ from 630 to 670 meters (Fig. 17).

Unit III is a 45-meter-thick, lower Aptian cyclic limestone unit that contains abundant volcanic ash and a sequence of organic-rich limestones. The volcanic ash and carbonaceous limestones are superimposed on an 


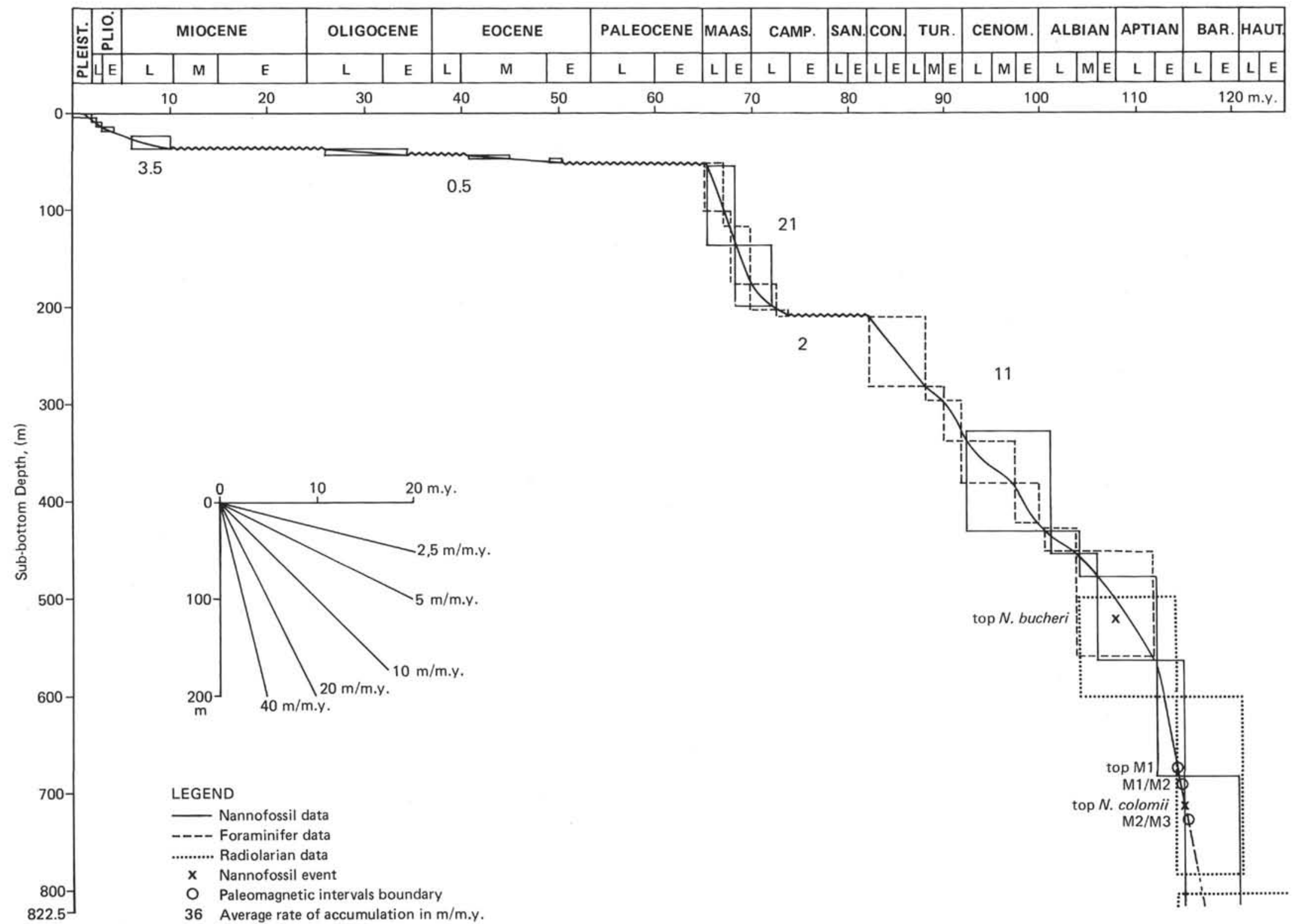

Figure 20. Sedimentation-rate curve for Site 463. 
Table 4. Thicknesses and sedimentation rates at Site 463 .

\begin{tabular}{lccc}
\hline \multicolumn{1}{c}{ Series/Stage } & $\begin{array}{c}\text { Sub-bottom } \\
\text { Depth of Lower } \\
\text { Boundary } \\
(\mathrm{m})\end{array}$ & $\begin{array}{c}\text { Thickness } \\
(\mathrm{m})\end{array}$ & $\begin{array}{c}\text { Average } \\
\text { Sedimentation } \\
\text { Rate } \\
(\mathrm{m} / \mathrm{m} . \mathrm{y} .)\end{array}$ \\
\hline Pleistocene-upper Miocene & 34 & 34 & 3.5 \\
Oligocene-Eocene & 46.8 & 12.8 & 0.5 \\
Maastrichtian & 176.5 & 129.7 & 52 \\
Campanian & 214.5 & 38 & 5 \\
Santonian & 224 & 9.5 & 6 \\
Coniacian & 262 & 38 & 10 \\
Turonian & 290.5 & 28.5 & 5 \\
Cenomanian & 433 & 142.5 & 18 \\
Albian & 528 & 95 & 12 \\
Aptian & 718 & 190 & 27 \\
Barremian & 822.5 & 104.5 & 36 \\
\hline
\end{tabular}

alternating cyclic limestone unit similar to the overlying unit. The almost complete disappearance of volcanicash beds marks the boundary between Units III and IV. The organic-rich zone, confined to Cores 70 and 71 , at depths of 613 to 623 meters, has a maximum organiccarbon content of about $7 \%$. Chert occurs in the unit, but is relatively rare. Foraminifers are absent, but both nannofossils and radiolarians are present. The nanno- fossils are poorly preserved, but readily identifiable. Radiolarians are reworked and are found in sand layers; part of the radiolarian fauna is probably displaced. The calibration of radiolarian zones to the absolute time scale and to calcareous-fossil zonations is poorly documented at present. Physical properties reflect the volcanic and organic-carbon constituents of the sediment. Velocities $\left(V_{\mathrm{p}}\right)$ are low, with a mean of about $2.76 \mathrm{~km} / \mathrm{s}$ (Fig. 17).

Unit II, the lower Aptian to lower Albian pelagic limestone, is 136 meters thick and represents about 9 m.y. of deposition. A notable characteristic of this unit is its several pastel colors, which seem to alternate in cycles. Contacts between cycles or colors are both gradational and sharp, although most are gradational and burrowed. Graded beds are rare and made up entirely of microfossils, with foraminifers and radiolarians at the base and calcareous nannofossils at the top. Chert is a common component. Radiolarians are reworked and occur only in sand layers. Internal molds consist of iron oxides down to Core 63, and below that core of pyrite. Above Core 56, radiolarians are absent. Foraminifers are rare and poorly preserved; nannofossils are common

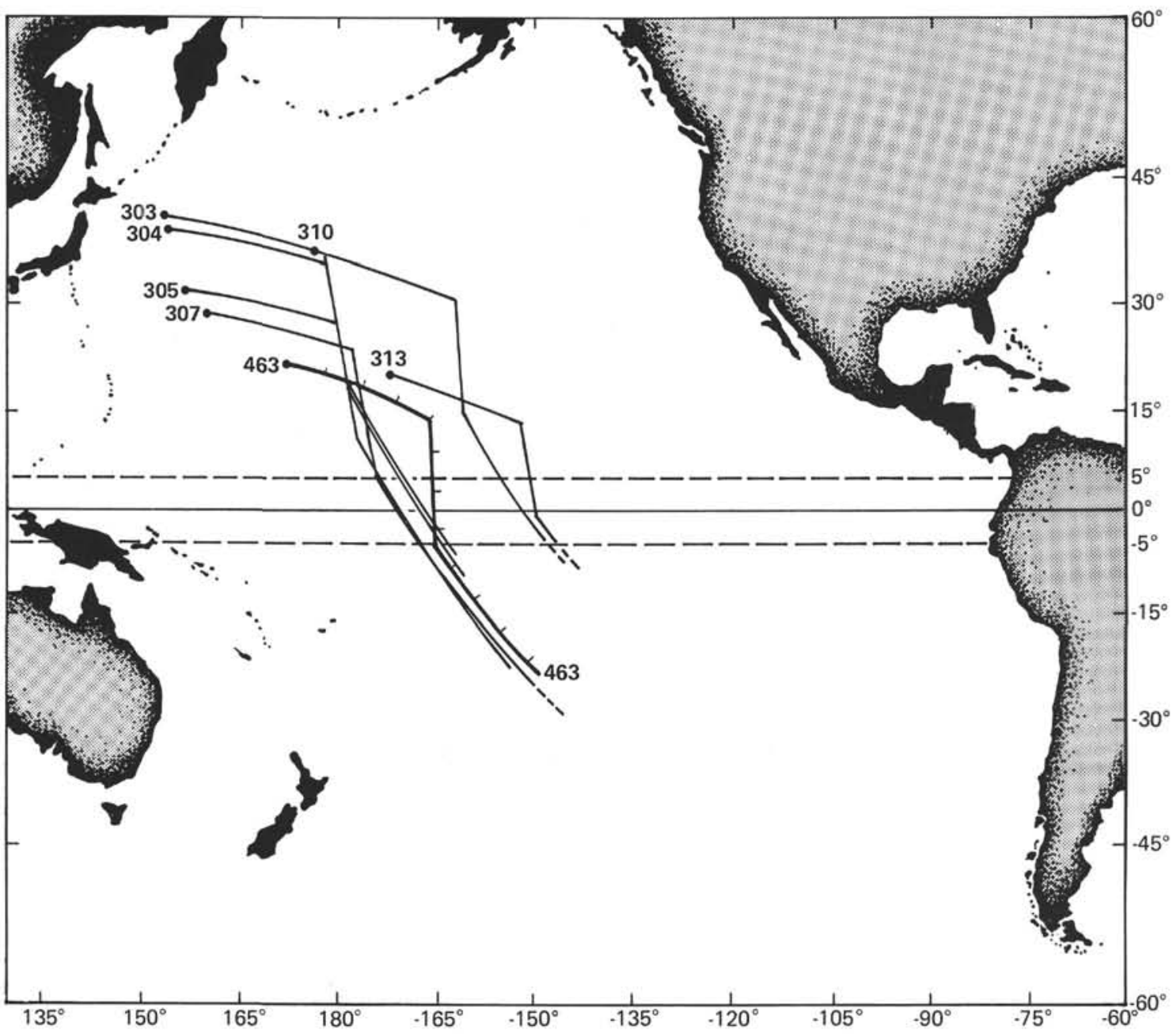

Figure 21. Paths back-tracked through geologic time (10-m.y. increments) for DSDP Leg 32 drill sites and Site 463, according to the rotation model of the Pacific Plate described by Lancelot and Larson (1975). 


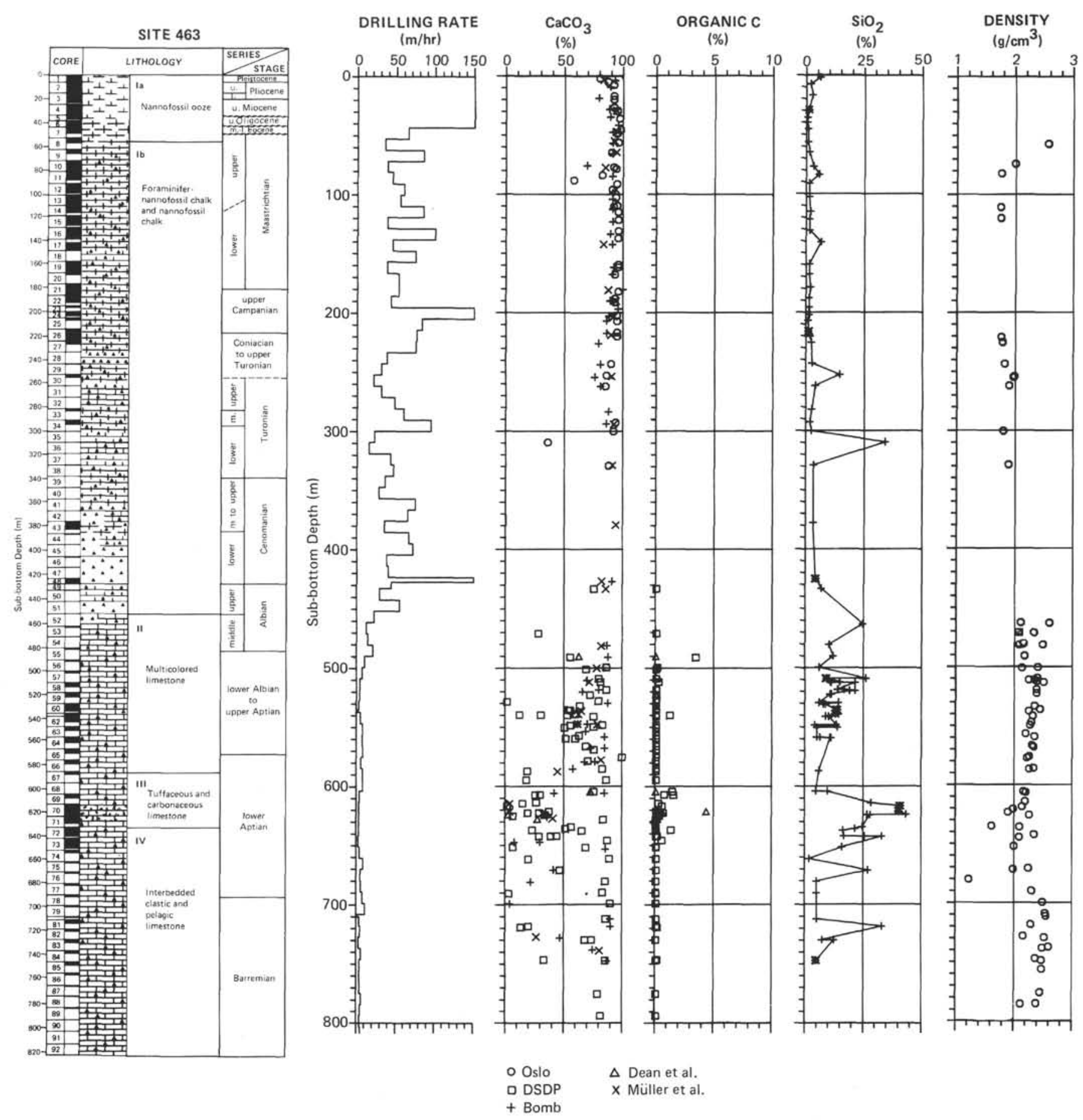

Figure 22. Site-summary chart, Site 463, western Mid-Pacific Mountains. The data for the summary are compiled from the following sources: $\%$ $\mathrm{CaCO}_{3}$ and $\%$ organic carbon from Dean (this volume); density, $\%$ porosity, water content (\% water), and sound velocity from Appendix D (this chapter) and Fujii (this volume); \% sand, silt, and clay from Appendix E (this chapter); and clay mineralogy from Appendix C (this chapter) and Nagel and Schumann (this volume).

to rare, and also poorly preserved. Sedimentation rates are relatively low $(\sim 15 \mathrm{~m} / \mathrm{m} . \mathrm{y}$.) compared with those of the underlying units. The top of this unit marks a major acoustic boundary that shows up as a very strong reflector on air-gun seismic-reflection profiles (Fig. 17). Velocities $\left(V_{\mathrm{p}}\right)$ measured in the laboratory average about $3.14 \mathrm{~km} / \mathrm{s}$.
Nannofossil foraminifer chalk and foraminifer nannofossil chalk are the major lithologies of Unit IB, which makes up 405 meters of late Albian to late Maastrichtian age sediment ( 103-67 m.y.). Rare chert, porcellanite, and limestone constitute parts of the stratigraphic sequence. The chalk is very uniform, mostly stark white, with some mottling, burrows, and 

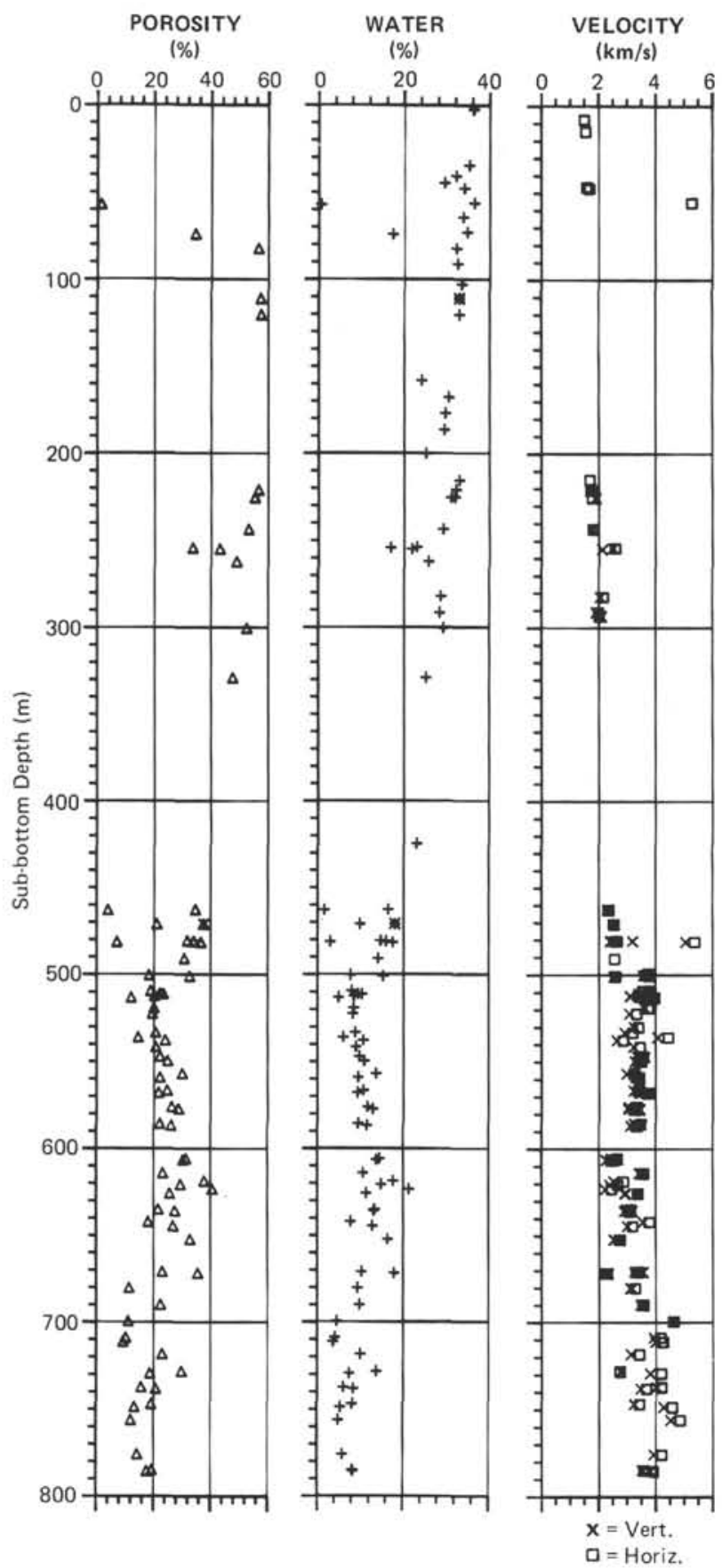
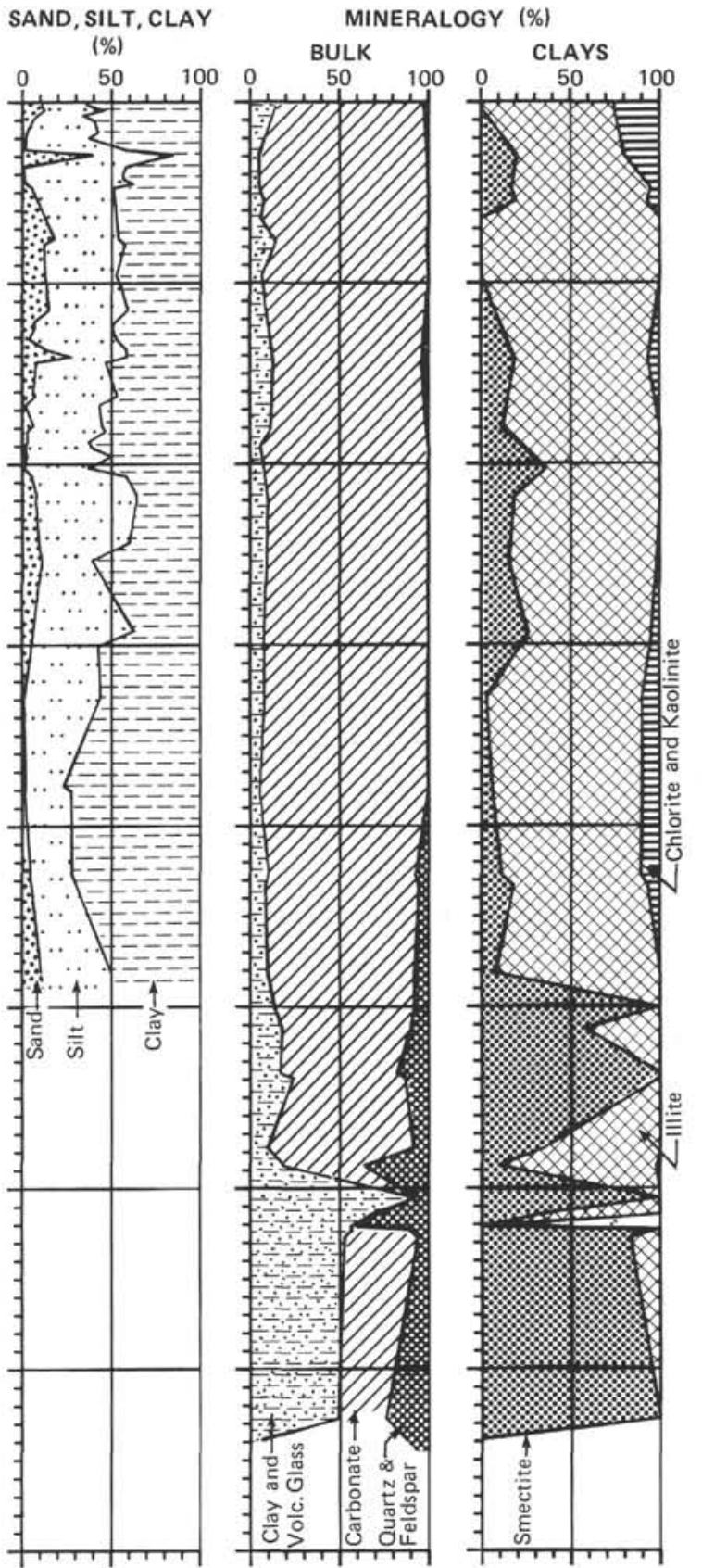

Figure 22. (Continued).

laminations. Foraminifers are well preserved in Santonian through upper Maastrichtian sediments, and are moderately well preserved in the older part of this unit. Nannofossils are abundant to common, and most are poorly preserved. Certain key species are absent in sediments of late Turonian to late Campanian age. Radiolarians are absent. The top of the unit is marked by a 17-m.y. late Maastrichtian to early Eocene hiatus. Sedimentation rates from late Albian to early Santonian averaged about $15 \mathrm{~m} / \mathrm{m} . y$., followed by a late Conacian to middle Campanian hiatus. Rates abruptly increased during the late Campanian and early Maastrichtian to about $42 \mathrm{~m} / \mathrm{m}$.y. This increased rate probably corre- sponds to the equatorial crossing of the site (Lancelot and Larson, 1975), and in small part to an influx of displaced shallow-water components. Sound velocity $\left(V_{\mathrm{p}}\right)$ measurements on individual samples averaged 1.73 $\mathrm{km} / \mathrm{s}$, which agrees well with the interval velocity measured on the air-gun seismic reflection profiles.

The top unit of Hole 463, Unit IA, is 47 meters thick and spans the early Eocene to Pleistocene (about 50 m.y.). The sediment is mainly nannofossil ooze with varying amounts of foraminifers. The sequence is greatly condensed; a major hiatus of about $16 \mathrm{~m} . \mathrm{y}$. occurs in the latest Oligocene through middle Miocene interval, separating 13 meters of Paleogene ooze from 34 
meters of Neogene ooze. A hiatus may occur between the Eocene and Oligocene strata. Nannofossils are well preserved in the Neogene, and moderately well preserved in the Paleogene. An extraordinary abundance of discoasters occurs in the upper Miocene and Pliocene assemblages. Planktonic foraminifers are moderately well to poorly preserved in the Neogene and Oligocene, and well preserved in the Eocene. Siliceous microfossils are absent from the Paleogene, when sedimentation rates averaged only about $0.5 \mathrm{~m} / \mathrm{m}$.y. The slow deposition in part may be caused by short-time hiatuses. Sedimentation rates averaged about $3.5 \mathrm{~m} / \mathrm{m} . \mathrm{y}$. in the late Miocene to Pleistocene, and all calcareous-microfossil zones are present. Sound velocities $\left(V_{\mathrm{p}}\right)$ of individual samples average about $1.53 \mathrm{~km} / \mathrm{s}$ and agree well with the expected interval velocity calculated from seismicreflection profiles.

\section{Post-Depositional Changes}

Major post-depositional (diagenetic) changes in the sediment column involved calcium carbonate changing from biogenic ooze through chalk to limestone, silica changing through porcellanite to chert, and alteration of volcanic ash to smectite and other clay minerals.

Carbonate diagenesis at Site 463 apparently reflects the normal progression from ooze to chalk to limestone, similar to that outlined by Schlanger and Douglas (1974). Microscope evidence shows a major reduction in calcareous microfossils with depth, a reduction in porosity with depth, and the development of cement and overgrowths on undissolved microfossils. This diagenesis is also reflected by changes of physical properties with depth. Major changes in carbonate diagenesis are apparent at about 250 meters, where some chalk beds have been transformed to limestone, and at about 450 meters (between Units I and II), where most chalk has been converted to limestone.

Silica diagenesis is evident throughout most of the Cretaceous strata in Hole 463. All graduations from siliceous limestone to porcellanite to chert are evident. Significant changes can be observed from microscope studies, including replacement of calcite by silica minerals, void filling, and recrystallization of radiolarians (Fig. 12). Diagenesis has not followed a simple progression, as outlined by Wise and Weaver (1974); rather, it seems to have been influenced more by the lithologies and mineralogies of the sediment (Lancelot, 1973) and by burrows (Hein et al., this volume).

Lithologic Unit III contains organic-rich limestone and volcanic ash. The organic-carbon content of one sample is over $7 \%$. The volcanic ash has changed in part to clay, probably caused by a glass-to-smectite conversion.

Physical properties of the sediments reflect the diagenetic changes. Density and sound velocity increase with lithification, whereas porosity decreases. The oozechalk-limestone transitions show the progressive changes well. Ooze has high porosity $(50-70 \%)$, low density $\left(1.5-1.7 \mathrm{~g} / \mathrm{cm}^{3}\right)$, and low velocity $(1.53 \mathrm{~km} / \mathrm{s})$. Chalk has lower porosity (45-60\%), higher density (1.7-2.0 g/ $\left.\mathrm{cm}^{3}\right)$, and higher velocity $(1.7-1.9 \mathrm{~km} / \mathrm{s})$. Limestone in lithologic Unit 4 has high density $\left(2.1-2.4 \mathrm{~g} / \mathrm{cm}^{3}\right)$ and high velocities $(2.9-3.6 \mathrm{~km} / \mathrm{s})$. Limestone in Unit 3, with its included volcanic ash and organic carbon, has a density of almost $2.2 \mathrm{~g} / \mathrm{cm}^{3}$ and a velocity of $2.76 \mathrm{~km} / \mathrm{s}$, values significantly lower than those in both underlying and overlying limestones. The acoustic stratigraphy reflects the diagenetic changes, as shown by Schlanger and Douglas (1974). Prominent reflectors occur at ooze/ chalk and chalk/limestone transitions, and possibly where thick chert beds are present.

\section{Depositional History of the Western Mid-Pacific Mountains from Early Cretaceous to Recent Times}

The litho- and biostratigraphic framework obtained from the sediment column penetrated at Site 463 allows us to describe the evolution of the depositional environment in the wesern Mid-Pacific Mountains. At present, the age of the Mid-Pacific Mountains is not well known (Larson, 1976). However, the oldest sediments at Site 463 are of Barremian age, approximately 20 m.y. older than those overlying basaltic rocks at Site 171 (Winterer, Ewing, et al., 1973), and approximately 40 m.y. older than those overlying the volcanic basement at Site 313 (Larson, Moberly, et al., 1975). It is clear, therefore, that the structural high of the western Mid-Pacific Mountains is considerably older than previously believed. Comparison with the results obtained at the other sites, where basement rocks have been reached after penetrating the entire sediment column (Fig. 1), makes it clear that the Mid-Pacific Mountains represent a complex structural high whose segments have been built or added to by volcanic events stretching over the extraordinarily long time of at least $40 \mathrm{~m} . \mathrm{y}$.

It is difficult to reconstruct the paleodepth of the oldest deposits at Site 463 because they consist of pelagic limestones interbedded with layers rich in clastic calcareous components (Fig. 13), probably displaced from contemporary neritic environments nearby. Shallow-water fossil assemblages dredged from the flanks of several guyots in the Mid-Pacific Mountains (Hamilton, 1956; Lonsdale et al., 1972) support the idea that many of the submarine volcanoes which surmount this platform were tropical islands surrounded by reefs or carbonate banks during parts of the Early and Late Cretaceous. These deposits, probably close to the coast lines of the ancient volcanic islands, plus the shape and size of the largest components in the detrital limestones, suggest that the source for this material was close by, probably the flat-topped seamount which was crossed during the approach to the site (Fig. 7; Rea et al., this volume).

Because all shallow-water components are apparently displaced, they do not offer direct evidence for the paleodepth of their host strata. The associated pelagic limestones unfortunately lack any fossil evidence of abundant benthic fauna (except large burrows). Because it is known that diverse mollusk faunas populated the flanks of adjacent guyots down to several hundreds of meters water depth (Kauffman, 1976), we assume that these limestones were laid down in intermediate water depths. The rapidly diminishing sedimentation rates (Fig. 20), the decreasing number of layers with displaced 
material, and the decreasing size of the reworked limestone clasts (Fig. 12) in successively younger sediments indicate that the depositional paleoenvironment at Site 463 deepened rapidly during late Barremian and early Aptian time.

During an approximately 2-m.y. interval in Aptian time (about $112-113 \mathrm{~m} . \mathrm{y}$. ago) ashes, which occur as dark readily discernible horizons in the pelagic deposits, mark a period of extensive volcanic activity, which may be contemporaneous with the generation of the volcanic basement of the eastern Mid-Pacific Mountains (Winterer, Ewing, et al., 1973).. In part of this interval, the greenish-black and greenish-gray volcanic ashes are intercalated with greenish-black to olive-black limestones and marly clays. The extraordinarily high organiccarbon content and the lamination of several intervals in these rocks (Fig. 10) suggest the development of an oxygen-poor depositional environment. Although most of this interval reveals signs of benthic life, several horizons with thin laminations suggest that the interface between reducing and oxidizing environments coincided with the benthic boundary, or even that it moved into the overlying water masses. Because well-oxygenated sediments of the same age have been sampled elsewhere in the deep Pacific basins (Schlanger and Jenkyns, 1976), the possibility of an ocean-wide euxinic paleoenvironment in the mid-Cretaceous Pacific can be excluded. Although the development of an oceanic midwater oxygen minimum has been suggested as a possible cause for the widespread occurrence of anoxic lithofacies not only in the Pacific, but also in the Indian and Atlantic Oceans, the coincidence of the oxygen-poor paleoenvironment with significant Early Cretaceous volcanism in the western equatorial Pacific, as observed in the Mid-Pacific Mountains and other locations, requires further investigation.

After cessation of volcanic activity during the Aptian, deposition of calcareous sediments continued as the site slowly subsided. The pink, pale-green, greenishgray, brown, and white limestones with their frequent and apparently cyclic color changes, the graded coarser beds enriched in foraminifers and radiolarians at their bases, and the wavy laminations document a period of pelagic sedimentation at this site (Fig. 9). It is particularly interesting to note that the guyots adjacent to Site 463 no longer contributed shallow-water debris, as the displaced material consists entirely of siliceous and calcareous remains of fossil plankton.

The thick interval of Upper Cretaceous calcareous ooze and chalk (more than $400 \mathrm{~m}$ ) with extraordinarily well-preserved microfossils represents the time when this site passed under the high-productivity zone of the equatorial current system (Fig. 21). Important changes in the sedimentation rates of the dominantly pelagic biogenic deposits suggest that major fluctuations of this current regime were not restricted to the Cenozoic (van Andel et al., 1975), but that they occurred during late Mesozoic times as well.

The calcareous-ooze sequence deposited during the Cenozoic at Site 463 is unexpectedly thin and incomplete. This interval, less than 50 meters thick, includes long hiatuses spanning the late Oligocene to middle Miocene and late Maastrichtian to middle Eocene, whereas the condensed sections between these hiatuses and deposits younger than middle Miocene are typical examples of sediments laid down at intermediate water depths, well above the CCD, under the oligotrophic central subtropical water masses of the North Pacific. The hiatuses are the result of major revolutions of the intermediate water masses, which lead not only to hiatuses, but also to the widespread occurrence of reworked pelagic fossils of Miocene, Oligocene, Eocene and Late Cretaceous age. The upper Miocene and Pliocene nannofossil oozes consist almost entirely of discoasters; it is not yet clear whether this peculiar composition is the result of specialized algal floras in the oligotrophic central subtropical North Pacific surfacewater masses, or the result of selective dissolution of the smaller coccoliths and (or) of mechanical separation of the biogenic sediment components.

\section{Highlights of the Site $\mathbf{4 6 3}$ Coring Record}

1. Recovery of Barremian to Quaternary sediments document a 118-m.y. history of the western Mid-Pacific Mountains, which once reached above the sea surface but have subsided to 2 to $3 \mathrm{~km}$ water depth.

2. Horizons with displaced shallow-water carbonate components interbedded with pelagic limestone of Barremian and early Aptian age document the presence of a shallow-water carbonate environment in the Mid-Pacific Mountains.

3. Penetration of a lower Aptian sequence of volcanic ashes, clays, and carbonaceous limestones which are in part intensely laminated, indicating a series of paleoceanographic events resulting in deep-sea sediments with high organic-carbon concentrations.

4. Recovery of volcanic ashes which date the Early Cretaceous eruptive events in the western Mid-Pacific Mountains.

5. Successful construction of an Early Cretaceous biostratigraphic framework.

6. Recovery of an expanded calcareous Upper Cretaceous sedimentary section with uniquely well-preserved foraminifer and nannofossil taphocoenoses.

7. Penetration of an unexpectedly thin, partly condensed, and incomplete Cenozoic section with horizons where calcareous fossil assemblages are severely affected by dissolution.

8. Correlation of the seismic reflectors to chalk, chert, and limestone interfaces by means of sediment physical properties. The absence of Cenozoic chert layers and the condensed and fragmentary Cenozoic record of Site 463 were unexpected.

\section{REFERENCES}

Chase, T. E., Menard, H. W., and Mammerickx, J., 1971. Topoggraphy of the North Pacific: La Jolla (Univ. Calif.).

Foreman, H. P., 1975. Radiolaria from the North Pacific, Deep Sea Drilling Project, Leg 32. In Larson, R. L., Moberly, R., et al., Init. Repts. DSDP, 32: Washington (U.S. Govt. Printing Office), 579-670.

Hamilton, E. L., 1956. Sunken islands of the Mid-Pacific Mountains. Geol. Soc. Am. Mem., 64. 
Heezen, B. C., Fischer, A. G., et al., 1971. Site 44. In Fischer, A. G., Heezen, B. C., et al., Init. Repts. DSDP, 6: Washington (U.S. Govt. Printing Office), 17-39.

Kauffman, E. G., 1976. Deep-sea Cretaceous macrofossils: Hole 317A, Manikiki Plateau. In Schlanger, S. O., Jackson, E. D., et al., Init. Repts. DSDP, 33: Washington (U.S. Govt. Printing Office), 33:503-535.

Keating, B. H., and Helsley, C. E., 1978. Magnetostratigraphy of Cretaceous age sediments from Sites 361,363 , and 364 . In Bolli, H. M., Ryan, W. B. F., et al., Init. Repts. DSDP, 40: Washington (U.S. Govt. Printing Office), 459-468.

Lancelot, Y., 1973. Chert and silica diagenesis in sediments from the Central Pacific, In Winterer, E. L., Ewing, J. I., et al., Init. Repts. DSDP, 17: Washington (U.S. Govt. Printing of fice), 377-405.

Lancelot, Y., and Larson, R. L., 1975. Sedimentary and tectonic evolution of the northwestern Pacific. In Larson, R. L., Moberly, R., et al., Init. Repts. DSDP, 32: Washington (U.S. Govt. Printing Office), 925-939.

Larson, R. L., 1976. Late Jurassic and Early Cretaceous evolution of the western central Pacific Ocean. J. Geomagnet. Geoelec., 28:219-239.

Larson, R. L., Moberly, R., et al., 1975. Site 313: Mid-Pacific Mountains. In Larson, R. L., Moberly, R., et al., Init. Repts. DSDP, 32: Washington (U.S. Govt. Printing Office), 313-390.

Lonsdale, P., Normark, W. R., and Nowman, W. A., 1972. Sedimentation and erosion on Horizon Guyot. Geol. Soc. Am. Bull., $83: 289-316$.
Marshall, N., 1975. Petrology and structural composition of basaltic rock recovered on Leg 32, Deep Sea Drilling Project. In Larson, R. L., Moberly, R., et al., Init. Repts. DSDP, 32: Washington (U.S. Govt. Printing Office), 563-570.

Saito, K., and Ozima, M., 1973. K-Ar ages of six DSDP Leg 17 samples. Rock Magnet. Paleogeophys., 1:98-101.

Sayles, F. L., Manheim, F. T., and Waterman, L. S., 1973. Interstitial water studies on small core samples, Leg 15. In Heezen, B. C., MacGregor, I. D., et al., Init. Repts. DSDP, 20: Washington (U.S. Govt. Printing Office), 783-805.

Schlanger, S. O., and Douglas, R. G., 1974. The pelagic ooze, chalk, limestone transition and its implications for marine stratigraphy. Internat. Assoc. Sedimentol. Spec. Publ., 1:117-148.

Schlanger, S. O., and Jenkyns, H. C., 1976. Cretaceous oceanic anoxic events: causes and consequences. Geol. Mijnb., 55:179-184.

van Andel, Tj. H., Heath, G. R., and Moore, T. C., 1975. Cenozoic history and paleoceanography of the central Equatorial Pacific Ocean. Geol. Soc. Am. Mem., 143.

Winterer, E. L., 1976. Anomalies in the tectonic evolution of the Pacific. Am. Geophys. Union, 19:269-278.

Winterer, E. L., Ewing, J. I., et al., 1973. Site 171. In Winterer, E. L., Ewing, J. I., et al., Init. Repts. DSDP, 17: Washington (U.S. Govt. Printing Office), 283-334.

Wise, S. W., and Weaver, F. M., 1974. Chertification of oceanic sediments. Internat. Assoc. Sedimentol, Spec. Publ., 1:301-326. 
APPENDIX A

Smear-Slide Summary, Site 463

SITE 463

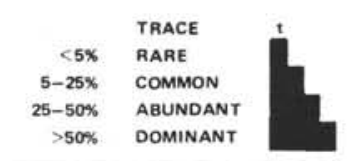

* = minor lithology

\begin{tabular}{|c|c|c|c|}
\hline SAMPLE & BIOGENIC COMPONENTS & NON-BIOGENIC COMPONENTS & AUTHIGENIC COMPONENTS
\end{tabular}

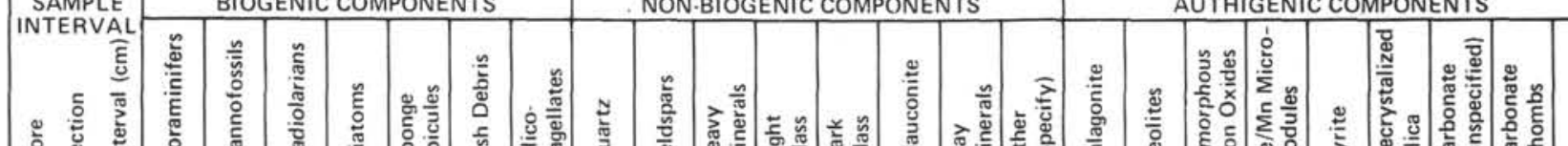

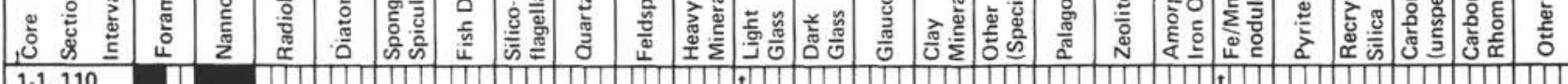

$1.1,110$

$1 \cdot 3,70$

$1 \cdot 4,70$

$2 \cdot 1,70$

$2-1,135$

2.2, 20

$2 \cdot 2,110$

$2 \cdot 3,100$

$2-4,100$

$2 \cdot 5,100$

2.6, 80

$2 \cdot 7,25$

$3 \cdot 1,100$

$3 \cdot 2,100$

$3 \cdot 3,100$

$3-4,100$

$3 \cdot 5,100$

$3 \cdot 6,40$

$3, \mathrm{CC}$

$4-1,100$

$4 \cdot 2,100$

$4 \cdot 2,130$

$4 \cdot 3,100$

$4.4,100$

$4.5,100$

$4-6,100$

4, CC

$5 \cdot 1,100$

$5-2,100$

$5, \mathrm{CC}$

6-1, 100

6-2, 100

$6-3,100$

$6-4,100$

6.6, 11

6.6,30

$7 \cdot 1,100$

$7 \cdot 1,149$

*7.2, 19

7.2, 100

$7 \cdot 3,20$

$7.3,40$

$7-4,20$

$7, \mathrm{CC}$

$8 \cdot 1,100$

$8.2,40$

$8 \cdot 2,115$

$9-1,20$

$9.1,79$

9-2, 71

9-3,40

$10-1,20$

$10 \cdot 1,135$

$10.2,50$

$10-3,60$

$10-6,4$

$10-6,60$

$11.1,100$

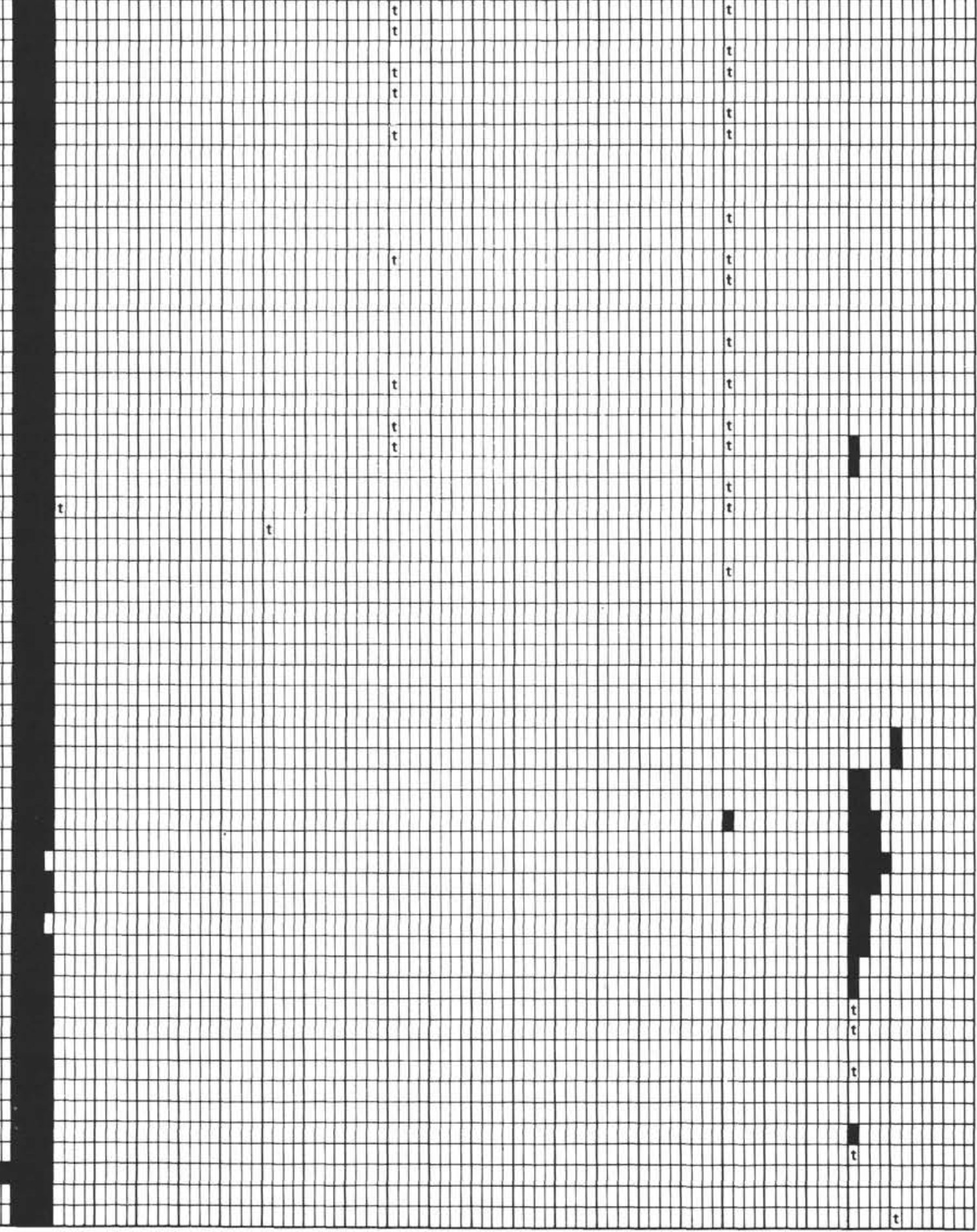


Appendix A. Continued.

SMEAR SLIDE SUMMARY

SITE 463

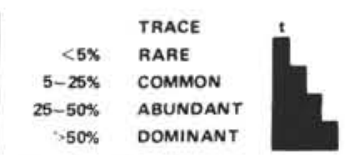

- minor lithology

\begin{tabular}{|c|c|c|c|c|c|c|c|c|c|c|c|c|c|c|c|c|c|c|c|c|c|c|c|c|c|c|}
\hline \multirow[b]{2}{*}{ 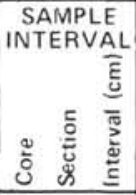 } & \multicolumn{7}{|c|}{ BIOGENIC COMPONENTS } & \multicolumn{8}{|c|}{ NON-BIOGENIC COMPONENTS } & \multicolumn{11}{|c|}{ AUTHIGENIC COMPONENTS } \\
\hline & 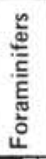 & 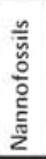 & 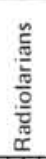 & $\begin{array}{l}\text { E } \\
\stackrel{0}{0} \\
0\end{array}$ & 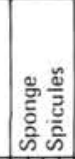 & $\begin{array}{l}\frac{n}{2} \\
\frac{0}{0} \\
\frac{5}{5} \\
\frac{5}{4}\end{array}$ & 兽 & 预 & 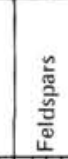 & 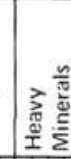 & 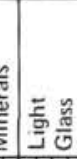 & 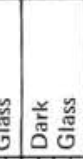 & 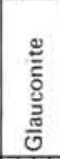 & 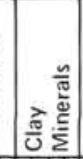 & 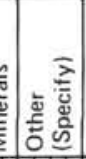 & 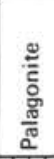 & $\begin{array}{l}\stackrel{\mathscr{W}}{\circ} \\
\text { N }\end{array}$ & 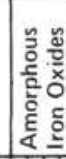 & 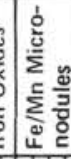 & & 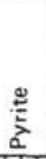 & 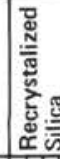 & 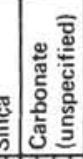 & & 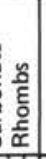 & ఫે \\
\hline $11 \cdot 2,25$ & & & & & & & & & & & & 17 & & 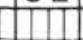 & 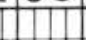 & a & & & & & & & 17 & & & \\
\hline $11.5,75$ & & & & & & & & & & & & & & & & & & & & & & & & & & \\
\hline $12-1,100$ & & & & & & & & & & & & & & & & & & & & & & & & & & \\
\hline $12.4,100$ & & & & & & & & & & & & & & & & & & & & & & & & & & \\
\hline $13 \cdot 1,70$ & & & & & & & & & & & & & & & & & & & & & & & & & & \\
\hline $13-3,70$ & & & & & & & & & & & & & & & & & & & & & & & & & & \\
\hline $13 \cdot 6,70$ & & & & & & & & & & & & & & & & & & & & & & & & & & \\
\hline $14 \cdot 1,100$ & & & & & & & & & & & & & & & & & & & & & & & & & & \\
\hline $14 \cdot 1,100$ & & & & & & & & & & & & & & & & & & & & & & & & & & \\
\hline $14-3,100$ & & & & & & & & & & & & & & & & & & & & & & & & & & \\
\hline$\cdot 14.4,164$ & & & & & & & & & & & & & & & & & & & & & & & & & & \\
\hline $15 \cdot 1,90$ & & & & & & & & & & & & & & & & & & & & & & & & & & \\
\hline $15 \cdot 3,90$ & & & & & & & & & & & & & & & & & & & & & & & & & & \\
\hline $15 \cdot 5,90$ & & & & & & & & & & & & & & & & & & & & & & & & & & \\
\hline $16 \cdot 1,120$ & & & & & & & & & & & & & & & & & & & & & & & & & & \\
\hline $16 \cdot 3,70$ & & & & & & & & & & & & & & & & & & & & & & & & & & \\
\hline $16 \cdot 6,50$ & & & & & & & & & & & & & & & & & & & & & & & & & & \\
\hline $17-1,90$ & & & & & & & & & & & & & & & & & & & & & & & & & & \\
\hline $17 \cdot 3,100$ & & & & & & & & & & & & & & & & & & & & & & & & & & \\
\hline $17-6,90$ & & & & & & & & & & & & & & & & & & & & & & & & & & \\
\hline $18 \cdot 1,5$ & & & & & & & & & & & & & & & & & & & & & & & & & & \\
\hline $19-1,70$ & & & & & & & & & & & & & & & & & & & & & & & & & & \\
\hline $19-3,70$ & & & & & & & & & & & & & & & & & & & & & & & & & & \\
\hline $19.5,50$ & & & & & & & & & & & & & & & & & & & & & & & & & & \\
\hline $20-1,80$ & & & & & & & & & & & & & & & & & & & & & & & & & & \\
\hline $21-2,70$ & & & & & & & & & & & & & & & & & & & & & & & & & & \\
\hline $21-4,70$ & & & & & & & & & & & & & & & & & & & & & & & & & & \\
\hline $22-1,80$ & & & & & & & & & & $t$ & & & & & & & & & & & & & & & & \\
\hline $22 \cdot 3,80$ & & & & & & & & & & & & & & & & & & & & & & $t$ & & & & \\
\hline $22-5,40$ & & & & & & & & & & & & & & & & & & & & & & & & & & \\
\hline $23-1,70$ & & & & & & & & & & & & & & & & & & & & & & H & & & & \\
\hline $24-1,70$ & & & & & & & & & & & & & & & & & & & & & & $t$ & & & & \\
\hline $24 \cdot 3,70$ & & & & & & & & & & & & & & & & & & & & & & & & & & \\
\hline $25 \cdot 1,70$ & & & & & & & & & & & & & & & & & & & & & & & & & & \\
\hline $26 \cdot 2,80$ & & & & & & & & & & & & & & & & & & & & & & 1 & & & & \\
\hline $26-4,80$ & & & & & & & & & & & & & & & & & & & & & & 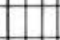 & & & & \\
\hline $26 \cdot 5,35$ & & & & & & & & & & & & & & & & & & & & & & t & & & & \\
\hline $26 \cdot 6,85$ & & & & & & & & & & & & & & & & & & & & & & $t$ & & & & \\
\hline $27 \cdot 1,85$ & & & & & & & & & & & & & & & & & & & & & & & $t$ & & & \\
\hline $29 \cdot 1,70$ & & & & & & & & & & & & & & & & & & & & & & & t & & & \\
\hline $30-1,20$ & & & & & & & & & & & & & & & & & & & & & & & $t$ & & & \\
\hline $30-2,82$ & & & & & & & & & & & & & & & & & & & & & & & t & & & \\
\hline $31-1,33$ & & & & & & & & & & & $t$ & & & & & & & & & & & & & & & \\
\hline $31-1,110$ & & & & & & & & & & & & & & & & & & & & & & & & & & \\
\hline $33-2,40$ & & & & & & & & & & & & & & & & & & & & & & & & & & \\
\hline $34-1,35$ & & & & & & & & & & & & & & & & & & & & & & & & & & \\
\hline $34.1,75$ & & & & & & & & & & & & & & & & & & & & & & & & & & \\
\hline $34 \cdot 3,45$ & & & & & & & & & & & & & & & & & & & & & & & & & & \\
\hline $34 \cdot 3,80$ & & & & & & & & & & & & & & & & & & & & & & & D & & & \\
\hline $35 \cdot 1,20$ & & & & & & & & & & & & & & & & & & & t & & & & & & & \\
\hline $36-1,18$ & & & & & & & & & & & & & & & & & & & & & & & & & & \\
\hline $38 \cdot 1,25$ & & & & & & & & & & & & & & & & & & & & & & & & & & \\
\hline $39, \mathrm{CC}$ & & & & & & & & & & & & & & & & & & & $t$ & & & & $\theta$ & & & \\
\hline $40, \mathrm{CC}$ & & & & & & & & & & & & & & & & & & & & & & & $t$ & + & & \\
\hline $42, \mathrm{CC}$ & & & & & & & & & & & & & & & & & & & & & & & & $t$ & & \\
\hline $43 \cdot 1,75$ & & & & & & & & & & & t & & & & & & & & & $t$ & & & & & & \\
\hline $43 \cdot 3,85$ & & & & & & & & & & & & & & & & & & & & $t$ & & $t$ & & & & \\
\hline $43 \cdot 5,85$ & & & & & & & & & & & & $t$ & & & & & & & & H & & 7 & & & & \\
\hline $44 \cdot 1,82$ & & & & & & & & & & & HO & 010 & & & & & & & & $t$ & & $t$ & & & & \\
\hline
\end{tabular}


Appendix A. Continued.

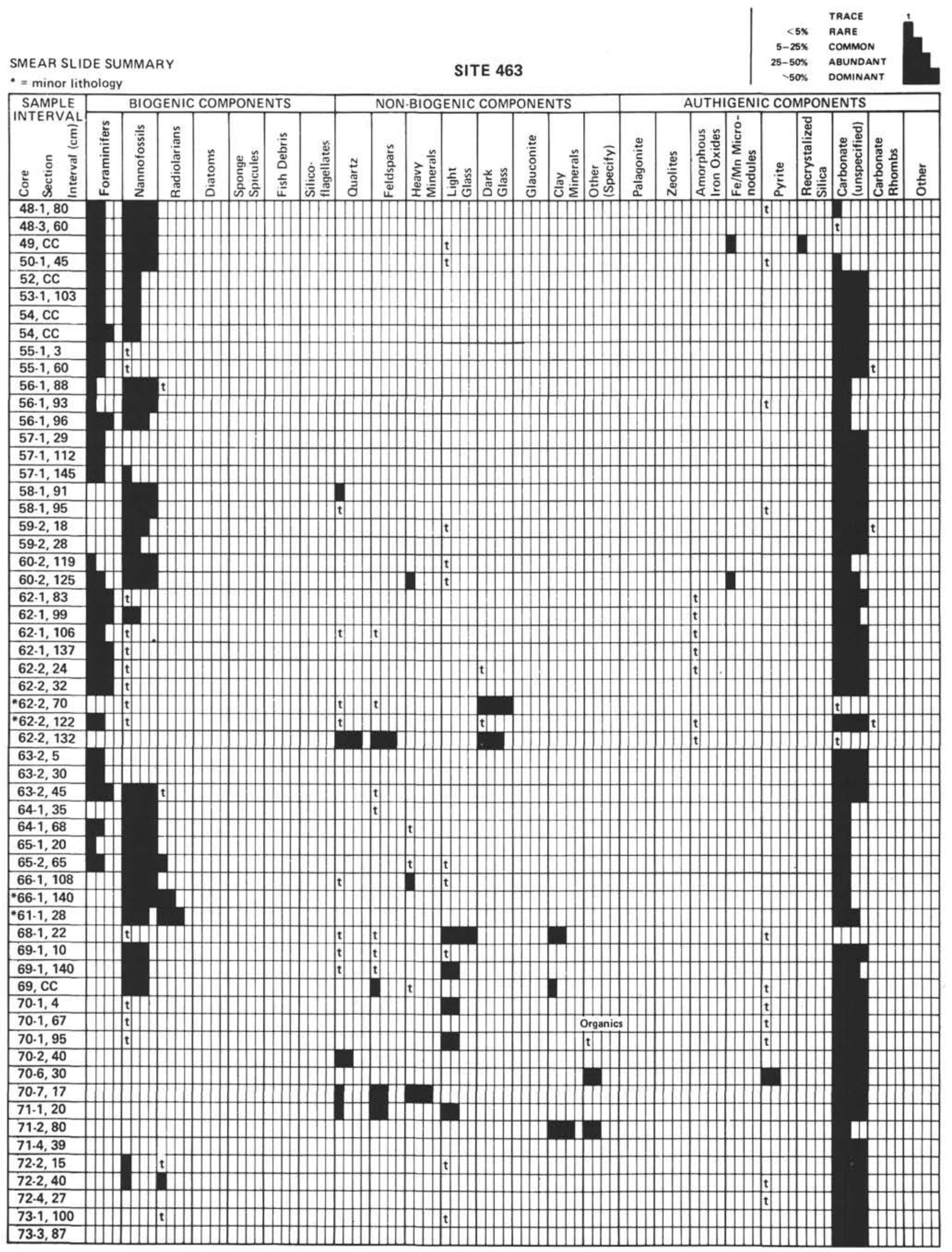


Appendix A. Continued.

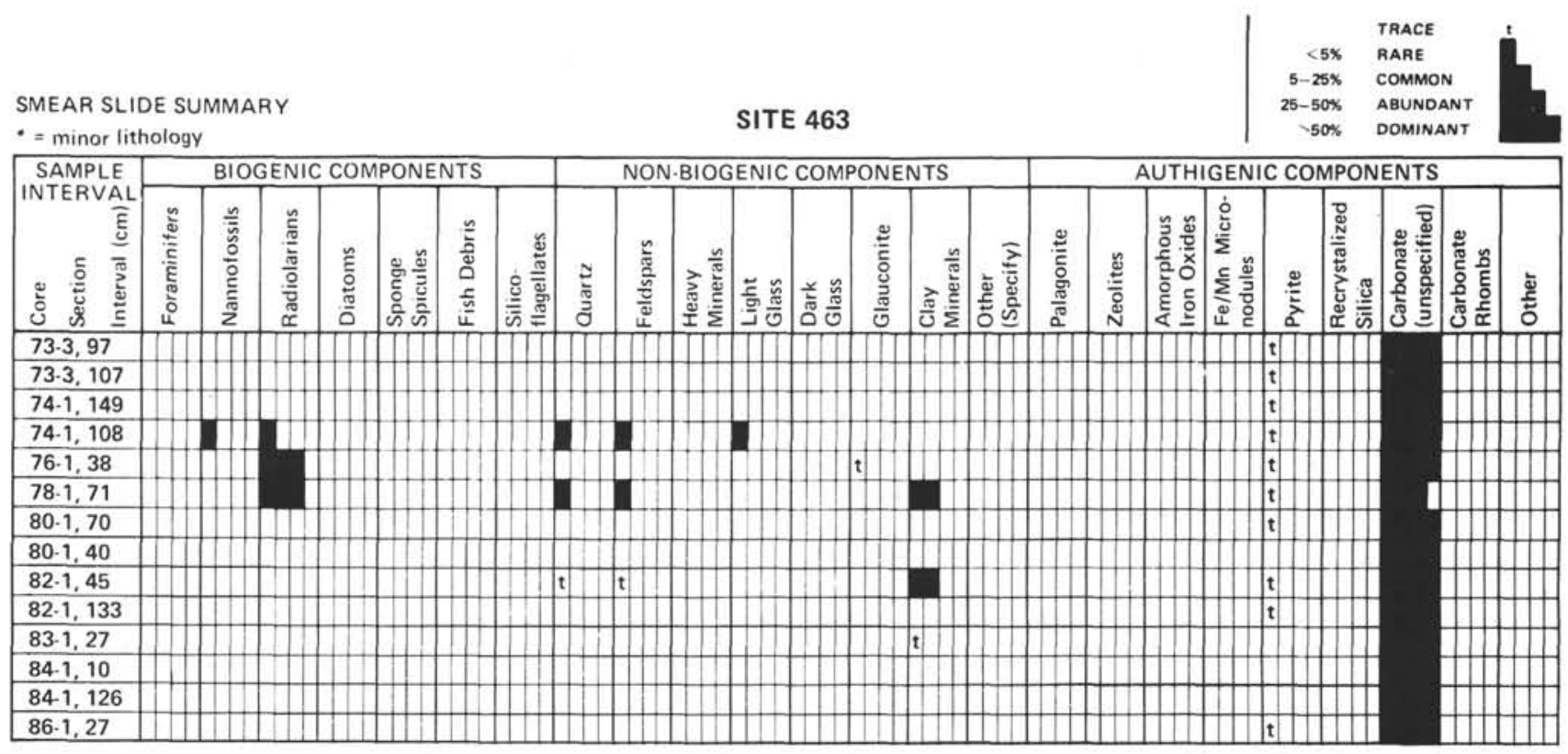

SITE 463
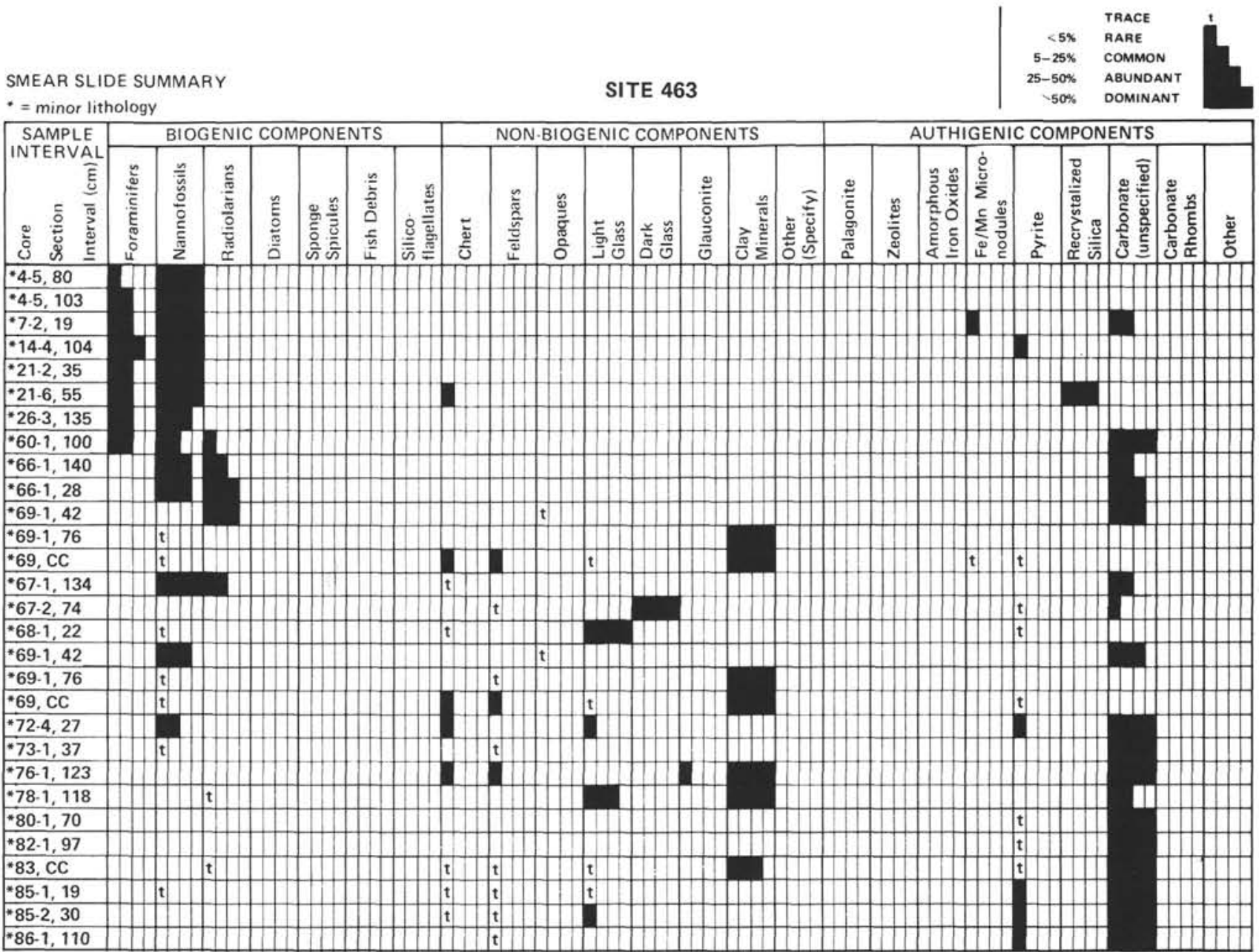
APPENDIX B

Coarse-Fraction Components, Site 463.

\begin{tabular}{|c|c|c|c|c|c|c|c|c|c|c|c|c|c|c|c|c|c|}
\hline \multirow[b]{2}{*}{ Core } & \multirow[b]{2}{*}{ Section } & \multirow[b]{2}{*}{$\begin{array}{l}\text { Interval } \\
(\mathrm{cm})\end{array}$} & \multirow[b]{2}{*}{ Sample } & \multirow{2}{*}{$\begin{array}{l}\text { Sub-bottom } \\
\text { Depth } \\
\text { (m) }\end{array}$} & \multicolumn{8}{|c|}{ Bulk Mineralogy $(\%)$} & \multicolumn{5}{|c|}{ Clay Mineralogy $(\%)$} \\
\hline & & & & & $\begin{array}{c}\text { Clay Minerals } \\
+ \text { Volcanic Glass }\end{array}$ & Quartz & Feldspar & Carbonates & Opal-CT & Pyrite & $\begin{array}{l}\text { Clinoptil- } \\
\text { olite }\end{array}$ & Others & Smectite & Illite & Chlorite & Kaolinite & Others \\
\hline I & 3 & $20-22$ & 1 & 3.21 & 14.1 & 2.6 & - & 83.3 & - & - & - & - & - & 74.5 & 17.9 & 7.6 & - \\
\hline 4 & 4 & $82-84$ & 2 & 29.33 & 4.8 & 1.0 & - & 94.2 & - & $=$ & - & - & 20 & 60.0 & \multicolumn{2}{|c|}{$20^{1}$} & - \\
\hline 7 & 3 & $90-92$ & 3 & 47.41 & 5.1 & $\sim$ & - & 94.9 & - & - & - & - & 17.1 & 77.7 & \multicolumn{2}{|r|}{5.2} & $\mathrm{Cpt}$ \\
\hline 8 & 2 & $35-37$ & 4 & 54.86 & 7.7 & - & - & 92.3 & - & - & - & - & 19.5 & 73.4 & \multicolumn{2}{|r|}{7.1} & $\mathrm{Cpt}$ \\
\hline 9 & 2 & $46-48$ & 5 & 64.47 & 5.8 & - & - & 94.2 & - & - & - & - & - & 100 & - & - & Cpt \\
\hline 10 & 4 & $88-90$ & 6 & 77.39 & 14.4 & 1 & - & 84.6 & - & - & - & - & - & 100 & - & - & $\mathrm{Cpt}$ \\
\hline 12 & 4 & $56-58$ & 7 & 96.07 & 6.4 & - & - & 93.6 & - & - & - & - & - & 100 & - & - & $\mathrm{Cpt}$ \\
\hline 17 & 3 & $83-85$ & 8 & 142.34 & 12.8 & 3.9 & - & 83.3 & - & - & - & - & 18.9 & 74.5 & - & 6.5 & - \\
\hline 21 & 3 & $130-132$ & 9 & 180.81 & 11.5 & 1.3 & - & 87.2 & - & - & - & - & 11.7 & 88.3 & - & - & - \\
\hline 22 & 3 & $110-112$ & 10 & 190.11 & 5.8 & Tr. & - & 94.2 & - & - & - & - & 22.6 & 77.4 & - & - & - \\
\hline 24 & 3 & $61-63$ & 11 & 203.12 & 7.8 & - & - & 92.2 & - & - & - & - & 36.0 & 64.0 & - & - & - \\
\hline 26 & 3 & $124-126$ & 12 & 218.75 & 9.8 & 0.5 & - & 89.7 & - & - & - & - & 18.4 & 81.6 & - & - & - \\
\hline 30 & i & $106-108$ & 13 & 253.57 & 9.1 & 0.5 & - & 90.4 & - & - & - & - & 15.4 & 82.5 & 0.3 & 1.7 & - \\
\hline 34 & 3 & $70-72$ & 14 & 294.21 & 7.7 & - & - & 92.3 & - & - & - & - & 26.4 & 68.7 & \multicolumn{2}{|r|}{$4.8 \cdots$} & - \\
\hline 38 & 1 & $31-33$ & is & 328.82 & 7.9 & 1.1 & - & 91.0 & - & - & - & - & 2.9 & 87.0 & 1.4 & 8.7 & - \\
\hline 43 & 3 & $45-46$ & 16 & 379.45 & 5.3 & 0.5 & - & 94.2 & - & - & - & - & 6 & 83.7 & 5.2 & 5.1 & - \\
\hline 48 & 3 & $50-52$ & 17 & 427.01 & 10.3 & 7.6 & - & 82.1 & - & - & - & - & 11.1 & 77.8 & \multicolumn{2}{|c|}{11.1} & - \\
\hline so & 1 & $36-38$ & 18 & 433,37 & 8.5 & 5.6 & - & 85.9 & - & - & - & - & 18.1 & 75.1 & 6.7 & - & - \\
\hline 55 & i & $100-101$ & 19 & 481.50 & 9.7 & 8.2 & - & 82.1 & - & - & - & - & 7.7 & 92.3 & - & - & - \\
\hline 57 & $i$ & $81-82$ & 20 & 500.21 & 13.6 & 8.2 & - & 78.2 & - & - & - & - & 100 & - & - & - & - \\
\hline 58 & 3 & $7-8$ & 21 & 512.07 & 17.8 & 10.4 & - & 71.8 & - & - & - & - & 58.3 & 41.7 & - & - & - \\
\hline 61 & 1 & $107-108$ & 22 & 536.57 & 16.8 & 7.8 & - & 65.4 & - & - & - & - & 100 & - & - & - & - \\
\hline 62 & 2 & $15-20$ & 23 & 539.17 & 24.1 & 9.1 & 4.0 & 62.8 & - & - & - & - & 100 & - & - & - & - \\
\hline 66 & 2 & $84-86$ & 24 & 577.85 & 9.4 & 8.5 & - & 82.1 & - & - & - & - & 35.3 & 64.7 & - & - & - \\
\hline 67 & 2 & $108-109$ & 25 & 587.58 & 19.1 & 36.0 & - & 44.9 & - & - & - & - & 10 & 87.8 & 2.2 & - & - \\
\hline 69 & 1 & $145-146$ & 26 & 605.45 & 92.4 & - & 3.0 & - & - & 4.6 & - & - & 100 & - & - & - & - \\
\hline 70 & i & $96-97$ & 27 & 614.46 & 68.0 & 15.6 & - & 3.8 & 8 & 1 & 4 & - & 33.4 & 66.6 & - & - & - \\
\hline 70 & 6 & $40-41$ & 28 & 621.40 & 56.0 & 22.2 & - & 3.8 & 11 & 7 & - & - & - & - & - & - & - \\
\hline 70 & 7 & $25-26$ & 29 & 622.75 & 57,0 & 3.9 & - & 32.0 & - & - & 7 & - & 100 & - & - & - & - \\
\hline 71 & 3 & $100-121$ & 30 & 627.20 & 52.8 & 5.2 & -1 & 41.0 & - & - & - & - & 83.5 & 16.5 & - & - & - \\
\hline 82 & $\mathrm{CC}$ & $0-1$ & 31 & 727.30 & 19.0 & 34.1 & - & 26.9 & - & - & - & - & 100 & - & - & - & - \\
\hline 84 & 2 & $46-47$ & 32 & 738.96 & 6.6 & 12.6 & - & 80.8 & - & - & - & - & - & - & - & - & - \\
\hline
\end{tabular}


APPENDIX C

Bulk Mineralogy and Clay Mineralogy, Site 463 (see Nagel and Schumann, this volume)

\begin{tabular}{|c|c|c|c|c|c|c|c|c|c|c|c|c|c|c|c|c|c|c|c|}
\hline \multirow[b]{3}{*}{ Sample } & \multirow{3}{*}{ 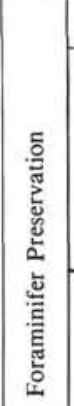 } & \multicolumn{17}{|c|}{ Coarse-Fraction Components } & \multirow{3}{*}{ 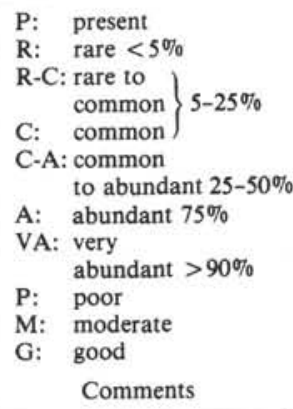 } \\
\hline & & \multicolumn{2}{|c|}{ 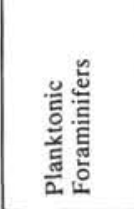 } & \multirow{2}{*}{ 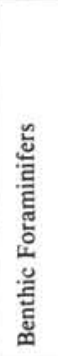 } & \multirow{2}{*}{ 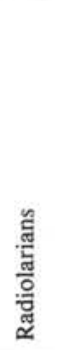 } & \multirow{2}{*}{ 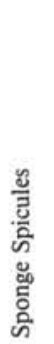 } & \multirow{2}{*}{ 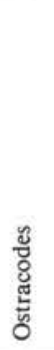 } & \multirow{2}{*}{ 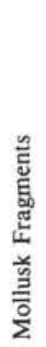 } & \multirow{2}{*}{ 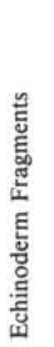 } & \multirow{2}{*}{ 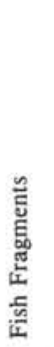 } & \multirow{2}{*}{ 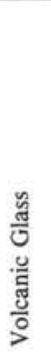 } & \multirow{2}{*}{ 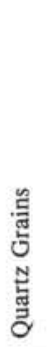 } & \multirow[b]{2}{*}{$\frac{\mathscr{g}}{\Sigma}$} & \multirow[b]{2}{*}{ 苋 } & \multirow{2}{*}{ 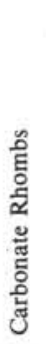 } & \multirow{2}{*}{ 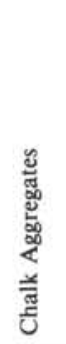 } & \multirow{2}{*}{ 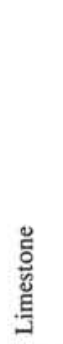 } & \multirow{2}{*}{ 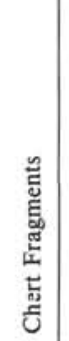 } & \\
\hline & & $\frac{2}{\vdots}$ & 壱 & & & & & & & & & & & & & & & & \\
\hline $\begin{array}{l}1-1,7-9 \mathrm{~cm} \\
1, \mathrm{CC} \\
2, \mathrm{CC} \\
3, \mathrm{CC} \\
4, \mathrm{CC}\end{array}$ & $\begin{array}{l}\mathrm{M} \\
\mathrm{M} \\
\mathrm{P} \\
\mathrm{P} \\
\mathrm{M}\end{array}$ & $\begin{array}{c}\text { A } \\
\text { C-A } \\
\text { C } \\
\text { C } \\
\text { A }\end{array}$ & $\begin{array}{c}\mathrm{C} \\
\mathrm{C}-\mathrm{A} \\
\mathrm{A} \\
\mathrm{A} \\
\mathrm{R}-\mathrm{C}\end{array}$ & $\begin{array}{l}\mathrm{R} \\
\mathrm{R} \\
\mathrm{R} \\
\mathrm{R} \\
\mathrm{R}\end{array}$ & & $\mathbf{P}$ & $\mathbf{R}$ & P & $\mathrm{P}$ & $\begin{array}{l}P \\
P\end{array}$ & & & & & & & & & \\
\hline $\begin{array}{l}5, \mathrm{CC} \\
6, \mathrm{CC} \\
7, \mathrm{CC} \\
8, \mathrm{CC} \\
9, \mathrm{CC}\end{array}$ & \begin{tabular}{|c|}
$\mathrm{P}$ \\
$\mathrm{G}$ \\
$\mathrm{M}$ \\
$\mathrm{M}-\mathrm{G}$ \\
$\mathrm{M}$
\end{tabular} & $\begin{array}{l}\text { C-A } \\
\text { A } \\
\text { VA } \\
\text { VA } \\
\text { VA }\end{array}$ & \begin{tabular}{|c|}
$\mathrm{C}-\mathrm{A}$ \\
$\mathrm{R}$ \\
$\mathrm{R}$ \\
$\mathrm{R}$ \\
$\mathrm{R}-\mathrm{C}$
\end{tabular} & $\begin{array}{l}\mathrm{R} \\
\mathrm{R} \\
\mathrm{R} \\
\mathrm{R} \\
\mathrm{R}\end{array}$ & $P$ & $\mathrm{P}$ & $\mathbf{R}$ & & $\begin{array}{l}\mathrm{R} \\
\mathrm{P}\end{array}$ & $\mathrm{R}$ & & & & & & & & & \\
\hline $\begin{array}{l}10, \mathrm{CC} \\
11, \mathrm{CC} \\
12, \mathrm{CC} \\
13, \mathrm{CC} \\
14, \mathrm{CC}\end{array}$ & $\begin{array}{l}\mathrm{M} \\
\mathrm{M} \\
\mathrm{M} \\
\mathrm{M} \\
\mathrm{G}\end{array}$ & $\begin{array}{l}\text { VA } \\
\text { VA } \\
\text { A } \\
\text { VA } \\
\text { VA }\end{array}$ & $\begin{array}{l}\text { R-C } \\
\text { R-C } \\
\text { R-C } \\
\text { R-C } \\
\text { R-C }\end{array}$ & $\begin{array}{l}\mathrm{R} \\
\mathrm{R} \\
\mathrm{R} \\
\mathrm{R} \\
\mathrm{R}\end{array}$ & & $\mathrm{P}$ & & & $P$ & & & $\mathrm{R}$ & & & & & & $\begin{array}{l}\mathbf{R} \\
\mathrm{R} \\
\mathrm{R} \\
\mathrm{R}\end{array}$ & \\
\hline $\begin{array}{l}15, \mathrm{CC} \\
16, \mathrm{CC} \\
17, \mathrm{CC} \\
18, \mathrm{CC} \\
19, \mathrm{CC}\end{array}$ & $\begin{array}{l}\text { G } \\
G \\
G\end{array}$ & $\begin{array}{l}\text { VA } \\
\text { VA } \\
\text { VA }\end{array}$ & $\begin{array}{l}\text { R-C } \\
\text { R-C } \\
\text { R-C }\end{array}$ & $\begin{array}{l}\mathrm{R} \\
\mathrm{R} \\
\mathrm{R}\end{array}$ & & & & & & & & & & & & & & $\begin{array}{l}\mathbf{R} \\
\mathbf{R}\end{array}$ & \\
\hline $\begin{array}{l}20, \mathrm{CC} \\
21, \mathrm{CC} \\
22, \mathrm{CC} \\
23, \mathrm{CC} \\
24, \mathrm{CC}\end{array}$ & $\begin{array}{l}G \\
G \\
G \\
G\end{array}$ & $\begin{array}{l}\text { A } \\
\text { A } \\
\text { A } \\
\text { A }\end{array}$ & $\begin{array}{l}\mathrm{C} \\
\mathrm{C} \\
\mathrm{C} \\
\mathrm{C}\end{array}$ & $\begin{array}{l}\mathrm{R} \\
\mathrm{R} \\
\mathrm{R} \\
\mathrm{R}\end{array}$ & & $\mathrm{P}$ & 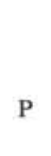 & $\mathbf{P}$ & & & & & & & & & & $\begin{array}{l}\mathrm{R} \\
\mathrm{R} \\
\mathrm{R}\end{array}$ & Lot of small sized \\
\hline $\begin{array}{l}25, \mathrm{CC} \\
26, \mathrm{CC} \\
27, \mathrm{CC} \\
30, \mathrm{CC} \\
31, \mathrm{CC}\end{array}$ & $\begin{array}{c}G \\
G \\
G \\
G \\
P-M\end{array}$ & $\begin{array}{l}\text { A } \\
\text { A } \\
\text { A } \\
\text { A }\end{array}$ & $\begin{array}{l}\mathrm{C} \\
\mathrm{C} \\
\mathrm{C}\end{array}$ & $\begin{array}{l}\mathrm{R} \\
\mathrm{R} \\
\mathrm{R}\end{array}$ & $\mathbf{R}$ & & & & & & & & & & & $\mathbf{R}$ & VA & $\begin{array}{c}\mathrm{R} \\
\mathrm{R} \\
\mathrm{R} \\
\mathrm{R}-\mathrm{C}\end{array}$ & \\
\hline $\begin{array}{l}33, \mathrm{CC} \\
34, \mathrm{CC} \\
35, \mathrm{CC} \\
37, \mathrm{CC} \\
38, \mathrm{CC}\end{array}$ & $\begin{array}{l}\mathrm{M} \\
\mathrm{M} \\
\mathrm{M} \\
\mathrm{P} \\
\mathrm{P}\end{array}$ & $\begin{array}{l}\text { VA } \\
\text { VA } \\
\text { VA } \\
\text { VA } \\
\text { VA }\end{array}$ & $\begin{array}{l}\mathrm{C} \\
\mathrm{C} \\
\mathrm{C} \\
\mathrm{C} \\
\mathrm{C}\end{array}$ & $\begin{array}{l}\mathrm{R} \\
\mathrm{R} \\
\mathrm{R} \\
\mathrm{R} \\
\mathrm{R}\end{array}$ & & & & & $\mathrm{P}$ & & & & & $\mathbf{P}$ & & $\begin{array}{l}R \\
R \\
R \\
R \\
R\end{array}$ & & $\begin{array}{l}\mathrm{P} \\
\mathrm{R} \\
\mathrm{R} \\
\mathrm{R}\end{array}$ & $\begin{array}{l}\text { very small } \\
\text { coarse fraction }\end{array}$ \\
\hline $\begin{array}{l}39, \mathrm{CC} \\
40, \mathrm{CC} \\
41, \mathrm{CC} \\
42, \mathrm{CC} \\
43, \mathrm{CC}\end{array}$ & $\begin{array}{c}\mathrm{M} \\
\mathrm{P}-\mathrm{M} \\
\mathrm{P} \\
\mathrm{P}-\mathrm{M} \\
\mathrm{M}\end{array}$ & $\begin{array}{l}\text { A } \\
\text { C } \\
\text { C } \\
\text { C } \\
\text { C }\end{array}$ & $\begin{array}{l}\mathrm{C} \\
\mathrm{R} \\
\mathrm{R} \\
\mathrm{R} \\
\mathrm{R}\end{array}$ & $\begin{array}{l}\mathrm{R} \\
\mathrm{R} \\
\mathrm{R} \\
\mathrm{R} \\
\mathrm{R}\end{array}$ & $\mathbf{R}$ & & & & & & & & & & & $\begin{array}{l}\text { R-C } \\
\text { C } \\
\text { C } \\
\text { A } \\
\text { C }\end{array}$ & & $\begin{array}{c}P \\
R-C \\
R \\
R \\
R\end{array}$ & $\begin{array}{l}\text { very small } \\
\text { coarse fract. }\end{array}$ \\
\hline $\begin{array}{l}44, C C \\
46, C C \\
48, C C \\
49, C C \\
50, C C\end{array}$ & $\begin{array}{l}\mathrm{M} \\
\mathrm{M} \\
\mathrm{M} \\
\mathrm{M} \\
\mathrm{M}\end{array}$ & $\begin{array}{l}\mathrm{C} \\
\mathrm{C} \\
\mathrm{A} \\
\mathrm{A} \\
\mathrm{C}\end{array}$ & $\begin{array}{l}\mathrm{R} \\
\mathrm{R} \\
\mathrm{R} \\
\mathrm{R} \\
\mathrm{R}\end{array}$ & $\begin{array}{l}\mathrm{R} \\
\mathrm{R} \\
\mathrm{R} \\
\mathrm{R} \\
\mathrm{R}\end{array}$ & $\begin{array}{l}\mathrm{A} \\
\mathrm{P} \\
\mathrm{C}\end{array}$ & $\mathbf{P}$ & $P$ & & & & & & & $P$ & & $\begin{array}{l}\mathbf{R} \\
\mathrm{C} \\
\mathrm{C} \\
\mathrm{R} \\
\mathrm{R}\end{array}$ & & $\begin{array}{l}\mathrm{A} \\
\mathrm{C}\end{array}$ & $\begin{array}{l}\text { very small } \\
\text { coarse fraction }\end{array}$ \\
\hline $\begin{array}{l}52, \mathrm{CC} \\
53, \mathrm{CC} \\
54, \mathrm{CC} \\
55, \mathrm{CC} \\
56, \mathrm{CC}\end{array}$ & $\begin{array}{c}\mathrm{M} \\
\mathrm{P} \\
\mathrm{P} \\
\mathrm{VP} \\
\mathrm{P}\end{array}$ & $\begin{array}{c}R-C \\
R \\
R-C \\
R \\
R\end{array}$ & $\begin{array}{l}R \\
R \\
R \\
R\end{array}$ & $\begin{array}{l}\mathrm{R} \\
\mathrm{R} \\
\mathrm{R} \\
\mathrm{R}\end{array}$ & $\begin{array}{l}\mathrm{A} \\
\mathrm{A} \\
\mathrm{A} \\
\mathrm{A}\end{array}$ & & & & & & & & & & & & $\begin{array}{c}\text { R-C } \\
\text { R-C } \\
\text { R-C } \\
\text { VA } \\
\text { R }\end{array}$ & R-C & \\
\hline $\begin{array}{l}57, \mathrm{CC} \\
58, \mathrm{CC} \\
59, \mathrm{CC} \\
63, \mathrm{CC} \\
64, \mathrm{CC}\end{array}$ & $\begin{array}{l}\mathrm{P} \\
\mathrm{P} \\
\mathrm{P}\end{array}$ & $\begin{array}{l}\mathrm{R} \\
\mathrm{R} \\
\mathrm{R}\end{array}$ & & $\mathrm{R}$ & $\begin{array}{c}\text { R-C } \\
\text { A }\end{array}$ & & & & & & & & & & & & $\begin{array}{l}\text { VA } \\
\text { VA } \\
\text { VA } \\
\text { VA }\end{array}$ & & \\
\hline $\begin{array}{l}65, \mathrm{CC} \\
66, \mathrm{CC} \\
67, \mathrm{CC} \\
70, \mathrm{CC} \\
75, \mathrm{CC}\end{array}$ & $\begin{array}{l}\mathrm{P} \\
\mathrm{P}\end{array}$ & $\begin{array}{l}\mathrm{P} \\
\mathrm{R}\end{array}$ & & & $\begin{array}{l}\text { A } \\
\text { C }\end{array}$ & $\begin{array}{l}\mathrm{P} \\
\mathrm{R}\end{array}$ & & & P* & $P$ & & & & $\mathbf{R}$ & R & & $\begin{array}{c}\text { VA } \\
\text { VA } \\
\text { C } \\
\text { A } \\
\text { VA }\end{array}$ & $\mathbf{R}$ & "silicified \\
\hline
\end{tabular}


APPENDIX D

Physical-Property Measurements, Site 463 (see Fujii, this volume)

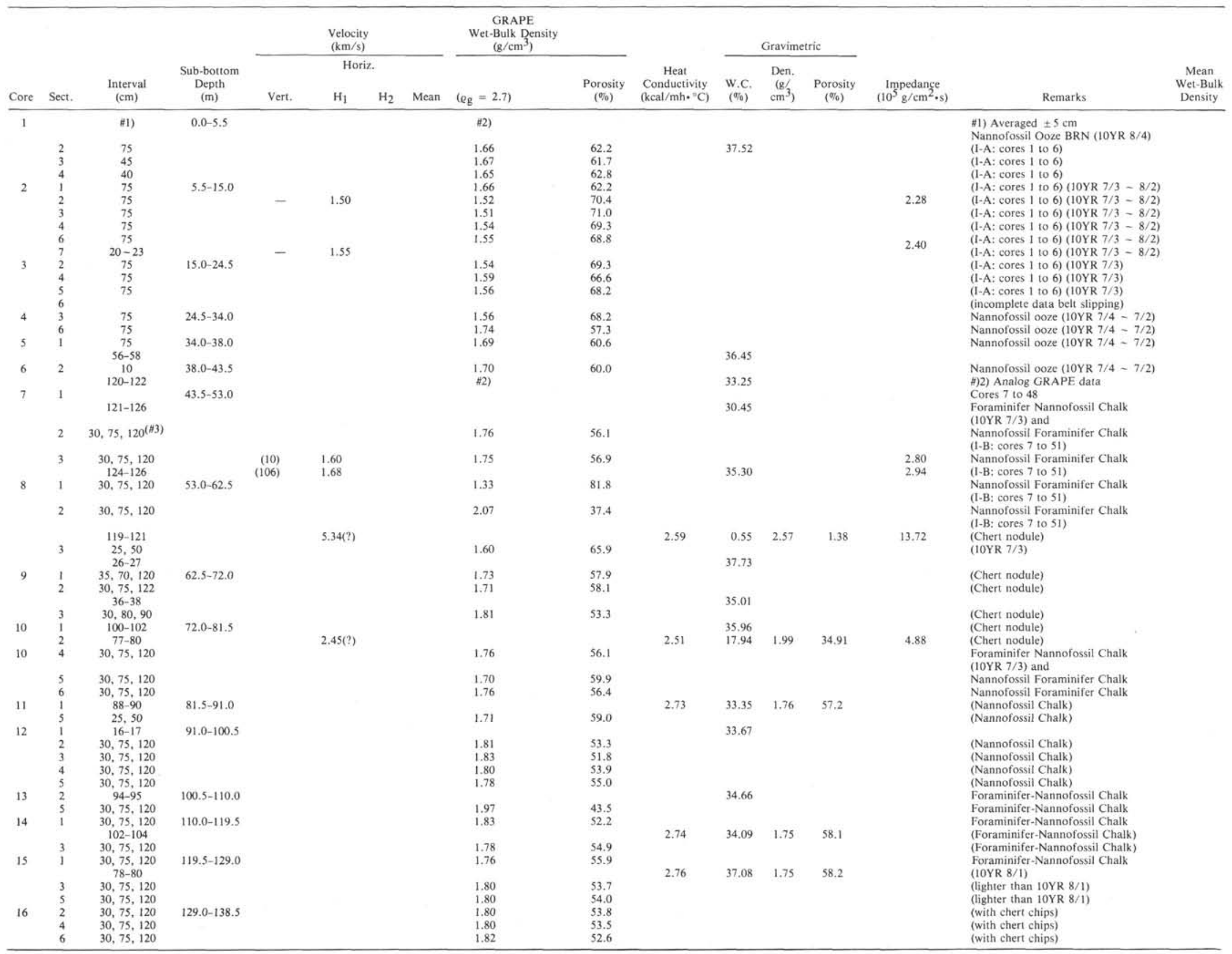




\begin{tabular}{|c|c|c|c|c|c|c|c|c|c|c|c|c|c|c|c|c|}
\hline \multirow[b]{2}{*}{ Core } & \multirow[b]{2}{*}{ Sect. } & \multirow[b]{2}{*}{$\begin{array}{l}\text { Interval } \\
(\mathrm{cm})\end{array}$} & \multirow[b]{2}{*}{$\begin{array}{l}\text { Sub-bottom } \\
\text { Depth } \\
\text { (m) }\end{array}$} & \multicolumn{4}{|c|}{$\begin{array}{l}\text { Velocity } \\
(\mathrm{km} / \mathrm{s})\end{array}$} & \multicolumn{2}{|l|}{$\begin{array}{c}\text { GRAPE } \\
\text { Wet-Bulk Density } \\
\left(\mathrm{g} / \mathrm{cm}^{3}\right)\end{array}$} & \multirow[b]{2}{*}{$\begin{array}{c}\text { Heat } \\
\text { Conductivity } \\
\left(\mathrm{kcal} / \mathrm{mh} \cdot{ }^{\circ} \mathrm{C}\right)\end{array}$} & \multicolumn{3}{|c|}{ Gravimetric } & \multirow[b]{2}{*}{$\begin{array}{l}\text { Impedance } \\
\left(10^{5} \mathrm{~g} / \mathrm{cm}^{2} \cdot \mathrm{s}\right)\end{array}$} & \multirow[b]{2}{*}{ Remarks } & \multirow[b]{2}{*}{$\begin{array}{c}\text { Mean } \\
\text { Wet-Bulk } \\
\text { Density }\end{array}$} \\
\hline & & & & Vert. & $\mathrm{H}_{1}$ & $\mathrm{H}_{2}$ & Mean & $\left(e_{g}=2.7\right)$ & $\begin{array}{l}\text { Porosity } \\
(\%)\end{array}$ & & $\begin{array}{l}\text { W.C. } \\
(\%)\end{array}$ & $\begin{array}{l}\text { Den. } \\
(\mathrm{g} / \\
\left.\mathrm{cm}^{3}\right)\end{array}$ & $\begin{array}{l}\text { Porosity } \\
(\%)\end{array}$ & & & \\
\hline \multirow[t]{3}{*}{17} & 1 & $45-47$ & $138.5-148.0$ & & $5.23(?)$ & & & & & & & & & & Chert nodule & \\
\hline & $\begin{array}{l}2 \\
4\end{array}$ & $\begin{array}{l}30,75,120 \\
30,75,120\end{array}$ & & & & & & 1.87 & 49.5 & & & & & & Foraminifer-Nannofossil Chalk & \\
\hline & 6 & $30,75,120$ & & & & & & $\begin{array}{l}1.82 \\
1.87\end{array}$ & $\begin{array}{l}52.8 \\
49.8\end{array}$ & & & & & & (disturbed with chalk pieces) & \\
\hline \multirow[t]{4}{*}{19} & 1 & $60-62$ & $157.5-167.0$ & & & & & & & & 24.95 & & & & $\begin{array}{l}\text { Foraminter-Nannotossil Ooze } \\
\text { Foraminifer-Nannofossil Chalk }\end{array}$ & \\
\hline & 2 & $30,75,120$ & 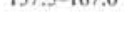 & & & & & 1.82 & 52.7 & & & & & & Foraminifer-Nannofossil Chalk & \\
\hline & 4 & $30,75,120$ & & & & & & 1.84 & 51.6 & & & & & & Foraminifer-Nannofossil Chalk & \\
\hline & 6 & $30,75,120$ & & & & & & 1.80 & 53.8 & & & & & & $\begin{array}{l}\text { (with chert chips) } \\
\text { (1) the }\end{array}$ & \\
\hline \multirow[t]{2}{*}{20} & $i$ & $70,90,110$ & $167.0-176.5$ & & & & & 2.02 & 40.6 & & & & & & (with chert chips) & \\
\hline & & $80-82$ & & & & & & & & & 31.60 & & & & (with chert chips) & \\
\hline \multirow[t]{3}{*}{21} & 1 & $53-55$ & $176.5-186.0$ & & & & & 1.84 & 5.4 & & 30.69 & & & & (with chert chips) & \\
\hline & $\frac{2}{4}$ & $\begin{array}{l}30,75,120 \\
30,75,120\end{array}$ & & & & & & $\begin{array}{l}1.84 \\
1.84\end{array}$ & $\begin{array}{l}51.4 \\
51.3\end{array}$ & & & & & & $\begin{array}{l}\text { (chert chips) } \\
\text { (chert chips) }\end{array}$ & \\
\hline & 6 & $30,75,120$ & & & & & & 1.90 & 41.5 & & & & & & (chert chips) & \\
\hline \multirow[t]{3}{*}{22} & $i$ & $55-51$ & $186.0-195.5$ & & & & & & & & 30.48 & & & & Foraminifer-Nannofossil & \\
\hline & 2 & $30,75,120$ & & & & & & 1.87 & 49.8 & & & & & & (chalk and chert) & \\
\hline & 4 & $30,75,110$ & & & & & & 1.85 & 51.0 & & & & & & (Ooze and chalk) & \\
\hline 23 & $i$ & 35,80, iis & $195.5-199.5$ & & & & & 1.82 & 52.4 & & & & & & (Ooze and chalk) & \\
\hline 24 & $i$ & $30,75,120$ & $199.5-205.0$ & & & & & 1.92 & 46.8 & & & & & & (Ooze and chalk) & \\
\hline & 3 & $\begin{array}{l}66-68 \\
40,80\end{array}$ & & & & & & 1.88 & 48.7 & & 26.02 & & & & (Ooze and chalk) & \\
\hline 25 & 2 & 40,80 & $205.0-214.5$ & & & & & 1.81 & 53.0 & & & & & & $\begin{array}{l}\text { (Ooze and chalk) } \\
\text { Foraminifer-Nannofossil Chalk }\end{array}$ & \\
\hline 26 & $i$ & $58-61$ & $214.5-224.0$ & (1.69) & 1.69 & & & (1.85) & & & & & & 3.13 & Foraminifer-Nannofossil Chalk & \\
\hline & 3 & $\begin{array}{c}110-112 \\
30,75,120\end{array}$ & & & & & & 1.85 & 51.0 & & 34,20 & & & & (some chert frag,) & \\
\hline & 6 & $30,75,120$ & & & & & & 1.85 & 51.0 & & & & & & $\begin{array}{l}\text { (some chert Irag.) } \\
\text { (firm and soupy) }\end{array}$ & \\
\hline & 5 & $46-48$ & & 1.71 & 1.74 & & 1.73 & & & 2.74 & 33.32 & 1.76 & 57.2 & 3.06 & $\begin{array}{l}\text { Foraminifer-Nannofossil Chalk } \\
\text { (Firm) (Minicore) }\end{array}$ & \\
\hline & 5 & $50-52$ & & 1.72 & 1.73 & & 1.73 & & & & & & & & $\begin{array}{l}\text { Foraminifer-Nannofossil Chalk } \\
\text { (Firm) (split core) }\end{array}$ & \\
\hline 27 & 1 & $50,90,130$ & $224.0-233.5$ & & & & & 1.80 & 54.1 & & & & & & $\begin{array}{l}\text { Foraminifer-Nannofossil Chalk } \\
\text { (Firm) (Pink 7.5YR 8/4) }\end{array}$ & \\
\hline & & $108-109$ & & & & & & & & & 33.13 & & & & & \\
\hline & & $140-142$ & & 1.91 & 1.78 & & 1.85 & & & 2.74 & 32.18 & 1.78 & 55.9 & 3.40 & & \\
\hline 29 & $\begin{array}{c}\mathrm{CC} \\
1\end{array}$ & $\overline{40}$ & $243.0-252.5$ & & $5.30(?)$ & & & 1.86 & 50.5 & & & & & & Chert nodule & \\
\hline & & $34-36$ & & 1.79 & 1.81 & & 1.80 & (1.84) & & & & & & 3.29 & $\begin{array}{l}\text { (5YR } 7 / 1) \\
\text { (firm Chalk) }\end{array}$ & \\
\hline 30 & 1 & $\begin{array}{c}52-54 \\
30,75,120\end{array}$ & & & & & & & & 2.75 & 30.17 & 1.82 & 53.7 & & (firm Chalk) & \\
\hline & & $\begin{array}{c}30,75,120 \\
130-132\end{array}$ & $252.5-262.0$ & & & & & 1.94 & 45.6 & & 23.79 & & & & Limestone and Chalk & \\
\hline & 2 & $30,75,120$ & & & & & & 1.93 & 46.1 & & & & & & Nannofossil Chalk and Limestone & \\
\hline & $C C$ & $87-89$ & & 2.14 & 2.21 & & 2.18 & & & 2,70 & 22.61 & 1.97 & 43.5 & 4.22 & Chalk (light grey green) & \\
\hline 31 & 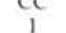 & $\overline{4-6}$ & $2620-2715$ & 2.51 & $2,60(?)$ & & & & & 2.48 & 17.50 & 1.99 & 33.9 & 4.99 & Limestone (white) & \\
\hline 33 & 1 & $30,75,120$ & $\begin{array}{l}262.0-271.5 \\
281.0-290.5\end{array}$ & & & & & 2.00 & 415 & 2.75 & 26.72 & 1.90 & 49.5 & & & \\
\hline & & $\begin{array}{l}107-109 \\
109\end{array}$ & & & & & & & & & 29.73 & & & & & \\
\hline 33 & 2 & $\begin{array}{l}137-139 \\
30,75,120\end{array}$ & & 2.06 & $2.17(?)$ & & 2.12 & $\begin{array}{c}(2.00) \\
1.81\end{array}$ & 530 & & & & & 4.12 & (firm Chalk) & \\
\hline 34 & $i$ & $108-110$ & $290.5-300.0$ & & & & & 1.81 & 53.0 & & 29.37 & & & & & \\
\hline & 2 & $\begin{array}{l}70-72 \\
75\end{array}$ & & 1.91 & 2.00 & & 1.96 & $(1.81)$ & & & & & & 3.46 & Foraminifer-Nannofossil Chalk & \\
\hline & 2 & $142-144$ & & 2.10 & 2.02 & & 2.06 & $\begin{array}{c}1.90 \\
(1.90)\end{array}$ & 47.8 & & & & & 3.99 & Foraminifer-Nannofossil Chalk & \\
\hline 35 & 3 & 35,65 & & & & & & 1.82 & 52.3 & & & & . & & (grey stripe Vel to $H$ ) & \\
\hline $\begin{array}{l}35 \\
38\end{array}$ & $\mathrm{cc}$ & $17-18$ & $300.0-309.5$ & & & & & & & 2.68 & 30.26 & 1.80 & 53.2 & & & \\
\hline $\begin{array}{l}38 \\
43\end{array}$ & 1 & $\begin{array}{l}40-42 \\
70\end{array}$ & $\begin{array}{l}328.5-338.0 \\
376.0-385.5\end{array}$ & & & & & 1.93 & 460 & 2.69 & 26.08 & 1.89 & 48.1 & & & \\
\hline & 3 & $20,50,80$ & & & & & & 1.95 & 44.6 & & & & & & & \\
\hline & 5 & 25,50 & & & & & & 1.75 & 57.0 & & & & & & & \\
\hline 48 & 1 & $\begin{array}{l}119-121 \\
30-75,120\end{array}$ & $423.5-427.5$ & & & & & 1.96 & 441 & & 23.85 & & & & & \\
\hline & $\begin{array}{l}2 \\
3\end{array}$ & $\begin{array}{l}30,75,120 \\
25,60,85\end{array}$ & & & & & & 2.05 & 39.1 & & & & & & & \\
\hline 53 & c & $121-123$ & $460.5-471.0$ & $\begin{array}{l}2.365 \\
5.77(?)\end{array}$ & $\begin{array}{l}2.32 \\
5.59\end{array}$ & $\begin{array}{c}2.37 \\
-\end{array}$ & $\begin{array}{l}2.35 \\
5.68\end{array}$ & $\begin{array}{l}2.15 \\
2.64\end{array}$ & $\begin{array}{r}32.65 \\
0.37\end{array}$ & $\begin{array}{l}2.70 \\
2.67\end{array}$ & $\begin{array}{l}17.01 \\
1.56\end{array}$ & $\begin{array}{l}2.11 \\
2.60\end{array}$ & $\begin{array}{r}35.07 \\
4.02\end{array}$ & $\begin{array}{r}5.04 \\
15.12\end{array}$ & Green Limestone & $\begin{array}{l}(2.13) \\
(2.62)\end{array}$ \\
\hline
\end{tabular}


Appendix D. Continued.

\begin{tabular}{|c|c|c|c|c|c|c|c|c|c|c|c|c|c|c|c|c|}
\hline \multirow[b]{3}{*}{ Core } & \multirow[b]{3}{*}{ Sect. } & \multirow{3}{*}{$\begin{array}{c}\text { Interval } \\
(\mathrm{cm})\end{array}$} & \multirow{3}{*}{$\begin{array}{l}\text { Sub-bottom } \\
\text { Depth } \\
(\mathrm{m})\end{array}$} & \multicolumn{4}{|c|}{$\begin{array}{l}\text { Velocity } \\
(\mathrm{km} / \mathrm{s})\end{array}$} & \multicolumn{2}{|c|}{$\begin{array}{c}\text { GRAPE } \\
\text { Wet-Bulk Density } \\
\left(\mathrm{g} / \mathrm{cm}^{3}\right) \\
\end{array}$} & \multirow{3}{*}{$\begin{array}{c}\text { Heat } \\
\text { Conductivity } \\
\left(\mathrm{kcal} / \mathrm{mh} \cdot{ }^{\circ} \mathrm{C}\right)\end{array}$} & \multicolumn{3}{|c|}{ Gravimetric } & \multirow{3}{*}{$\begin{array}{l}\text { Impedance } \\
\left(10^{5} \mathrm{~g} / \mathrm{cm}^{2} \cdot \mathrm{s}\right)\end{array}$} & \multirow[b]{3}{*}{ Remarks } & \\
\hline & & & & & & & & & & & & Den. & & & & \\
\hline & & & & vert. & $\mathrm{H}_{1}$ & $\mathrm{H}_{2}$ & Mean & $\left(\varrho_{g}=2.7\right)$ & $\begin{array}{l}\text { Porosity } \\
(\%)\end{array}$ & & $\begin{array}{l}\text { W.C. } \\
(\%)\end{array}$ & $\begin{array}{l}(\mathrm{g} / 3 \\
\left.\mathrm{cm}^{3}\right)\end{array}$ & $\begin{array}{l}\text { Porosity } \\
(\%)\end{array}$ & & & $\begin{array}{c}\text { Wet-Bulk } \\
\text { Density }\end{array}$ \\
\hline 54 & $\mathrm{cC}$ & & $471-480.5$ & $2.54(?)$ & 2.55 & 2.53 & 2.54 & 2.11 & 35.24 & 2.73 & 18.69 & 2.08 & 37.96 & 5.32 & Limestone (white) & $(2,10)$ \\
\hline & & & & $5.520 \%$ & 5.61 & & 5.57 & 2.60 & 2.86 & 2.67 & 1.94 & 2.59 & 4.89 & 14.32 & Chert (pale brown) & $(2.60)$ \\
\hline 55 & 1 & $19-21$ & $480,5-490$ & 2.40 & 2.42 & 2.43 & 2.42 & 2.17 & 31.55 & 2.70 & 15.23 & 2.16 & 32.16 & 5.20 & Limestone (Green) & $(2.17)$ \\
\hline & & $79-81$ & & $\left.4933^{\circ}\right)$ & 53 & - & 315 & 245 & 1205 & 261 & 2.97 & 2.50 & 7.23 & 12.20 & Chert (Gray) & $(2.48)$ \\
\hline 56 & 1 & 93-95 & $490-499.5$ & & 2.56 & & & 2.24 & 27,33 & 2.70 & 14.62 & 2.18 & 31.12 & 5.66 & Limestone (Gray) & $(2,21)$ \\
\hline 57 & 1 & $86-88$ & $499-5-509$ & 3.56 & 3.70 & 3.73 & 3.66 & 2.48 & 13.12 & 2.73 & 7.91 & 2.41 & 18.60 & 8.70 & Limestone (brown) & $(2.46)$ \\
\hline & 2 & $2-4$ & & 2.53 & 2.56 & 2.60 & 2.56 & 2.14 & 33.59 & 2.69 & 15.88 & 2.14 & 33.10 & 5.41 & Limestone (Gray) & $(2,14)$ \\
\hline 58 & 1 & $40-42$ & $509.0-518.5$ & 3.66 & 3.77 & 3.81 & 3.75 & 2.45 & 15.08 & 2.72 & 8.19 & 2.40 & 19.17 & 8.88 & Limestone (pale-brown) & $(2.43)$ \\
\hline & 2 & $53-55$ & & 3.41 & 3.44 & 3.59 & 3.48 & 2.39 & 18.70 & 2.73 & 9.85 & 2.35 & 22.57 & 8.08 & Limestone (light Gray) & $(2.37)$ \\
\hline & 3 & $29-31$ & & 309 & 3.42 & 3.44 & 3.32 & 239 & 18.74 & 274 & 877 & 239 & 2048 & 739 & imetone (Gireen and plate brown) & 2,390 \\
\hline & $\mathrm{CC}$ & (5) & & 3.77 & 3.97 & 3.95 & 3.90 & 2.51 & 11.63 & 2.72 & 5.01 & 251 & 12.27 & 9.46 & $\begin{array}{l}\text { Limestone (pale brown) } \\
\text { lis }\end{array}$ & $(2.51)$ \\
\hline 59 & & $65-68$ & $5185-528$ & 362 & 375 & & & 241 & 17.47 & 273 & 877 & 2,30 & 02040 & 869 & (ifectone (White) & 0400 \\
\hline & 3 & $\begin{array}{l}89-00 \\
89-91\end{array}$ & $0.0 .0-0.0$ & 3.08 & 3.33 & & & 2.36 & 20.05 & 2.72 & 8.51 & 2.39 & 19.82 & 0.032 & Limestone (pale brown) & $(2.38)$ \\
\hline 60 & 2 & $61-63$ & $528-535.5$ & 3.25 & 3.40 & & & 2.32 & 22.80 & 2.70 & 10.69 & 2,30 & 24.00 & 7.51 & Limestone (pale brown) & (2.31) \\
\hline & 4 & $67-69$ & & 2.91 & 3.19 & & & 2.38 & 19.13 & 2.71 & 9.12 & 2.36 & 20.98 & 6.90 & Limestone (dark brown) & (2.37) \\
\hline 61 & & $48-50$ & $535.5-537.5$ & 4.07 & 4.45 & & & 2.53 & 10.16 & 2.69 & 6.16 & 2.45 & 14,73 & 10.13 & Limestone (brown) & (2.49) \\
\hline 62 & 1 & $15-17$ & $537.5-547$ & 2.64 & 2.85 & & & 2.33 & 21.95 & 2.65 & 11.11 & 2.26 & 24.46 & 6.08 & Limestone (Grey) '(coarse grain) & (2.30) \\
\hline & 3 & $95-97$ & & 3.23 & 3.48 & & & 2.39 & 18.82 & 2.67 & 4.26 & 2.82 & 21.01 & 7.61 & Limestone (pale brown-Gray) & (2.36) \\
\hline 63 & 1 & $9-11$ & $547-556.5$ & 3.37 & 3,61 & 3.51 & 3.50 & 2.35 & 21.03 & 2.67 & 10.06 & 2.30 & 22.58 & 7.84 & Limestone (pale brown and Pink) & $(2.33)$ \\
\hline & 2 & $117-119$ & & 3.28 & 3.51 & 3,42 & 3.40 & 2.34 & 21.58 & 2.70 & 11.39 & 2.27 & 25.29 & 7.56 & Limestone (white) & (2.31) \\
\hline 64 & 1 & $35-37$ & $556.5-566$ & 2.98 & 3.23 & 3.25 & 3.15 & 2.26 & 26.35 & 2.71 & 14.20 & 2.20 & 30.48 & 6.65 & Limestone (white) & (2.23) \\
\hline & 2 & $110-112$ & & 3.31 & 3.44 & 3.42 & 3.39 & 2.40 & 17.78 & 2.74 & 9.82 & 2.35 & 22.53 & 7.86 & Limestone (brown) & (2.38) \\
\hline 65 & 1 & $64-66$ & $566-575.5$ & 3.23 & 3.44 & 3.39 & 3.35 & 2.31 & 23.27 & 2.74 & 11.14 & 2.31 & 25.11 & 7.46 & Limestone (pale brown to pink) & $(2,31)$ \\
\hline & 2 & $40-42$ & & 3.46 & 3.81 & 3.69 & 3.65 & 2.40 & 18.19 & 2.71 & 9.67 & 2,34 & 22.06 & 8.20 & Limestone (pale brown) & (2.37) \\
\hline 66 & i & $57-59$ & $575.5-585$ & 3.06 & 3.35 & 3.30 & 3.24 & 2.32 & 22.81 & 2.71 & 12.12 & 2.26 & 26.74 & 7.01 & Limestone (white to gray) & (2.29) \\
\hline & 2 & $20-21$ & $585-594.5$ & 3.04 & 3.44 & 3.21 & 3.23 & 2.32 & 22.45 & 2.71 & 13.45 & 2.22 & 29.15 & 6.90 & Limestone (Gray) & (2.27) \\
\hline 67 & $i$ & $69-71$ & $585-594.5$ & 3.24 & 3.49 & 3.47 & 3.40 & 2.43 & 16.38 & 2.72 & 9.84 & 2.34 & 22.48 & 7.73 & Limestone (Gray) & (2.39) \\
\hline & 2 & $21-23$ & & 3.12 & 3.33 & 3.36 & 3.29 & 2.34 & 21.65 & 2.71 & 12.04 & 2.26 & 26.60 & 7.18 & Limestone (Gray) & (2.30) \\
\hline 69 & 2 & $25-26$ & $607-613.5$ & 2.15 & 2.62 & & & 2.14 & 33.17 & 2.69 & 15.10 & 2.16 & 31.85 & 5.27 & Limestone & $(2.15)$ \\
\hline & & $98-100$ & & 2.27 & 2.43 & & & 2.20 & 29.65 & 2.73 & 14.26 & 2.21 & 30.71 & 5.01 & Limestone (Gray-Green) & (2.21) \\
\hline 70 & 1 & $59-61$ & $613.5-623$ & 3.42 & 3.58 & & & 2.19 & 30.42 & 2.55 & 11.02 & 2.19 & 23.56 & 7.49 & Limestone (Gray) & (2.19) \\
\hline & 4 & $66-68$ & & 2.53 & 3.00 & & & 2.23 & 28.00 & 2.83 & 18.39 & 2.14 & 38.37 & 5.53 & $\begin{array}{l}\text { Black inclusion } \\
\text { Limestone (Gray) }\end{array}$ & \\
\hline & 5 & $113-115$ & & 2.67 & 2.68 & & & & & 2.39 & 15.40 & 1.98 & 29.84 & 5.29 & $\begin{array}{l}\text { Limestone (Gray) } \\
\text { Limestone (Black) }\end{array}$ & 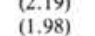 \\
\hline 71 & $i$ & $21-23$ & $623-632.5$ & 2.24 & 2.45 & & & 1.95 & 44.89 & 2.51 & 22.23 & 1.90 & 41.14 & 4.31 & Limestone (Green) & (1.93) \\
\hline 71 & 2 & $121-123$ & $623-632.5$ & 2.93 & 3.38 & 3.36 & 3.22 & 2.34 & 21.64 & 2.70 & 11.77 & 2.26 & 25.99 & 6.34 & Limestone (white) Coarse grain & (2.30) \\
\hline 72 & 2 & $102-104$ & $632.5-642$ & 2.98 & 3.12 & & & 2.09 & 36.47 & $1.79(?)$ & 13.90 & 1.62 & 21.96 & 6.23 & Limestone (Gray) & $(2.09)$ \\
\hline & 3 & $30-32$ & & 2.92 & 3.06 & & & 2.09 & 36.72 & 2.52 & 13.61 & 2.10 & 27.92 & 6.12 & Limestone (Gray) & $(2.10)$ \\
\hline 73 & 1 & $8-10$ & $642-651.5$ & 3.56 & 3.78 & & & 2.40 & 17.91 & 2.65 & 8.00 & 2.35 & 18.35 & 8.46 & Limestone (light Gray) & $(2.38)$ \\
\hline & 2 & $103-105$ & & 3.01 & 3.18 & & & 2.11 & 35.49 & 2.49 & 13.30 & 2.09 & 27.32 & 6.32 & Limestone (Gray) & (2.10) \\
\hline 74 & $i$ & $76-78$ & $651.5-661.0$ & 2.56 & 2.76 & & & 1.99 & 42.72 & 2.47 & 16.75 & 2.00 & 32.69 & 5.11 & Limestone (Green) & $(2.00)$ \\
\hline 76 & $i$ & $41-43$ & $670.5-680$ & 3.40 & 3.55 & & & 2.34 & 21.52 & 2.62 & 10.66 & 2.25 & 23.41 & 11.80 & Limestone (White, black inclusion) & $(2.30)$ \\
\hline & $i$ & $123-125$ & & 2.33 & 2.30 & & & 2.09 & 36.58 & 2.53 & 18.64 & 1.99 & 36.13 & 4.75 & $\begin{array}{l}\text { Limestone (Gray) } \\
\text { (a) }\end{array}$ & $(2.04)$ \\
\hline 77 & $i$ & $30-32$ & $680-689.5$ & 3.16 & 3.29 & & & 2.35 & 20.74 & 2.63 & 9.70 & 2.28 & 21.61 & 7.32 & Limestone (White, black strips) & $(2.32)$ \\
\hline 78 & $i$ & $44-46$ & $689.5-699$ & 3.55 & 3.58 & & & 2.34 & 21.40 & 2.69 & 10.16 & 2.31 & 22.92 & 8.25 & Limestone (White, black strips) & (2.33) \\
\hline 79 & $i$ & $42-44$ & $699-6708.5$ & 4.61 & 4.63 & & & 2.58 & 6.94 & 2.68 & 4.66 & 2.49 & 11.35 & 11.69 & Limestone (White) & (2.54) \\
\hline 80 & $i$ & $36-38$ & $708.5-710.5$ & 3.93 & 4.17 & & & 2.57 & $\begin{array}{l}6.94 \\
7.75\end{array}$ & $\begin{array}{l}2.68 \\
2.72\end{array}$ & 4.24 & 2.54 & 10.50 & 10.04 & (Coral Reef Sed) (Pebbly) & (2.56) \\
\hline 81 & $i$ & $76-78$ & $710.5-718.0$ & 3.97 & 4.05 & & & 2.65 & 3.26 & 2,71 & 3.79 & 2.55 & 9.43 & 10.32 & $\begin{array}{l}\text { (Coral Reef Sed.) } \\
\text { Pebbly Limestone }\end{array}$ & $(2.60)$ \\
\hline 82 & 1 & $31-33$ & $718.0-721.5$ & 3.12 & 3.43 & & & 2.36 & 20.23 & 2.68 & 10.48 & 2.29 & 23.45 & 7.25 & Limestone (Gray) & $(2,33)$ \\
\hline 83 & $i$ & $66-68$ & $721.5-7370$ & 275 & 274 & & & 220 & 2964 & 266 & 14.32 & 216 & 30.26 & 600 & Limestone (White) & $(2,18)$ \\
\hline & 2 & $30-32$ & & 3.80 & 4.19 & & & 2.43 & 15.87 & 2.88 & 7.68 & 2.53 & 18.97 & 9.42 & Limestone (White and Gray Stripe) & $(2.48)$ \\
\hline 84 & $i$ & $28-30$ & $737.0-746.5$ & 4.02 & 4.20 & & & 2.48 & 18.05 & 2.90 & 6.24 & 2.60 & 15.83 & 10.21 & Limestone (Pebbly) & $(2.54)$ \\
\hline 84 & 1 & $114-116$ & $131.0-140.3$ & $\begin{array}{l}4.02 \\
3.46\end{array}$ & 3.67 & & & 2.38 & 19.28 & 2.88 & $\begin{array}{l}8.24 \\
8.66\end{array}$ & 2.49 & 21.06 & 8.43 & Limestone (light Gray) & $(2.44)$ \\
\hline 85 & $\mathrm{i}$ & $43-45$ & $746.5-756.0$ & 3.24 & 3.68 & & & 2.26 & 26.42 & 2.70 & 8.45 & 2.37 & 19.54 & 7.50 & Limestone (Gray) & $(2.32)$ \\
\hline & 2 & $62-64$ & & 4.29 & 4.59 & & & 2.57 & 7.62 & 2.71 & 5.61 & 2.48 & 13.56 & 0.3 & Limestone (Pebbly) & (2.53) \\
\hline 86 & 1 & $6-8$ & $756.0-765.5$ & 4.53 & 4.87 & & & 2.58 & 7.12 & 2.68 & 5.08 & 2.48 & 12.28 & 11.46 & Limestone (White) & (2.53) \\
\hline 88 & $\mathrm{i}$ & $82-84$ & $775.0-784.5$ & 3.93 & 4.20 & & & 2.56 & 8.10 & 2.69 & 6.07 & 2.45 & 14.53 & 9.8 & Limestone (Pebbly) & (2.51) \\
\hline 89 & $i$ & $38-40$ & $784.5-794.0$ & 3.52 & 3.58 & & & 2.45 & 14.70 & 2.72 & 8.48 & 2.39 & 19.75 & 8.52 & Limestone (Gray) & (2.42) \\
\hline & $i$ & $96-98$ & & 3.78 & 3.92 & & & 2.46 & 14.53 & 2.36 & 8.04 & 2.12 & 17.85 & 9.30 & Limestone (Gray, Coarse Grain) & $(2.46)$ \\
\hline
\end{tabular}


APPENDIX E

Grain-Size Analysis, Site 463

\begin{tabular}{|c|c|c|c|c|c|c|c|c|}
\hline Hole & Core & Section & $\begin{array}{l}\text { Interval } \\
(\mathrm{cm})\end{array}$ & $\begin{array}{l}\text { Sub-bottom } \\
\text { Depth } \\
\text { (m) }\end{array}$ & $\begin{array}{c}\text { Sand } \\
(\%)\end{array}$ & $\begin{array}{l}\text { Silt } \\
(\%)\end{array}$ & $\begin{array}{l}\text { Clay } \\
(\%)\end{array}$ & Classification \\
\hline 463 & 1 & 2 & 28.0 & 1.78 & 10.8 & 25.3 & 64.0 & Silty clay \\
\hline 463 & 1 & 4 & 28.0 & 4.78 & 12.5 & 33.7 & 53.8 & Silty clay \\
\hline 463 & 2 & 2 & 60.0 & 7.60 & 8.3 & 25.5 & 66.2 & Silty clay \\
\hline 463 & 2 & 4 & 60.0 & 10.60 & 5.7 & 34.7 & 59.6 & Silty clay \\
\hline 463 & 3 & 2 & 58.0 & 17.08 & 2.4 & 40.1 & 57.5 & Silty clay \\
\hline 463 & 3 & 4 & 58.0 & 20.08 & 2.1 & 35.1 & 62.8 & Silty clay \\
\hline 463 & 4 & 2 & 58.0 & 26.58 & 1.5 & 56.3 & 42.2 & Clayey silt \\
\hline 463 & 4 & 4 & 58.0 & 29.58 & 39.3 & 44.9 & 15.8 & Sandy silt \\
\hline 463 & 5 & 2 & 54.0 & 36.04 & 0.5 & 57.5 & 41.9 & Clayey silt \\
\hline 463 & 6 & 2 & 42.0 & 39.92 & 1.0 & 55.2 & 43.8 & Clayey silt \\
\hline 463 & 6 & 4 & 42.0 & 42.92 & 1.1 & 55.7 & 43.2 & Clayey silt \\
\hline 463 & 7 & 2 & 60.0 & 45.60 & 2.4 & 59.7 & 38.0 & Clayey silt \\
\hline 463 & 7 & 3 & 110.0 & 47.60 & 5.4 & 45.8 & 48.8 & Silty clay \\
\hline 463 & 10 & 3 & 70.0 & 75.70 & 18.1 & 35.7 & 46.2 & Silty clay \\
\hline 463 & 10 & 5 & 70.0 & 78.70 & 12.1 & 45.4 & 42.5 & Clayey silt \\
\hline 463 & 12 & 4 & 40.0 & 95.90 & 12.8 & 39.7 & 47.5 & Silty clay \\
\hline 463 & 13 & 2 & 58.0 & 102.58 & 13.7 & 41.8 & 44.5 & Silty clay \\
\hline 463 & 14 & 4 & 40.0 & 114.90 & 15.1 & 44.3 & 40.6 & Clayey silt \\
\hline 463 & 15 & 2 & 67.0 & 121.67 & 6.7 & 45.5 & 47.8 & Silty clay \\
\hline 463 & 15 & 4 & 67.0 & 124.67 & 7.1 & 43.3 & 49.6 & Silty clay \\
\hline 463 & 16 & 2 & 54.0 & 131.04 & 3.9 & 48.9 & 47.2 & Clayey silt \\
\hline 463 & 16 & 6 & 54.0 & 137.04 & 13.8 & 44.7 & 41.5 & Clayey silt \\
\hline 463 & 17 & 2 & 103.0 & 141.03 & 27.8 & 30.9 & 41.2 & Sand-silt-clay \\
\hline 463 & 17 & 4 & 103.0 & 144.03 & 7.8 & 39.0 & 53.2 & Silty clay \\
\hline 463 & 19 & 2 & 118.0 & 160.18 & 6.1 & 46.3 & 47.6 & Silty clay \\
\hline 463 & 19 & 4 & 60.0 & 162.60 & 7.4 & 45.9 & 46.7 & Silty clay \\
\hline 463 & 20 & 1 & 68.0 & 167.68 & 1.8 & 41.4 & 56.9 & Silty clay \\
\hline 463 & 21 & 2 & 109.0 & 179.09 & 6.4 & 38.3 & 55.2 & Silty clay \\
\hline 463 & 21 & 4 & 107.0 & 182.07 & 2.8 & 43.8 & 53.4 & Silty clay \\
\hline 463 & 22 & 2 & 40.0 & 187.90 & 2.7 & 34.5 & 62.8 & Silty clay \\
\hline 463 & 22 & 4 & 57.0 & 191.07 & 1.8 & 37.4 & 60.8 & Silty clay \\
\hline 463 & 23 & 1 & 25.0 & 195.75 & 2.7 & 47.6 & 49.7 & Silty clay \\
\hline 463 & 24 & 2 & 116.0 & 202.16 & 1.0 & 36.0 & 63.1 & Silty clay \\
\hline 463 & 25 & 2 & 40.0 & 206.90 & 5.5 & 53.0 & 41.5 & Clayey silt \\
\hline 463 & 26 & 2 & 87.0 & 216.87 & 8.0 & 56.1 & 35.9 & Clayey silt \\
\hline 463 & 26 & 4 & 92.0 & 219.92 & 7.7 & 56.5 & 35.8 & Clayey silt \\
\hline 463 & 27 & 2 & 24.0 & 225.74 & 17.8 & 47.9 & 34.3 & Clayey silt \\
\hline 463 & 29 & 1 & 52.0 & 243.52 & 9.4 & 50.5 & 40.1 & Clayey silt \\
\hline 463 & 30 & 1 & 66.0 & 253.16 & 11.0 & 28.1 & 60.9 & Silty clay \\
\hline 463 & 34 & 2 & 42.0 & 292.42 & 6.2 & 56.7 & 37.1 & Clayey silt \\
\hline 463 & 35 & $\mathrm{CC}$ & 14.0 & 300.44 & 5.2 & 37.6 & 57.2 & Silty clay \\
\hline 463 & 38 & 1 & 10.0 & 328.60 & 1.2 & 42.7 & 56.1 & Silty clay \\
\hline 463 & 43 & 2 & 40.0 & 377.90 & 1.8 & 21.4 & 76.8 & Clay \\
\hline 463 & 43 & 4 & 40.0 & 380.90 & 1.5 & 26.1 & 72.4 & Silty clay \\
\hline 463 & 48 & 2 & 100.0 & 426.00 & 4.7 & 23.2 & 72.1 & Silty clay \\
\hline 463 & 55 & 1 & 92.0 & 481.42 & 10.8 & 39.3 & 49.8 & Silty clay \\
\hline
\end{tabular}




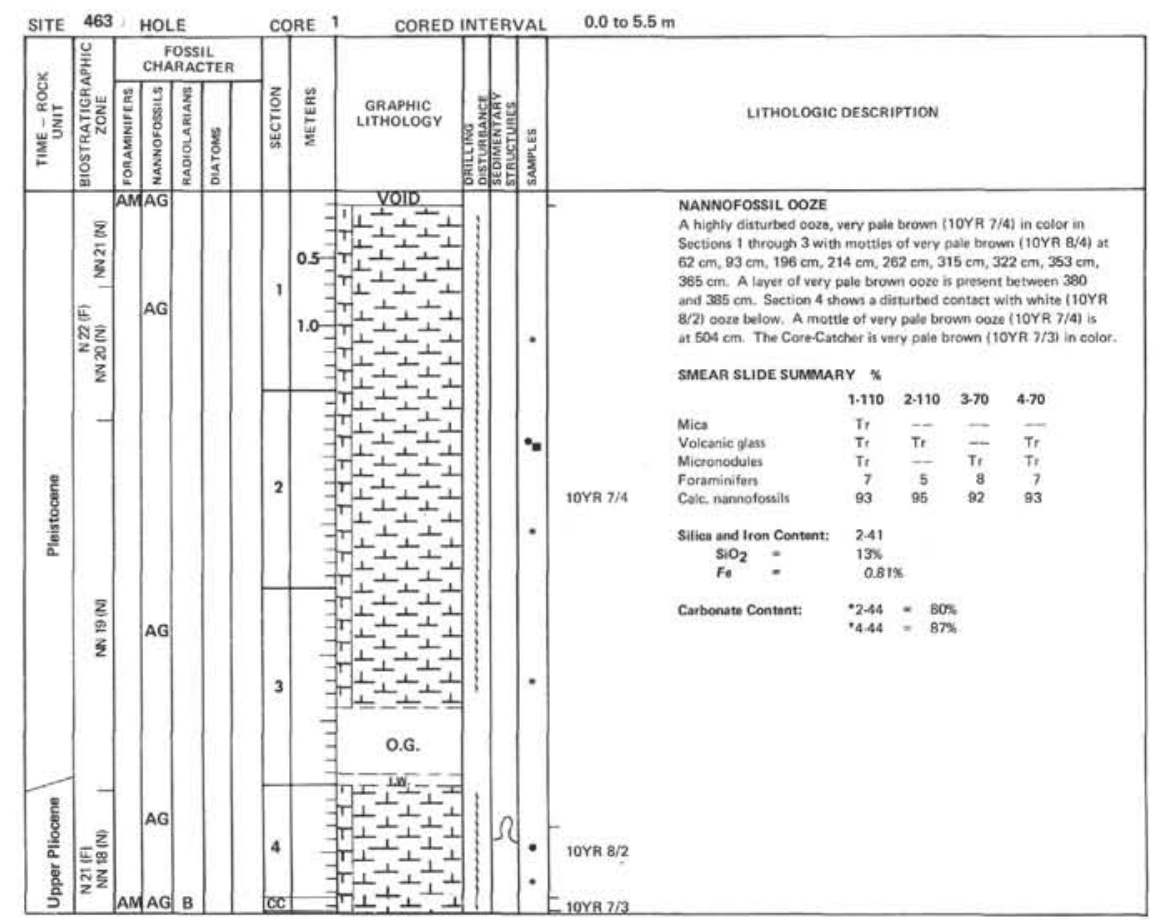

Information on core description sheets, for ALL sites, represents field notes taken aboard ship under time pressure. Some of this information has been refined in accord with postcruise findings, but production schedules prohibit definitive correlation of these sheets with subsequent findings. Thus the reader should be alerted to the occasional ambiguity or

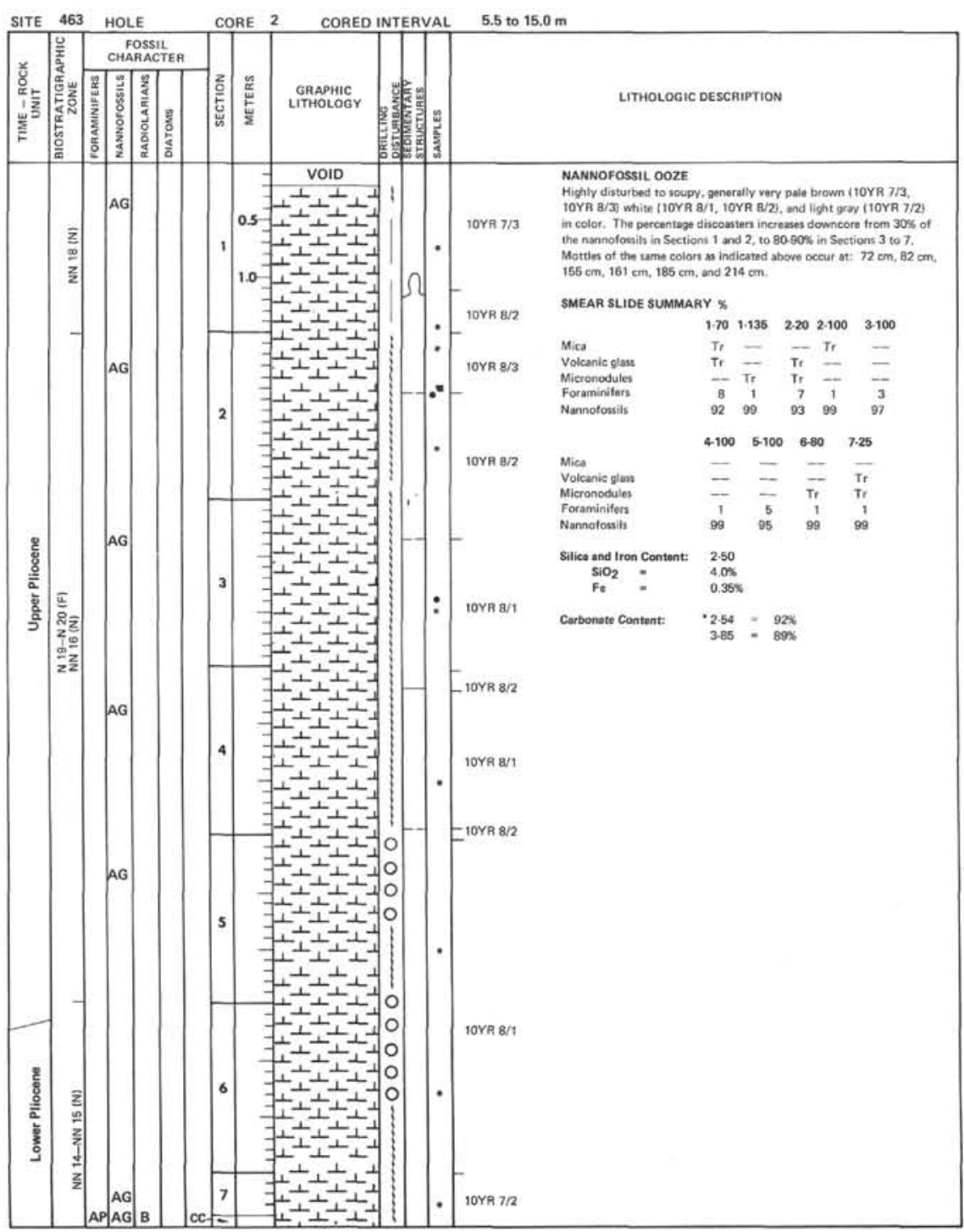



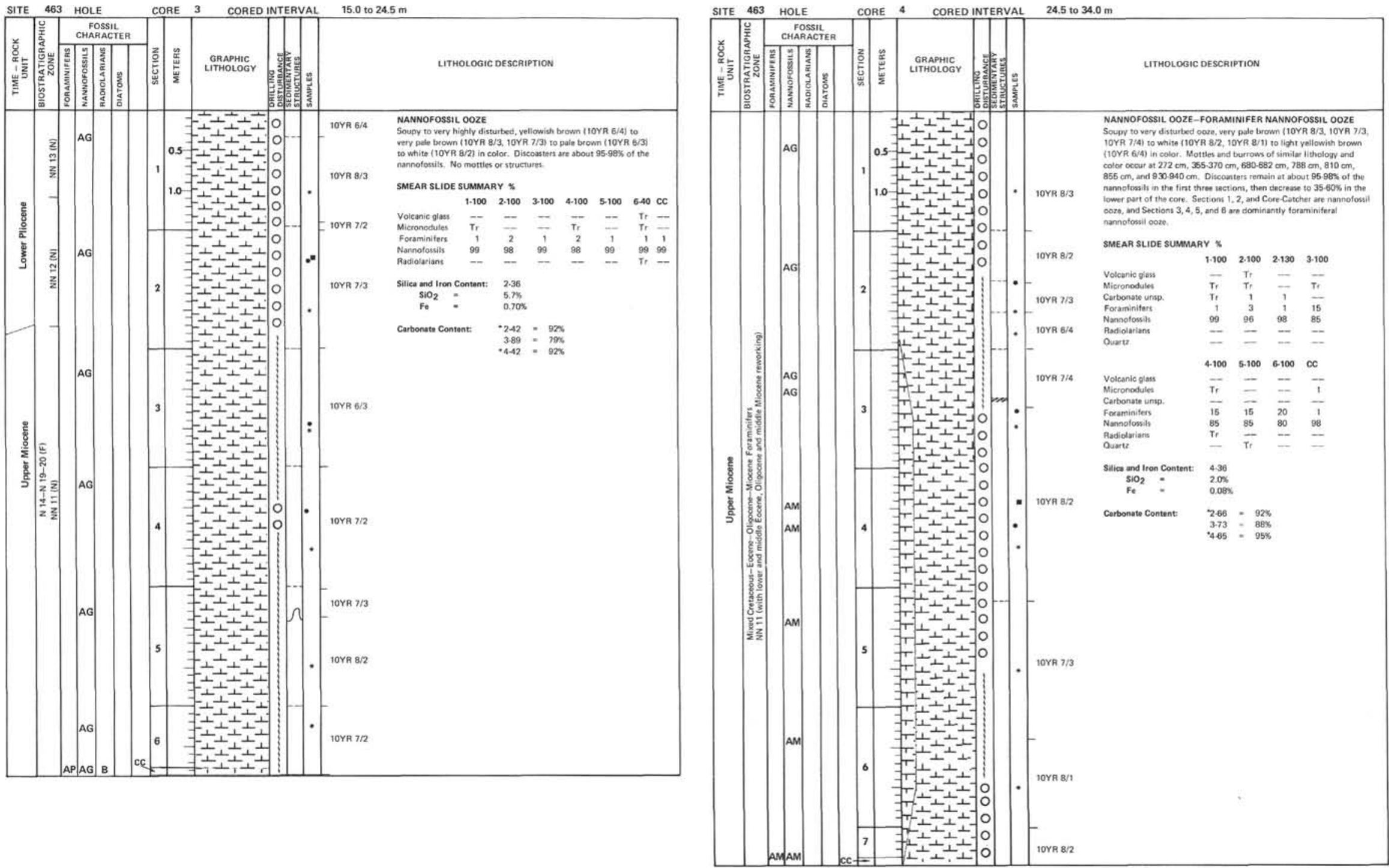

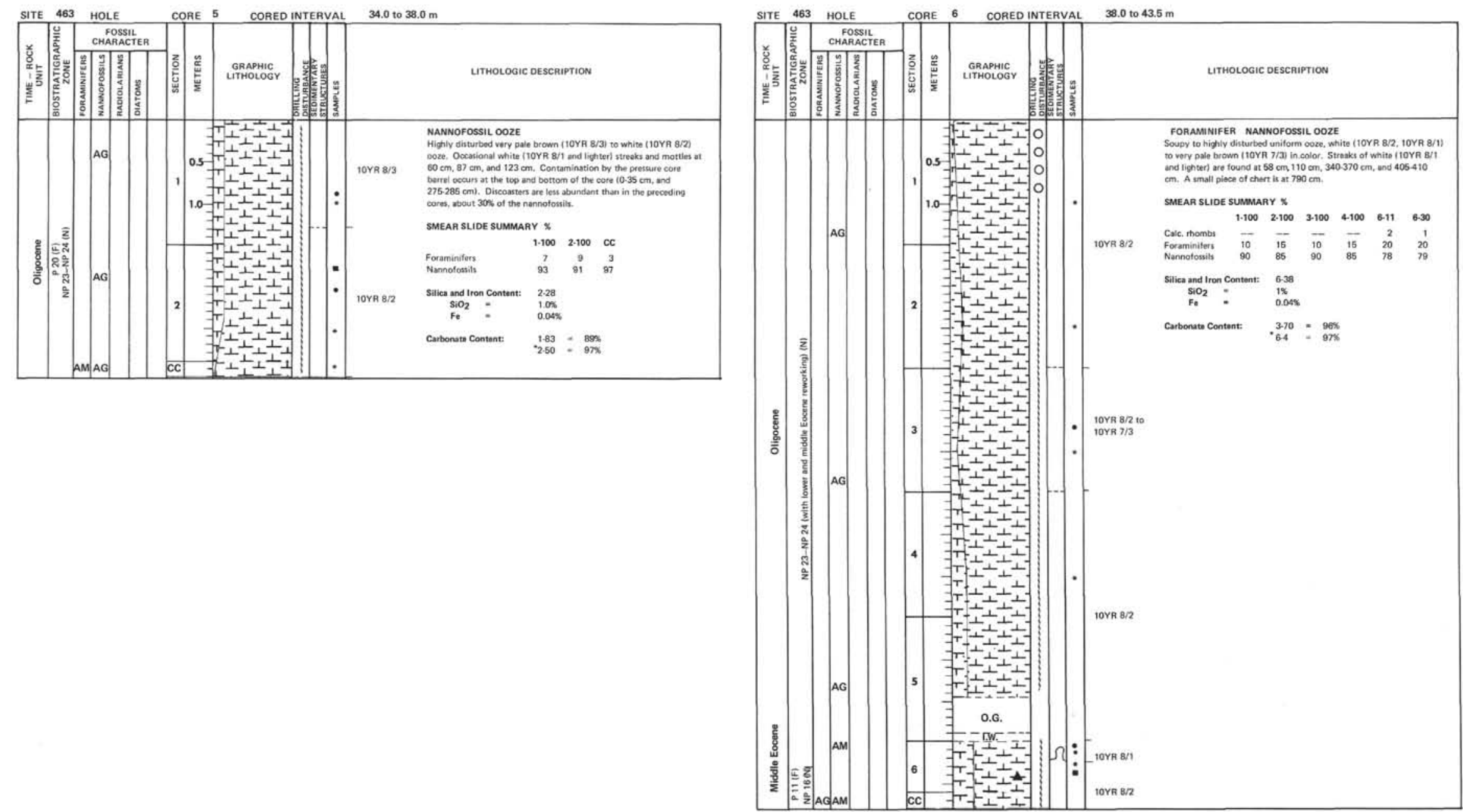

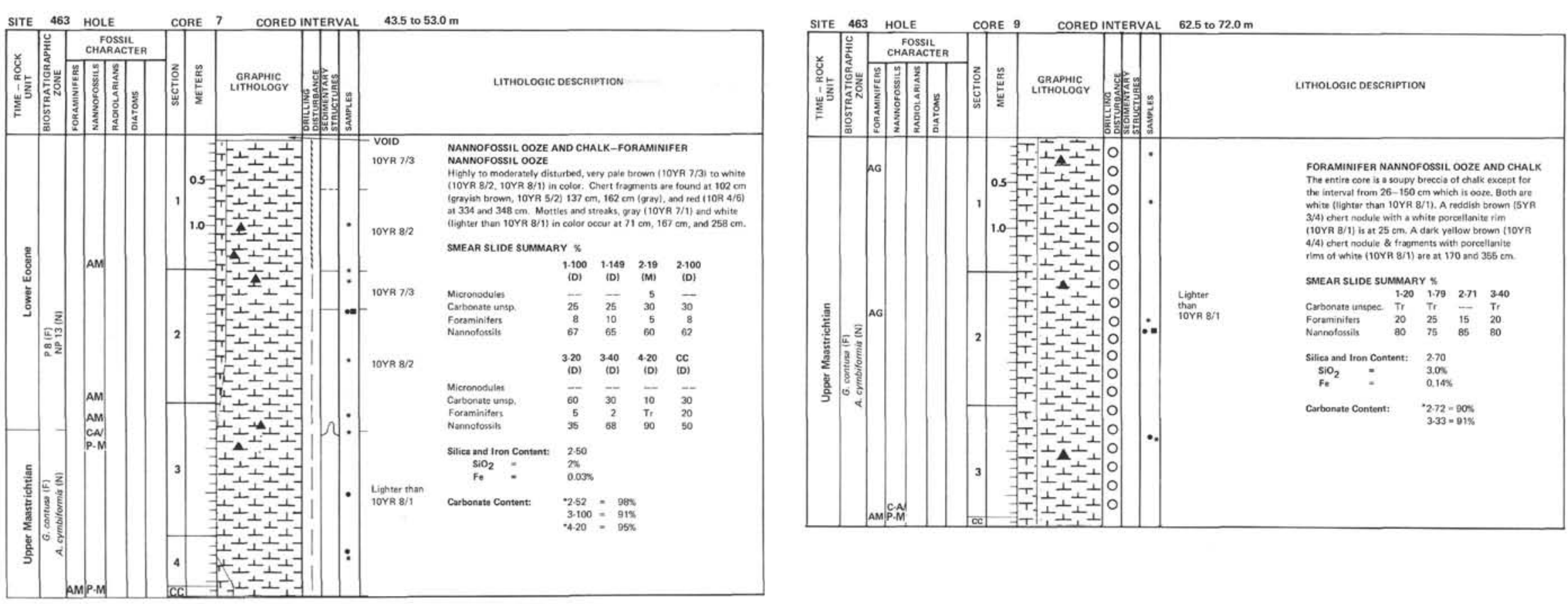

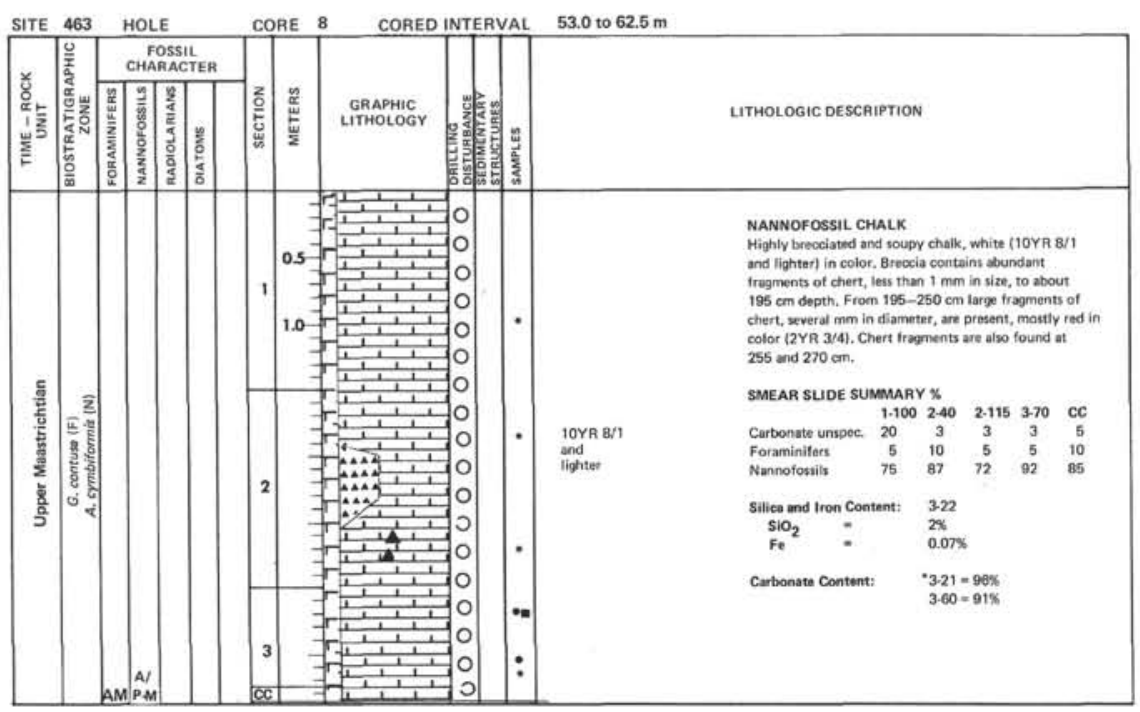



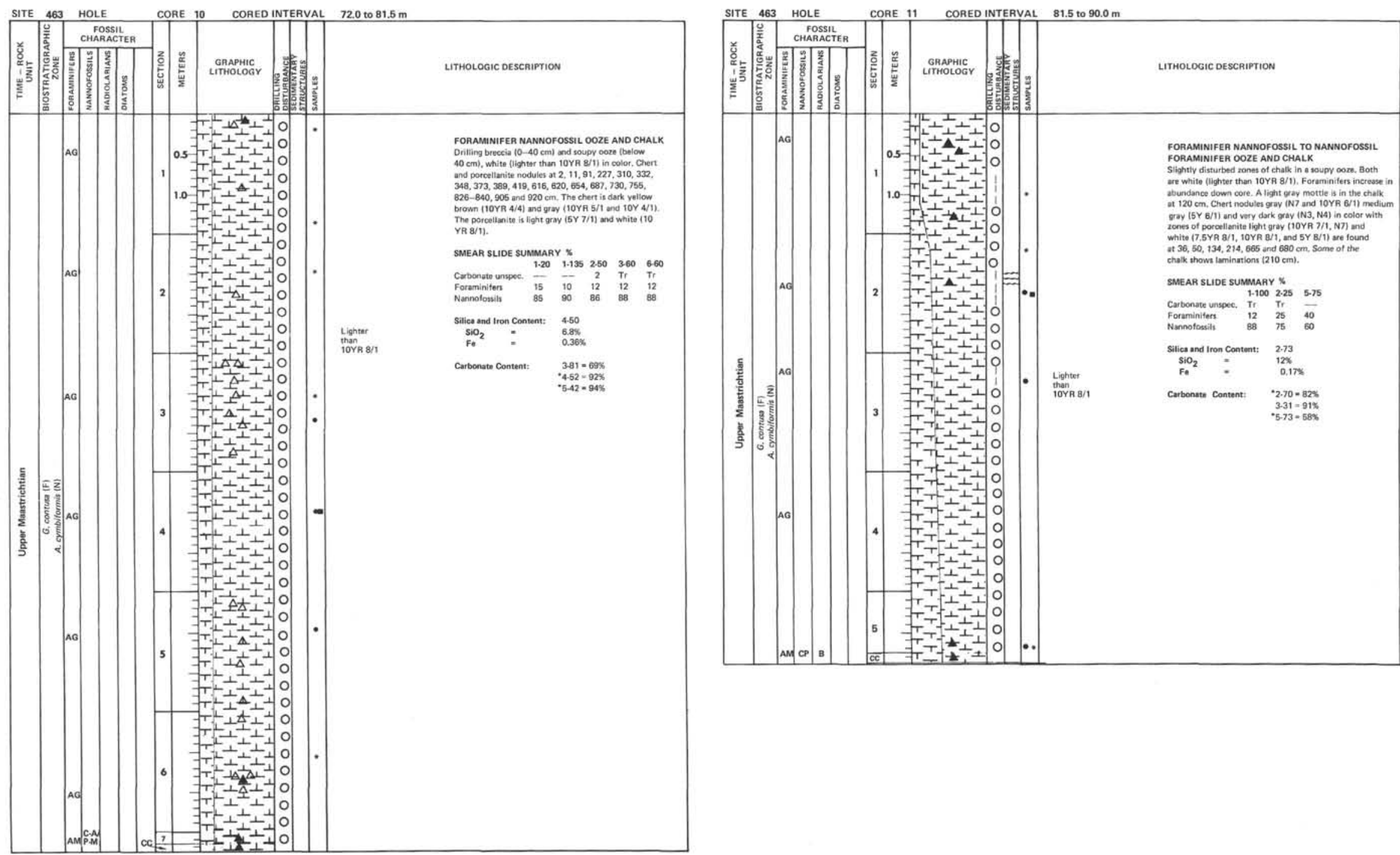

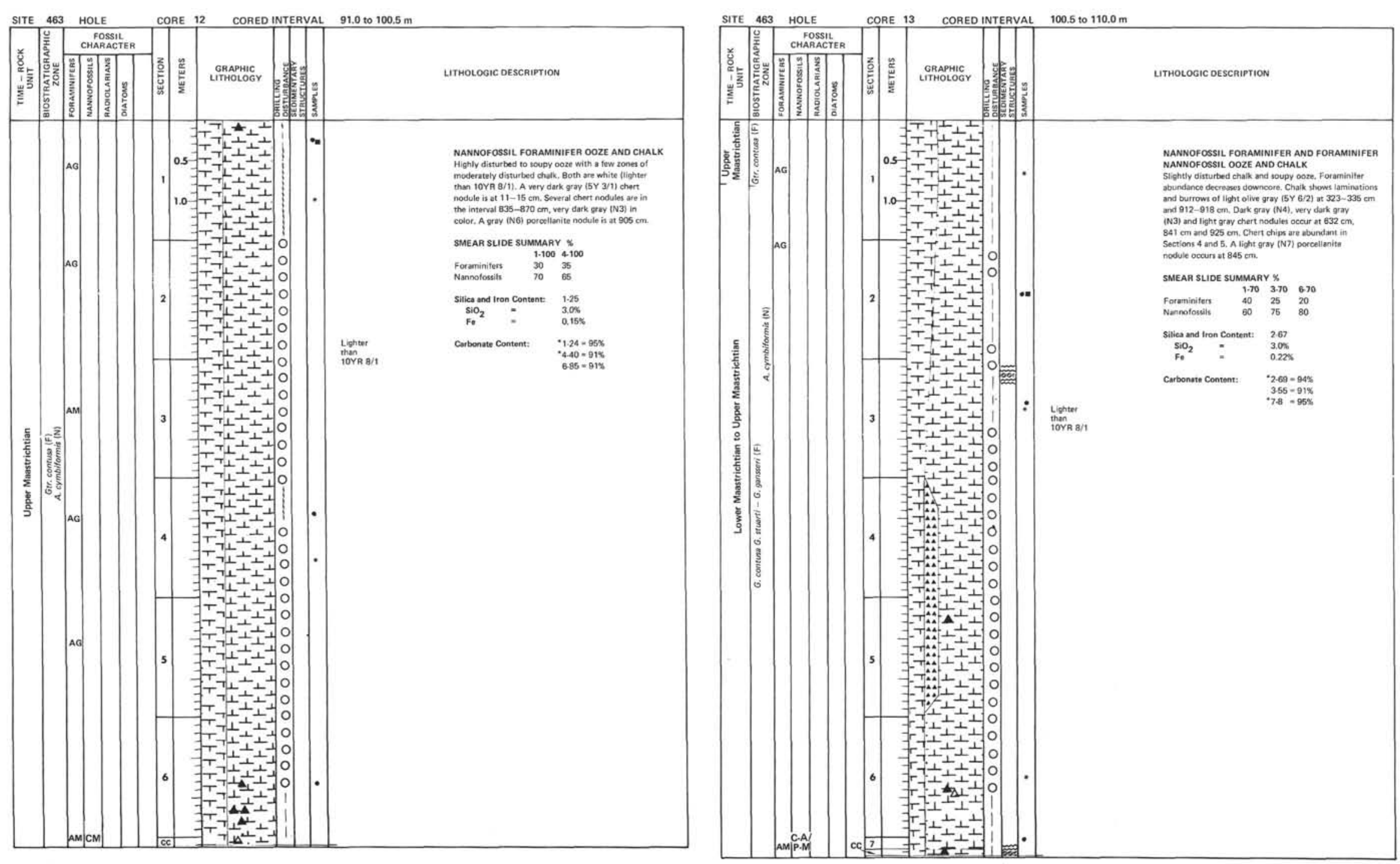

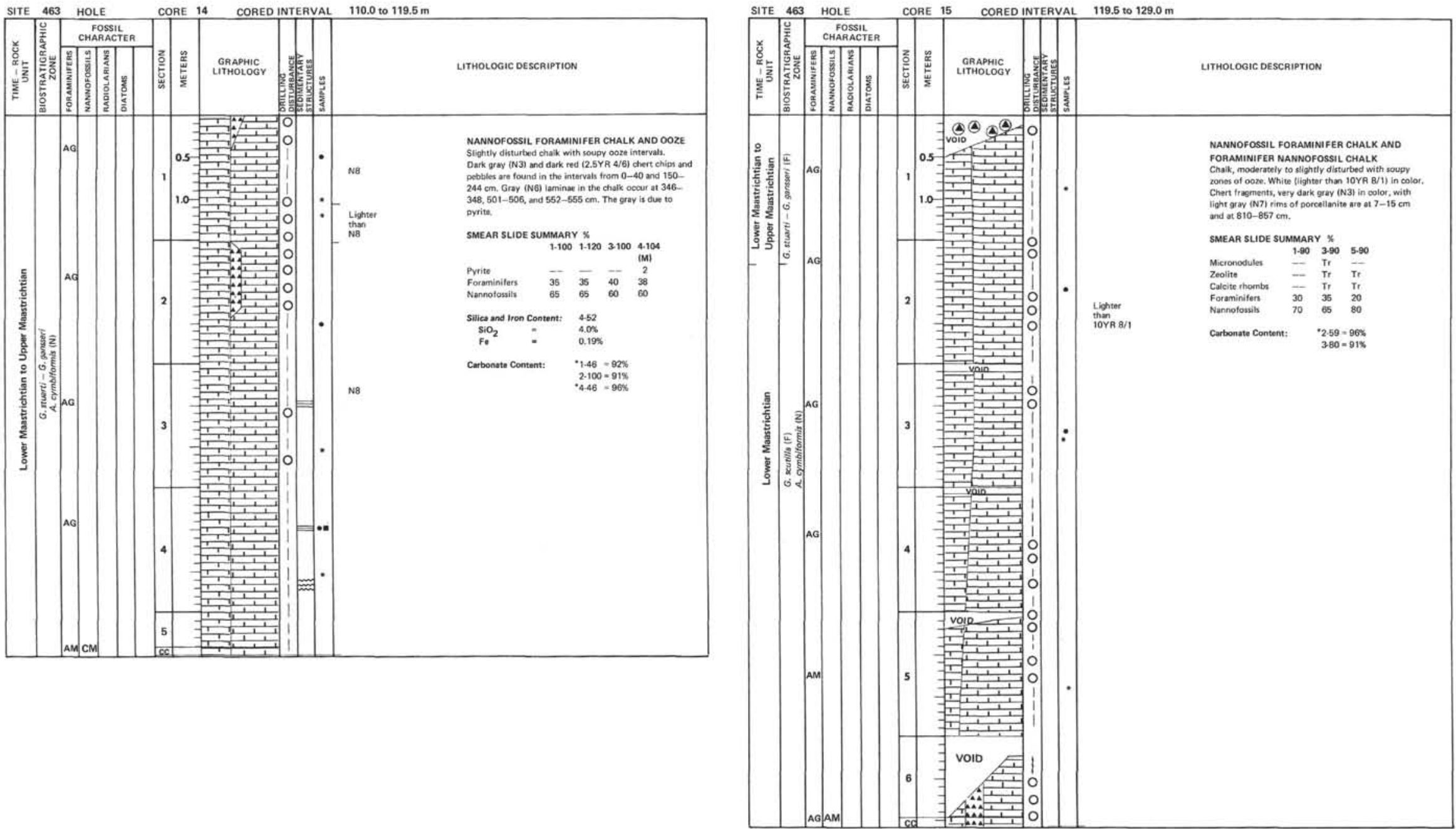

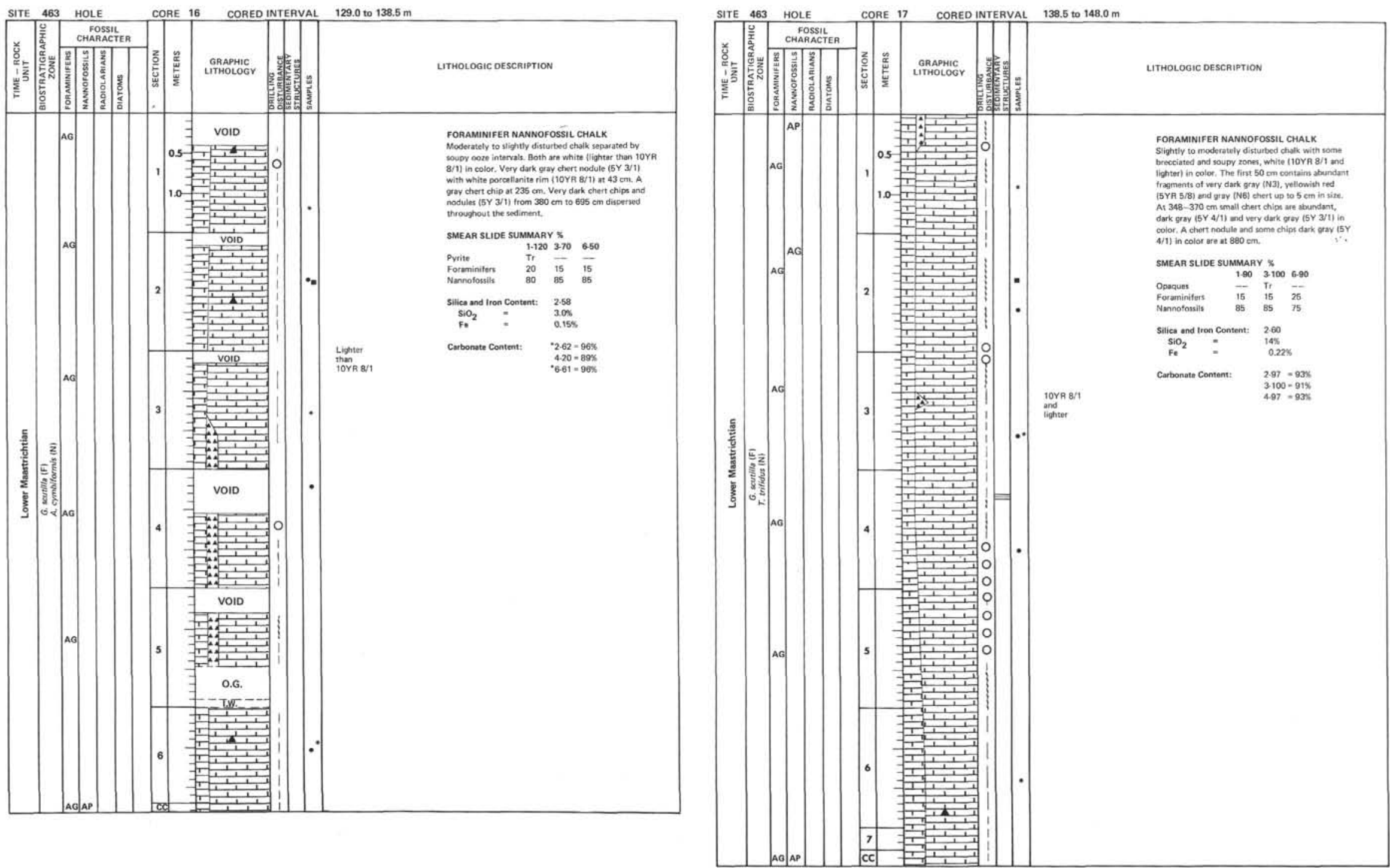


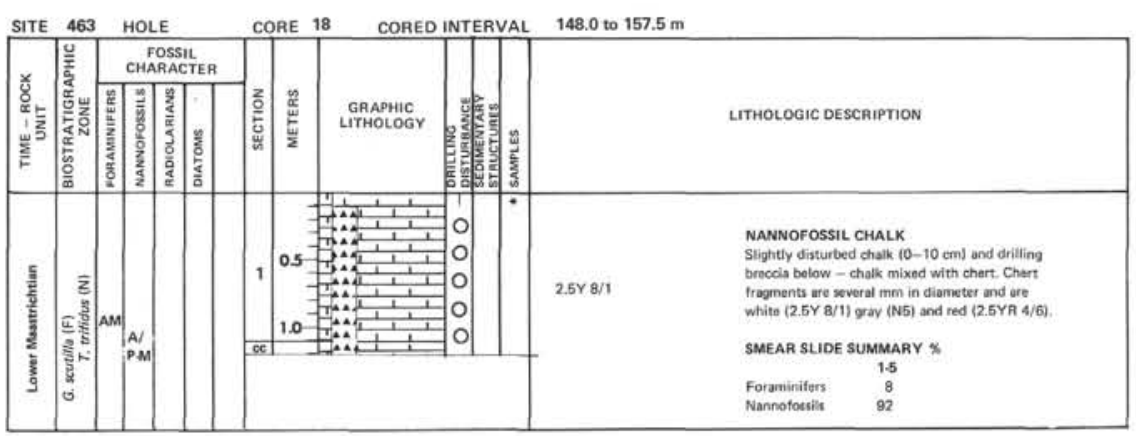

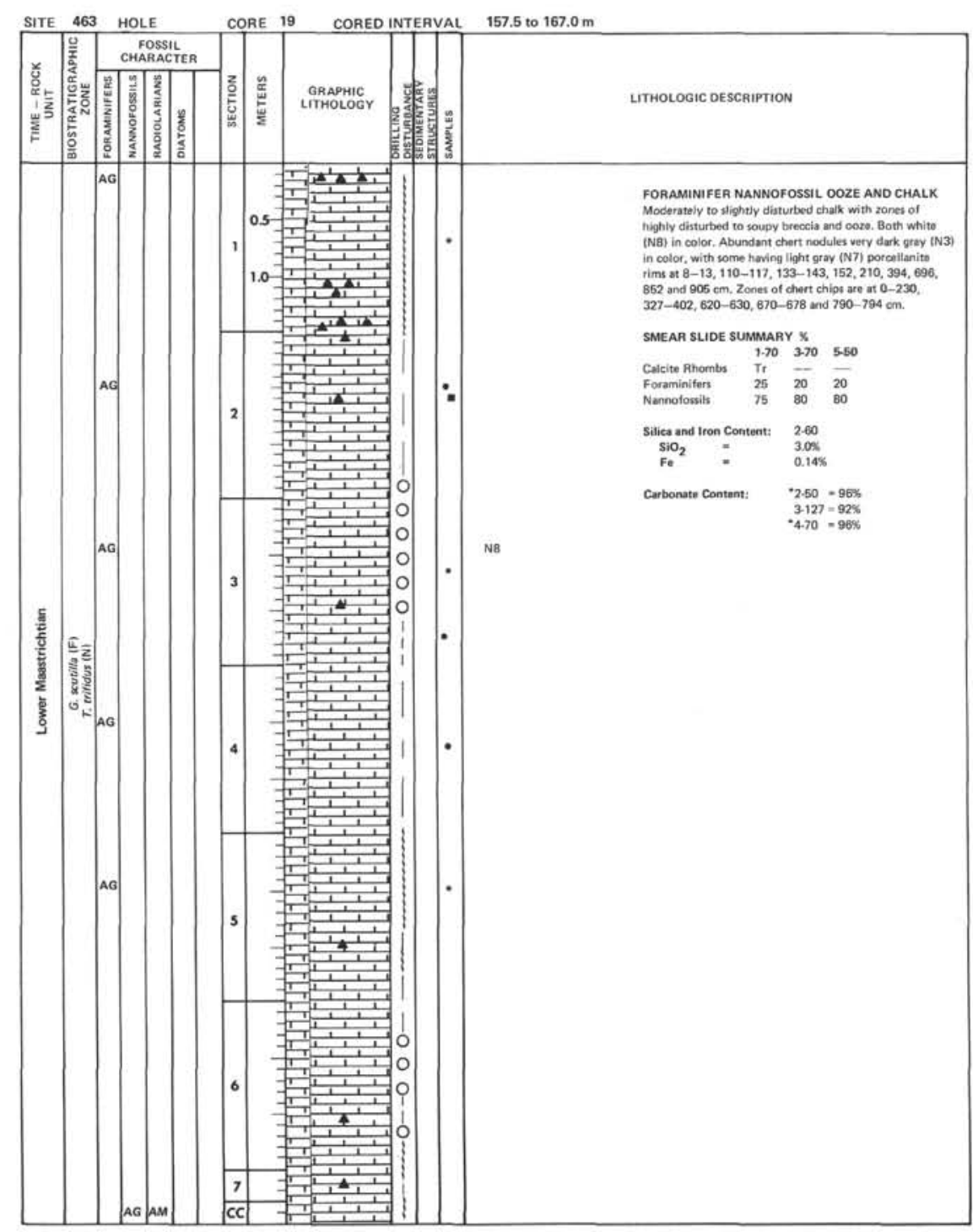



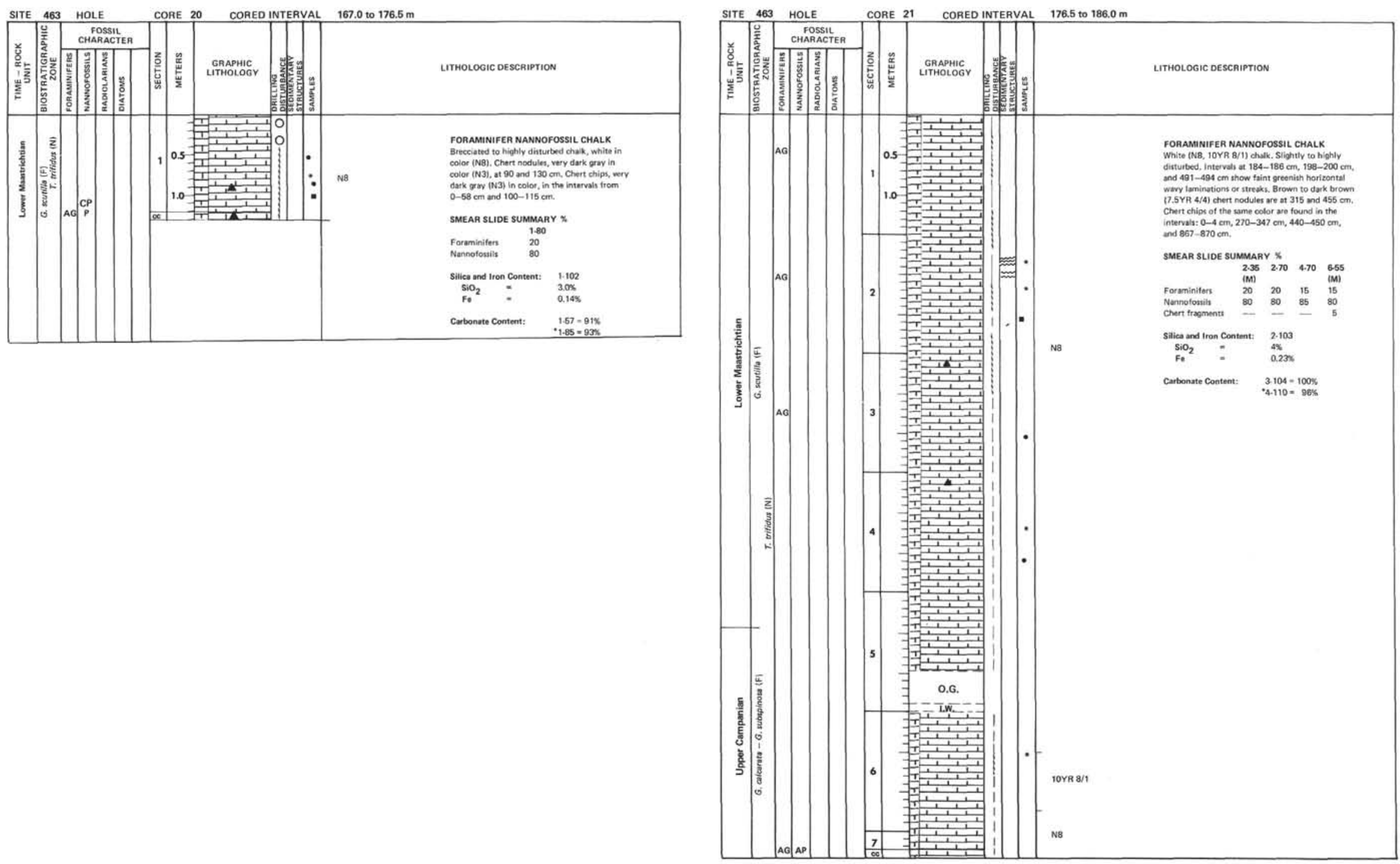

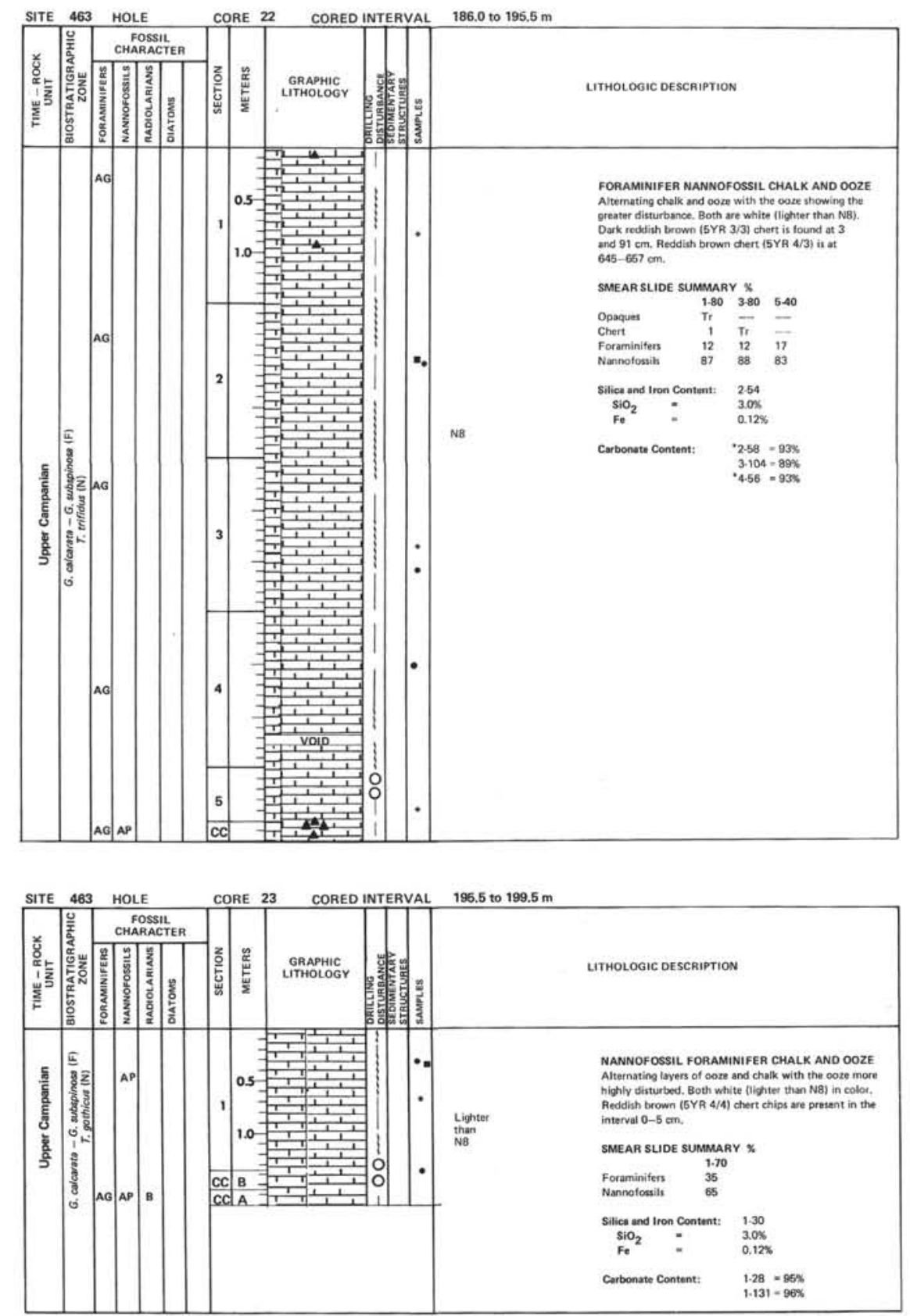
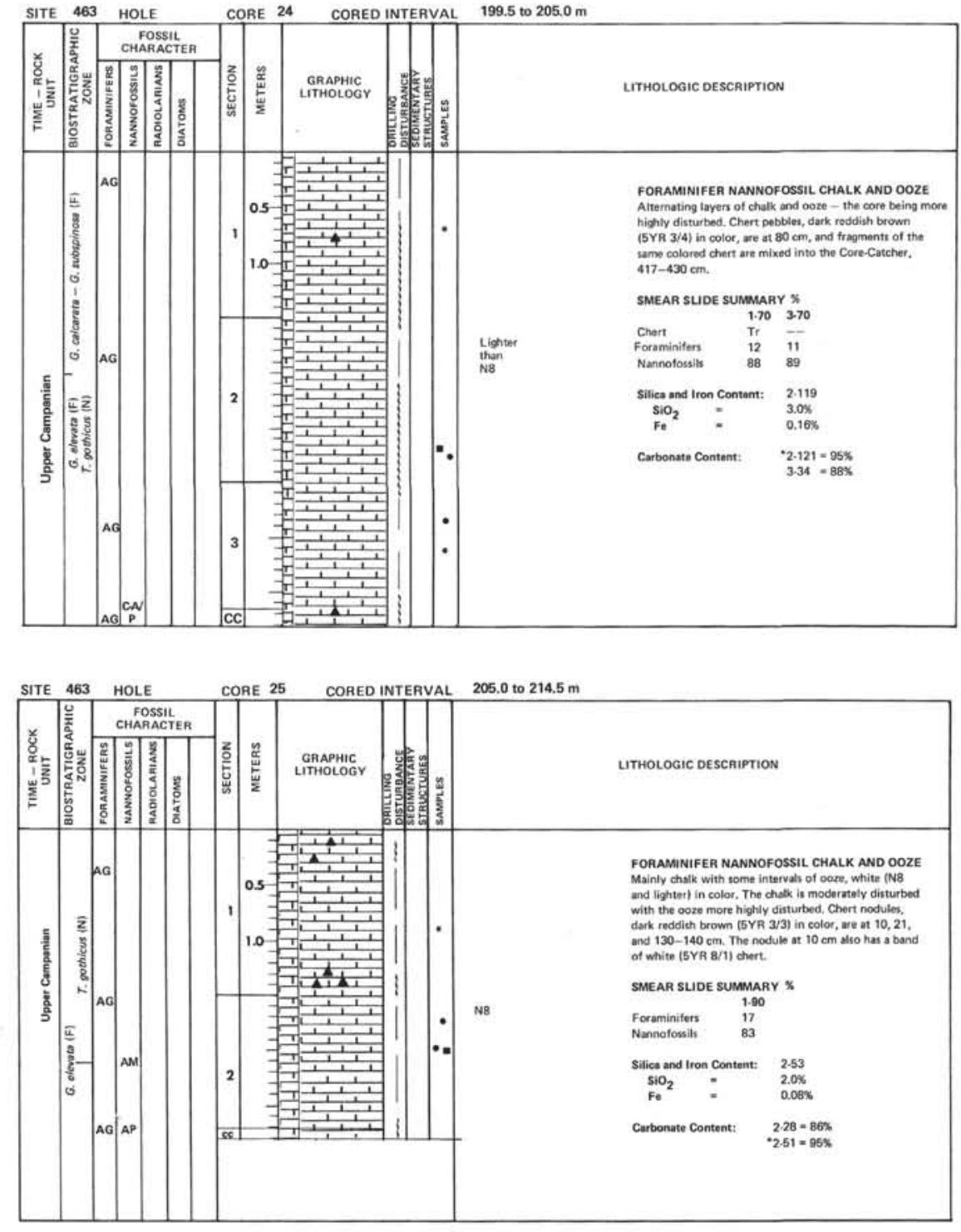

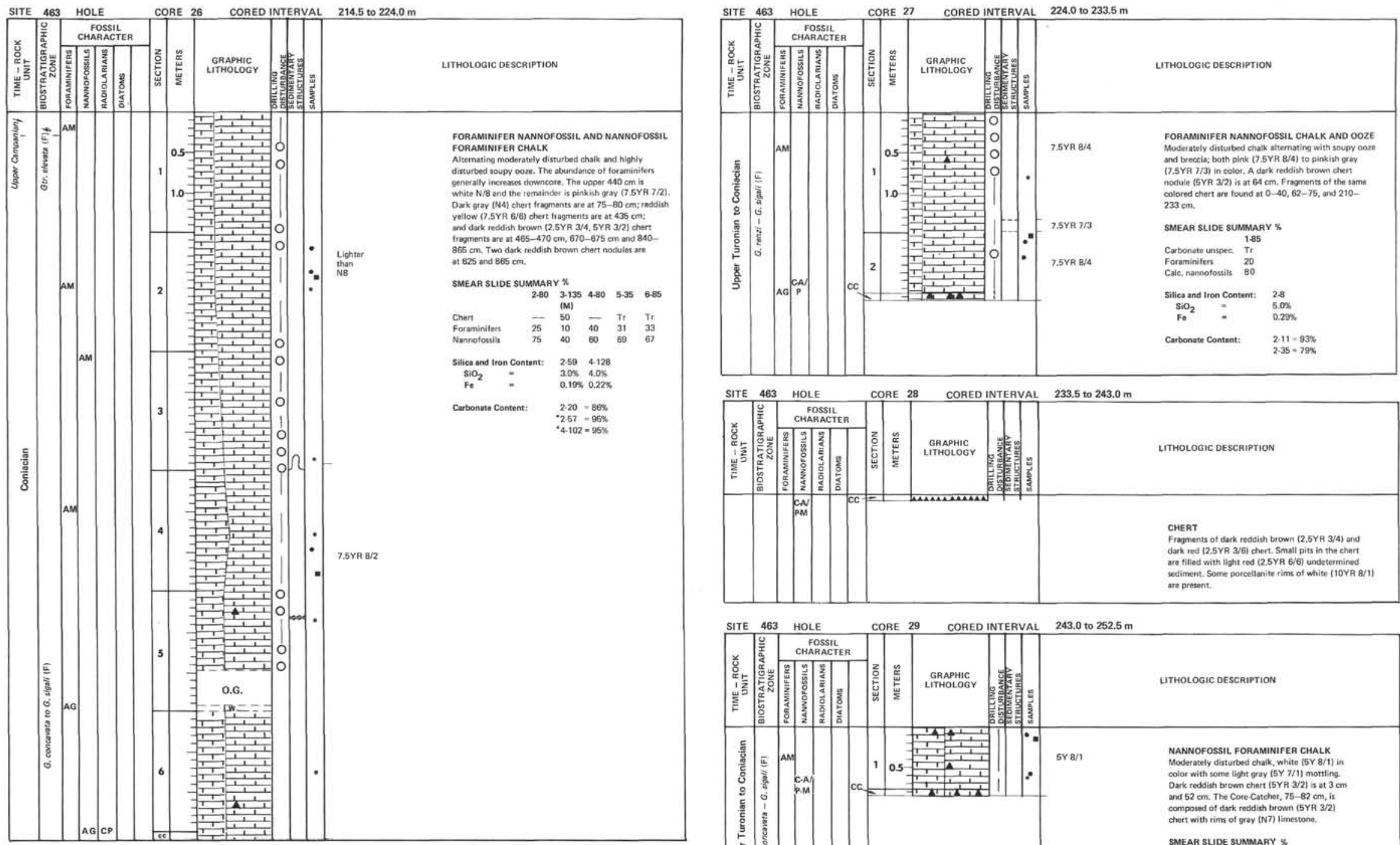

\begin{tabular}{|c|c|c|c|c|}
\hline SITE & 463 \\
\hline
\end{tabular}

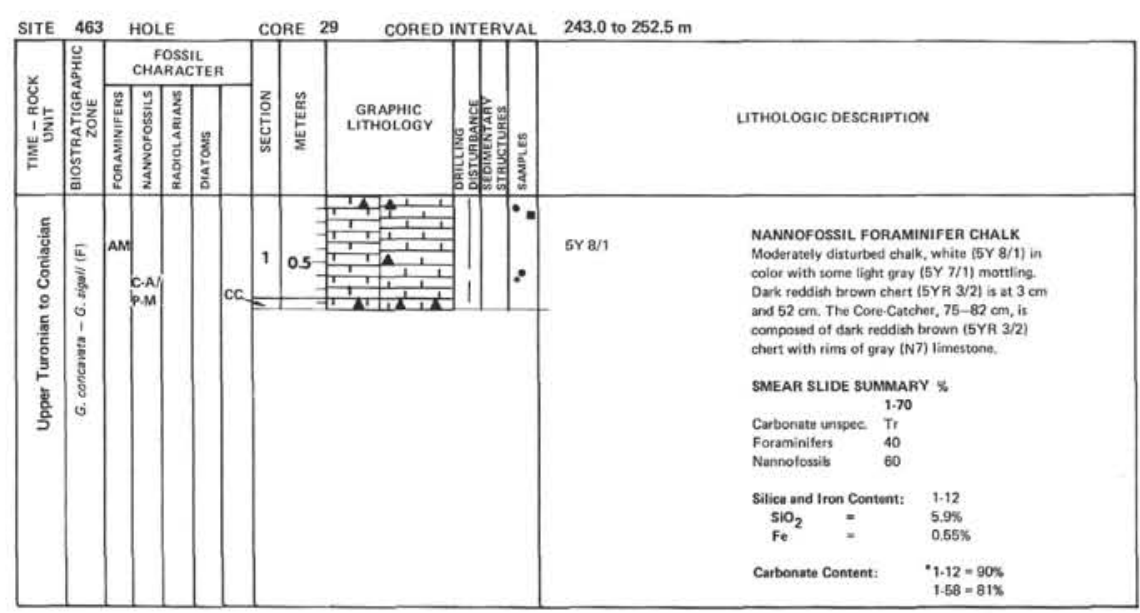



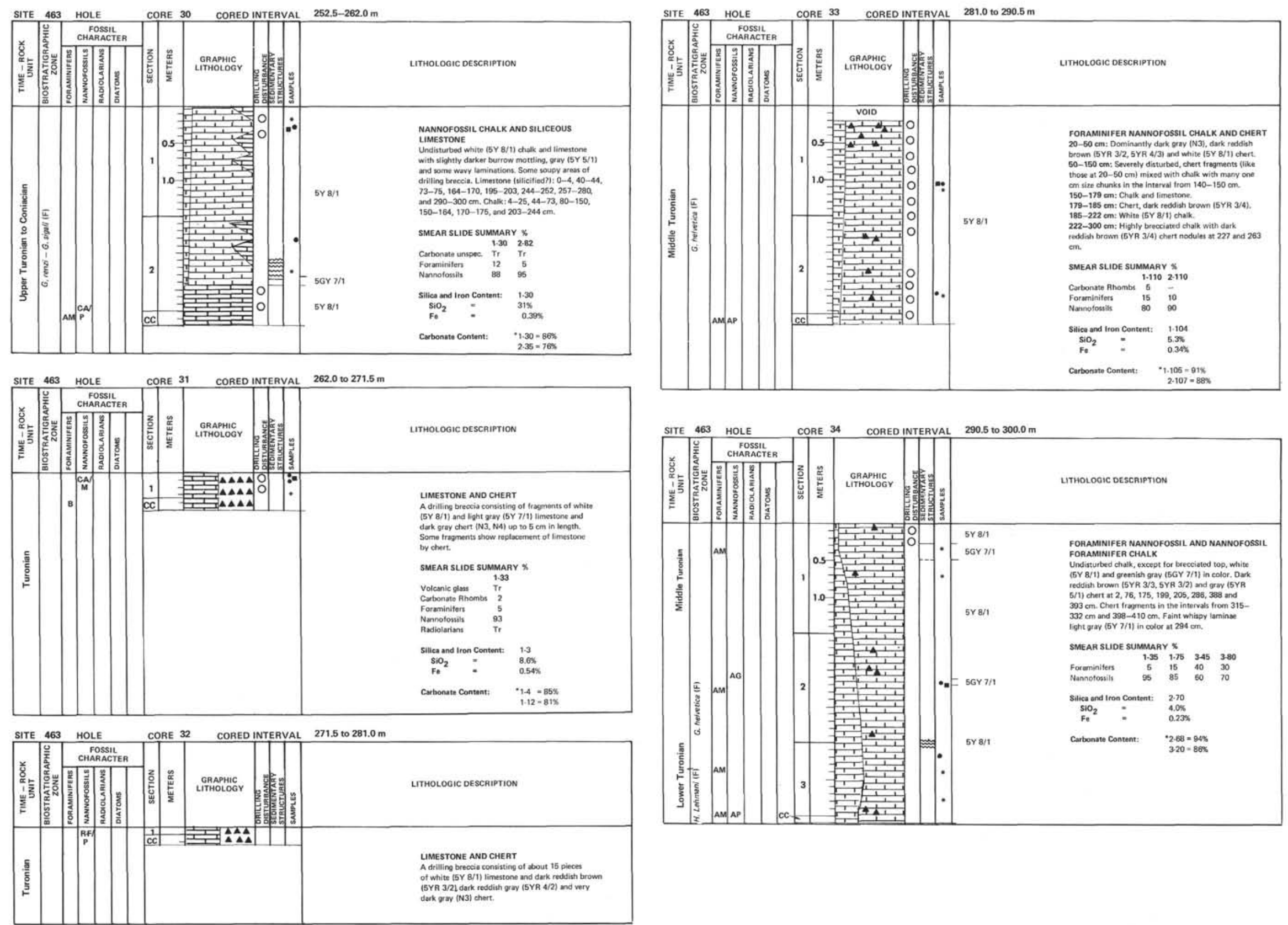

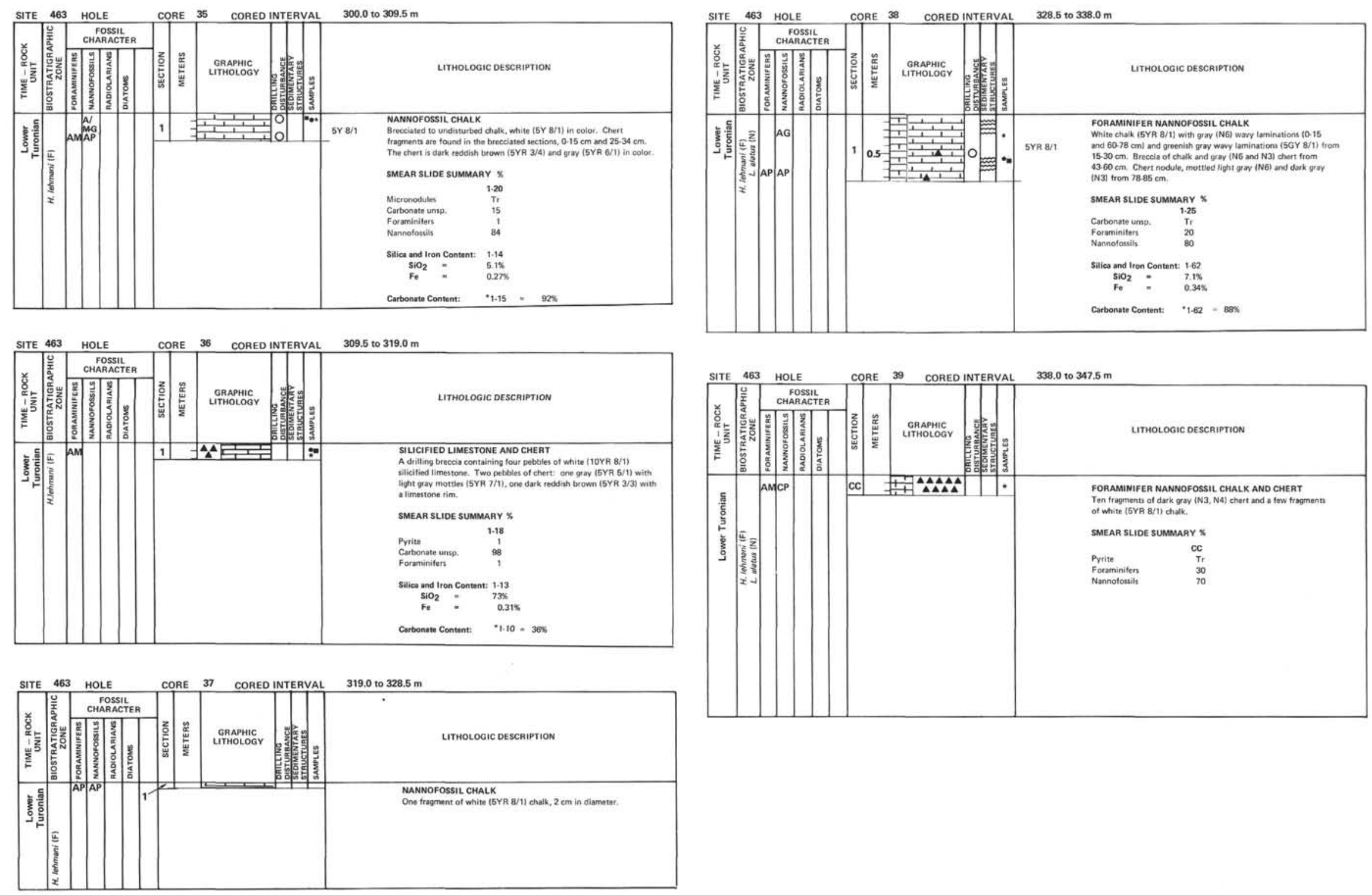

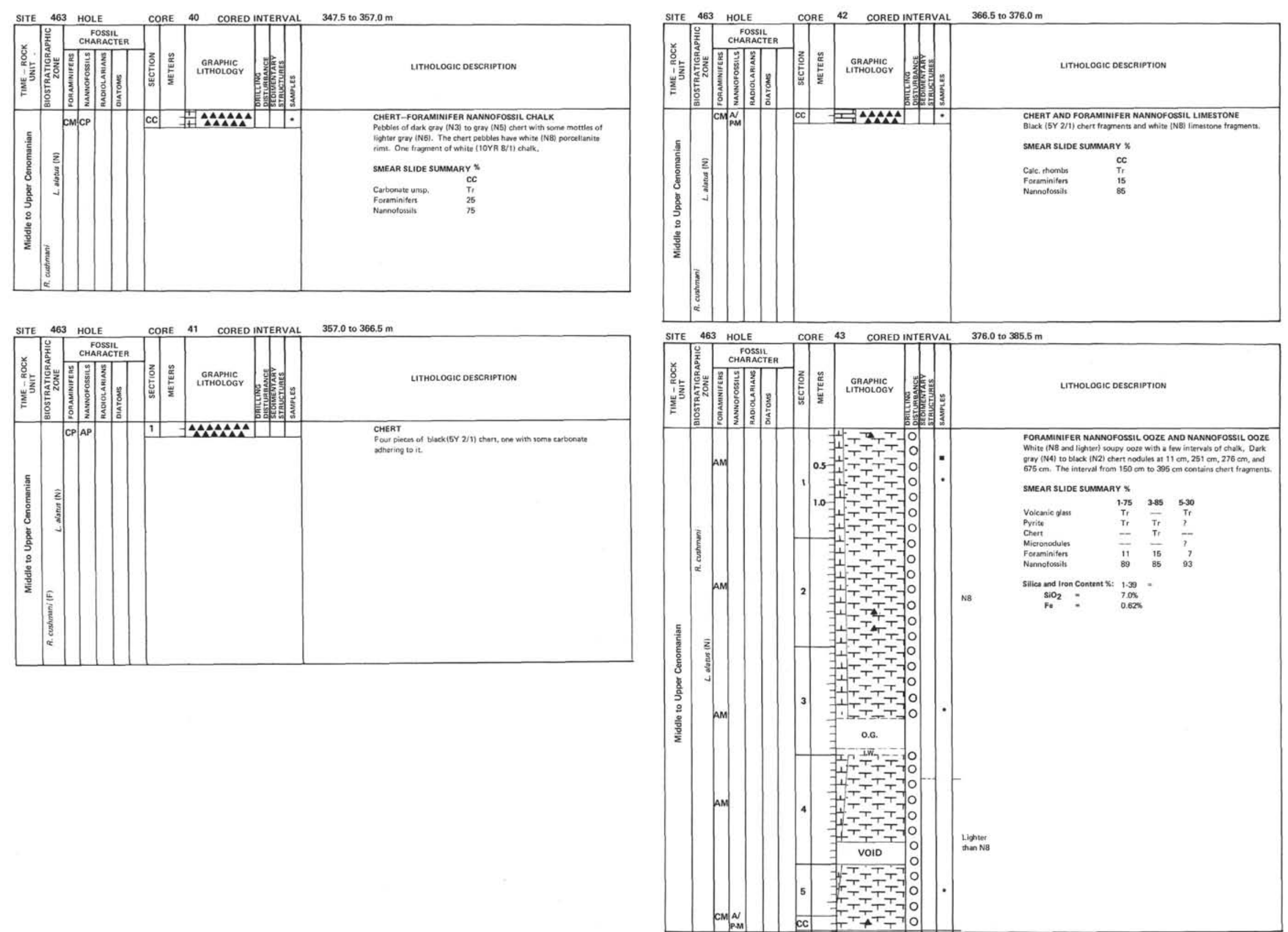

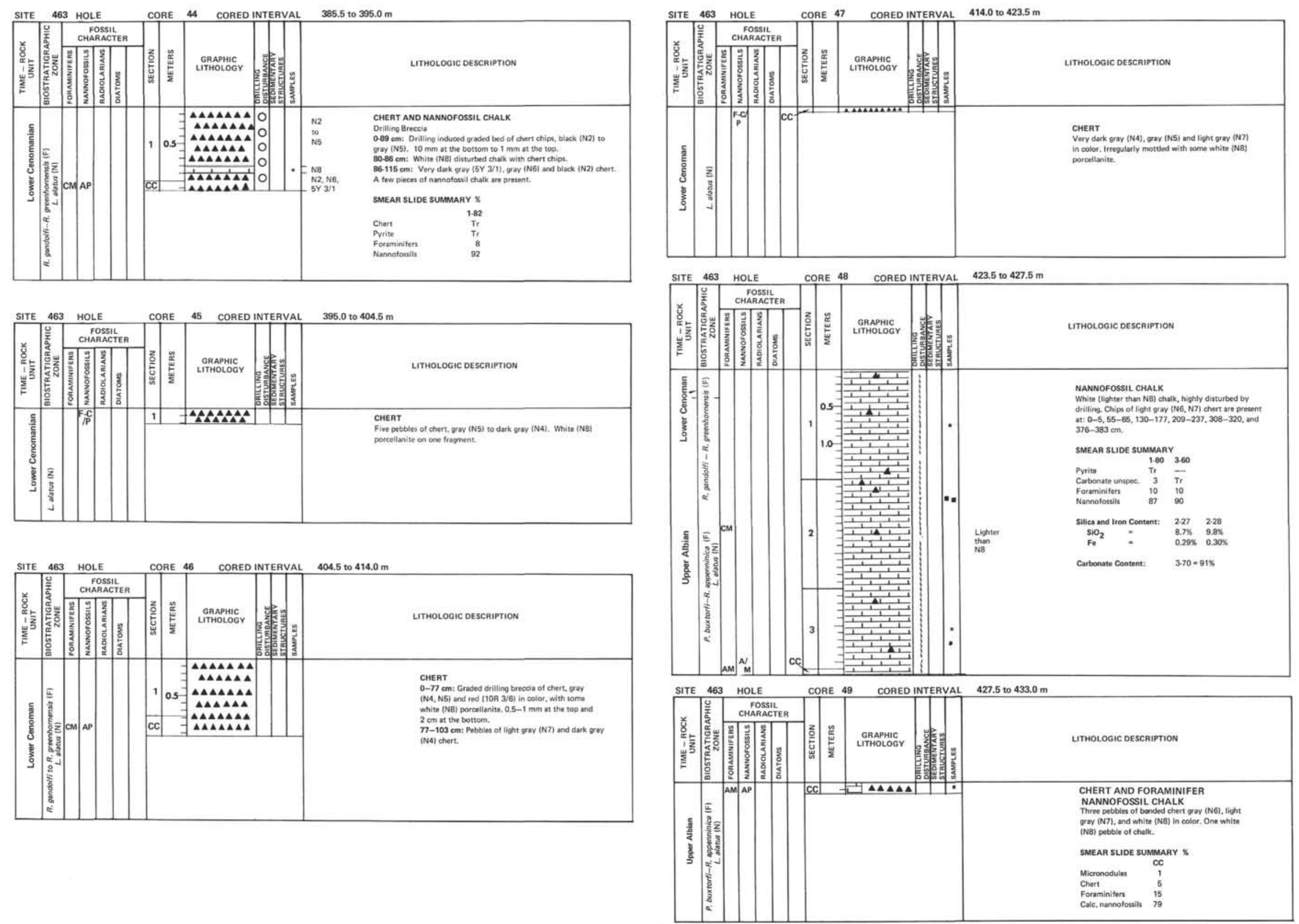

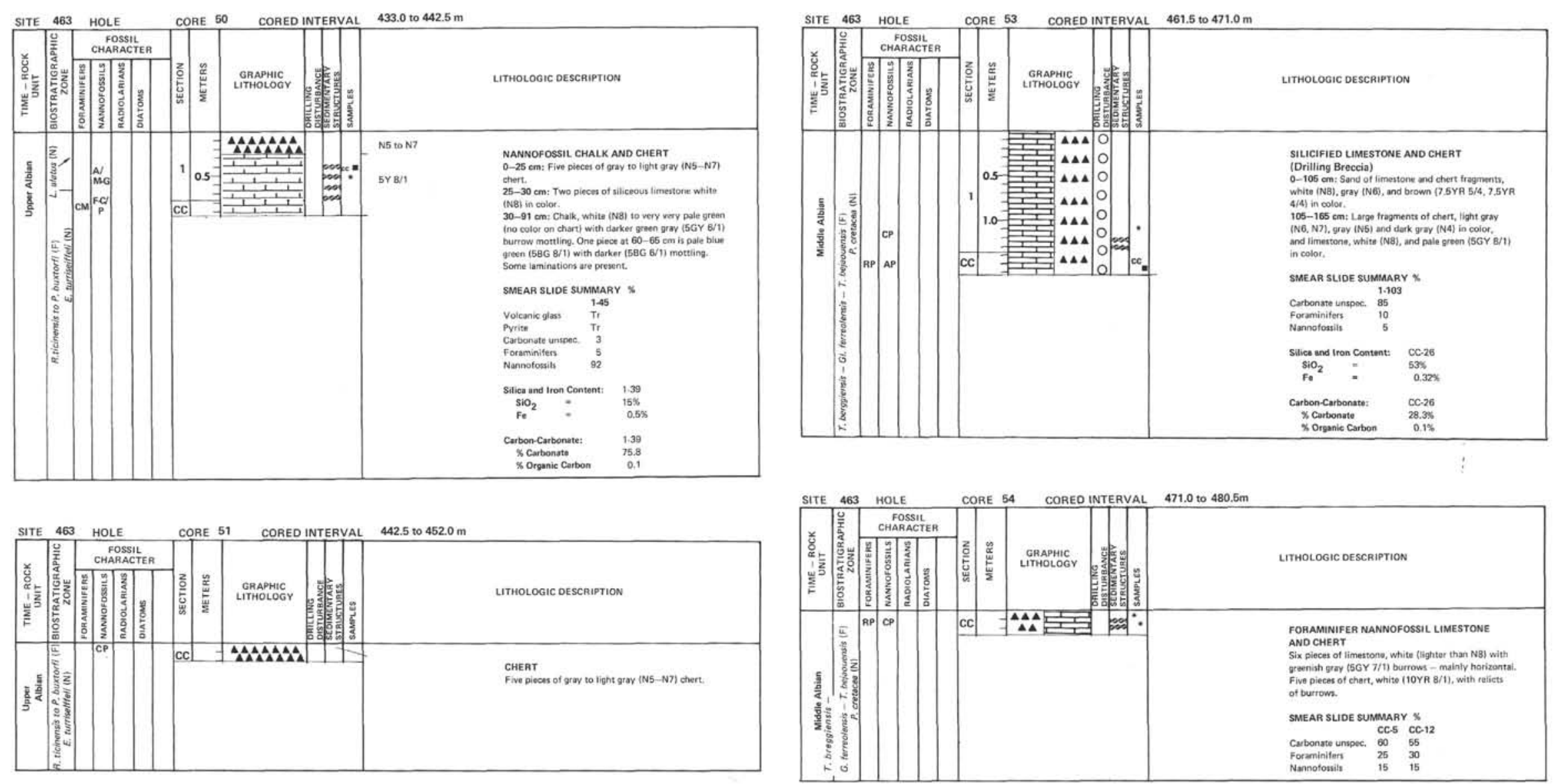

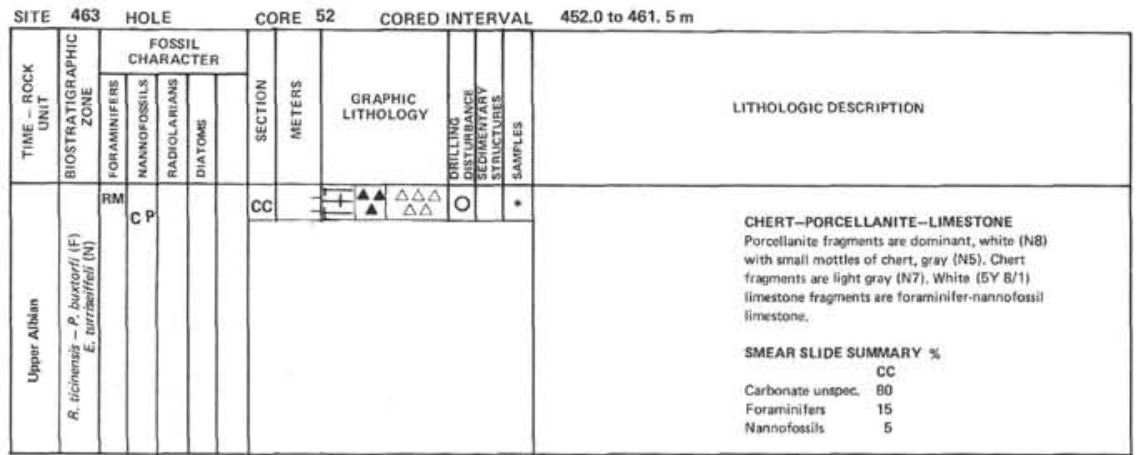



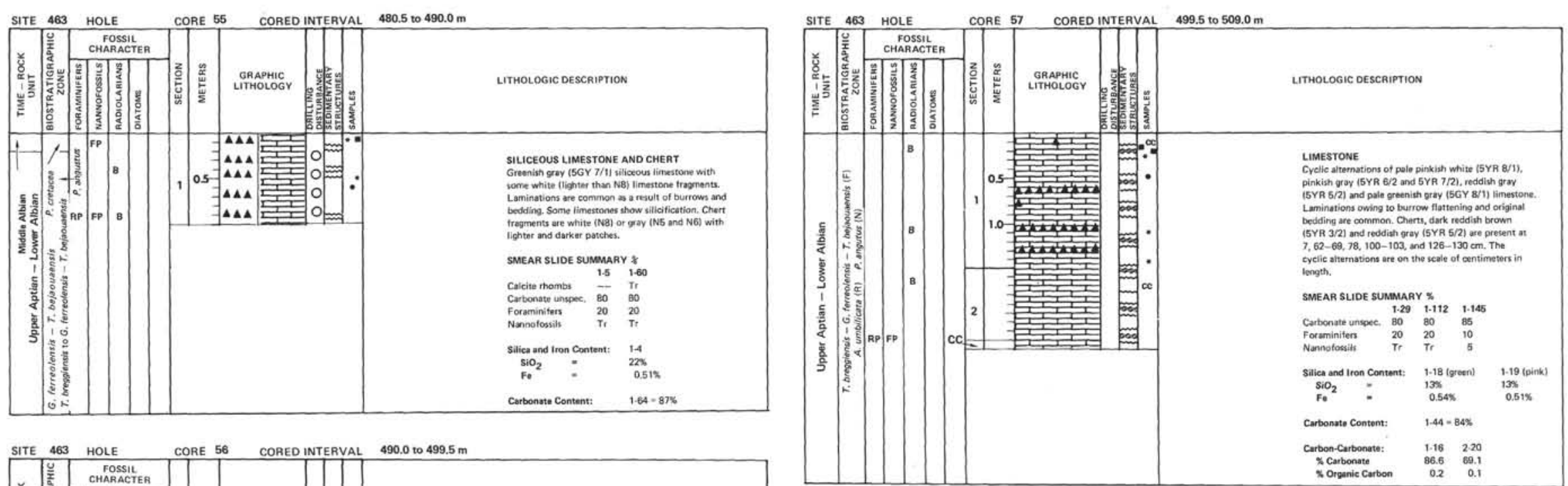

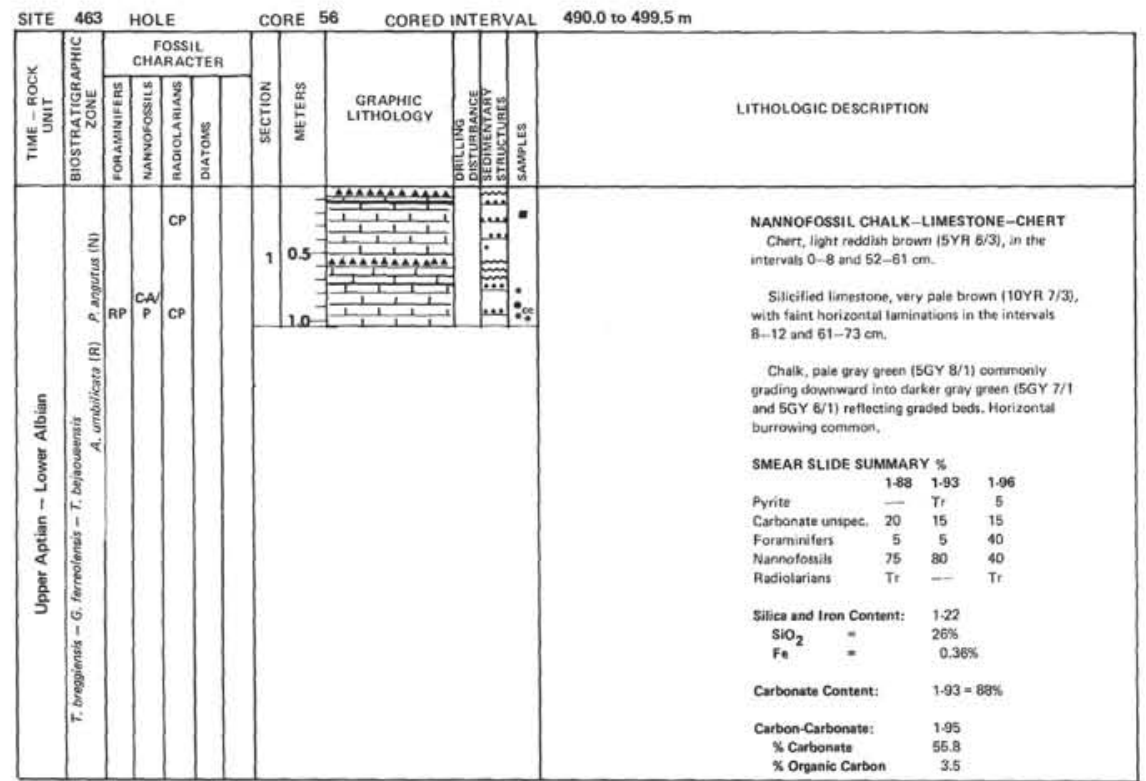

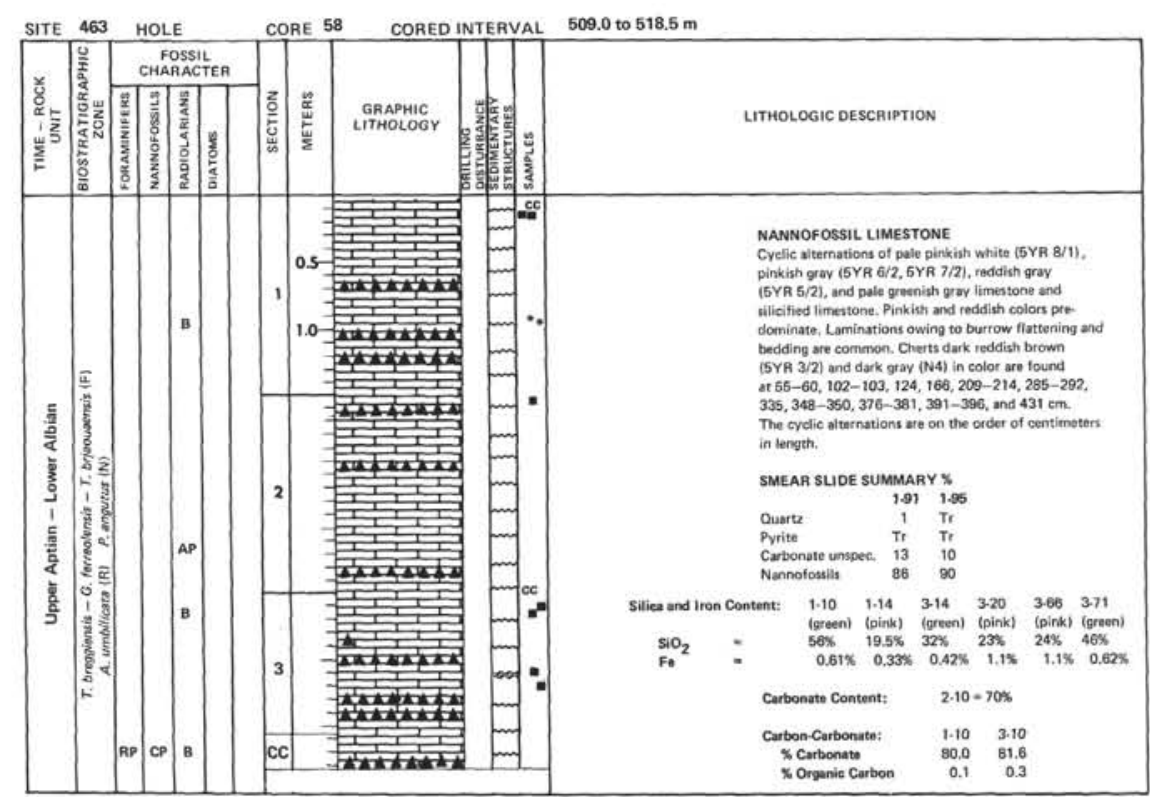



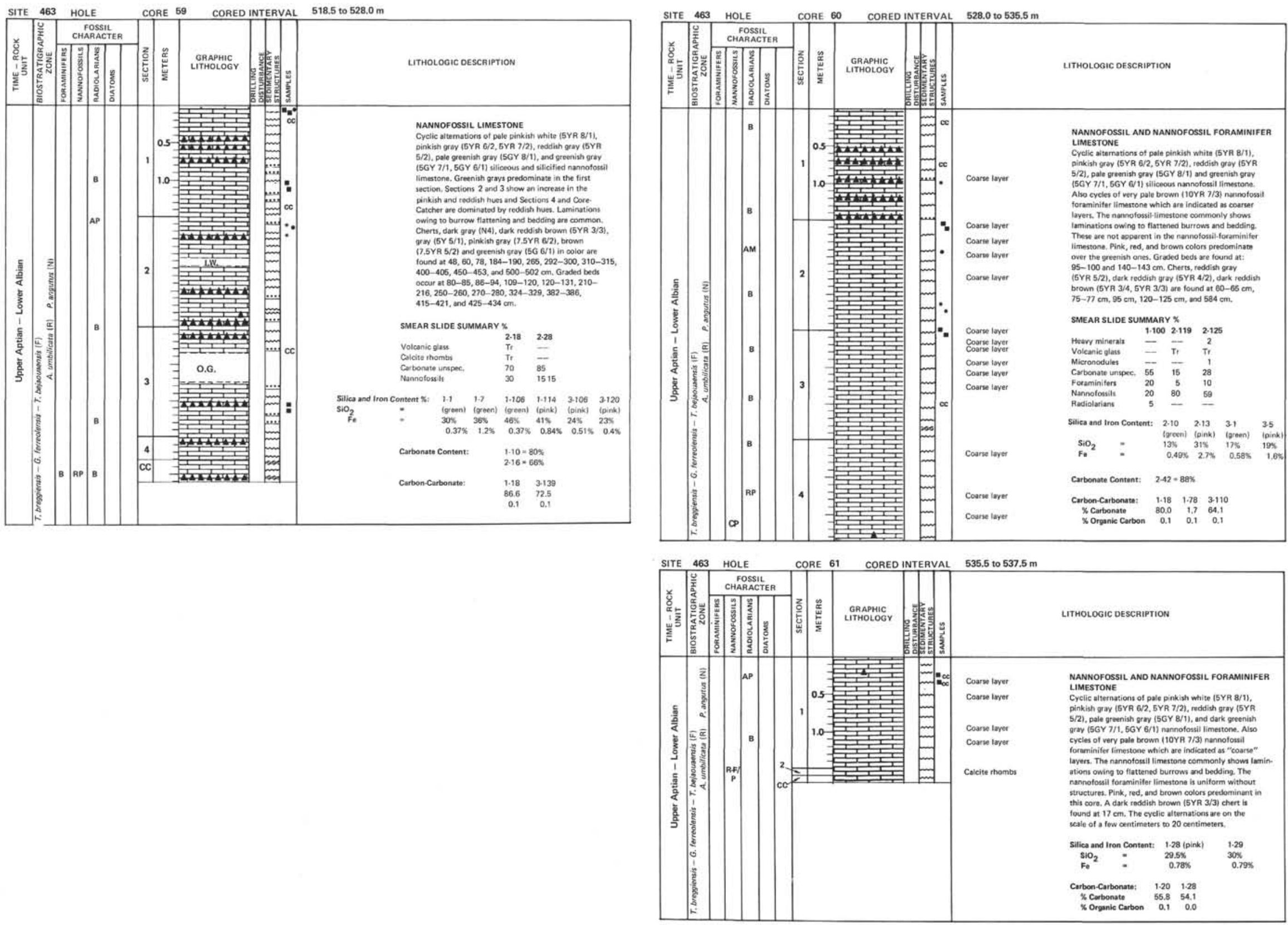

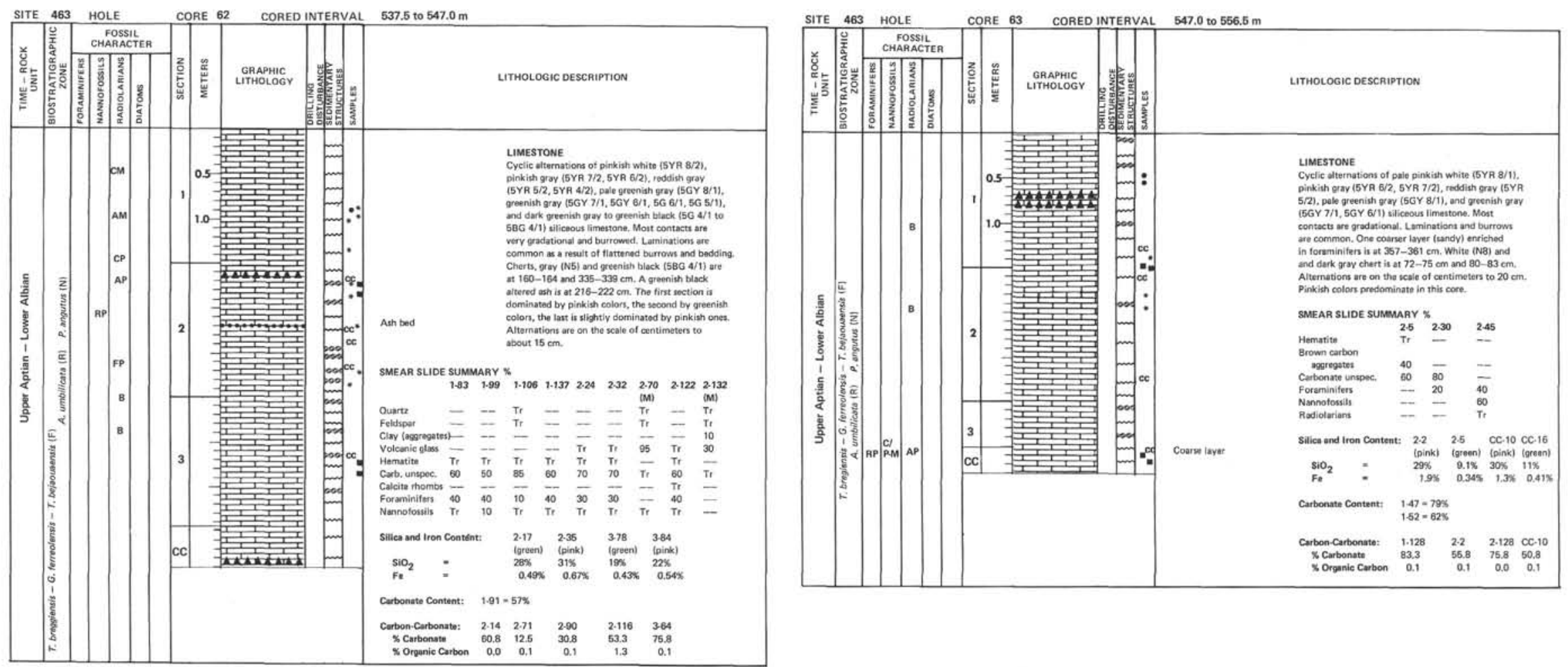

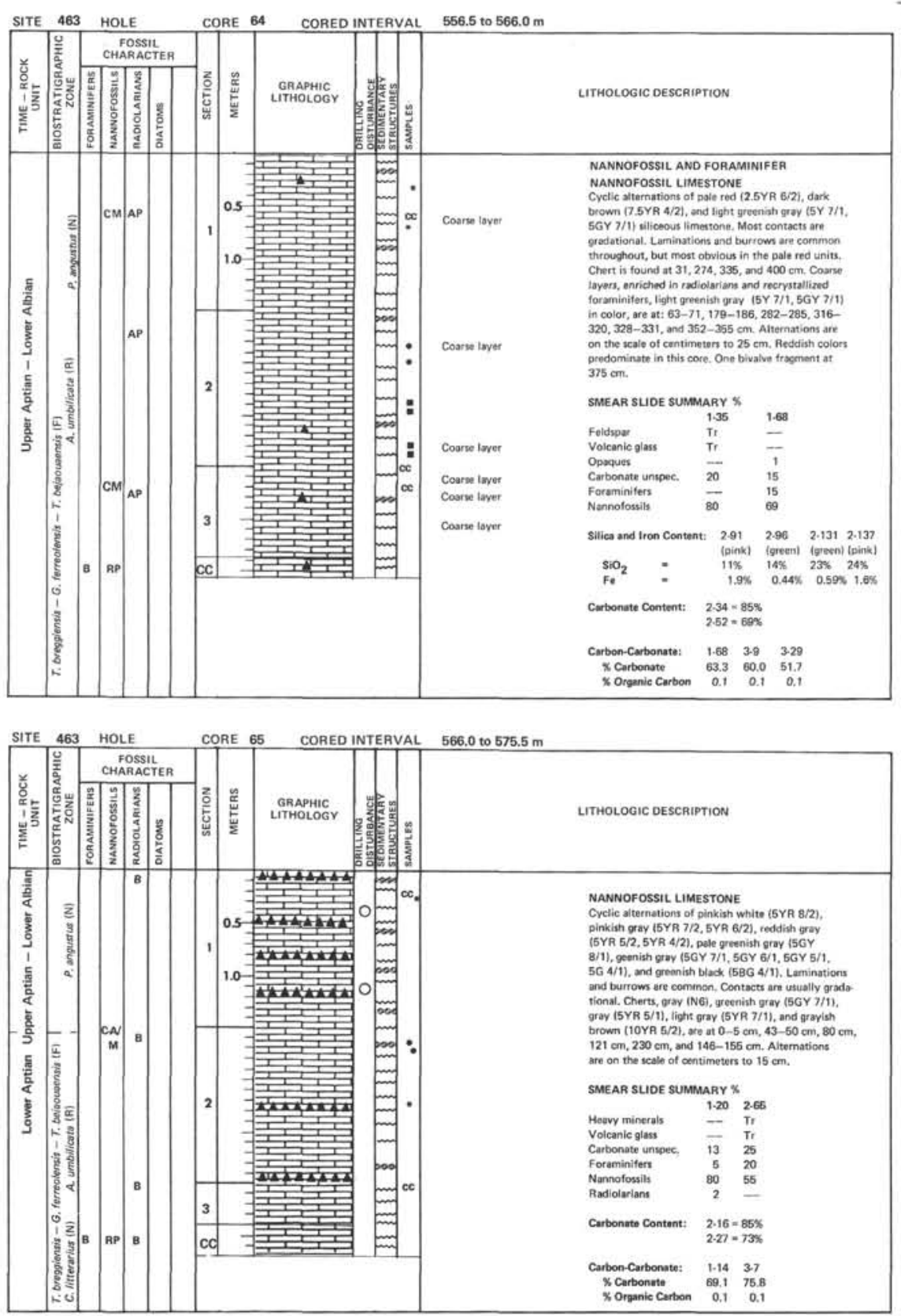
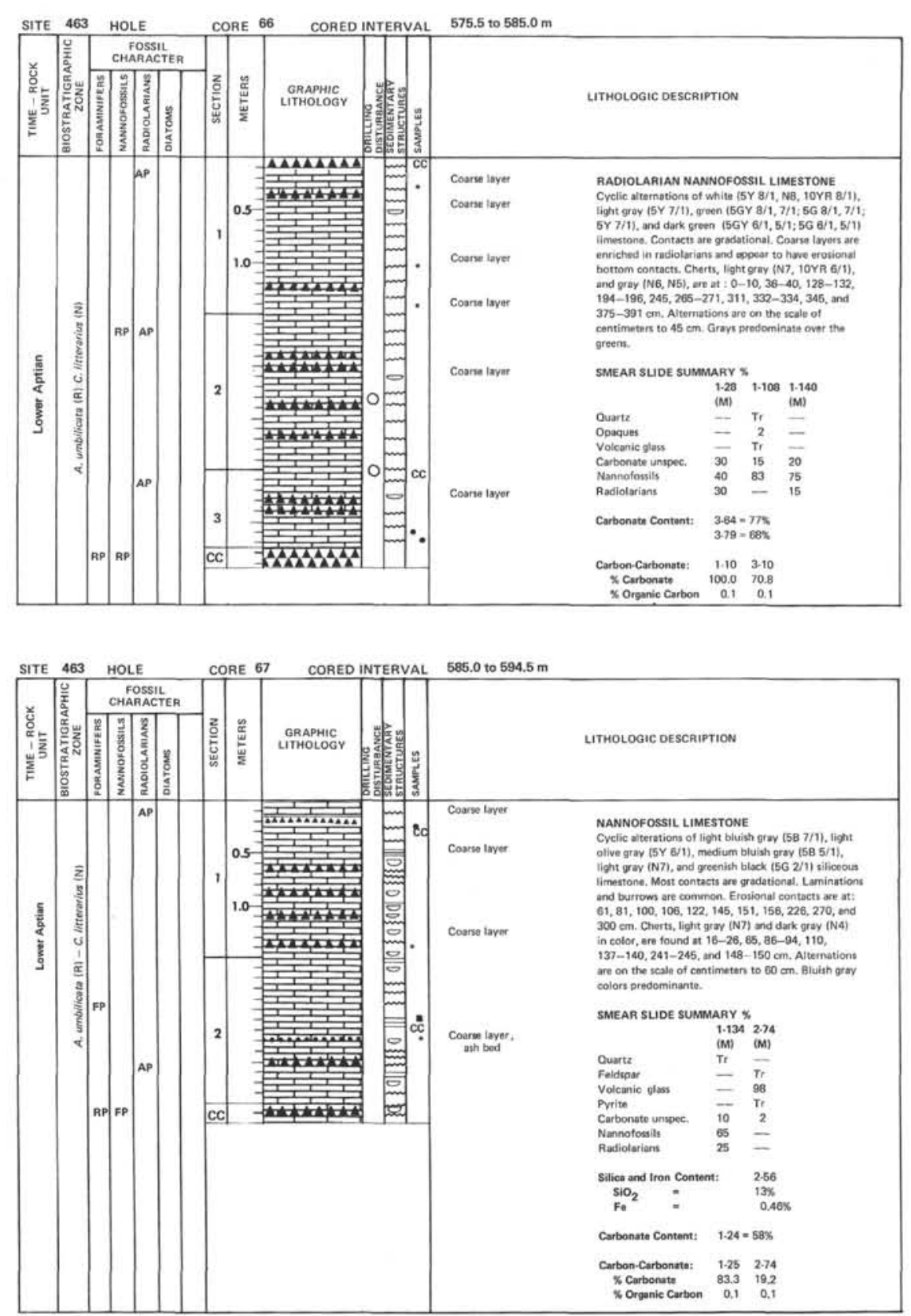

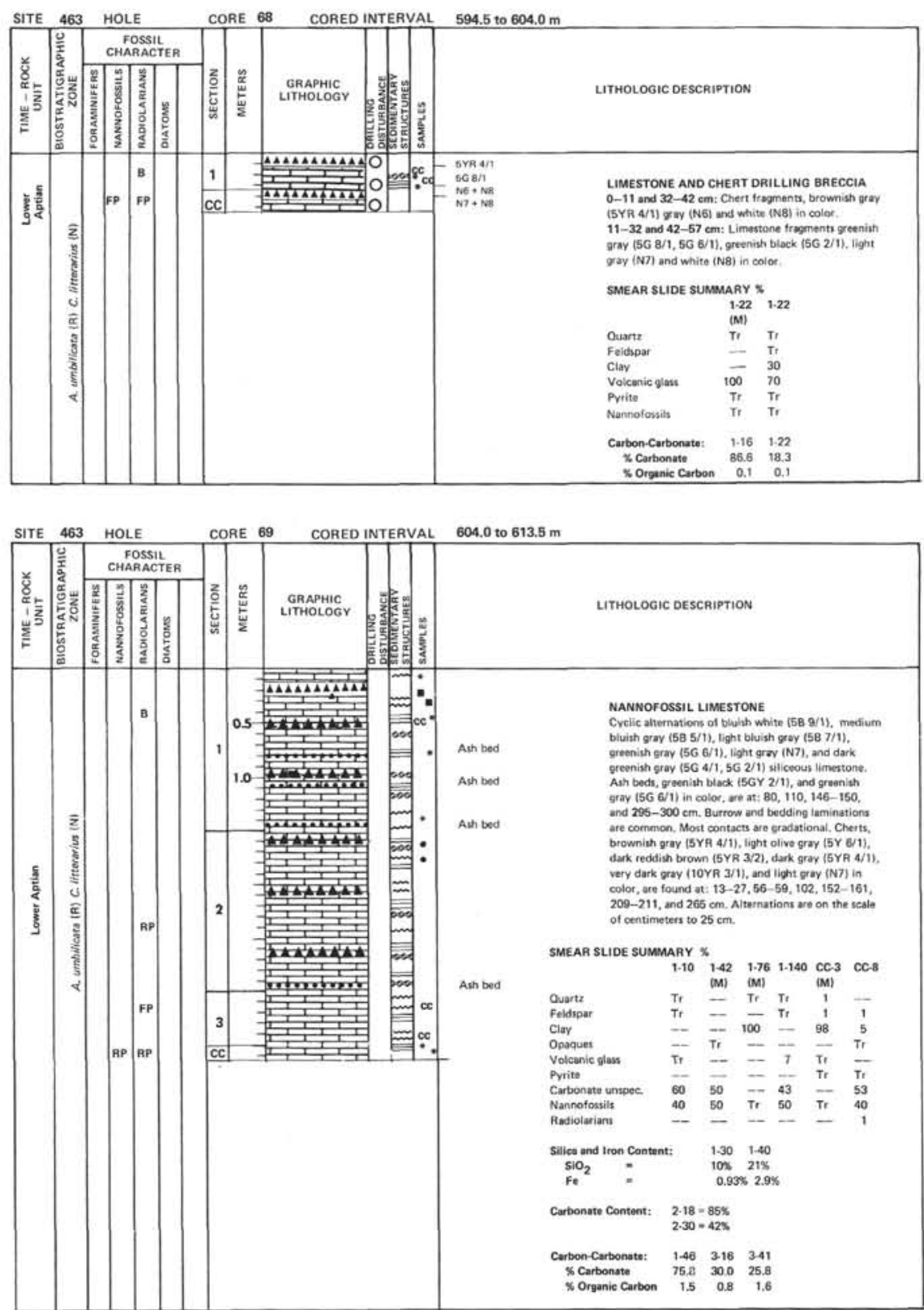

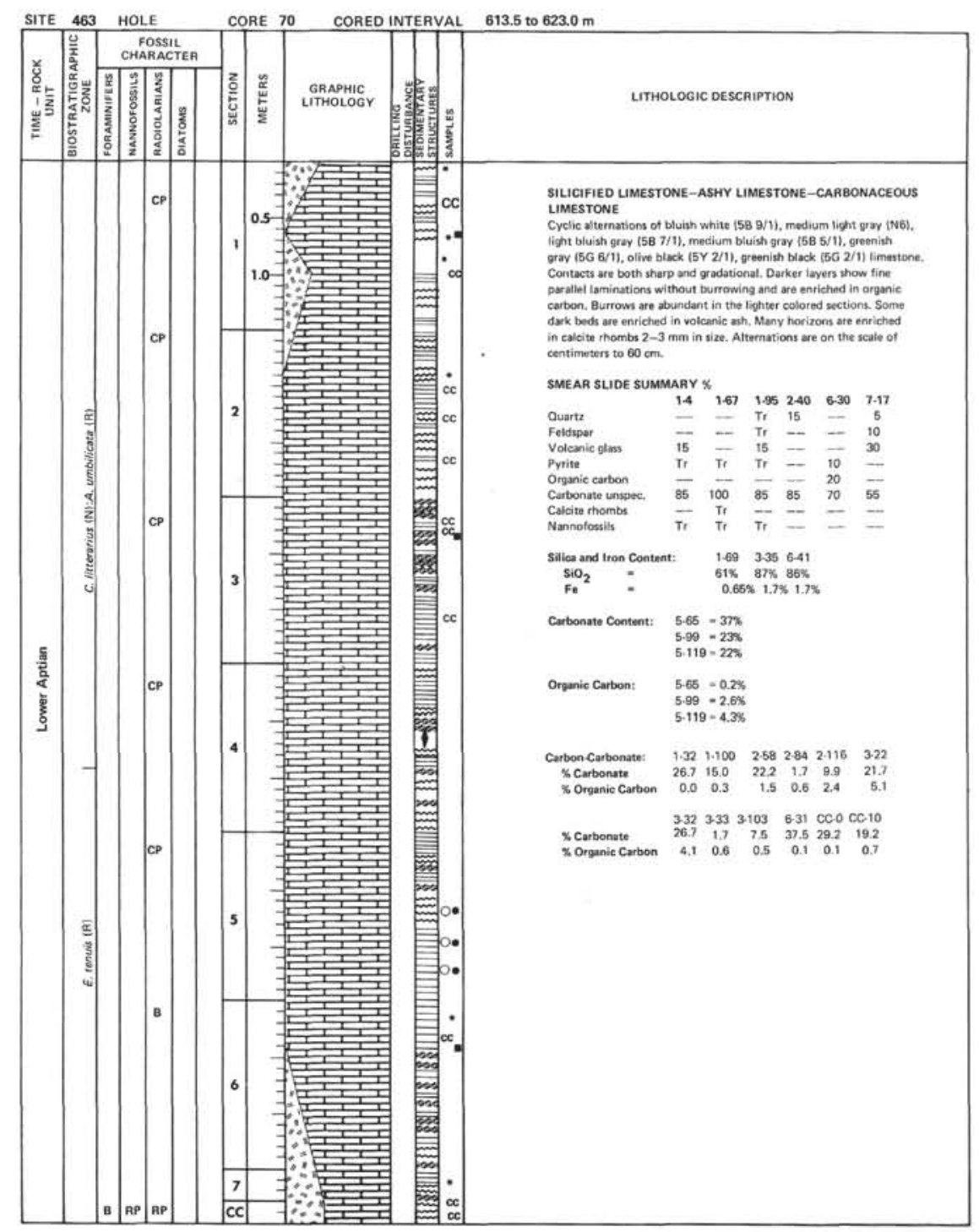



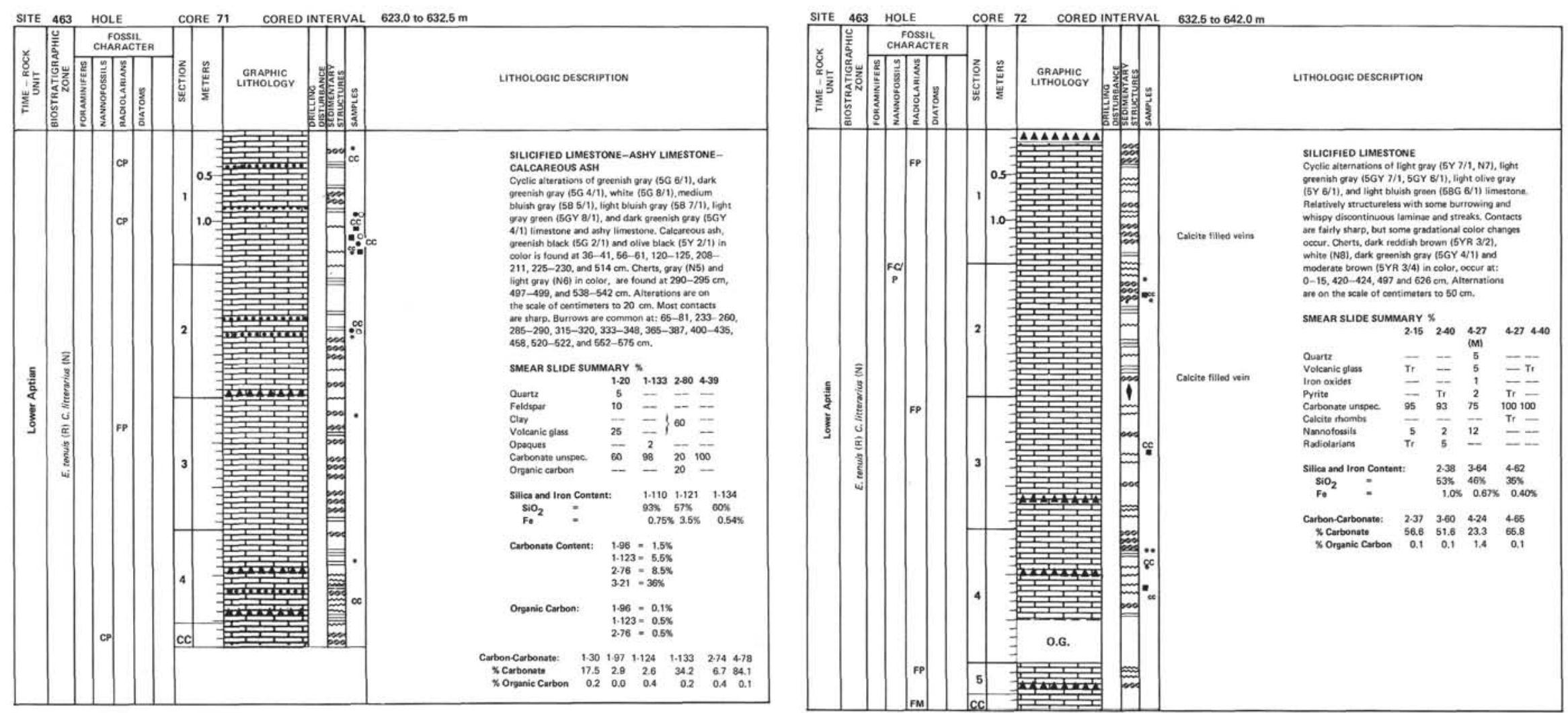


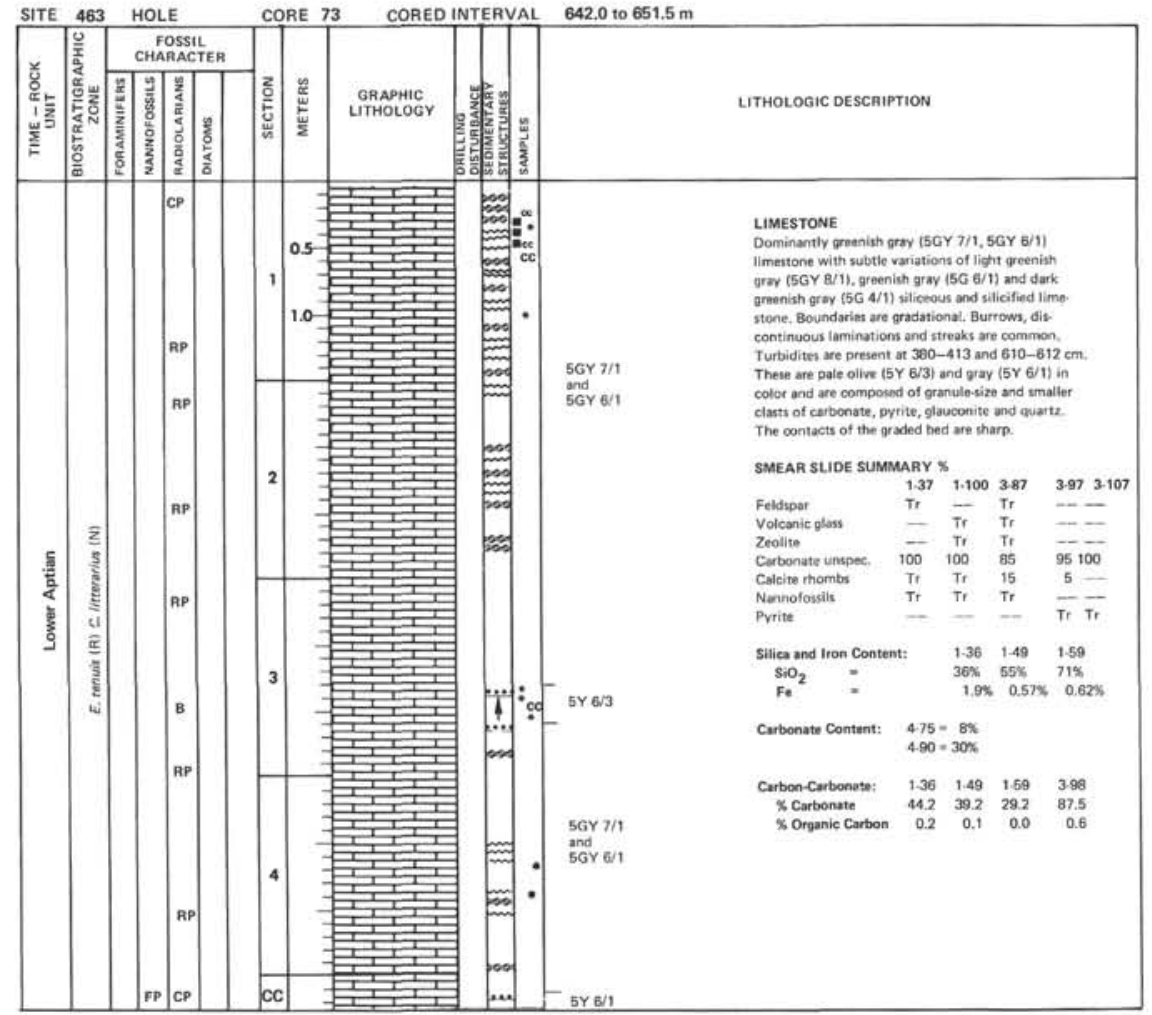

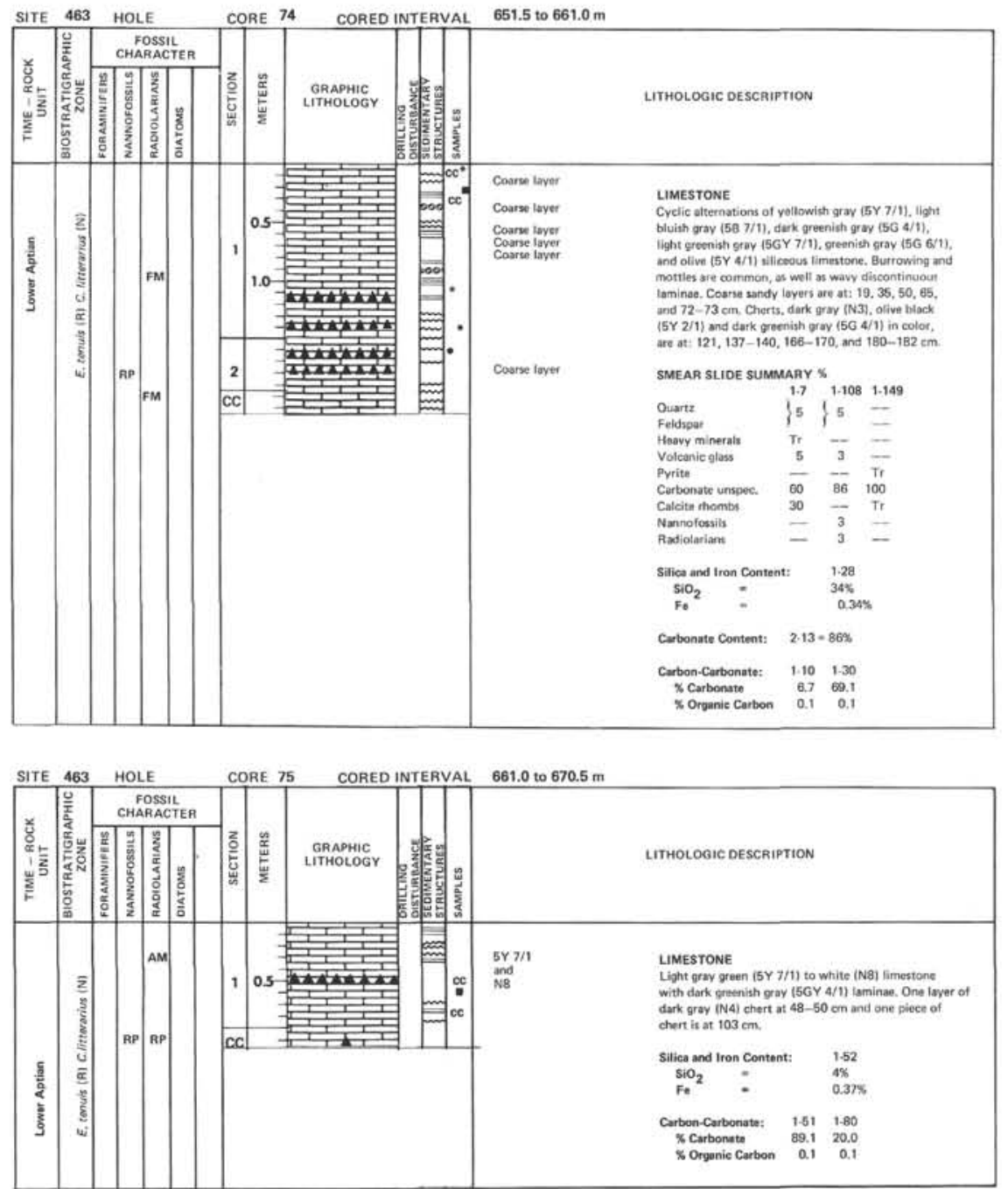



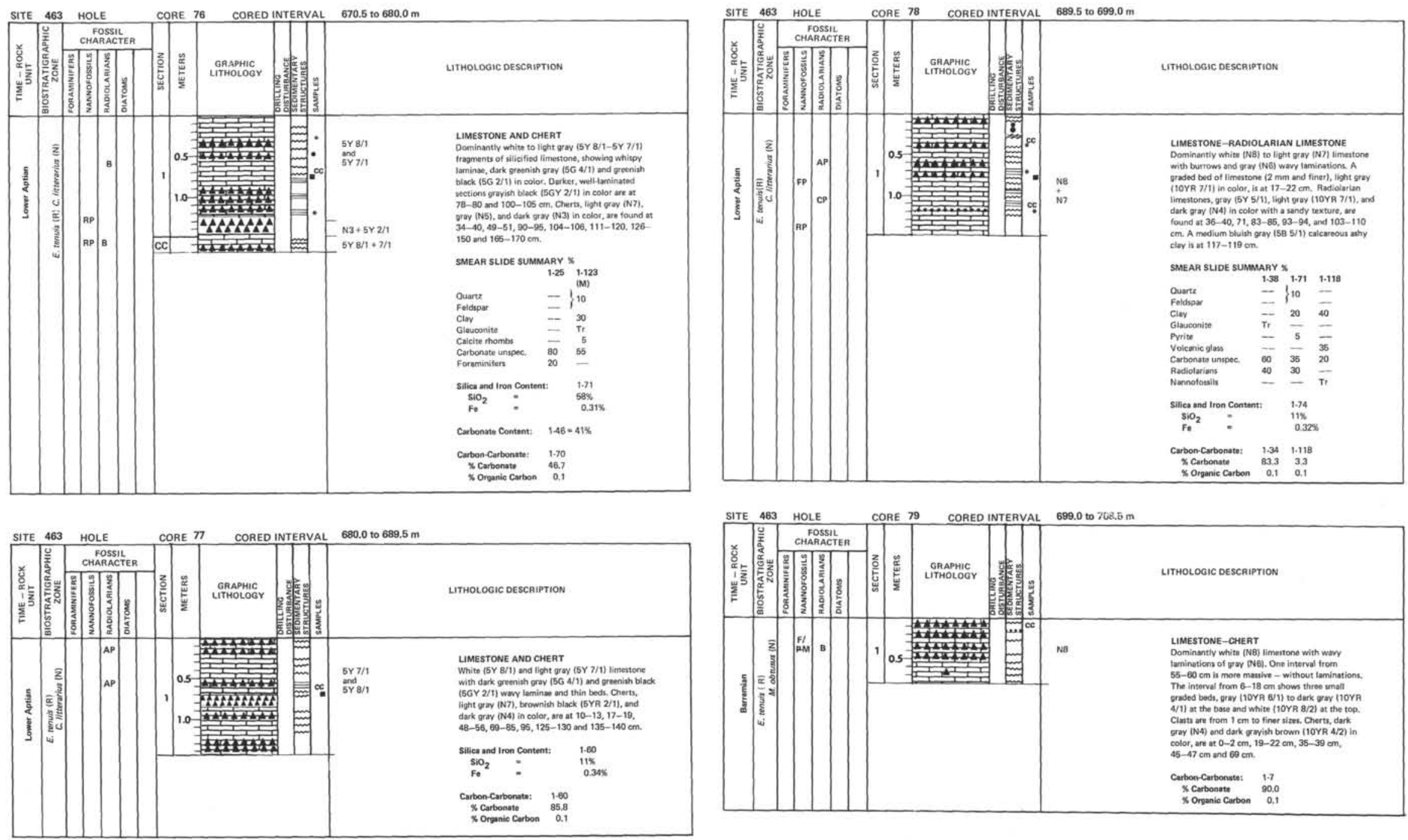

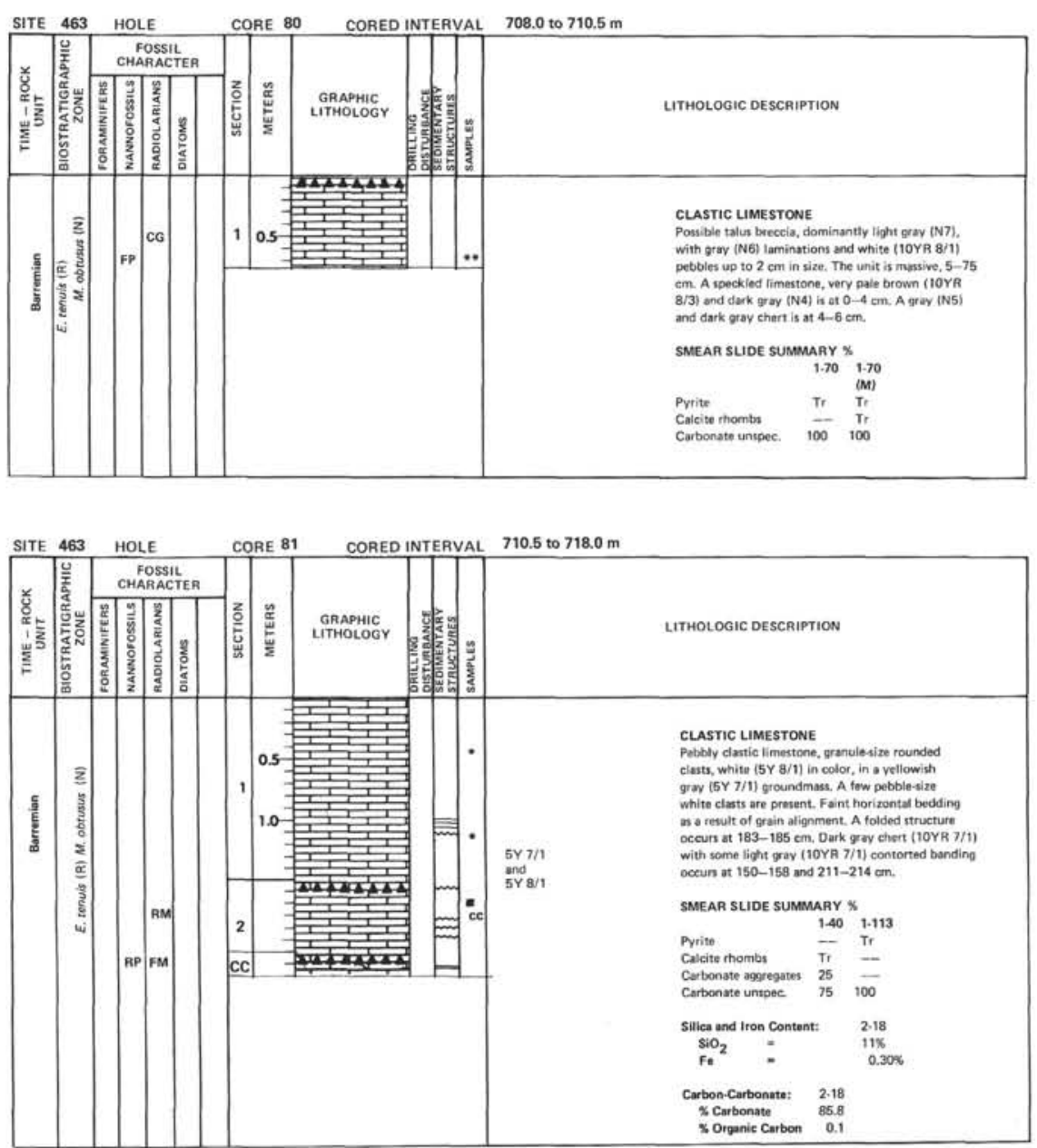

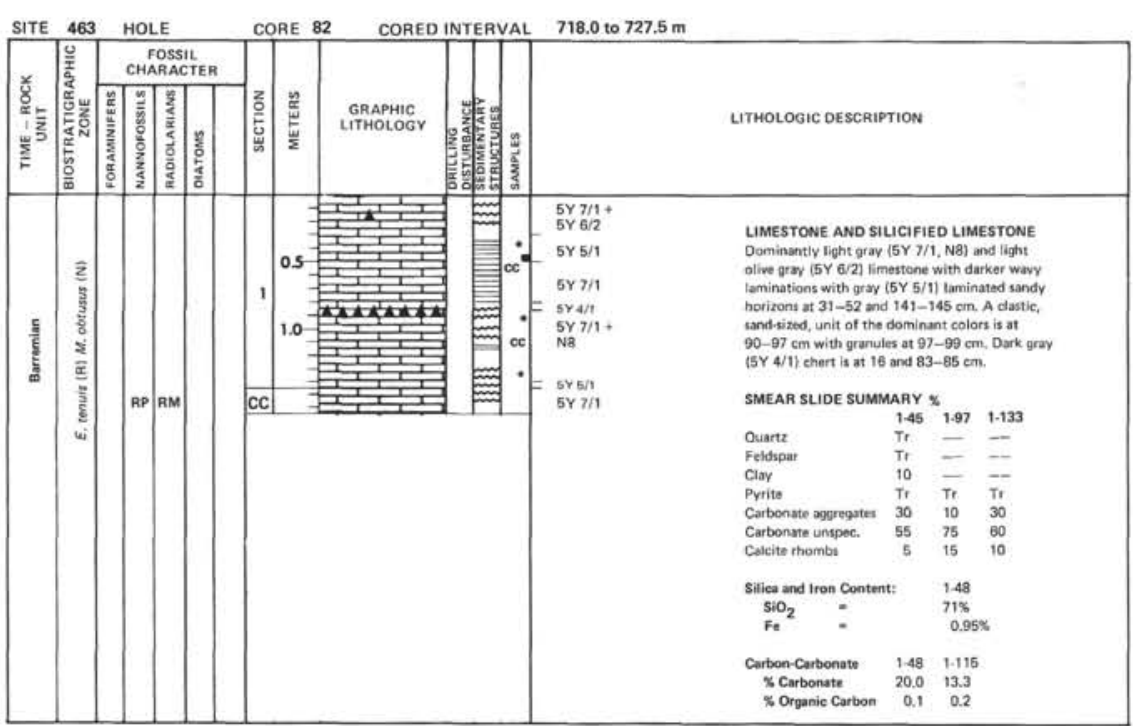

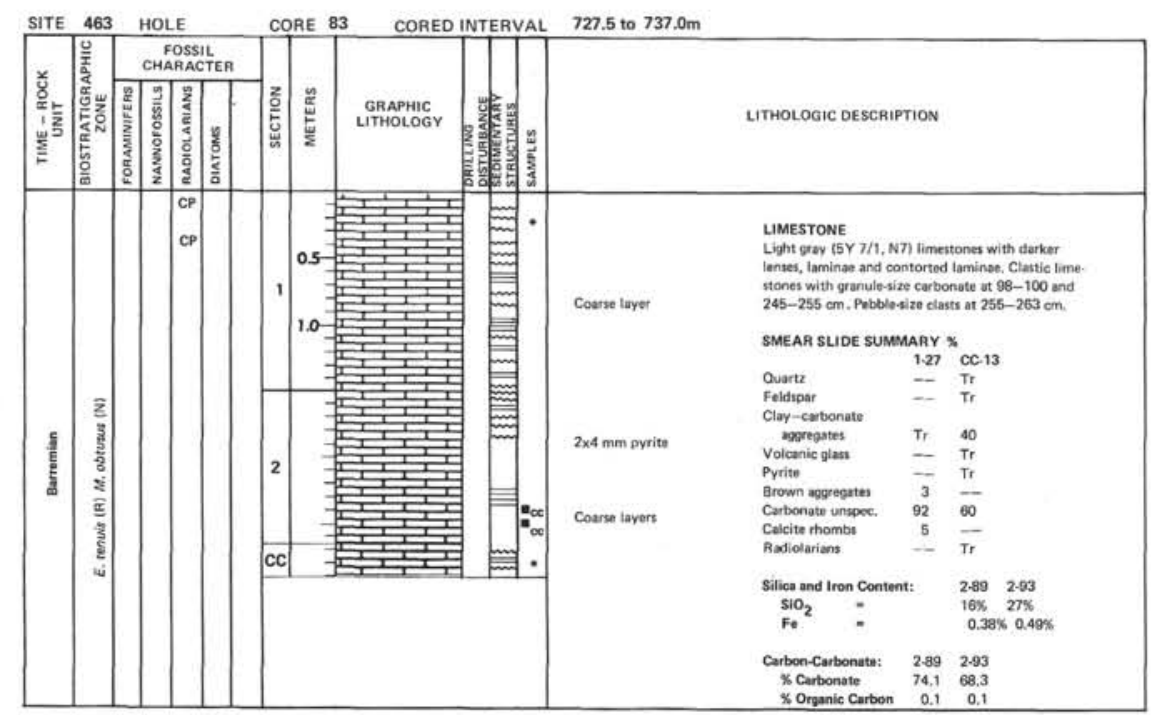



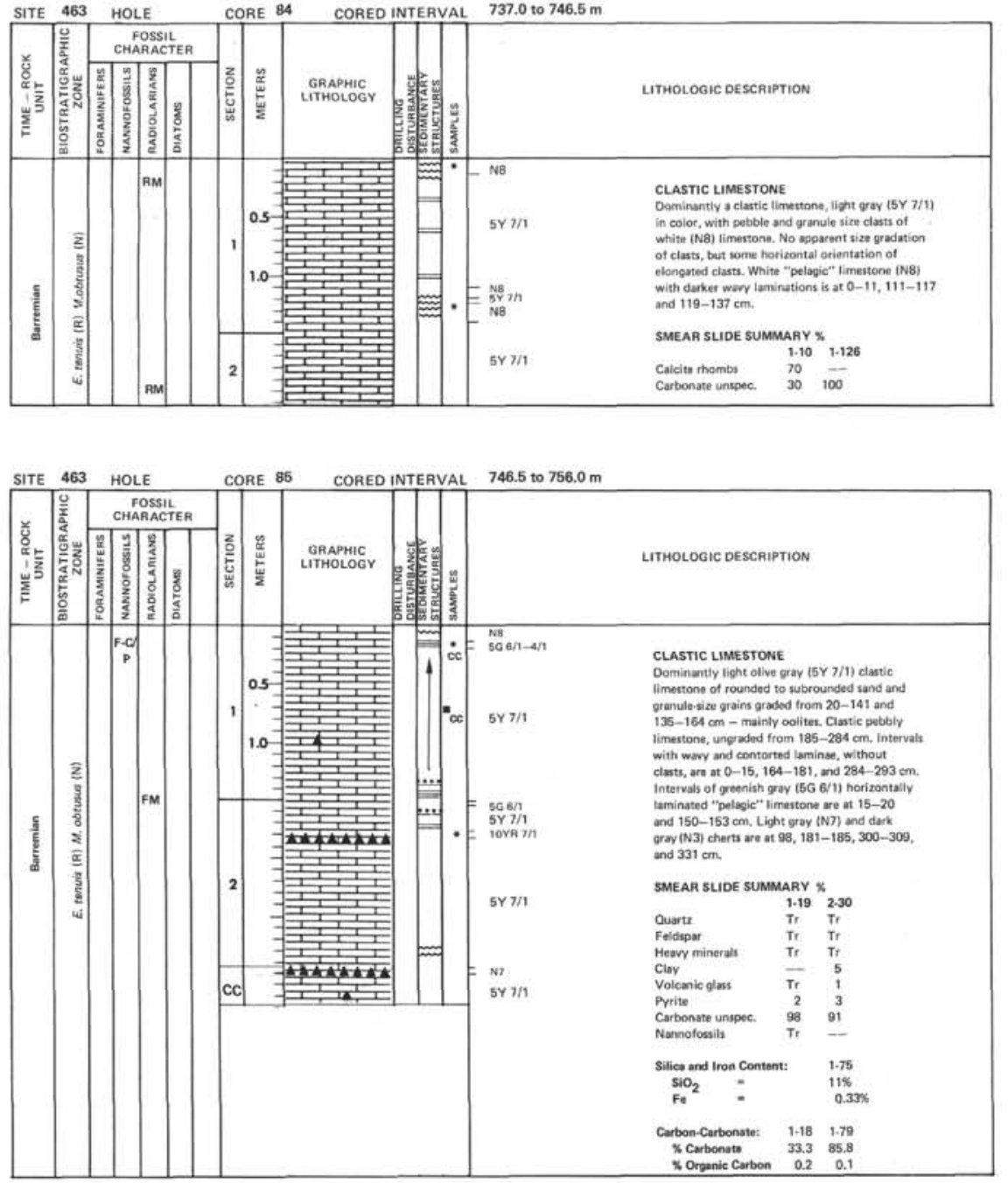
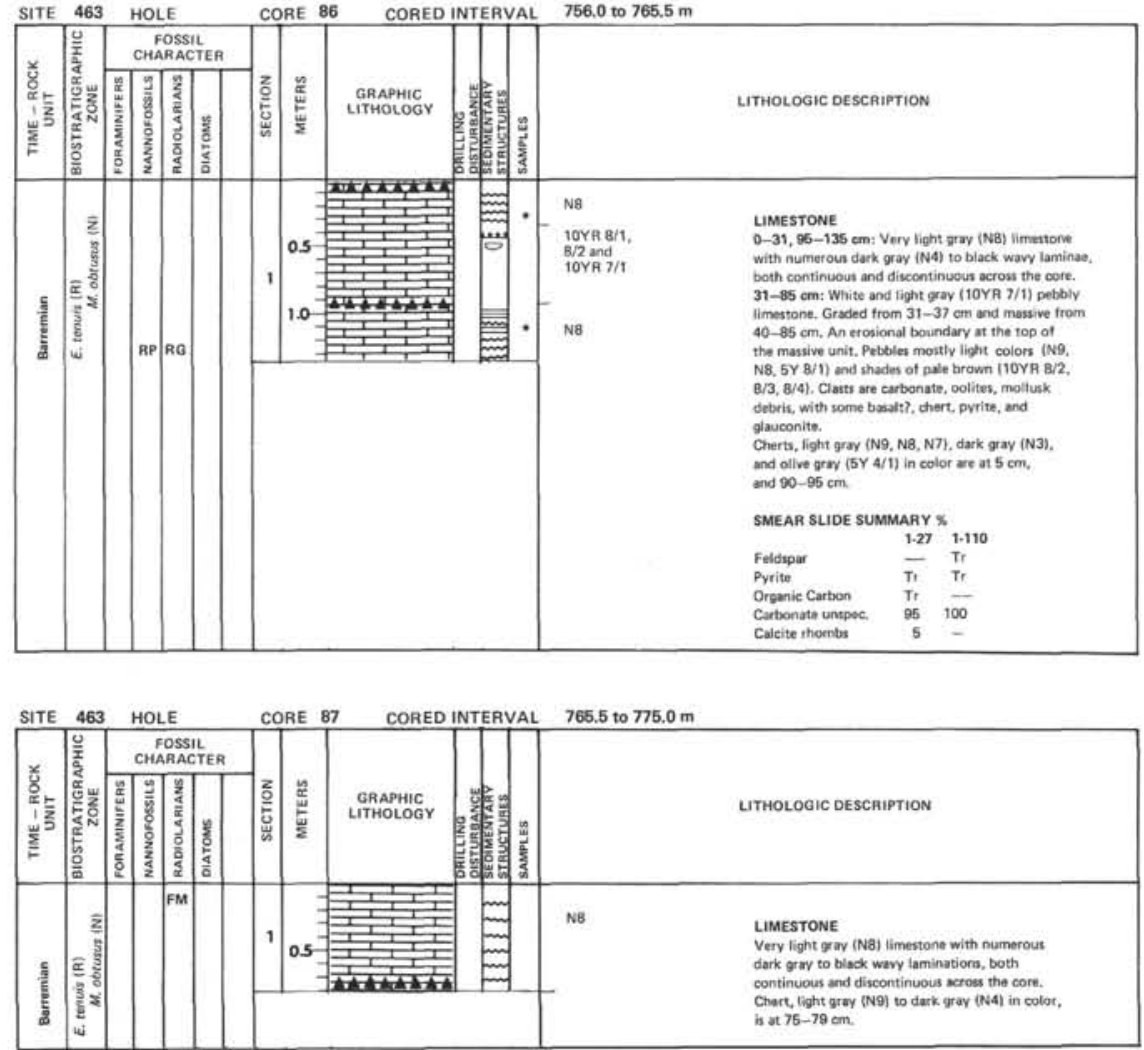

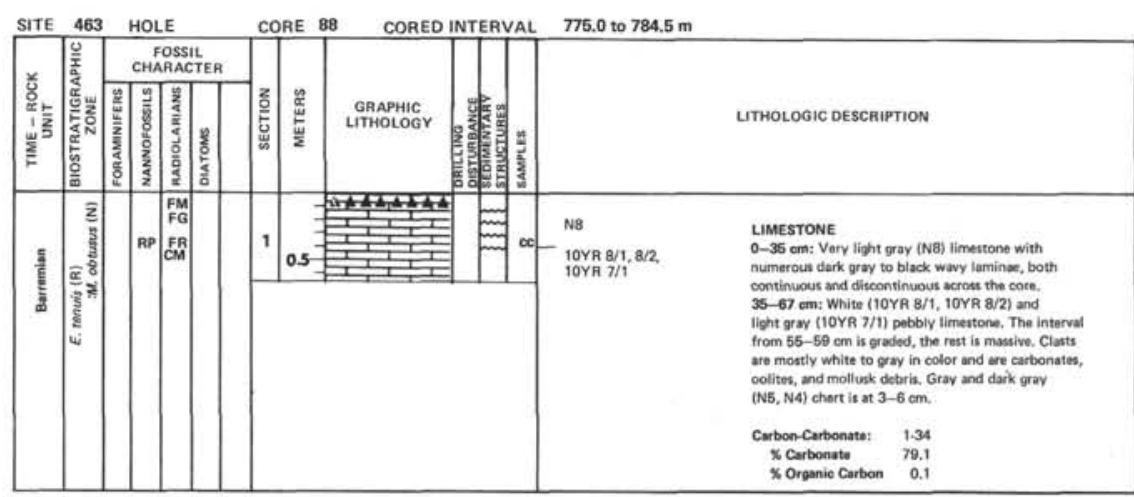



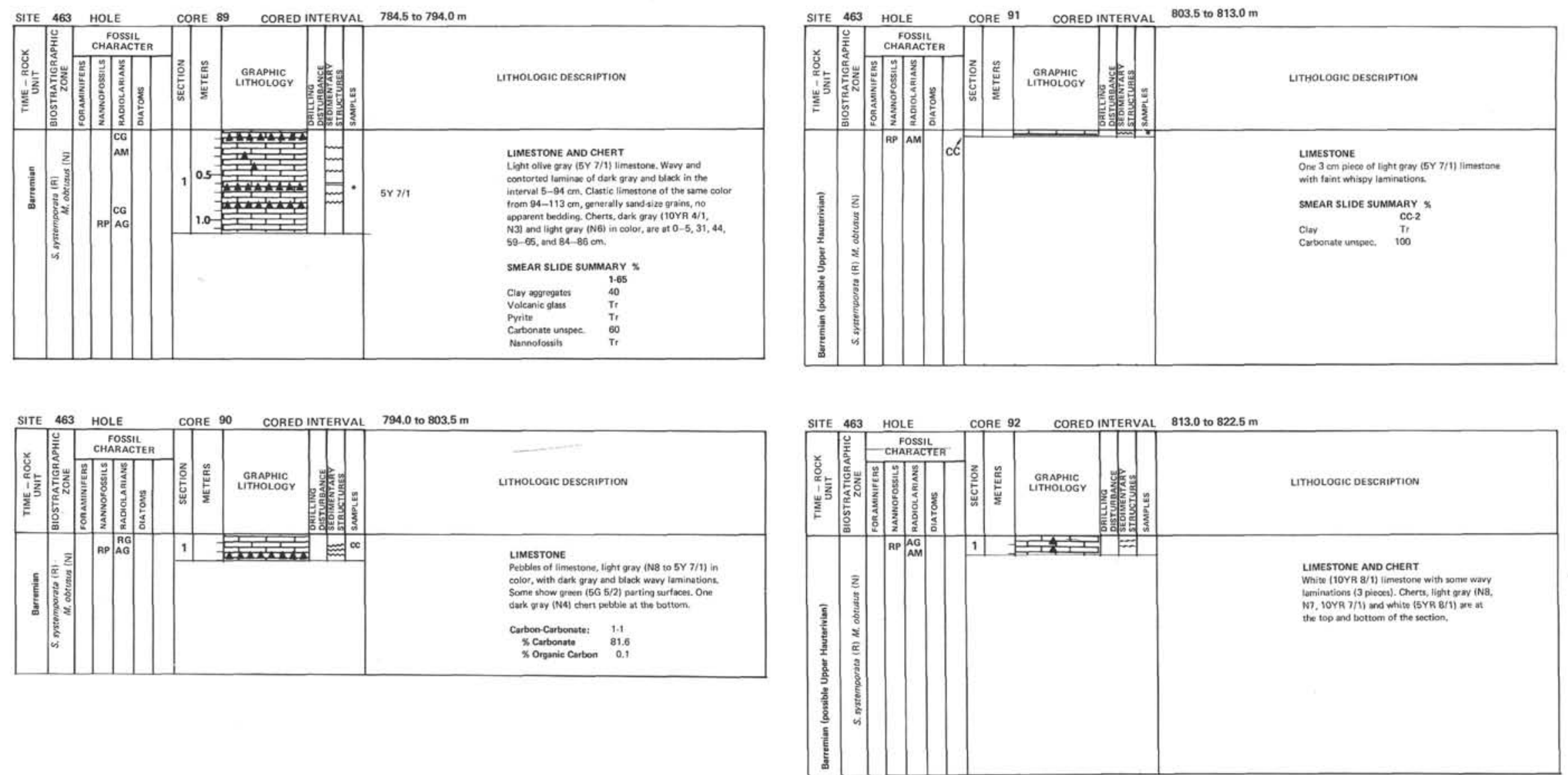


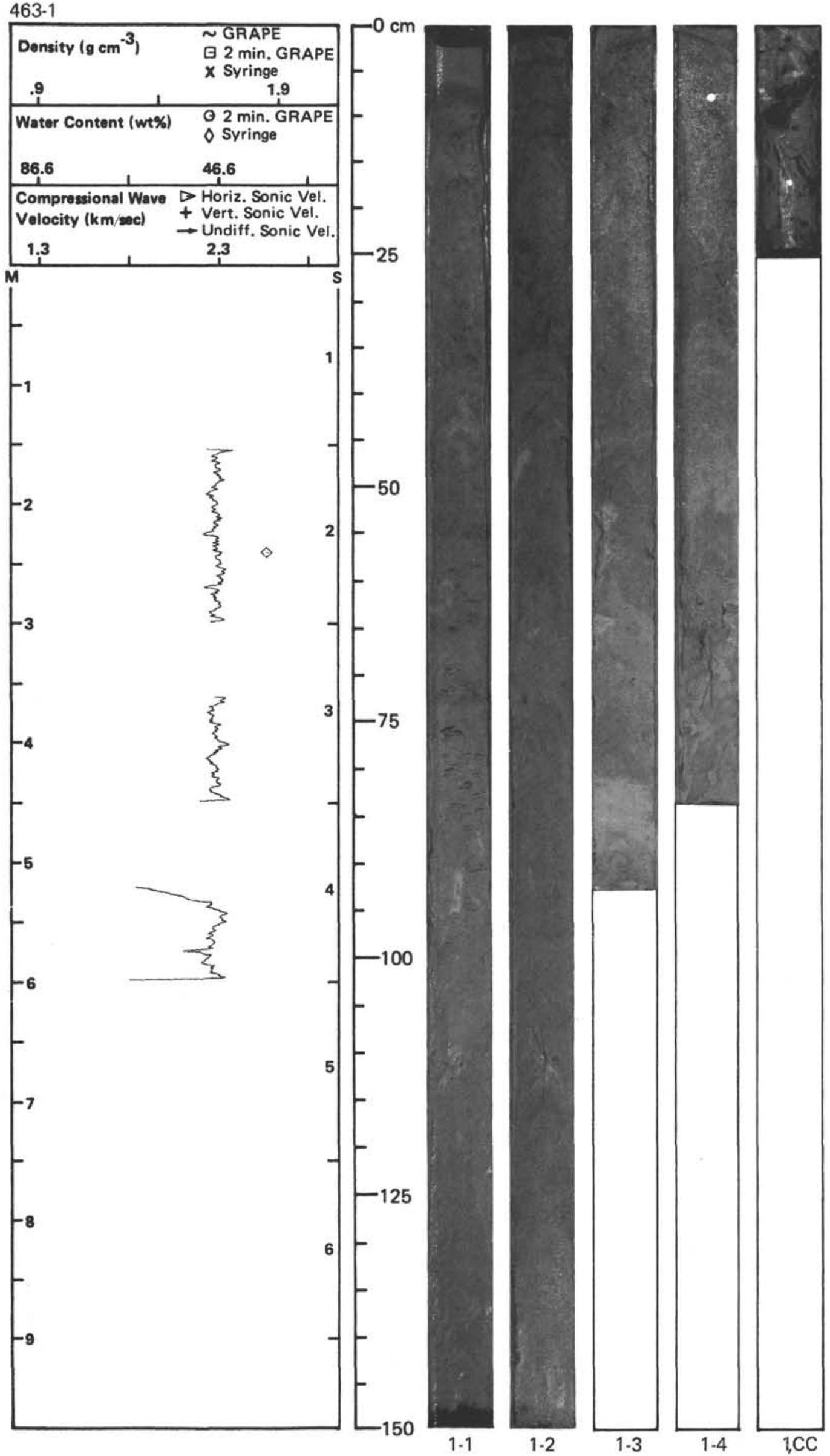




\section{3-2}

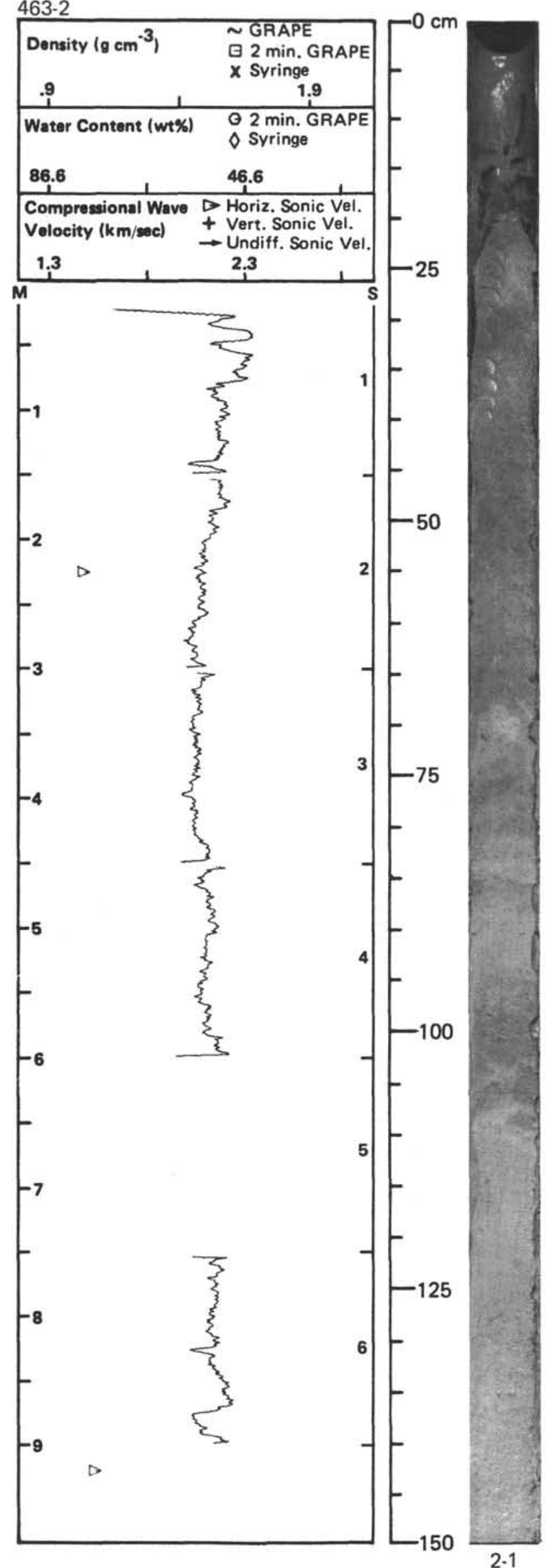

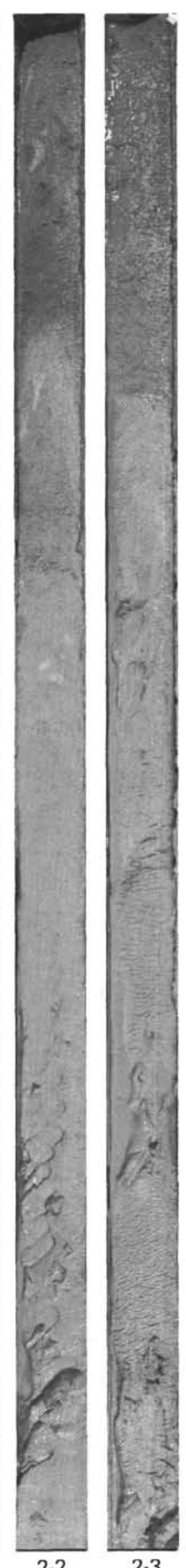

$2-2$
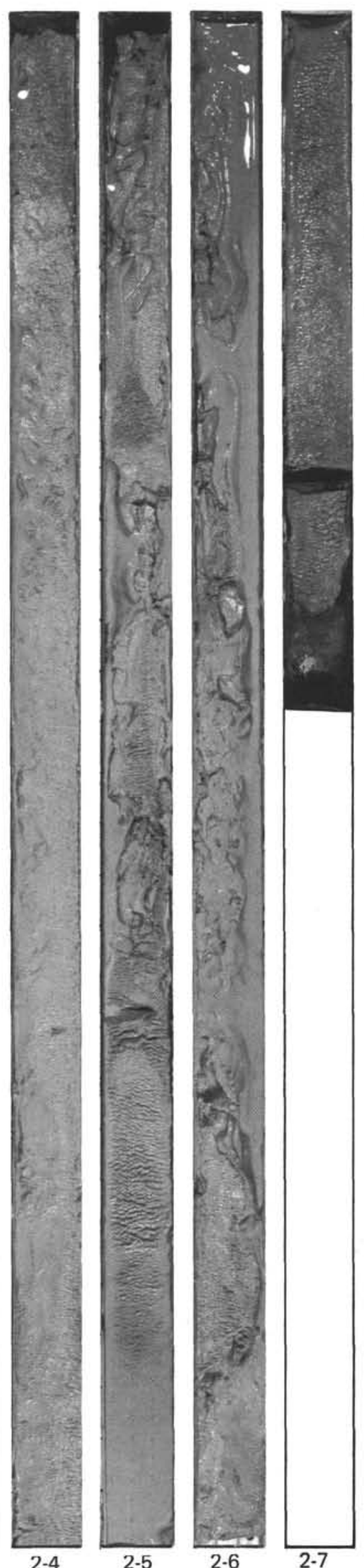


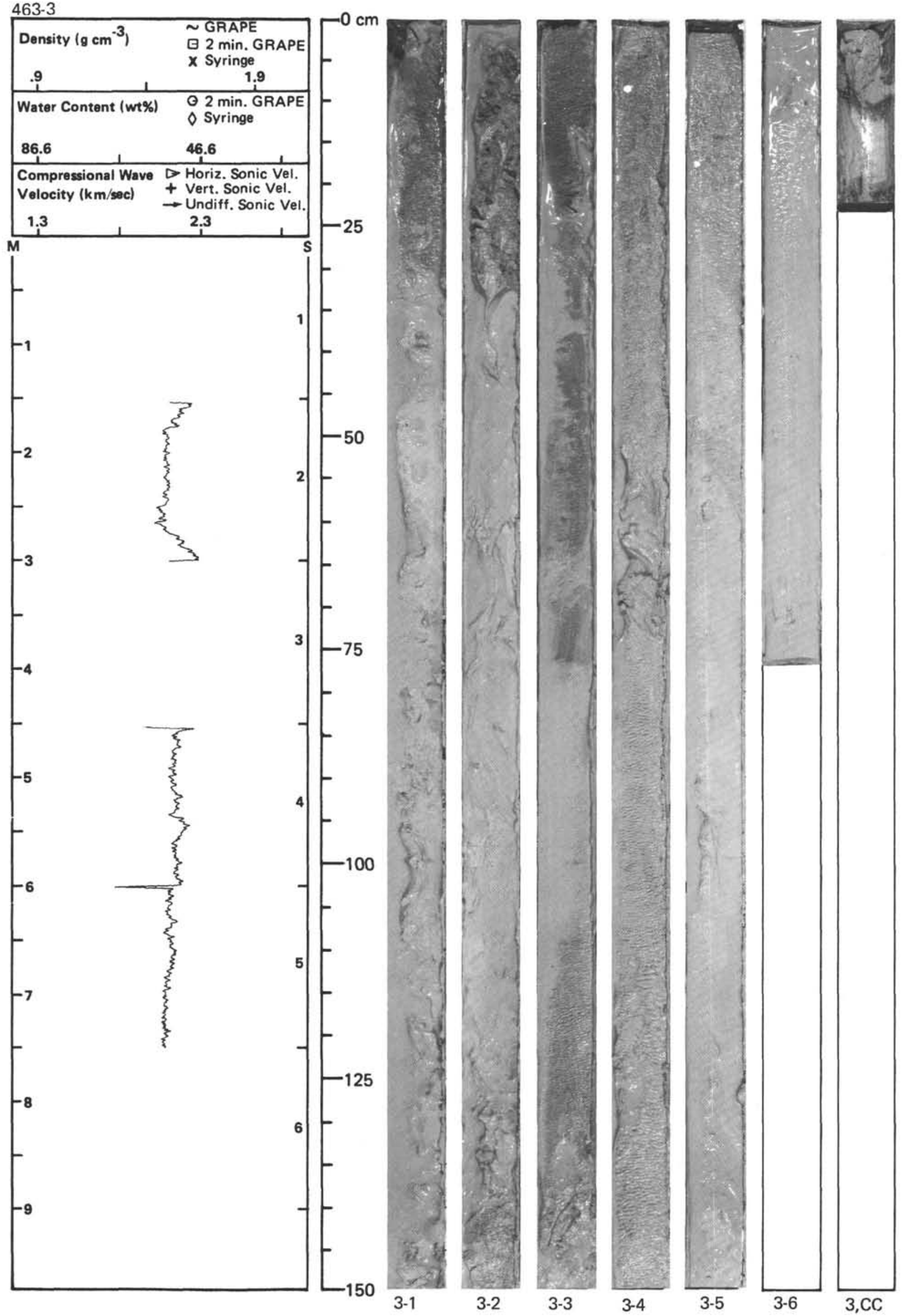




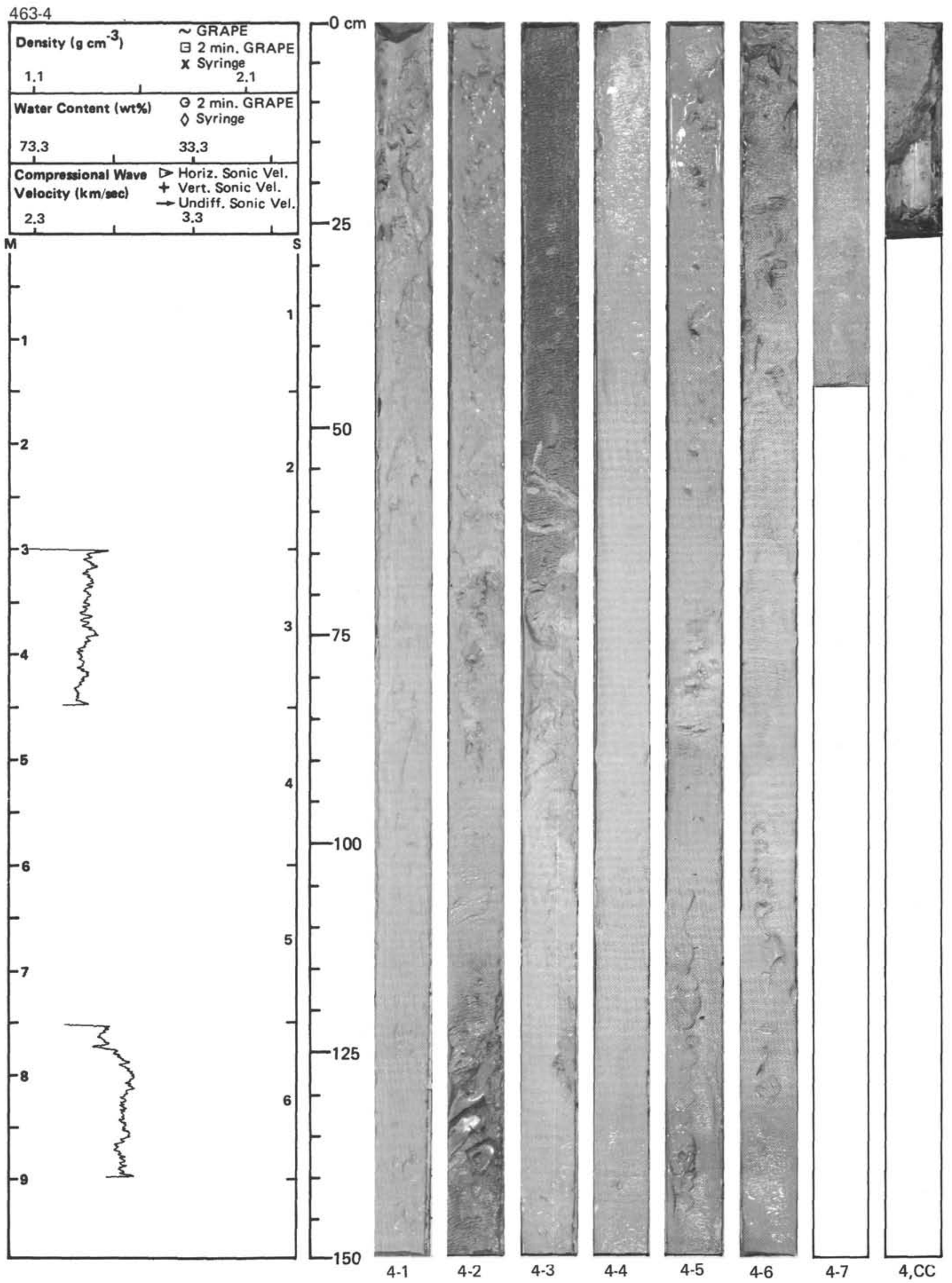




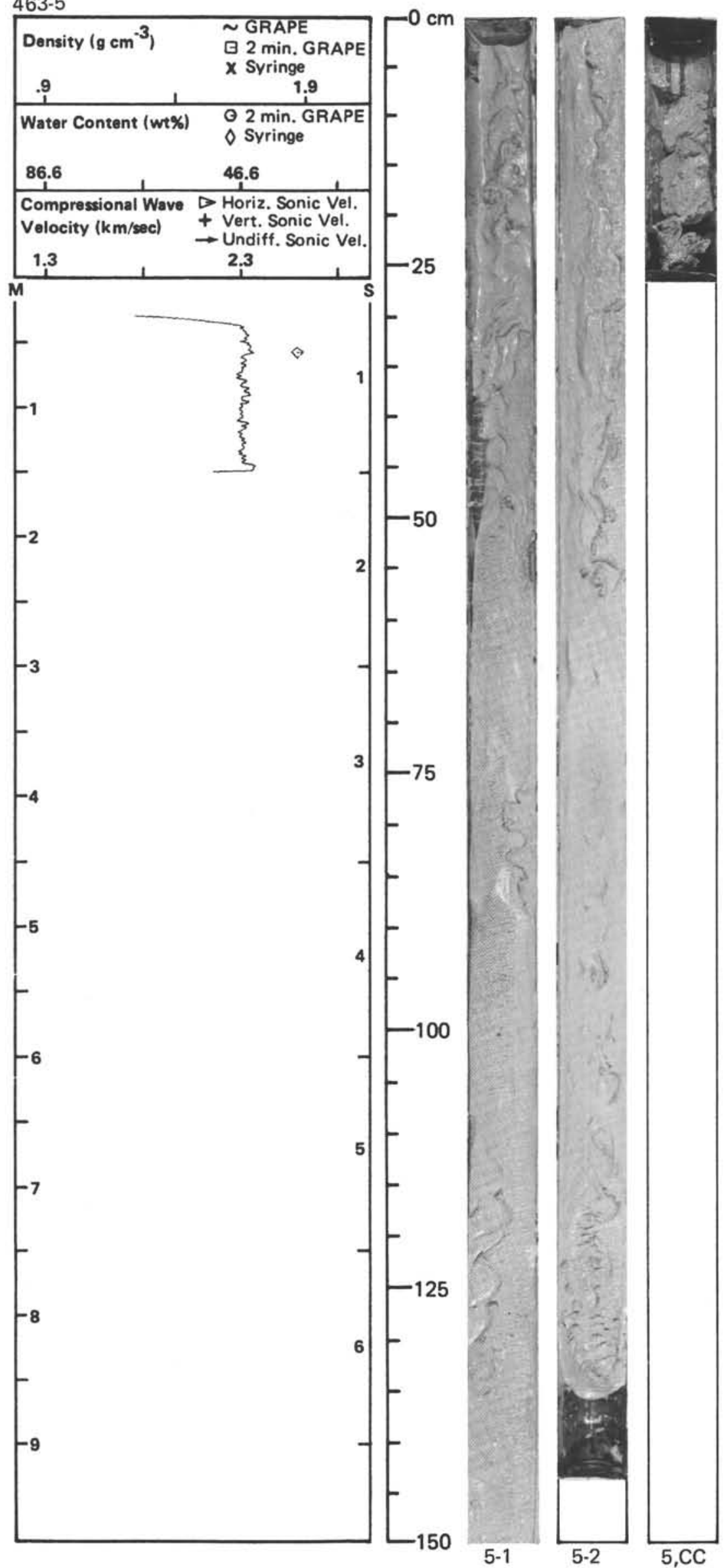




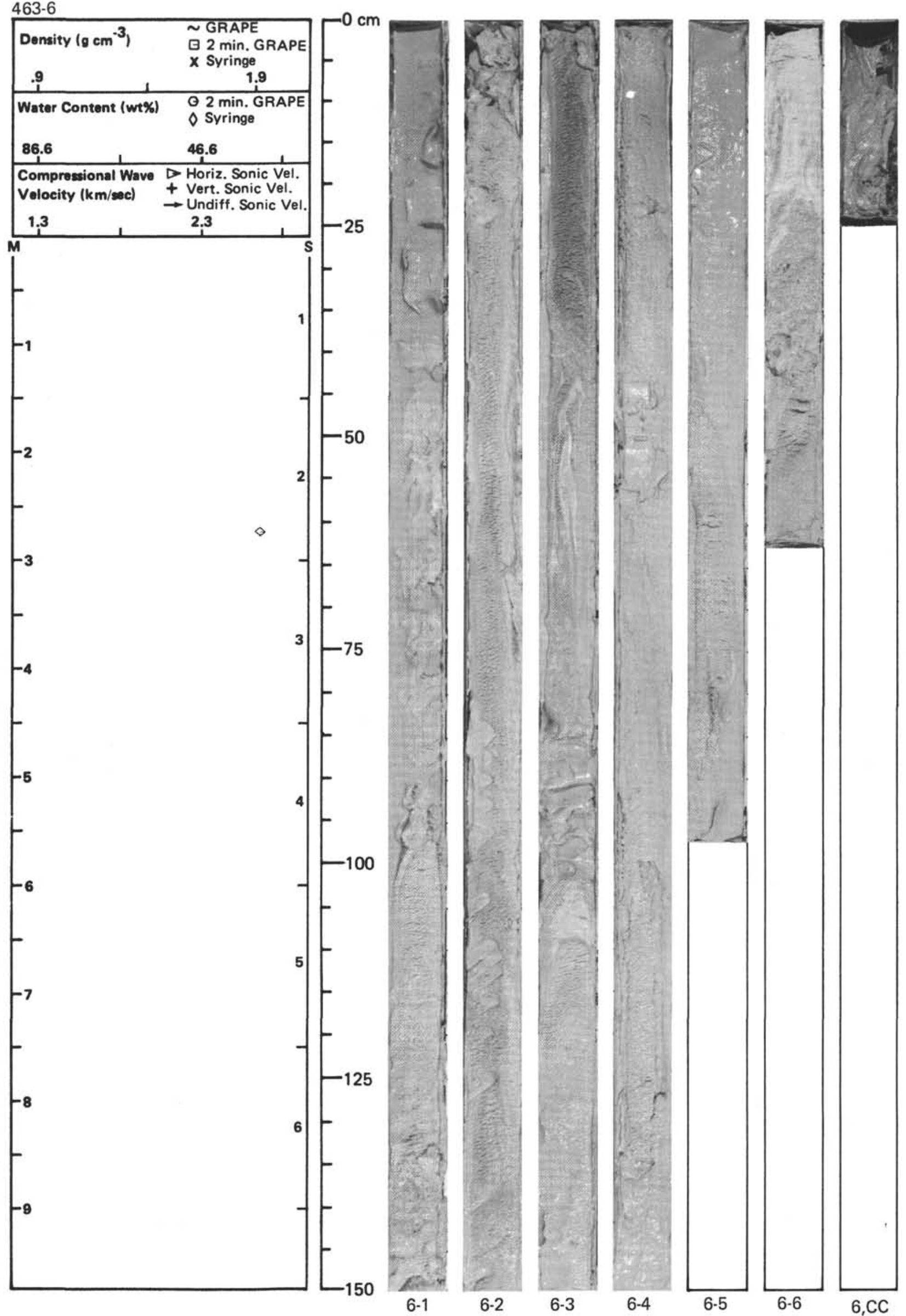




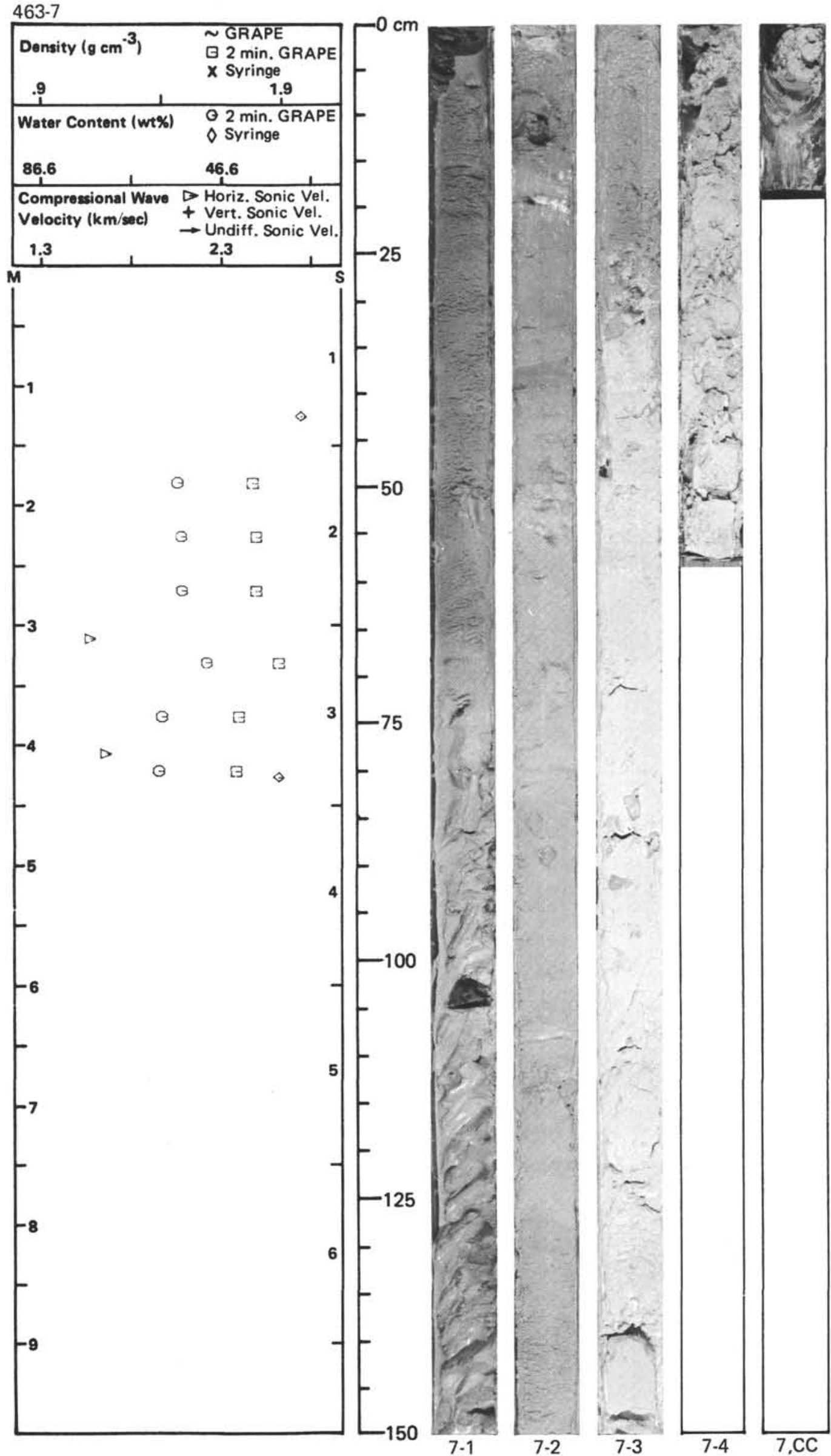




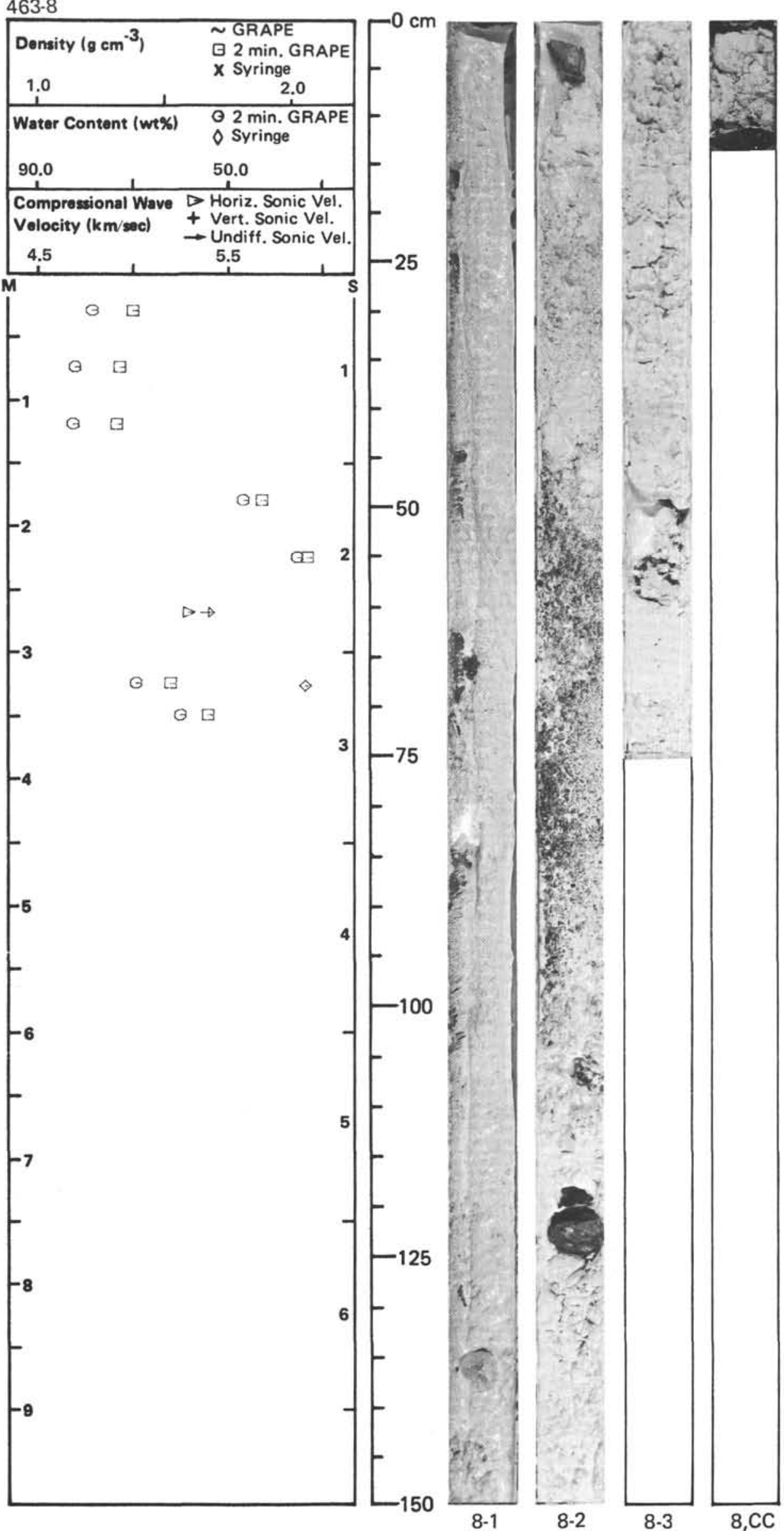




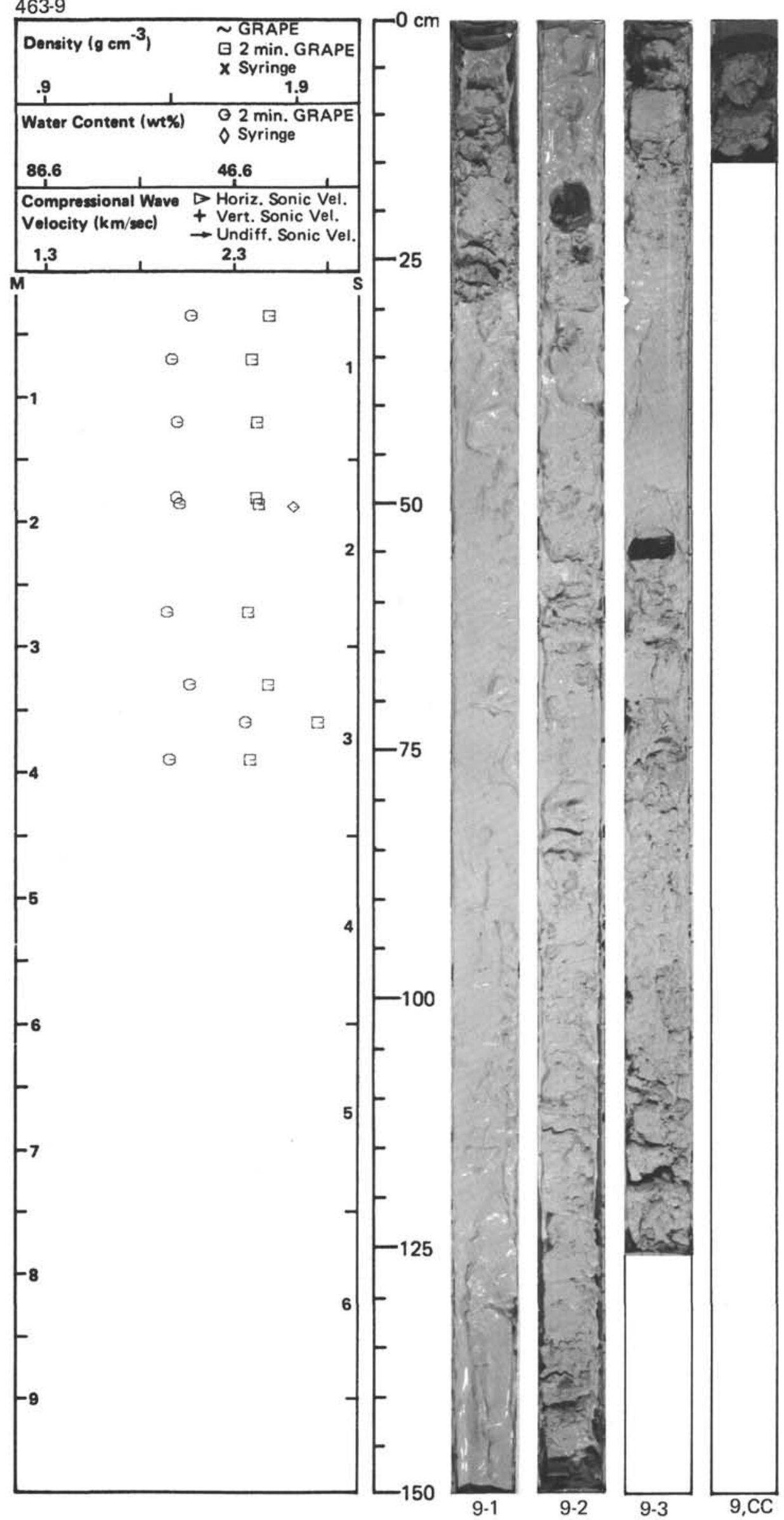


463-10

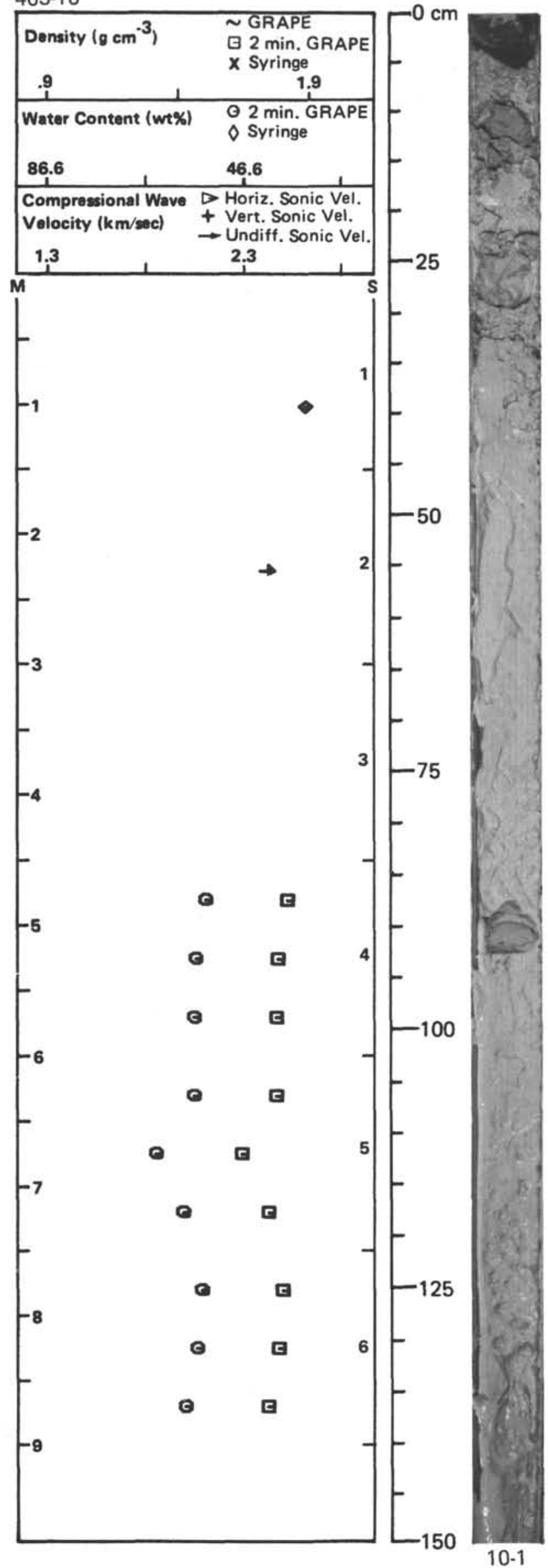

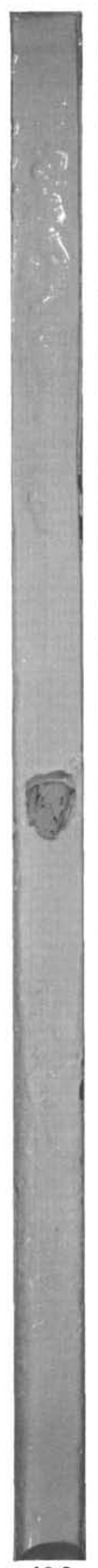

10-2
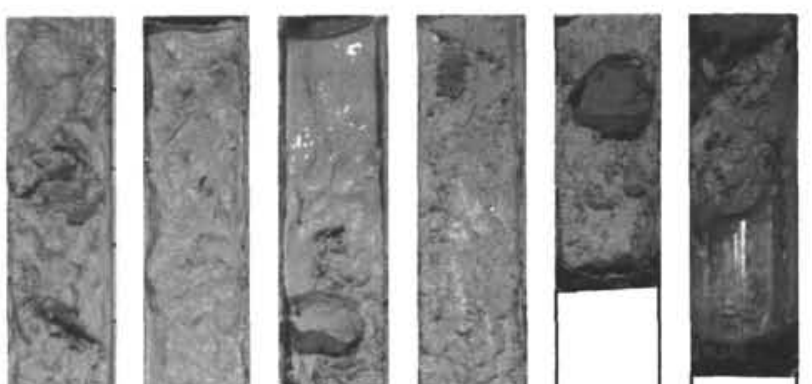

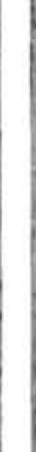

\section{.}
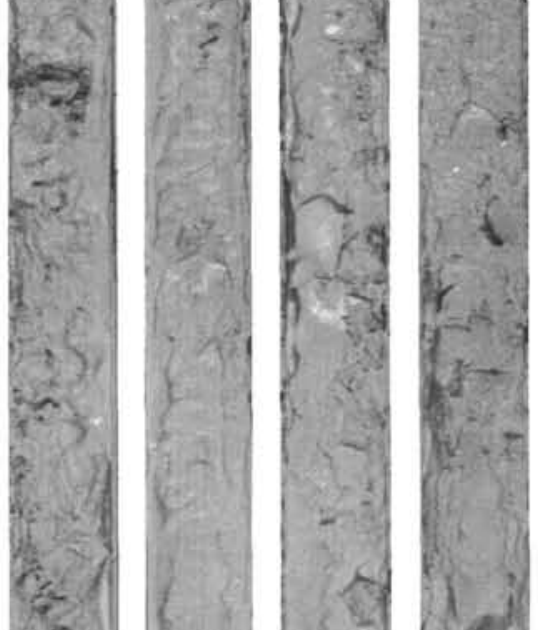

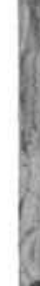
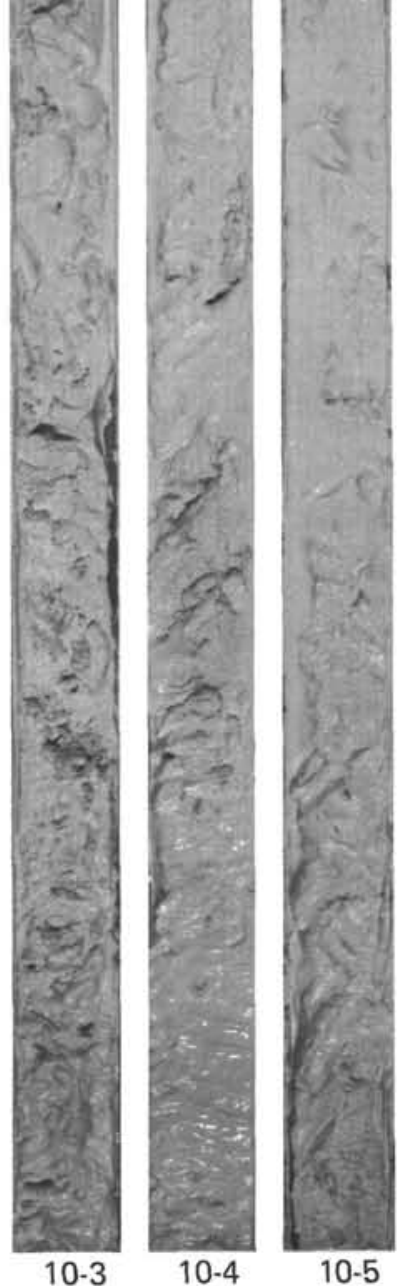

$10-5$

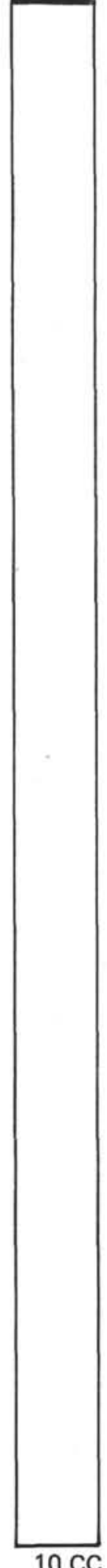


463-11

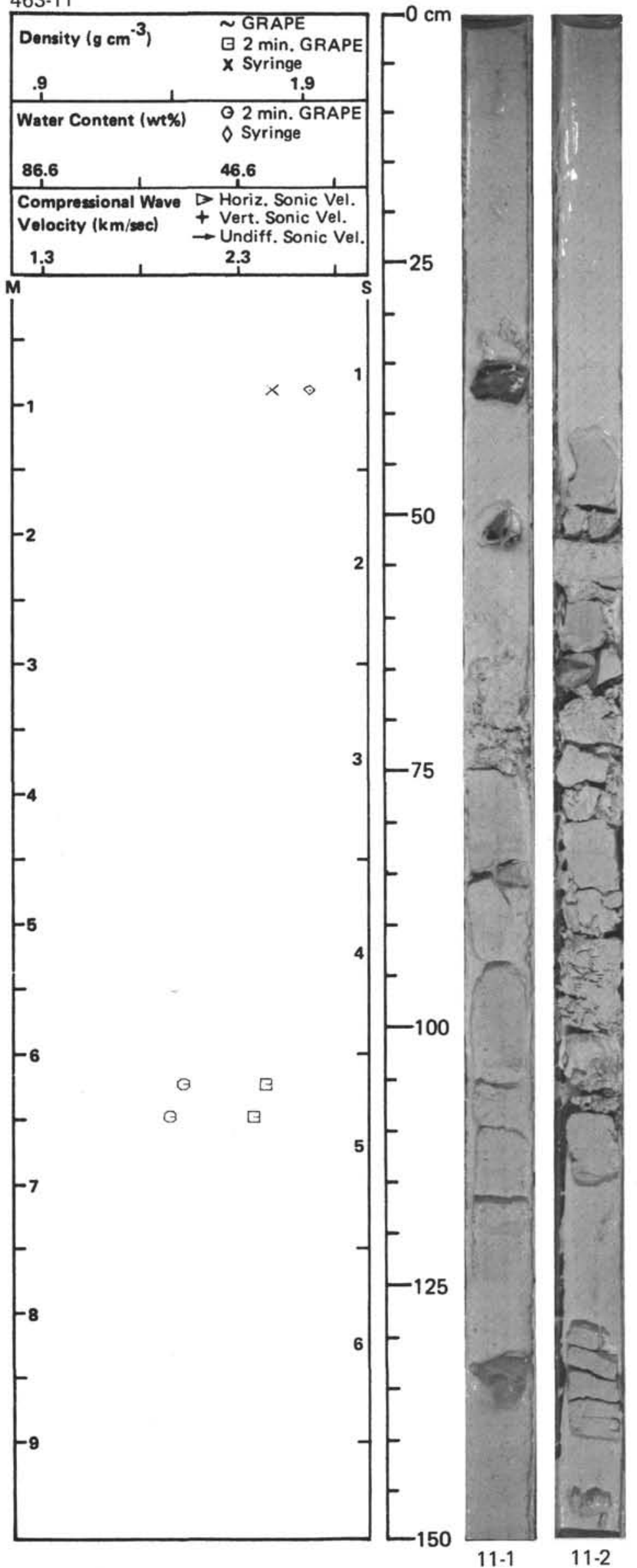

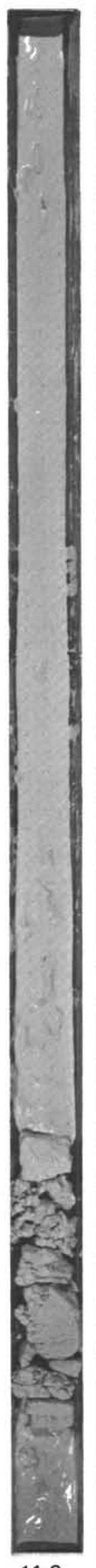

11-3
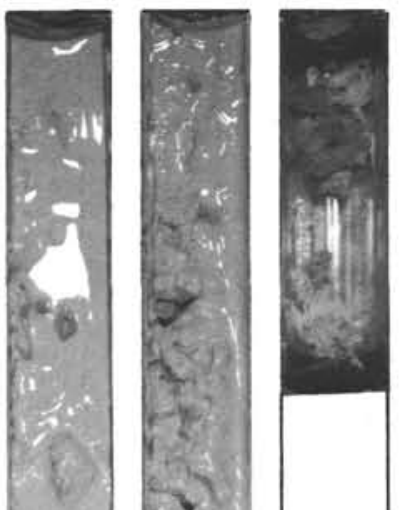
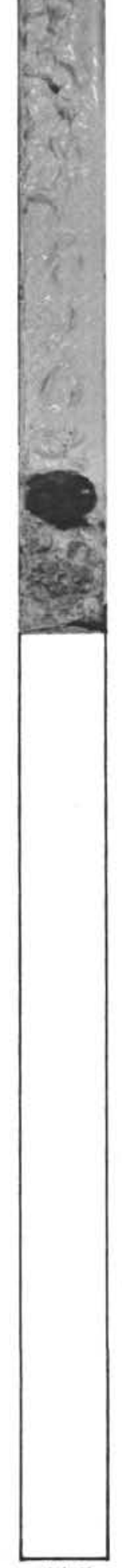

$11-4$

11-5

$11, \mathrm{CC}$ 


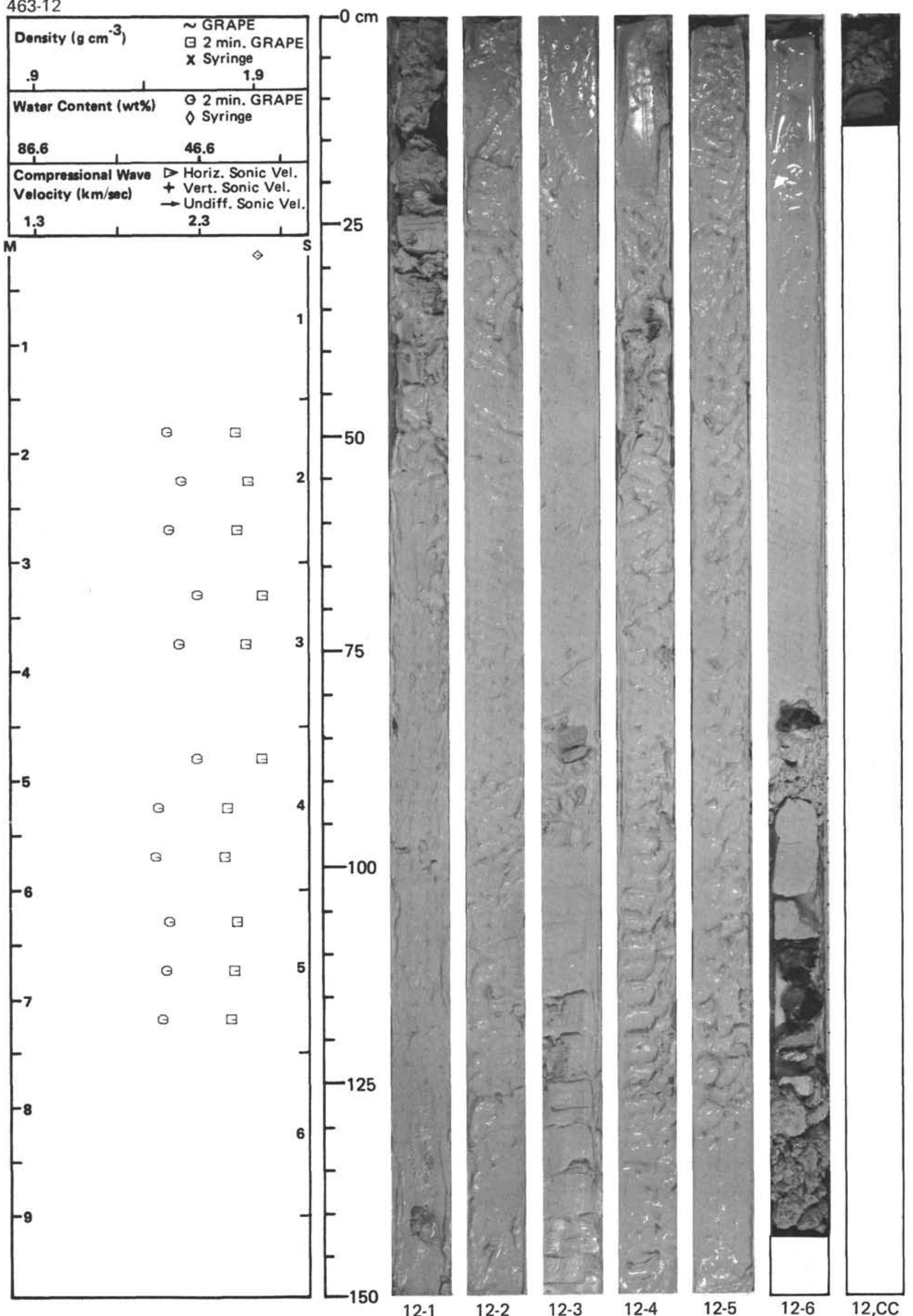


463-13

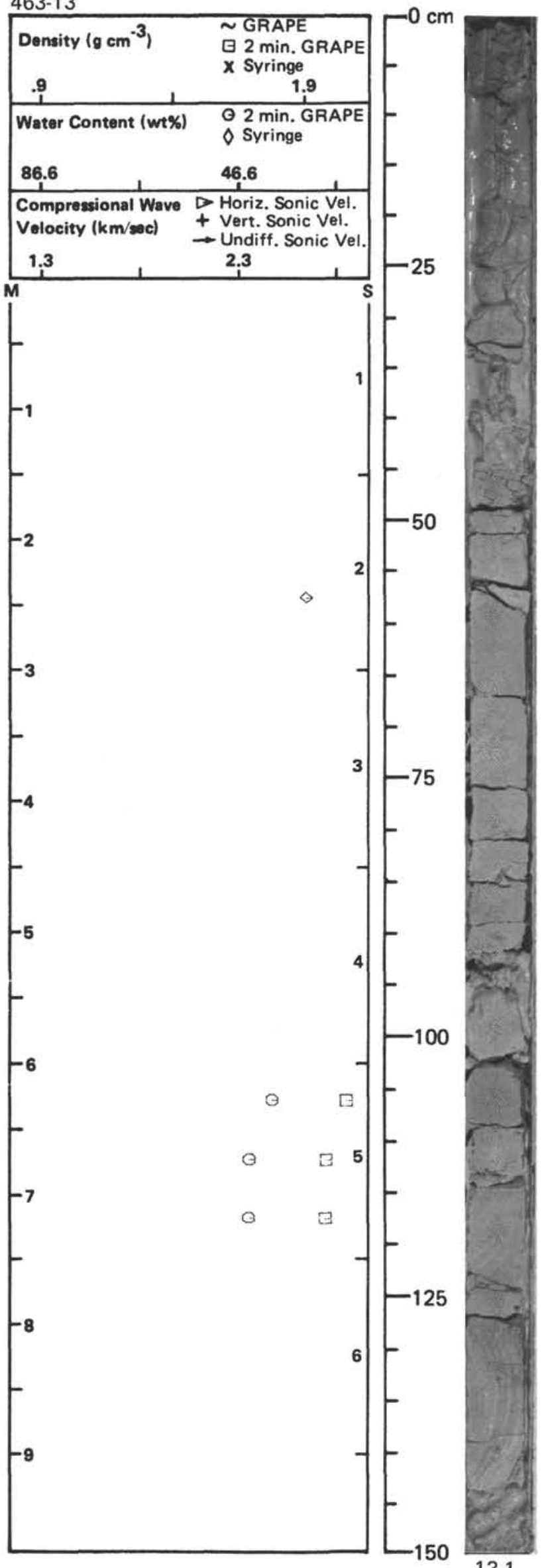

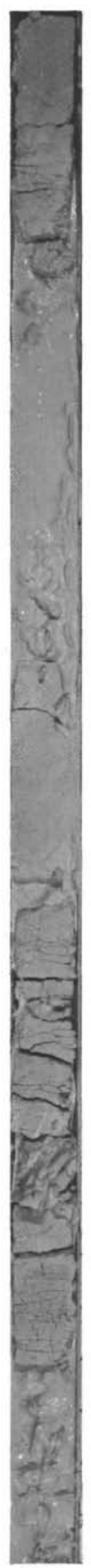

13-2

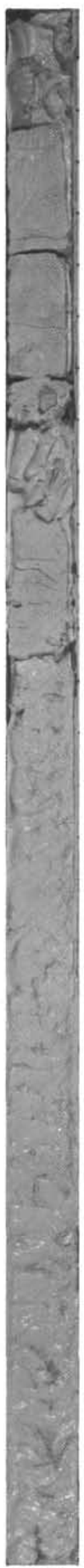

13-3
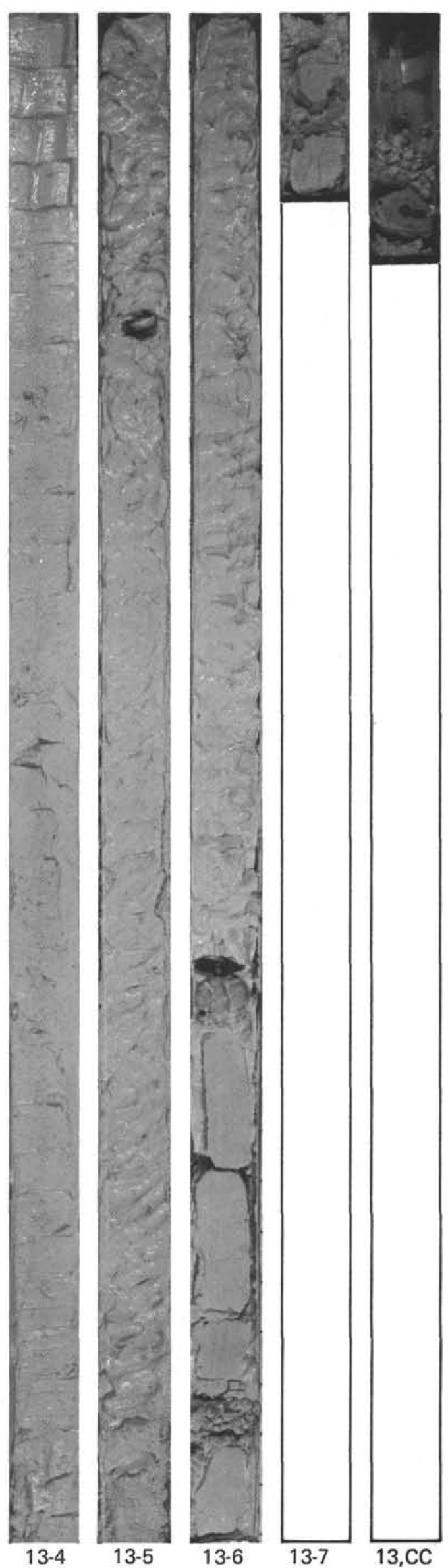


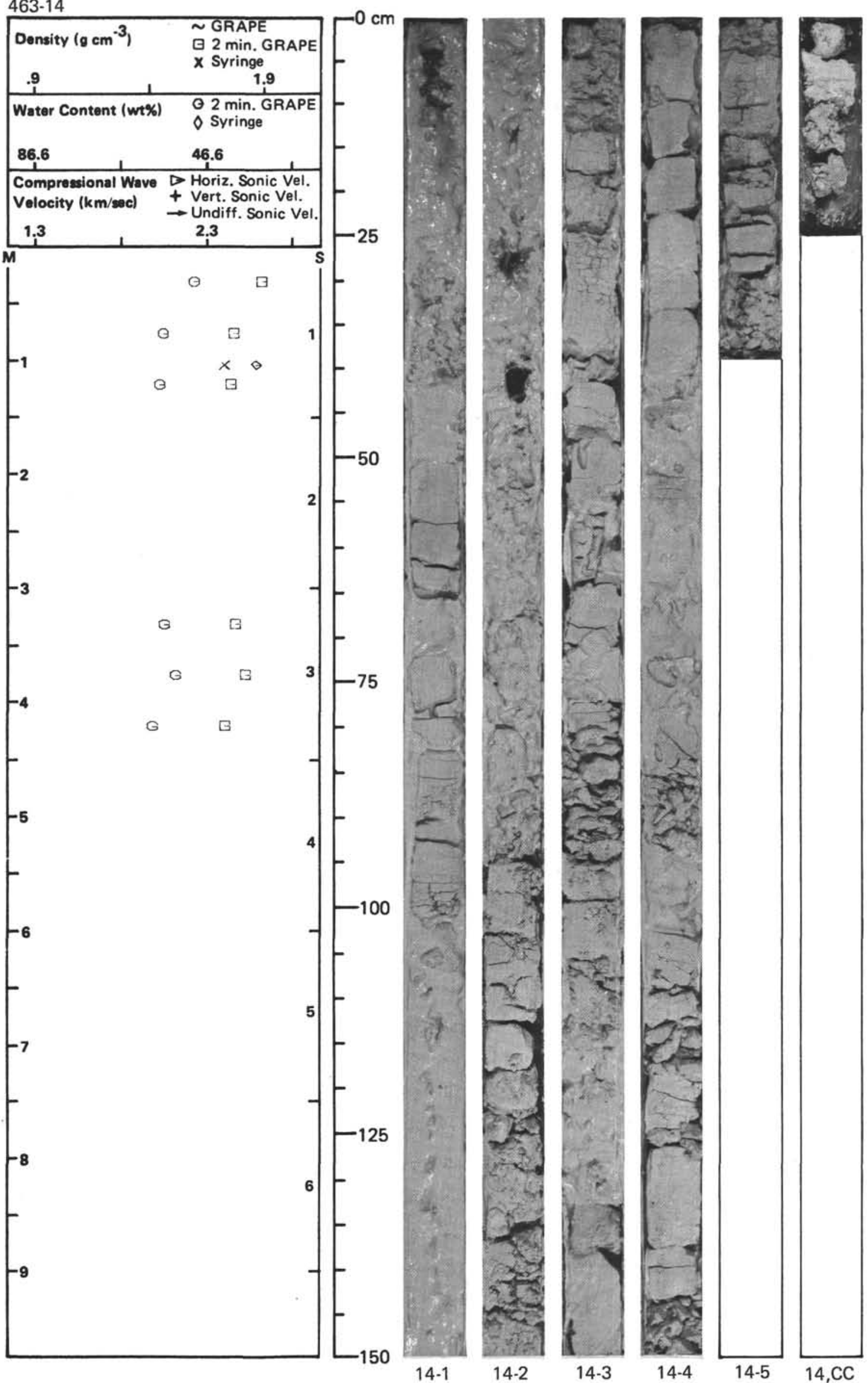


463-15

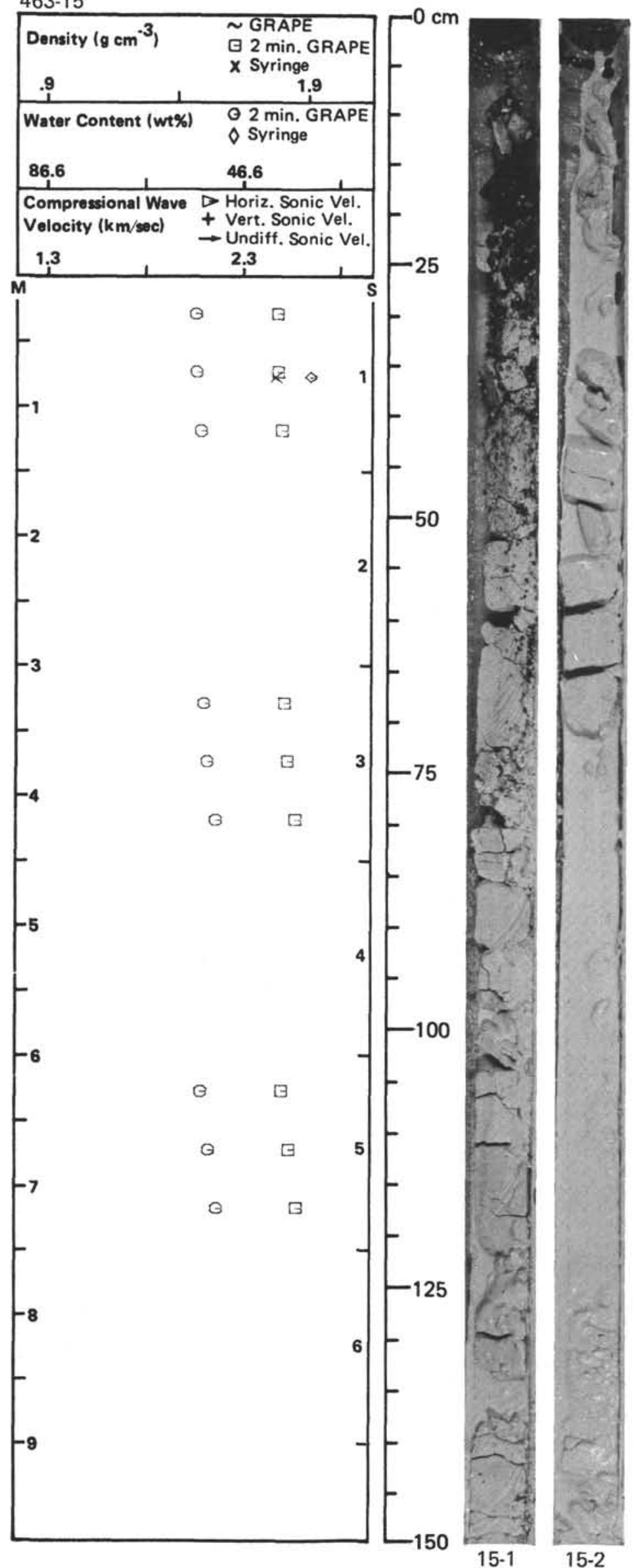

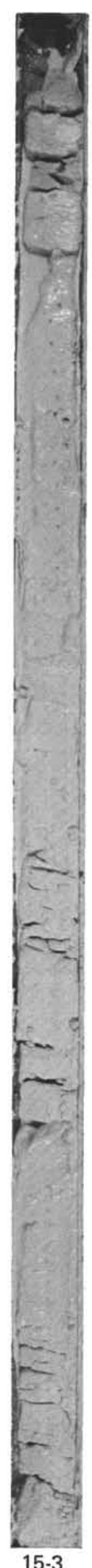

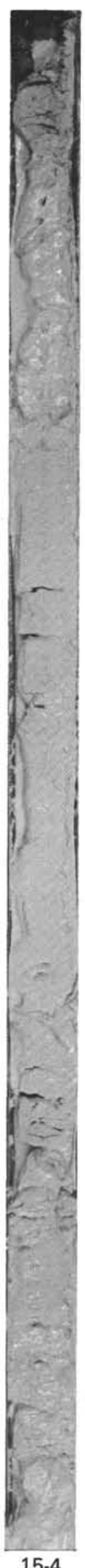

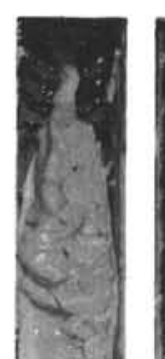

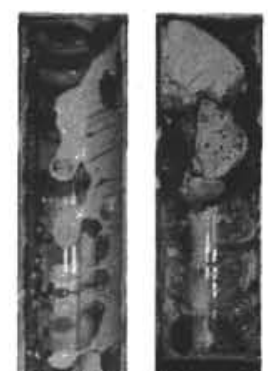

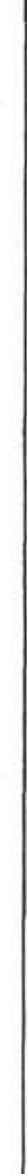
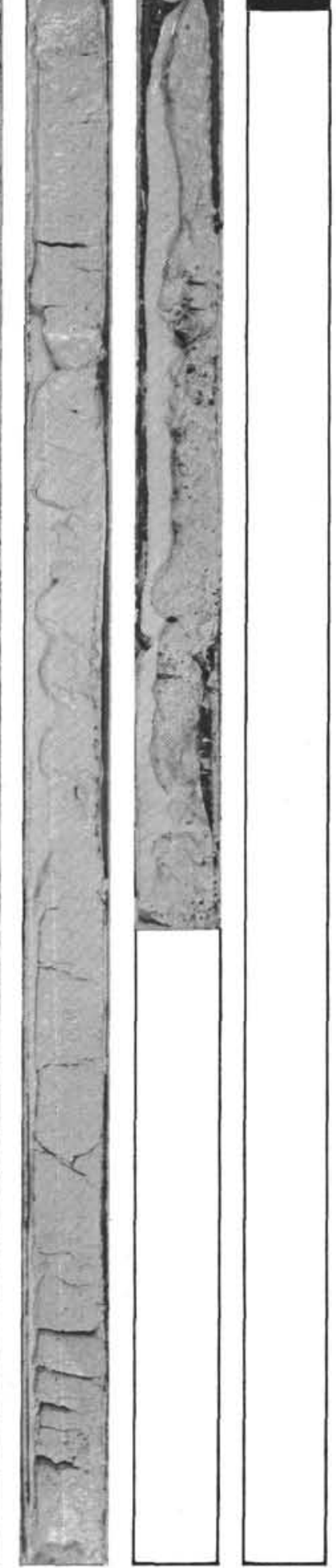

15-5

$15-6$

$15, \mathrm{CC}$ 


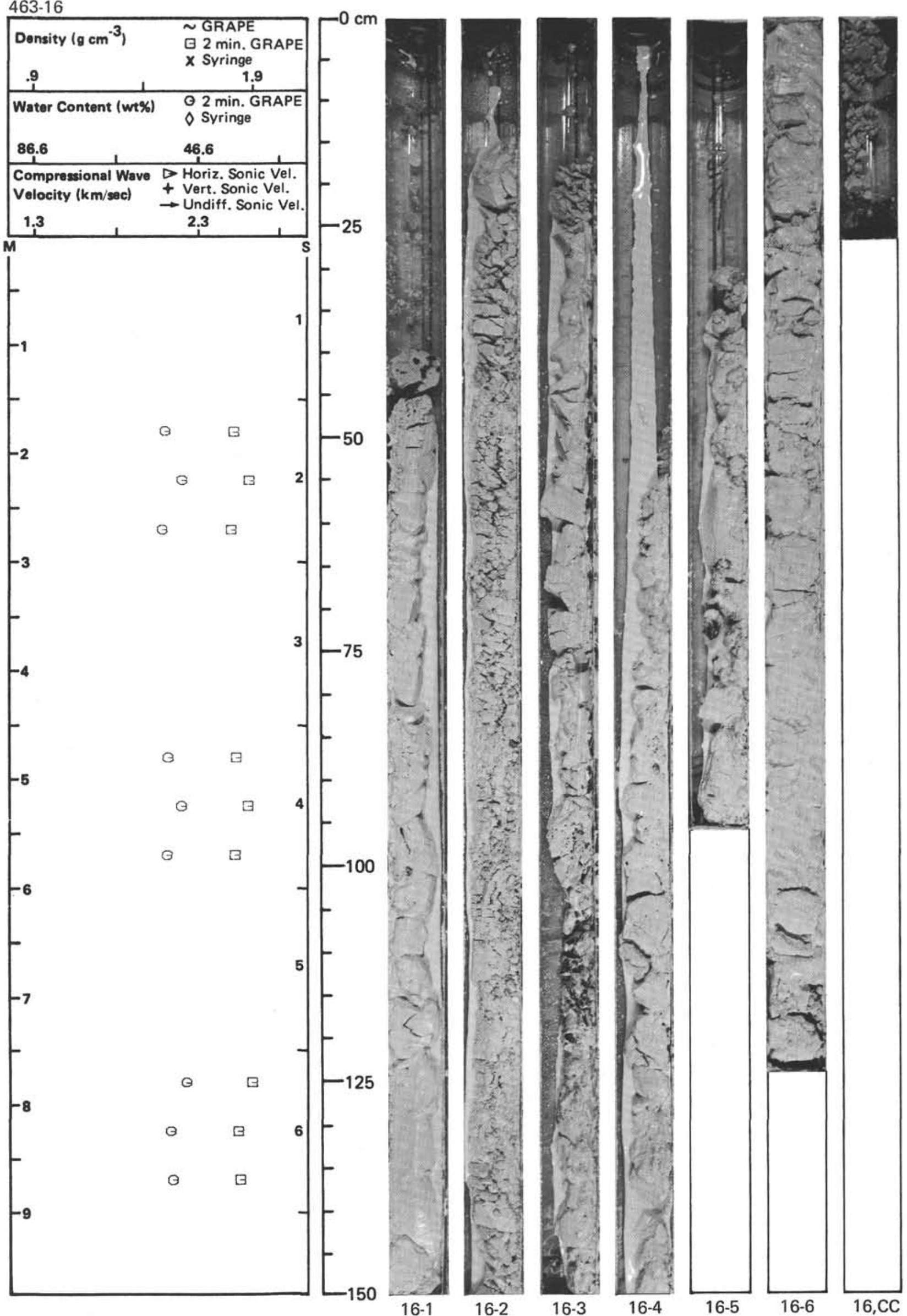


463-17

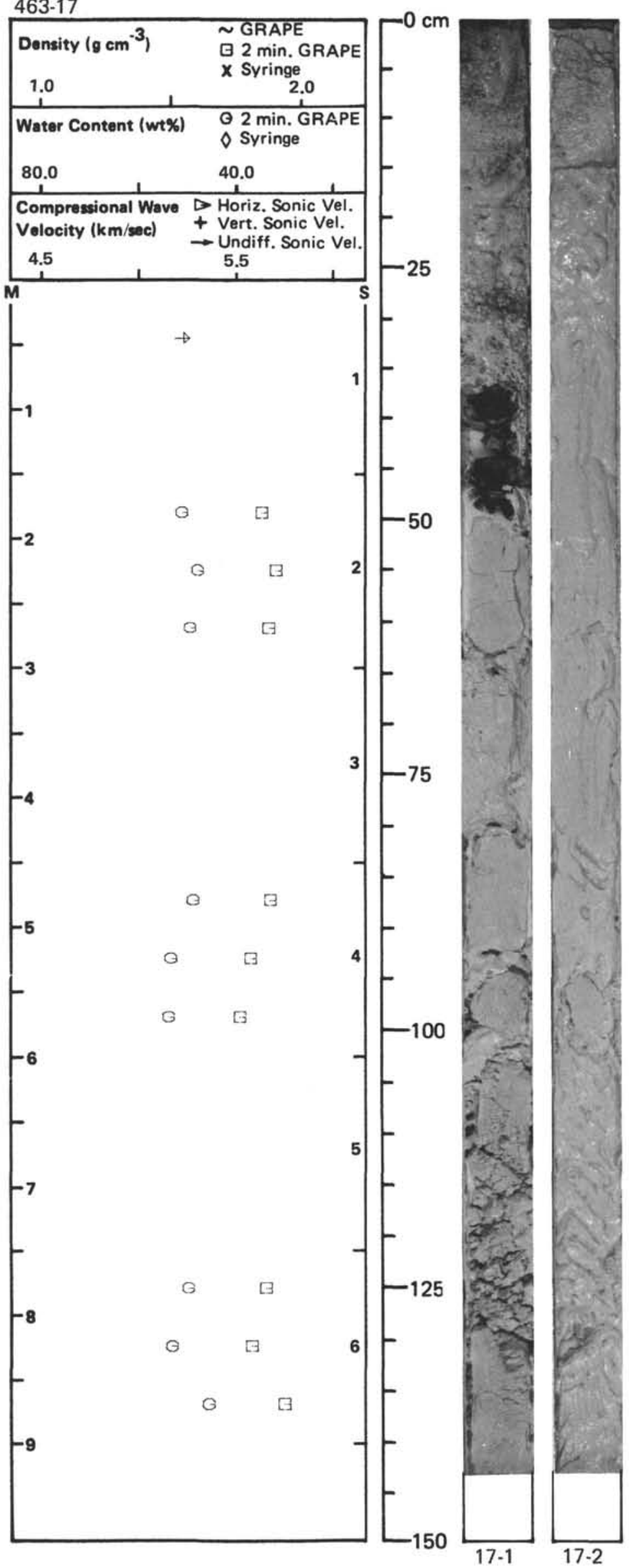

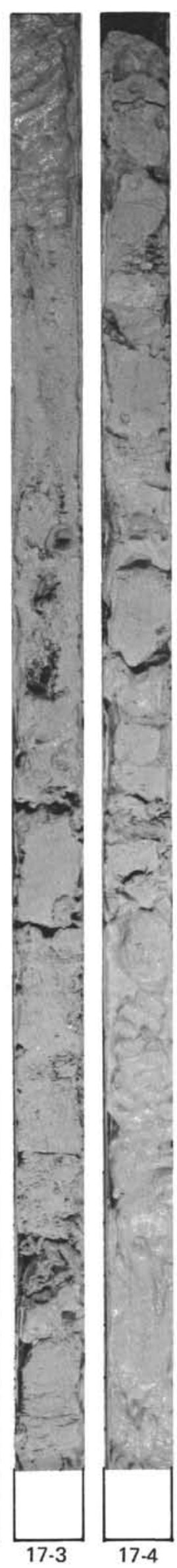

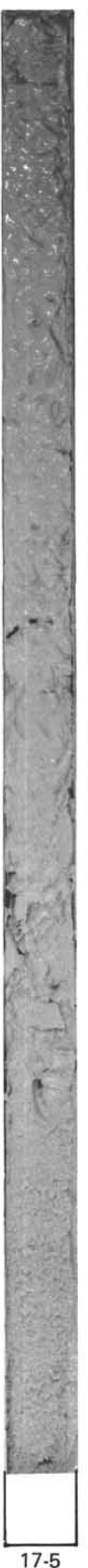

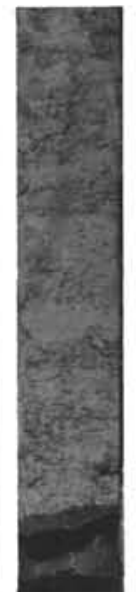

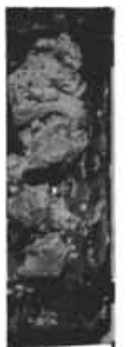

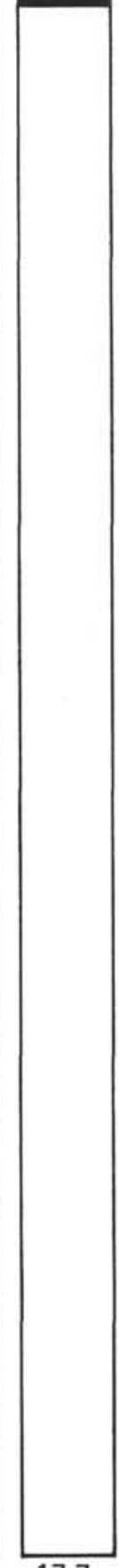

17-6

$17-7$

17, CC 
463-18 NO DATA

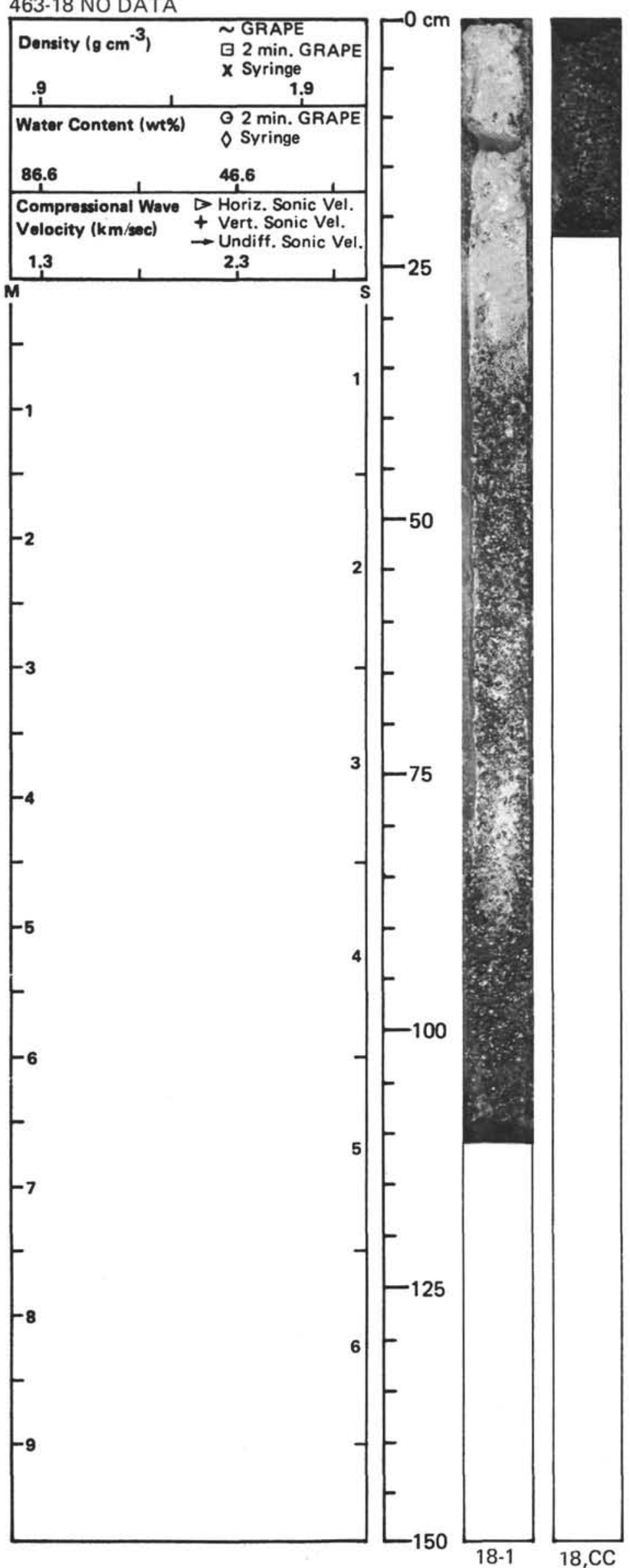



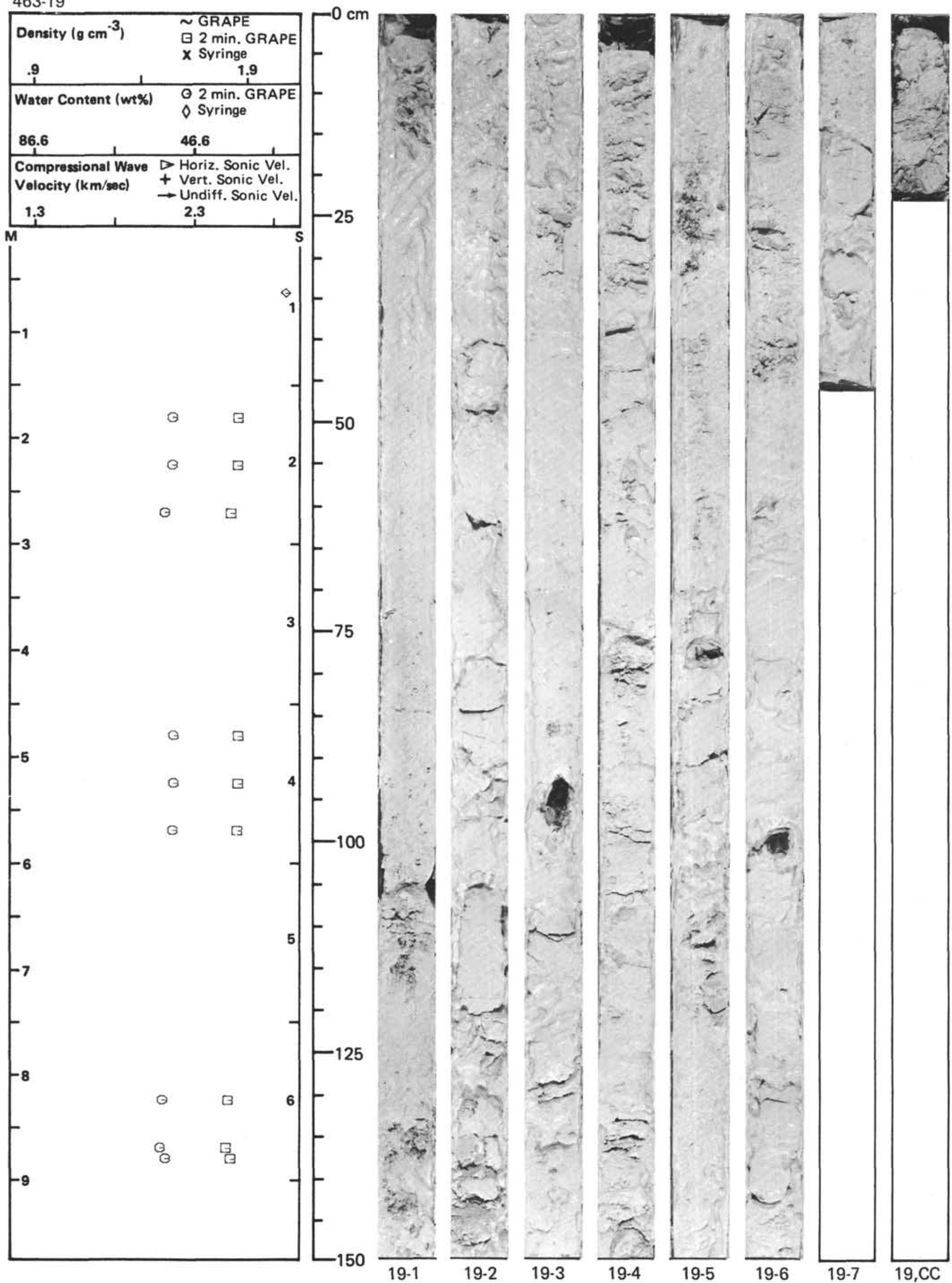

19-7 


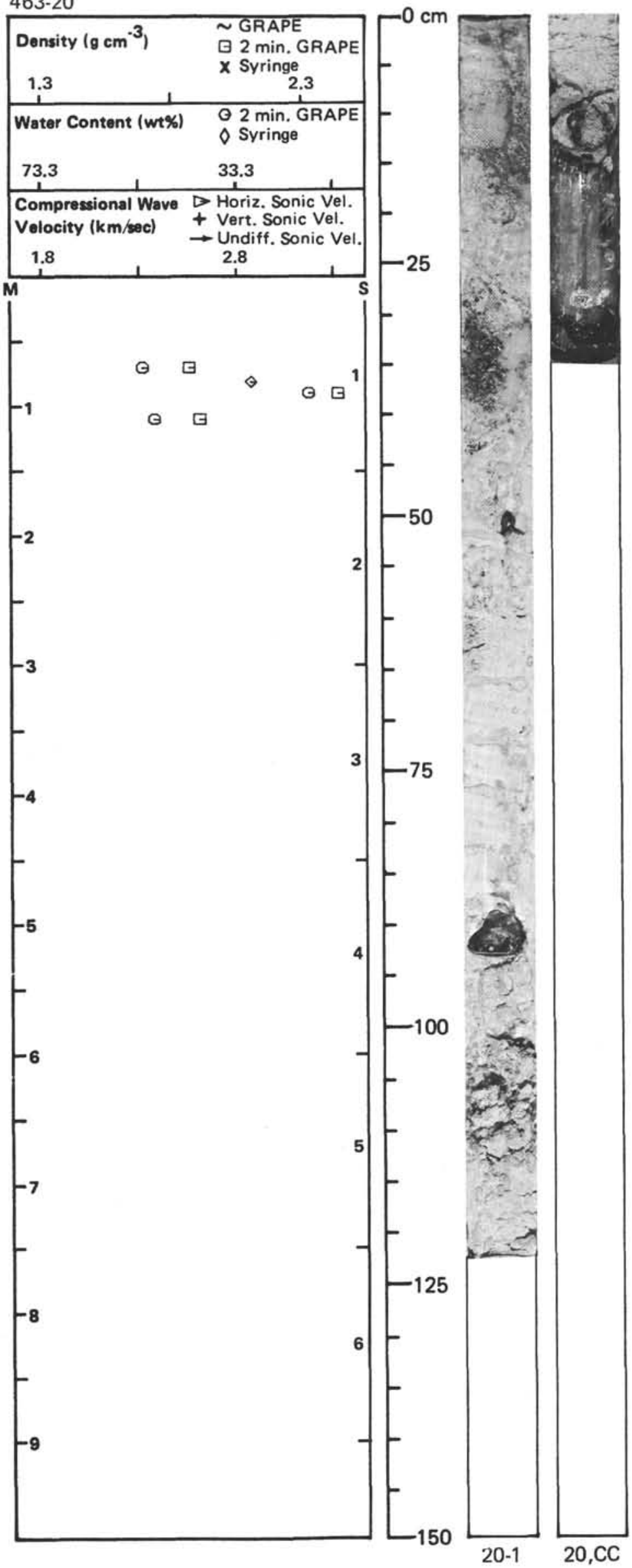




\section{3-21}

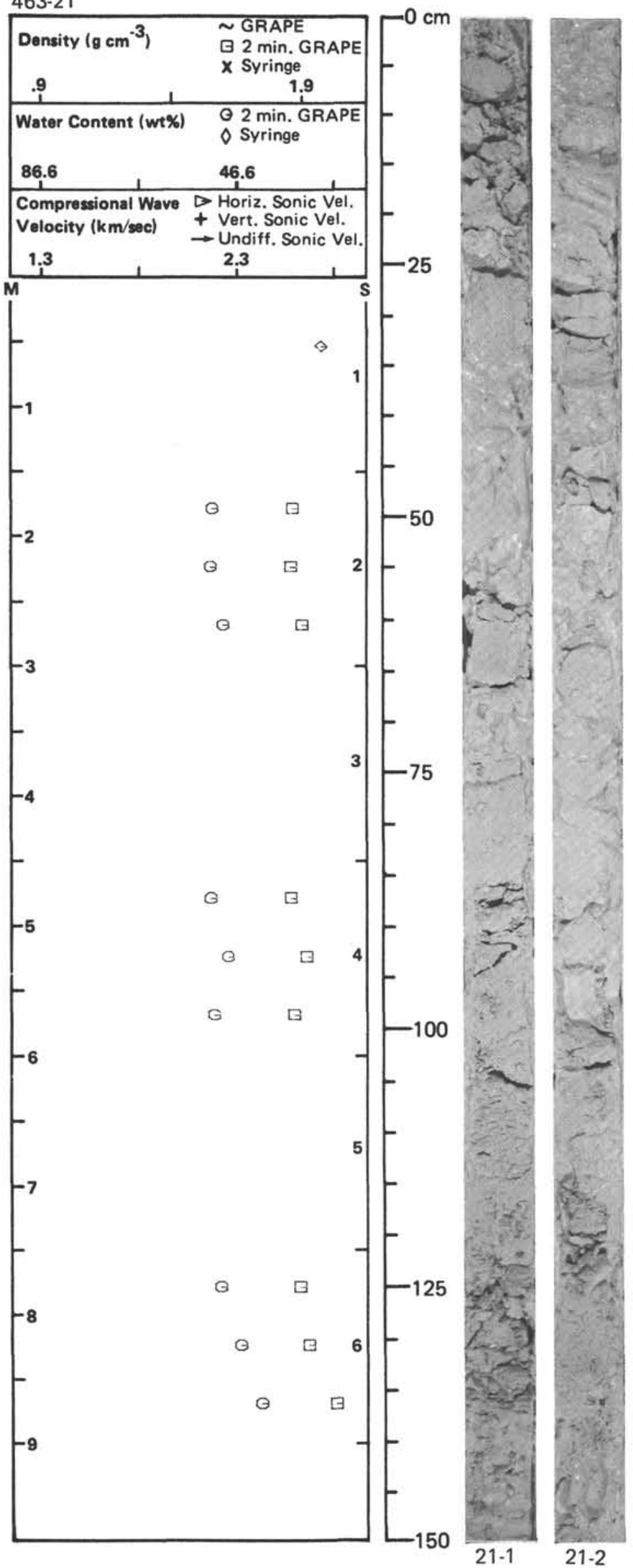

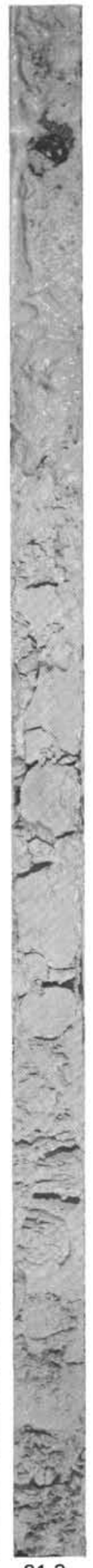

21-3
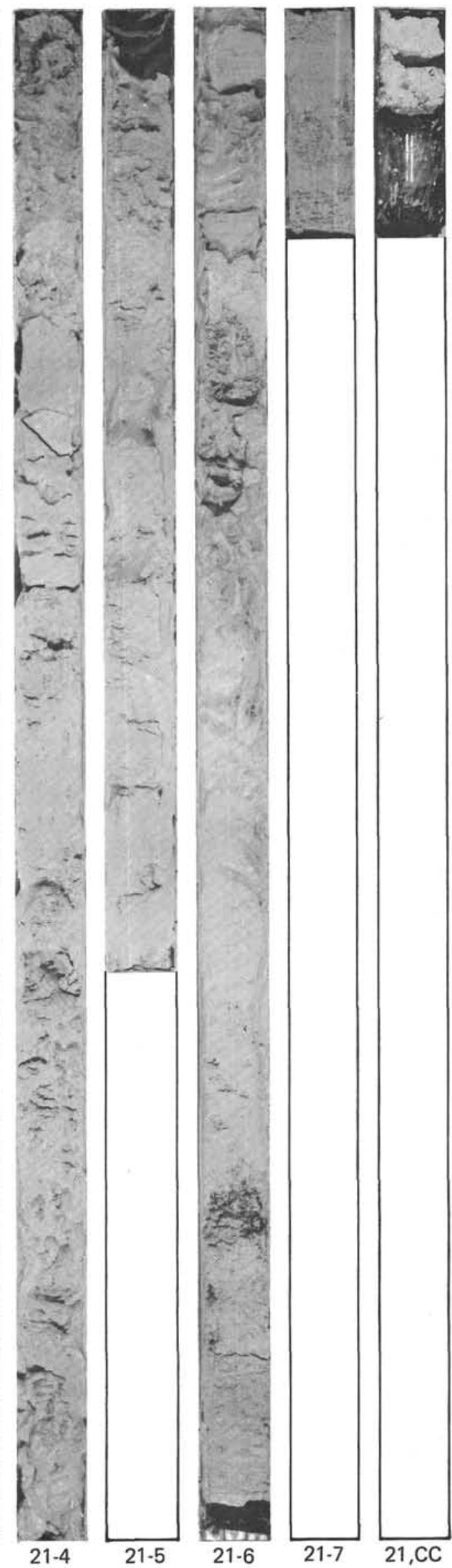
463-22

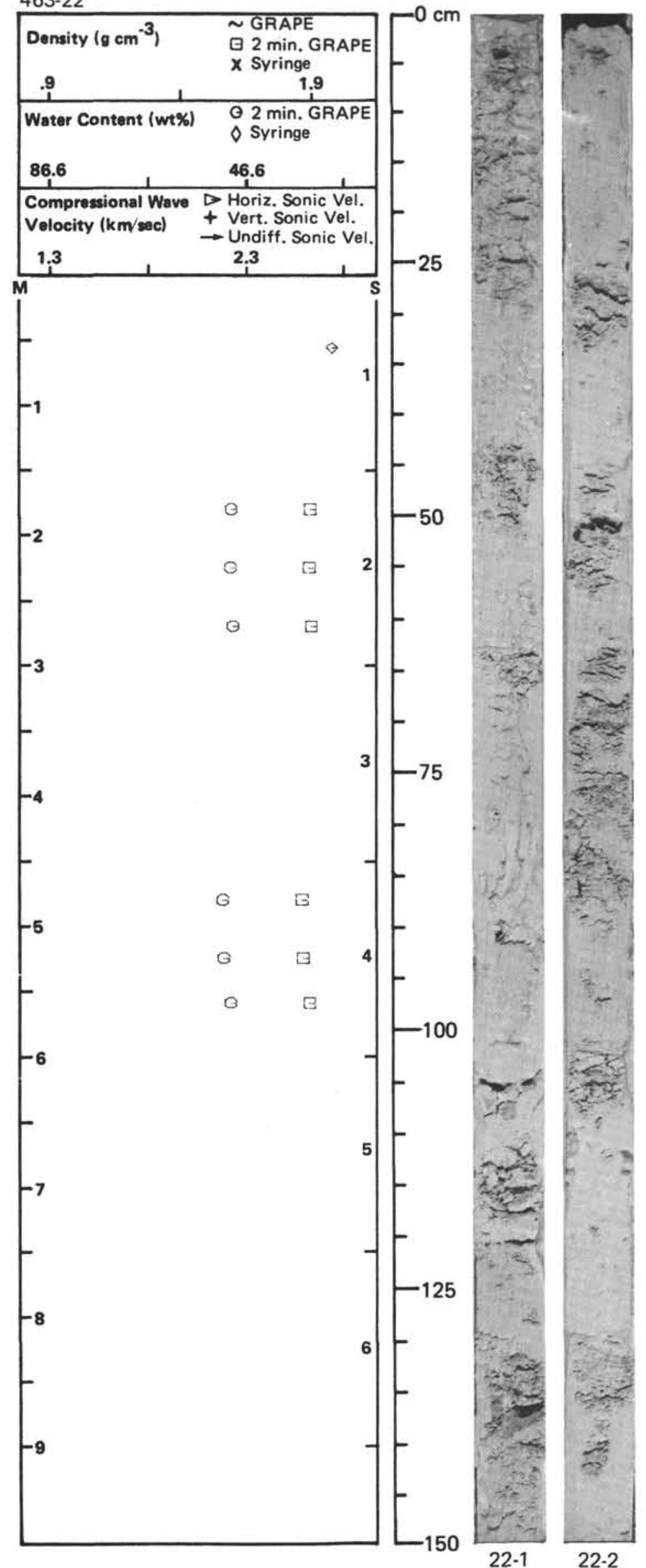

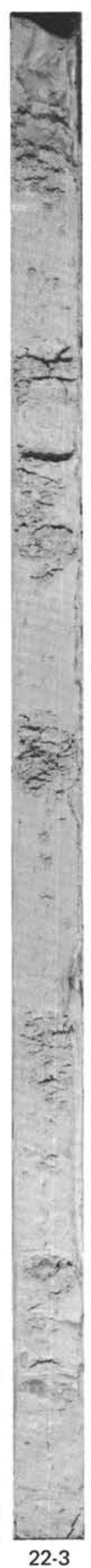
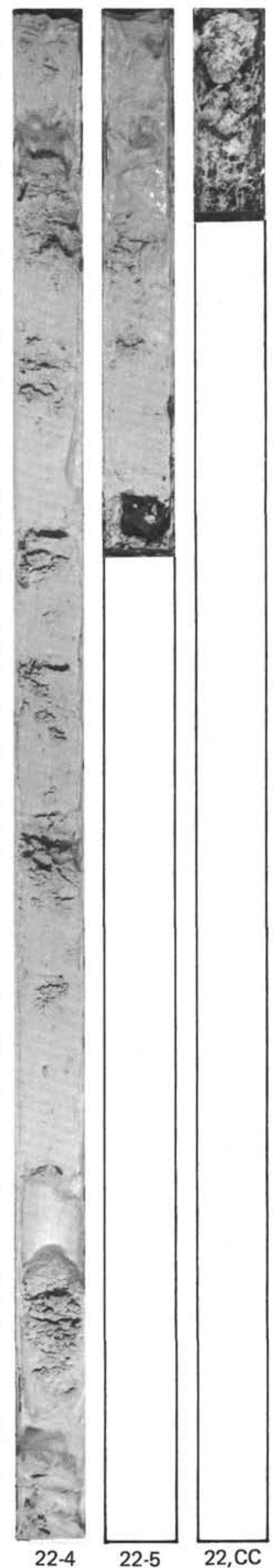

$22, \mathrm{CC}$ 

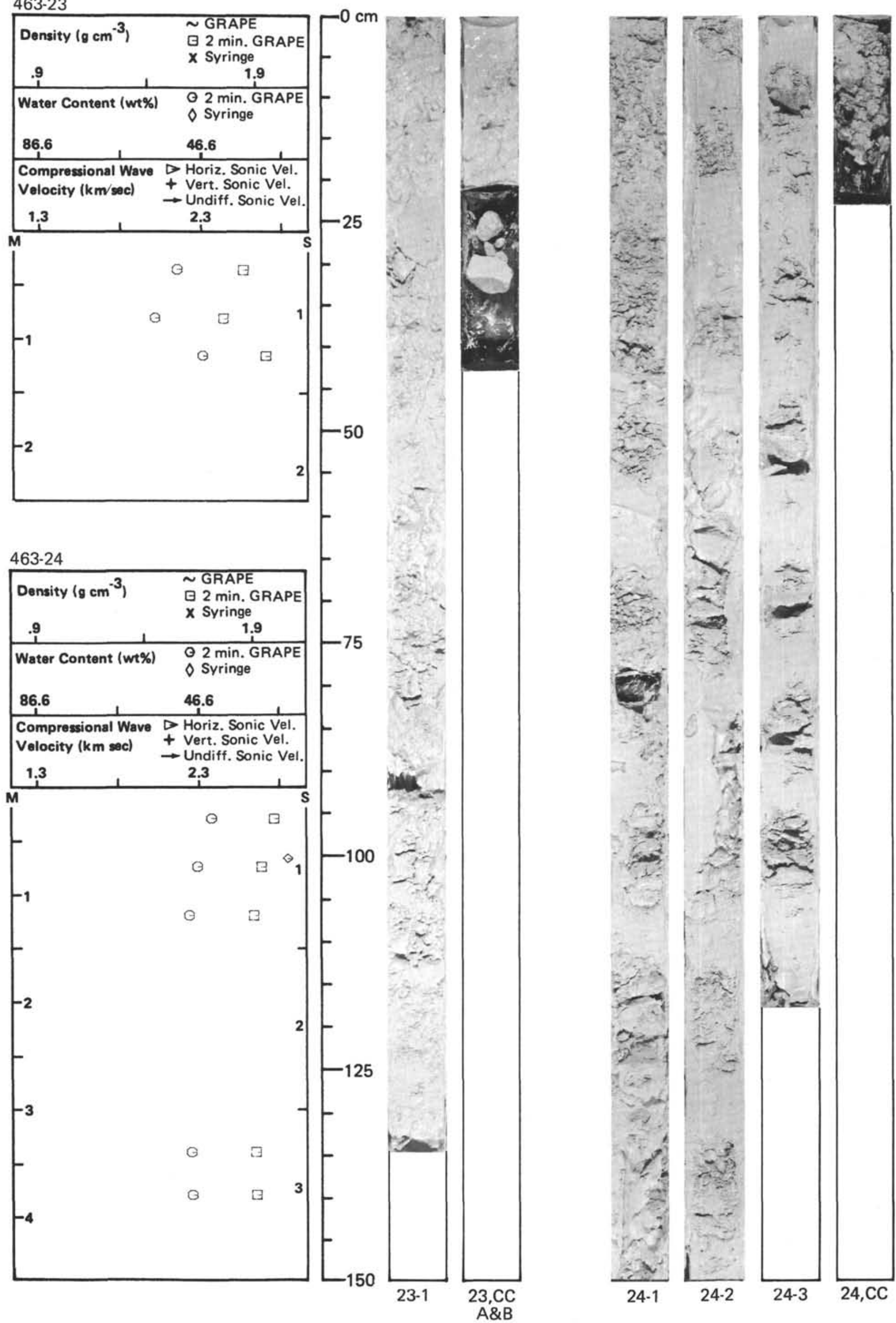


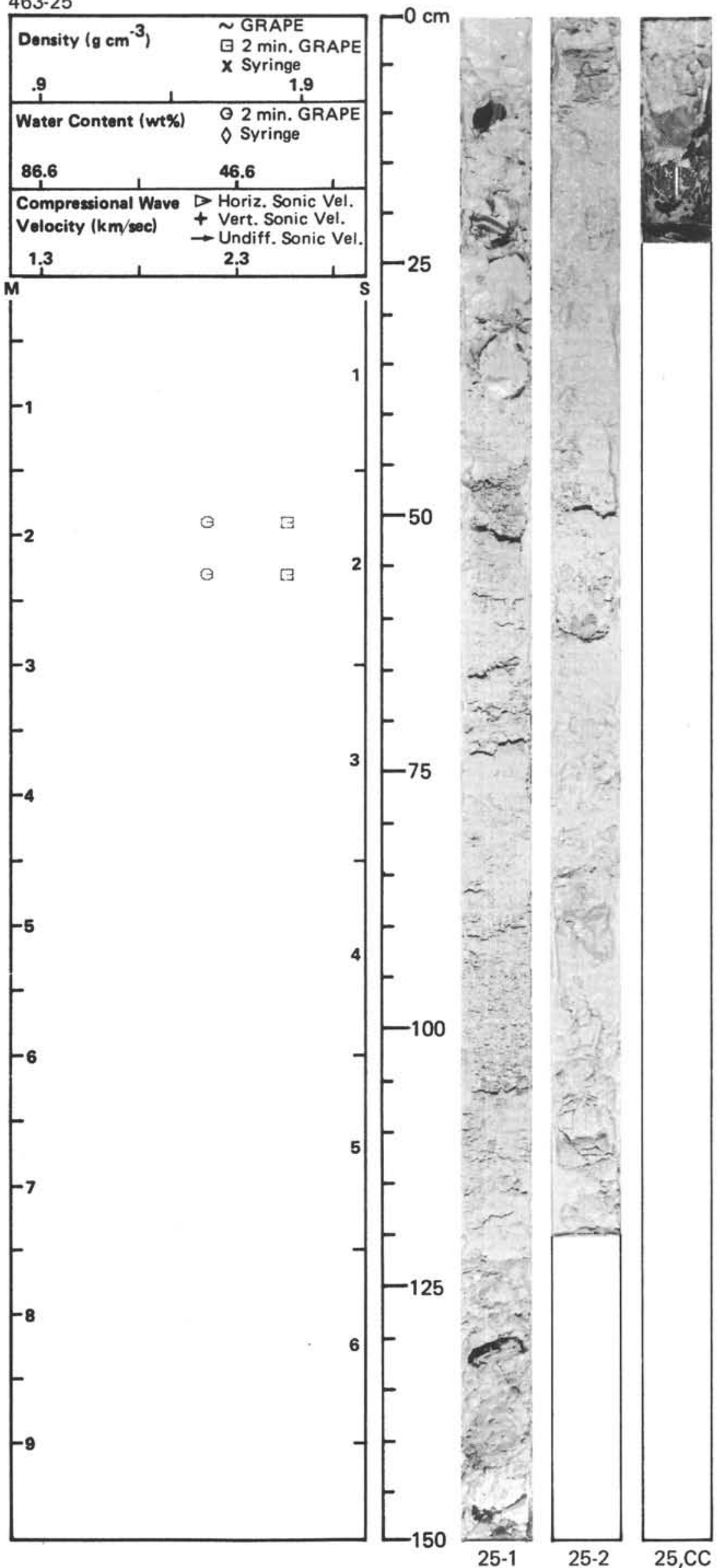


463-26

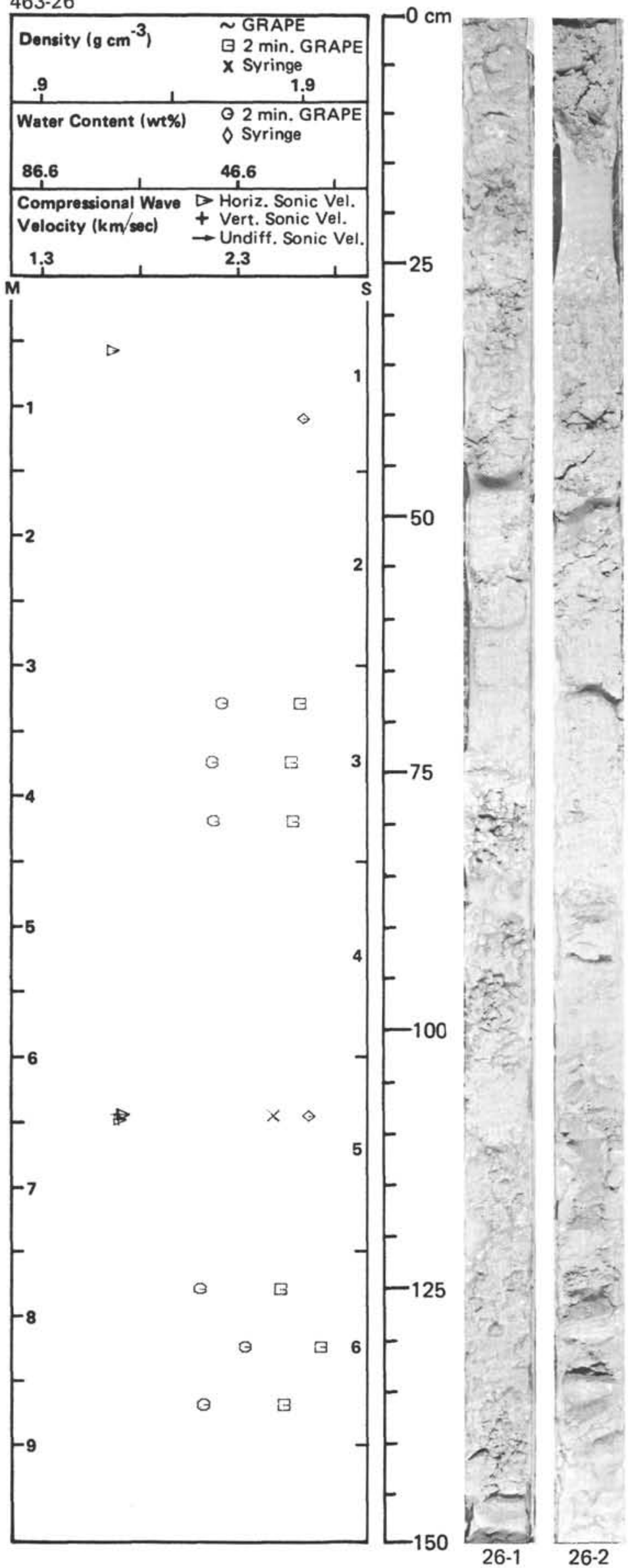

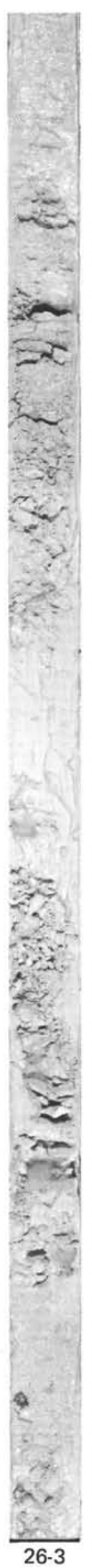

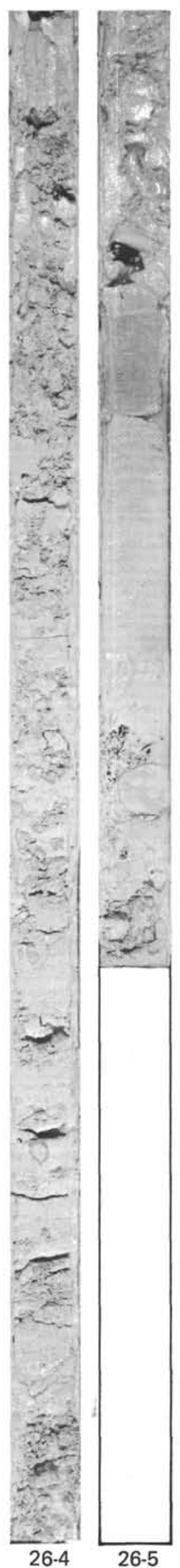

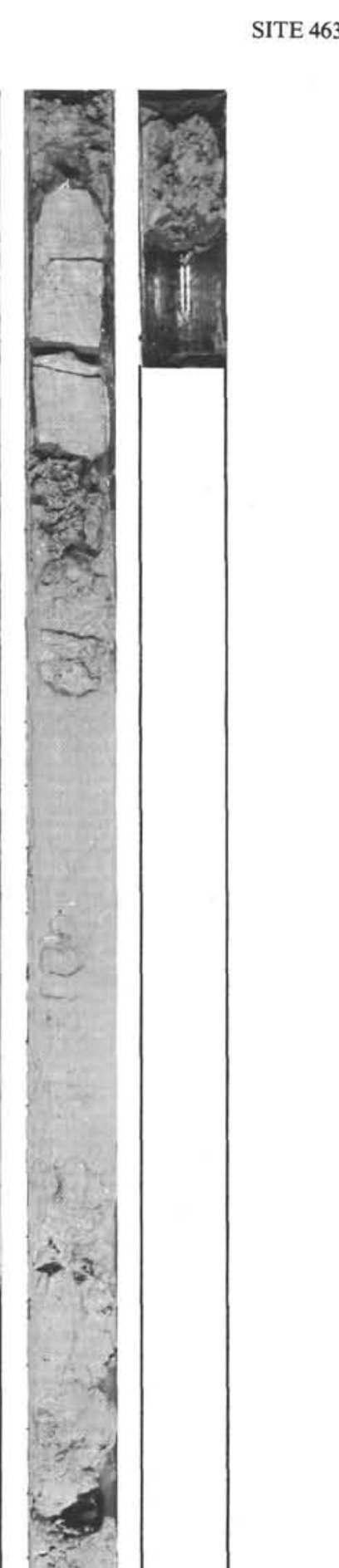

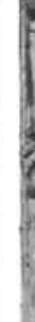
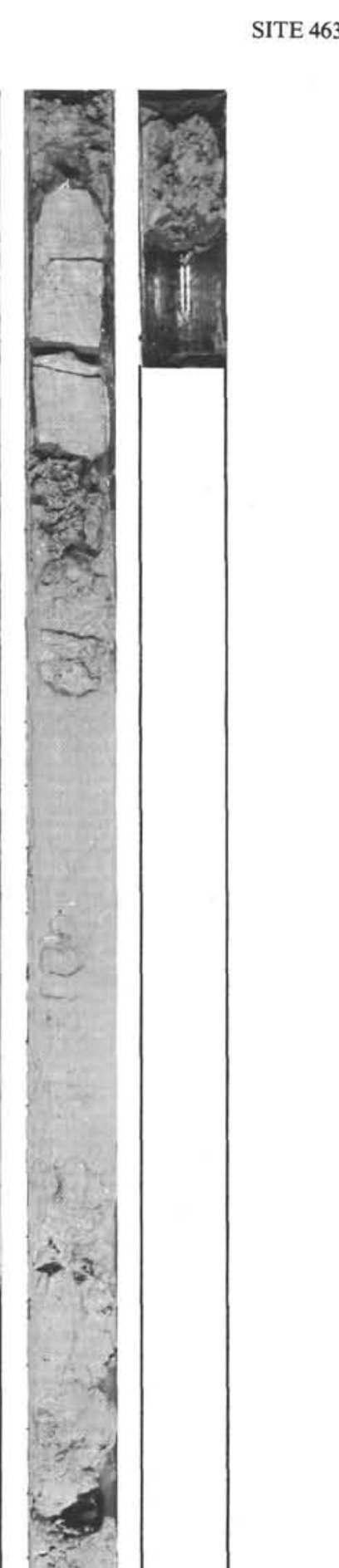

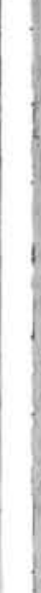
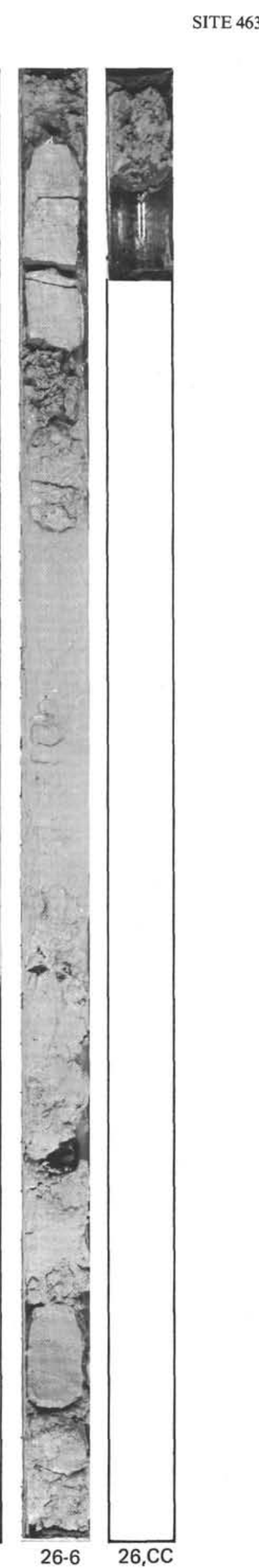


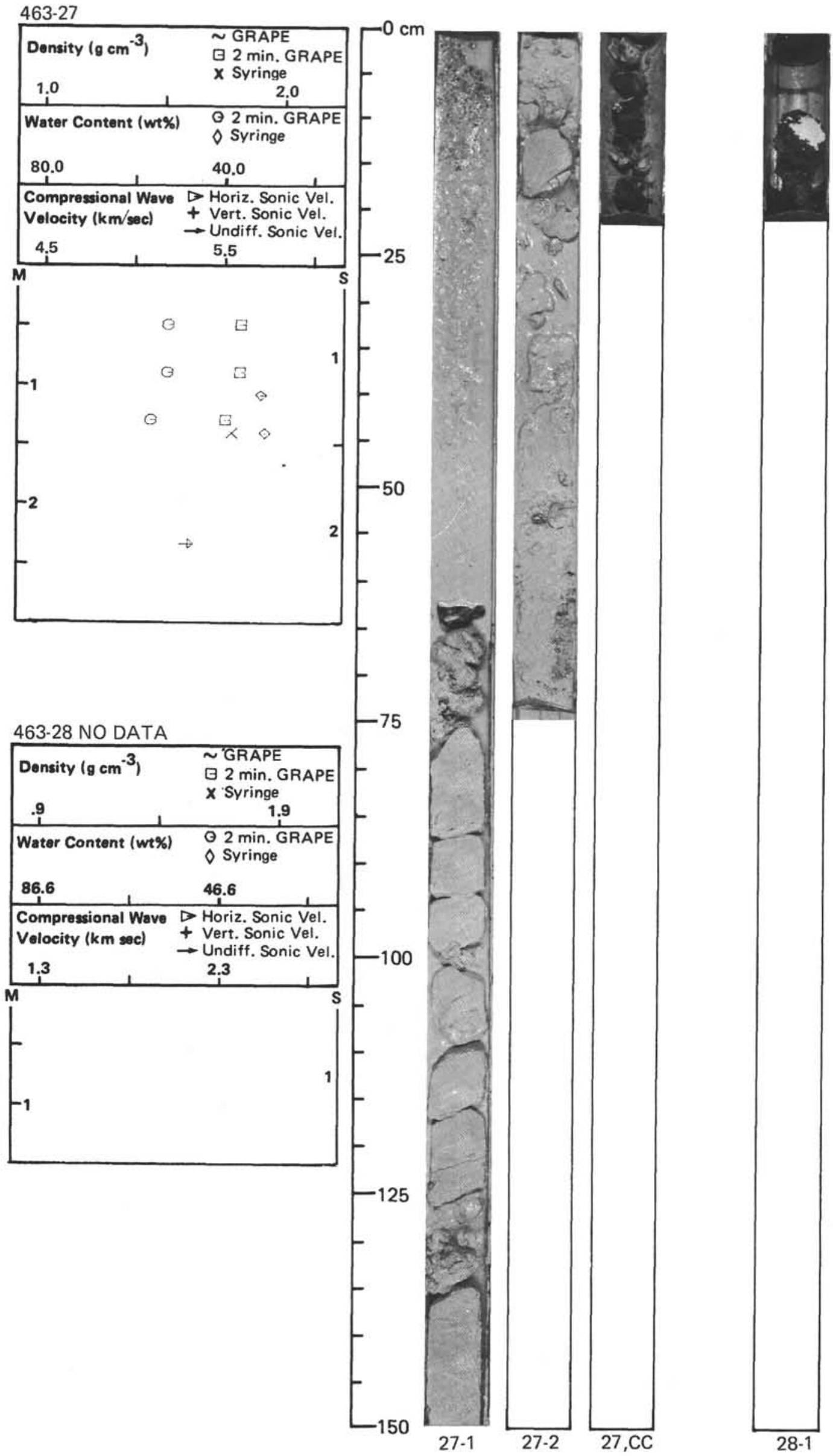


463-29

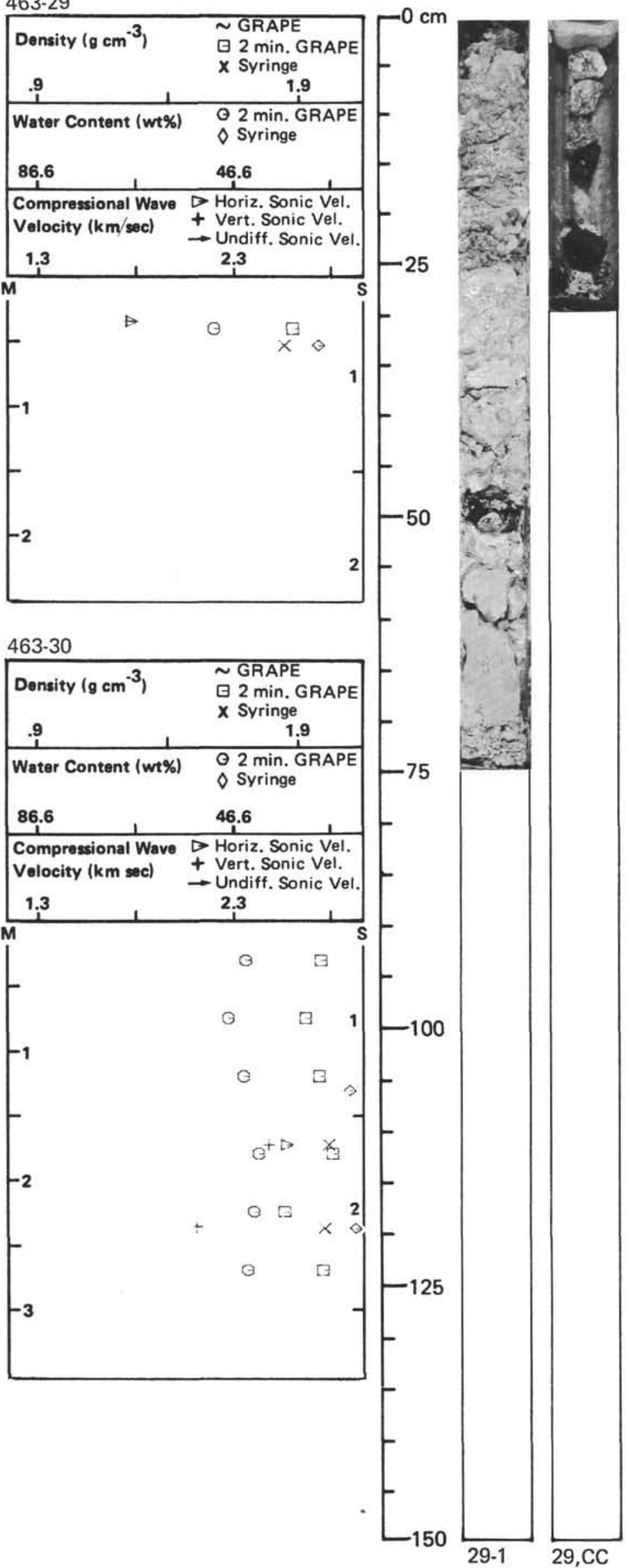

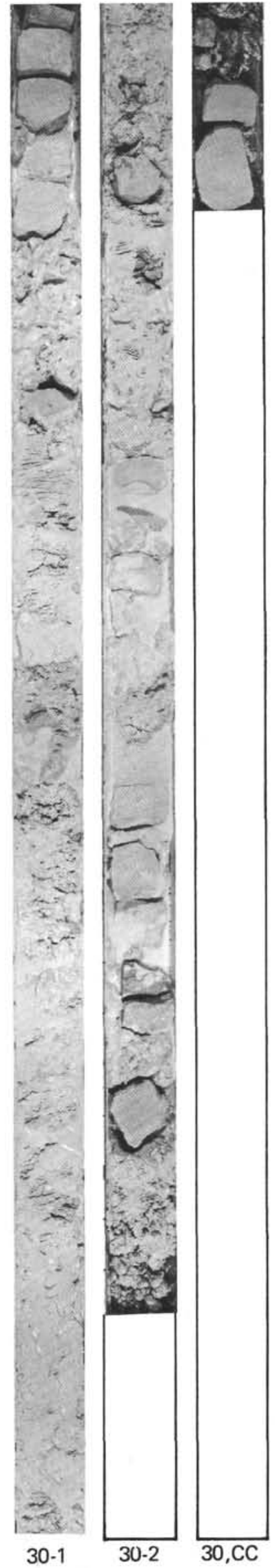


SITE 463

463-31 (463-32, 33 NO DATA)

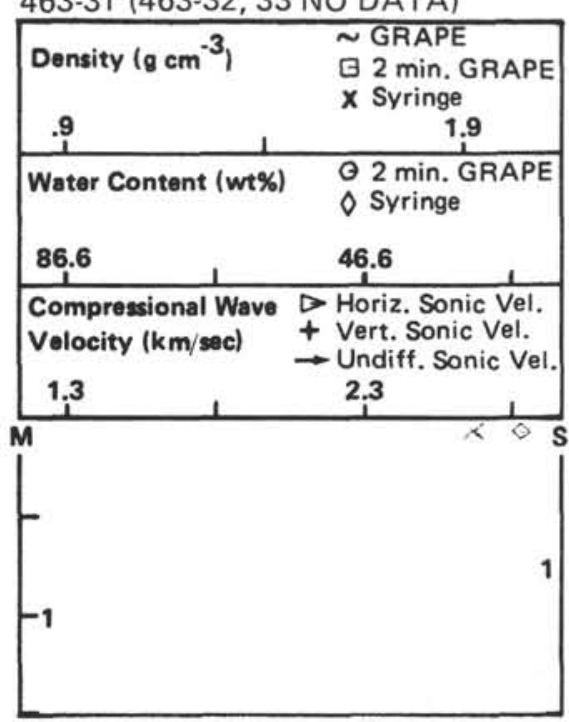

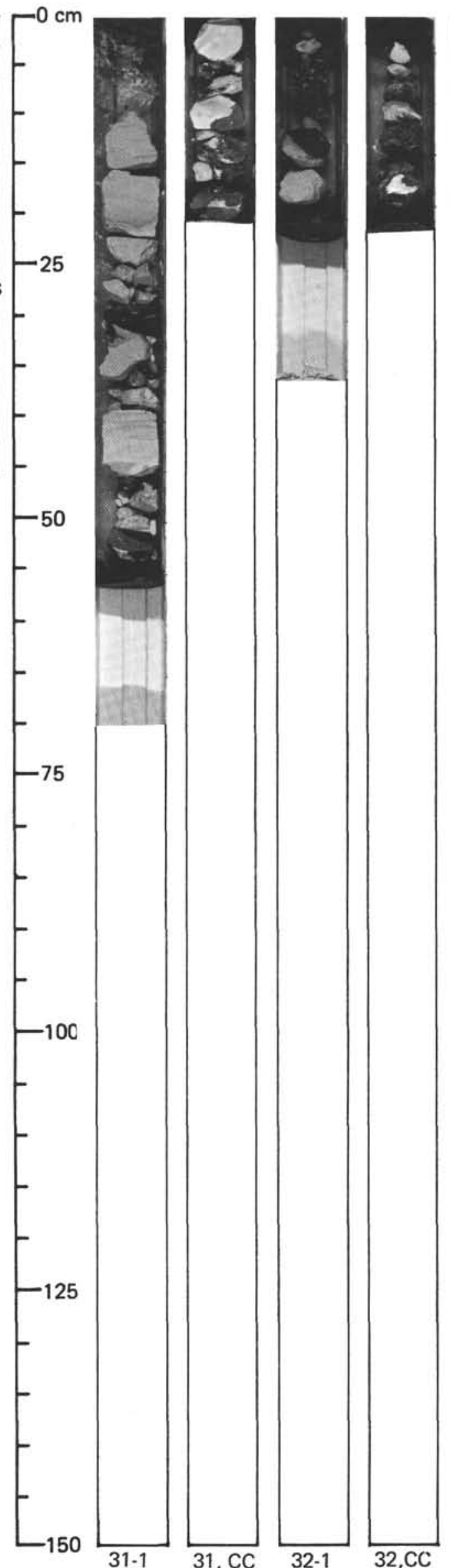

$31-1 \quad 31, \mathrm{CC}$

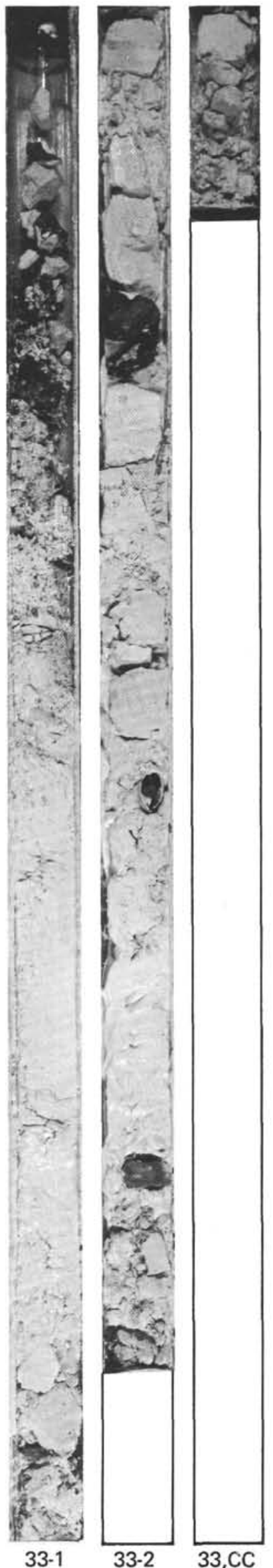




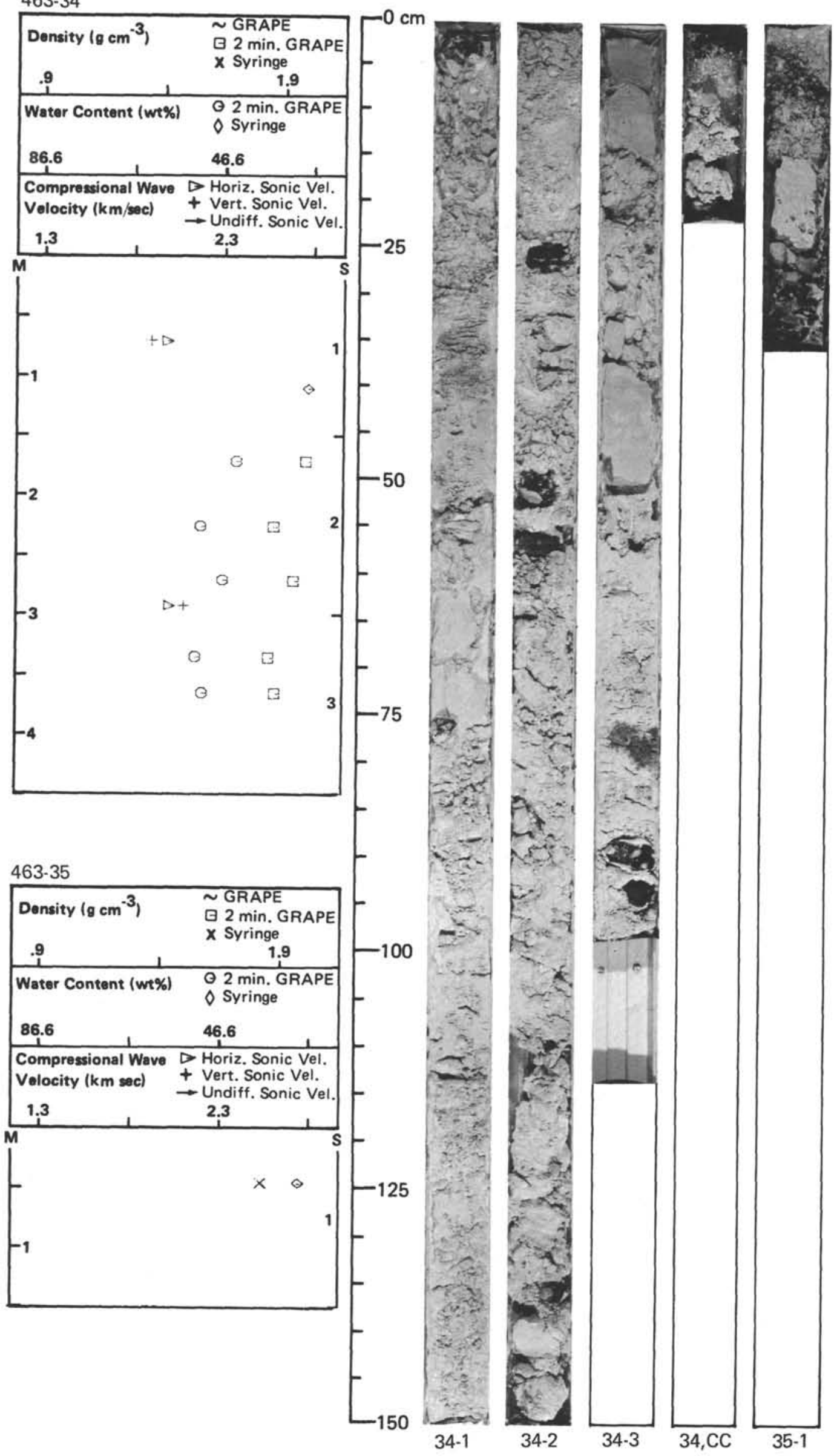




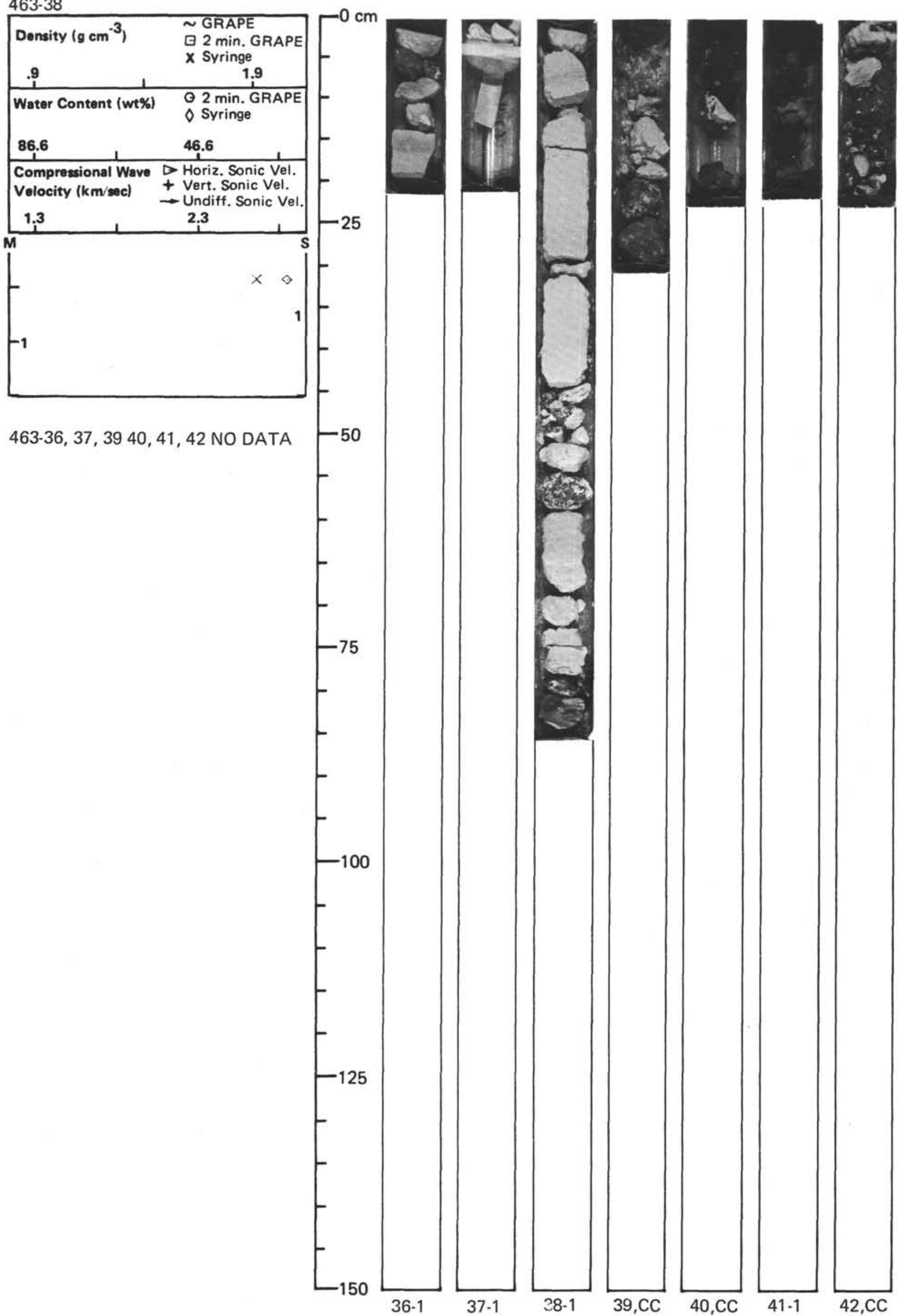


463-43

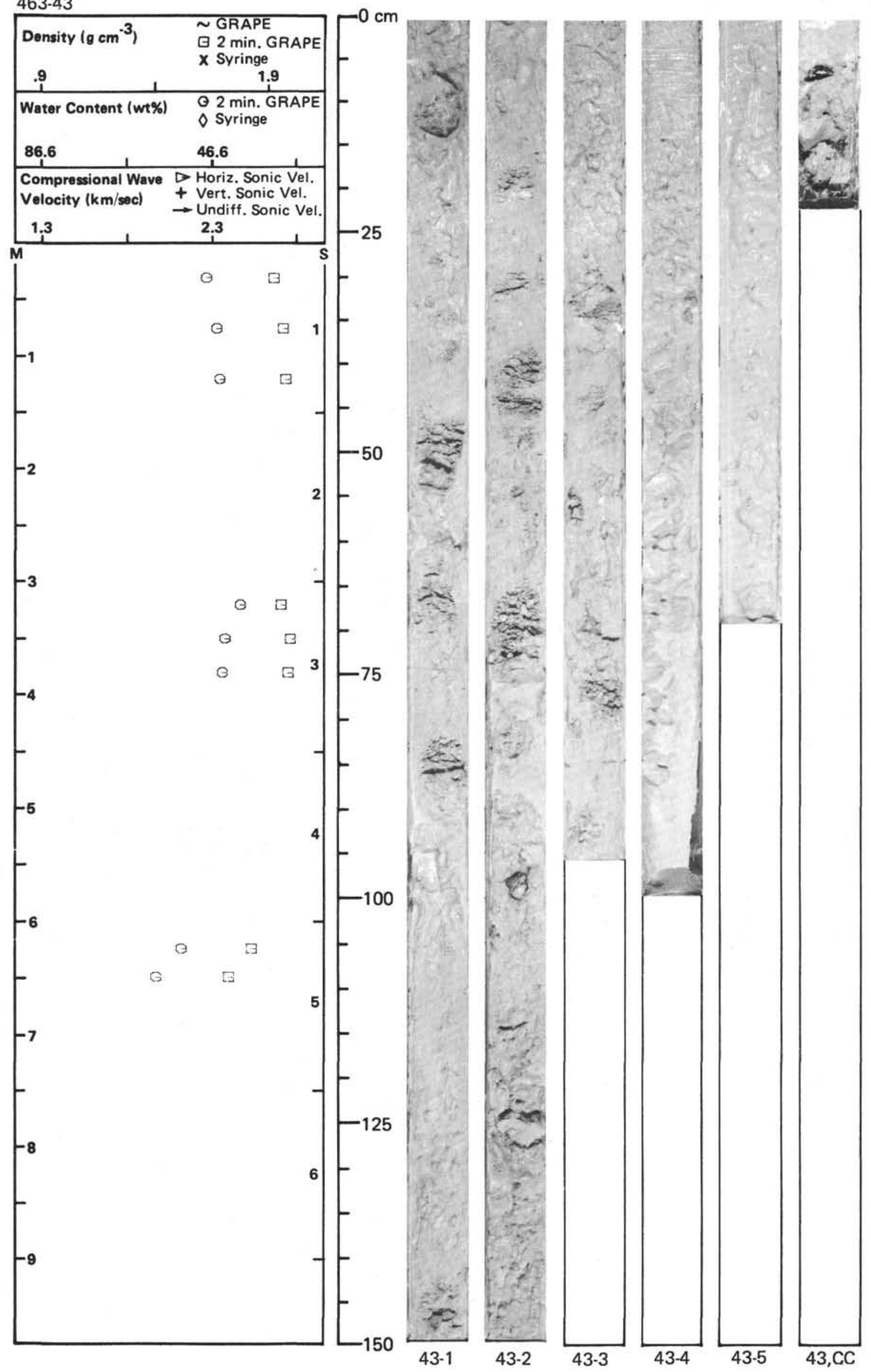


$463-44,45,46,47$ NO DATA

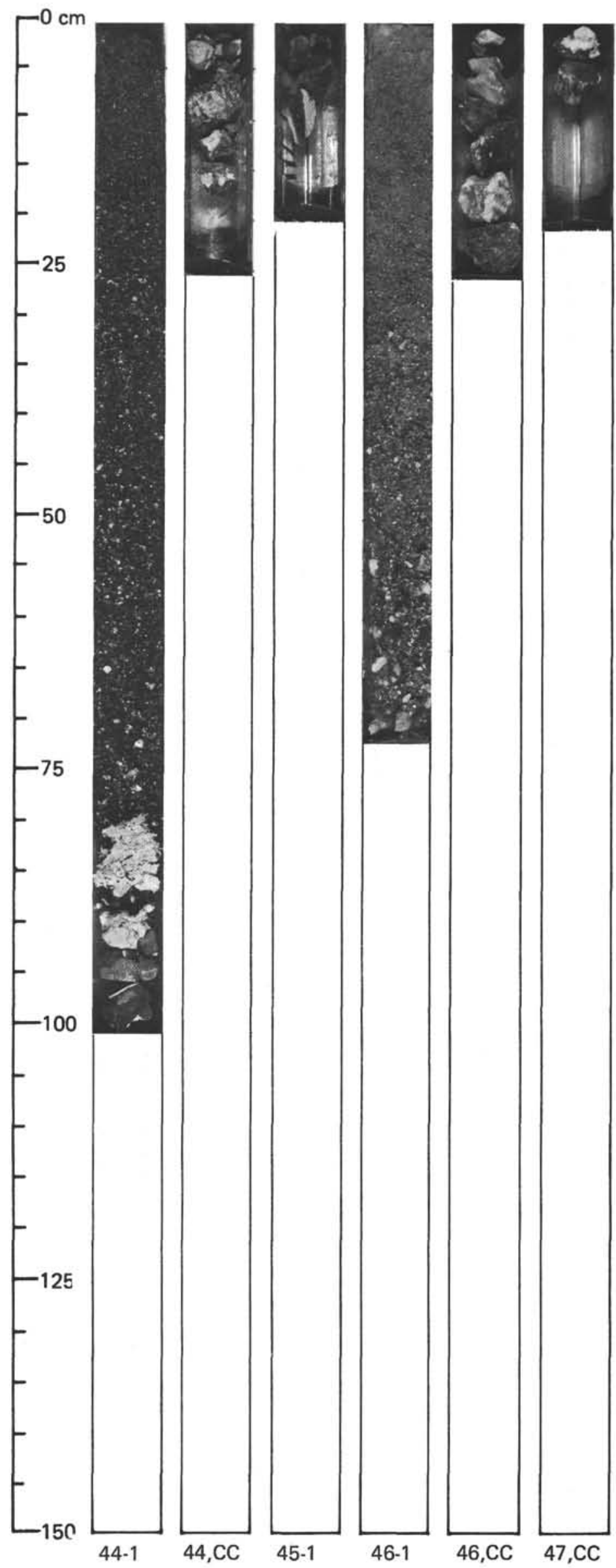




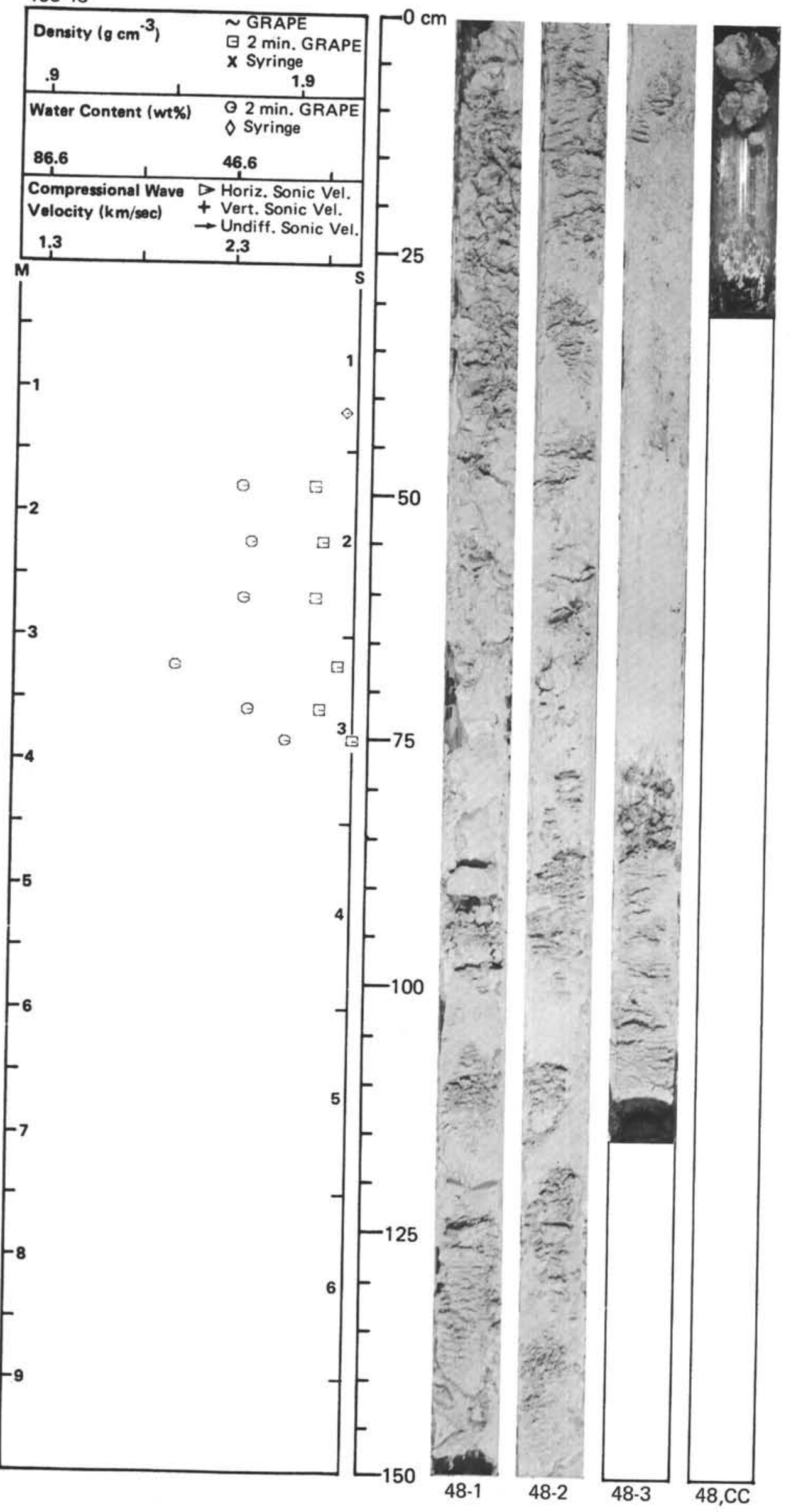


SITE 463

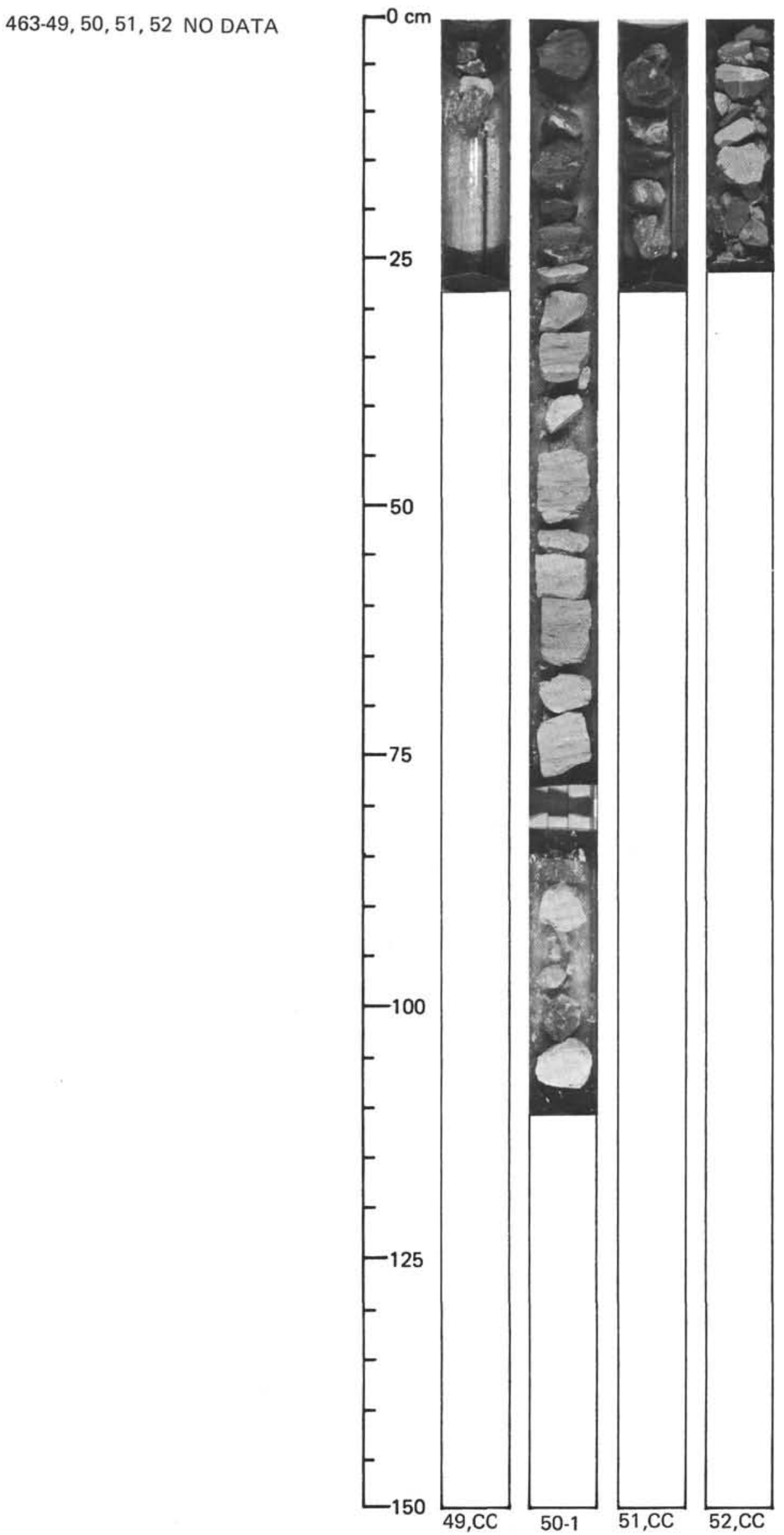


463-53

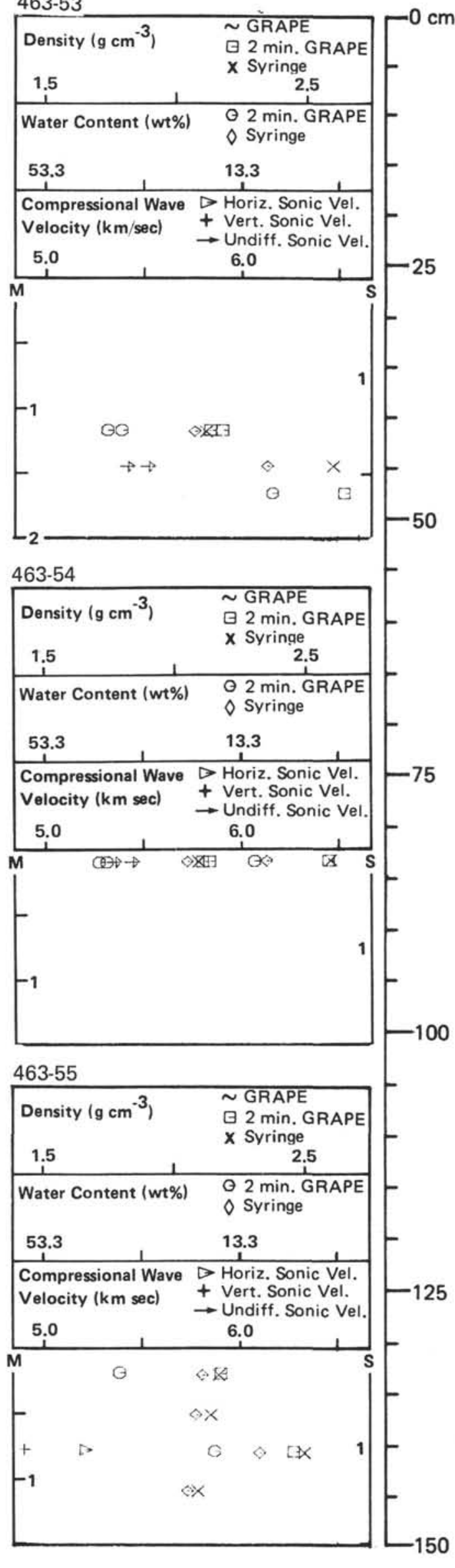

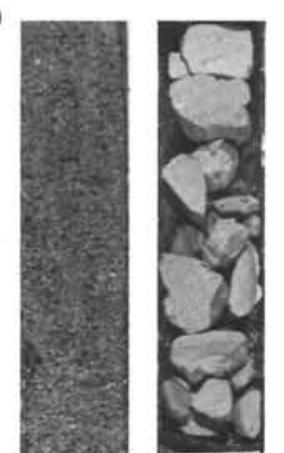

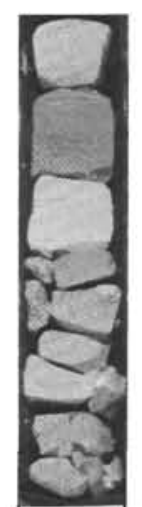

0
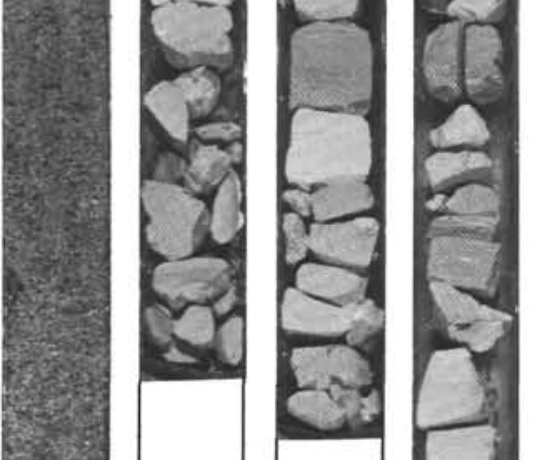

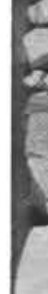

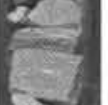

.
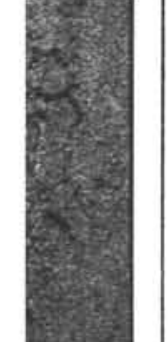

.
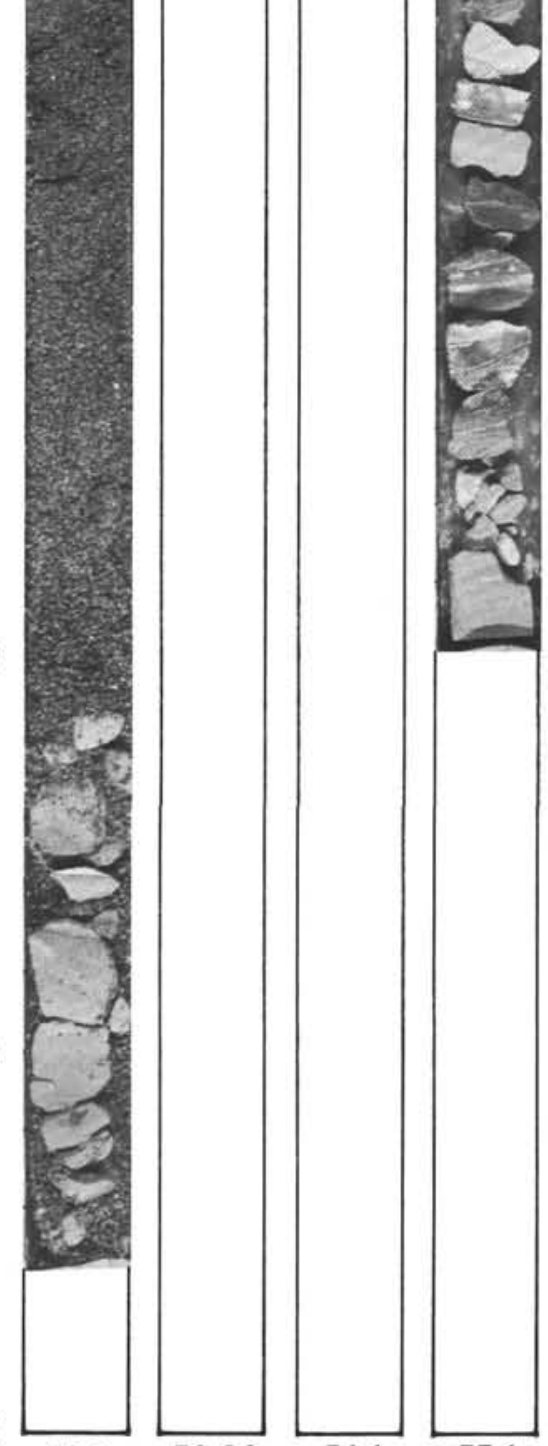

53-1 


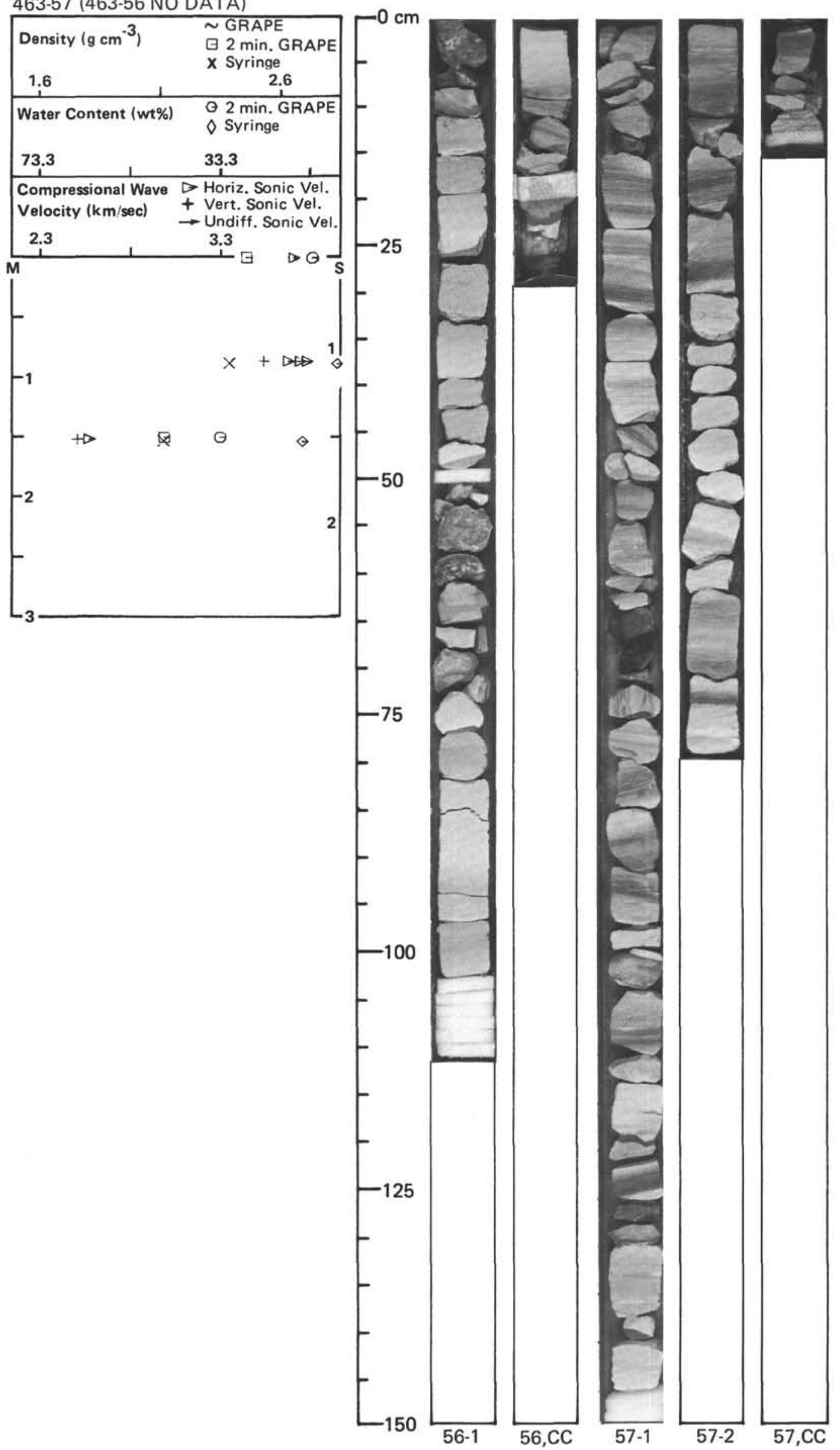




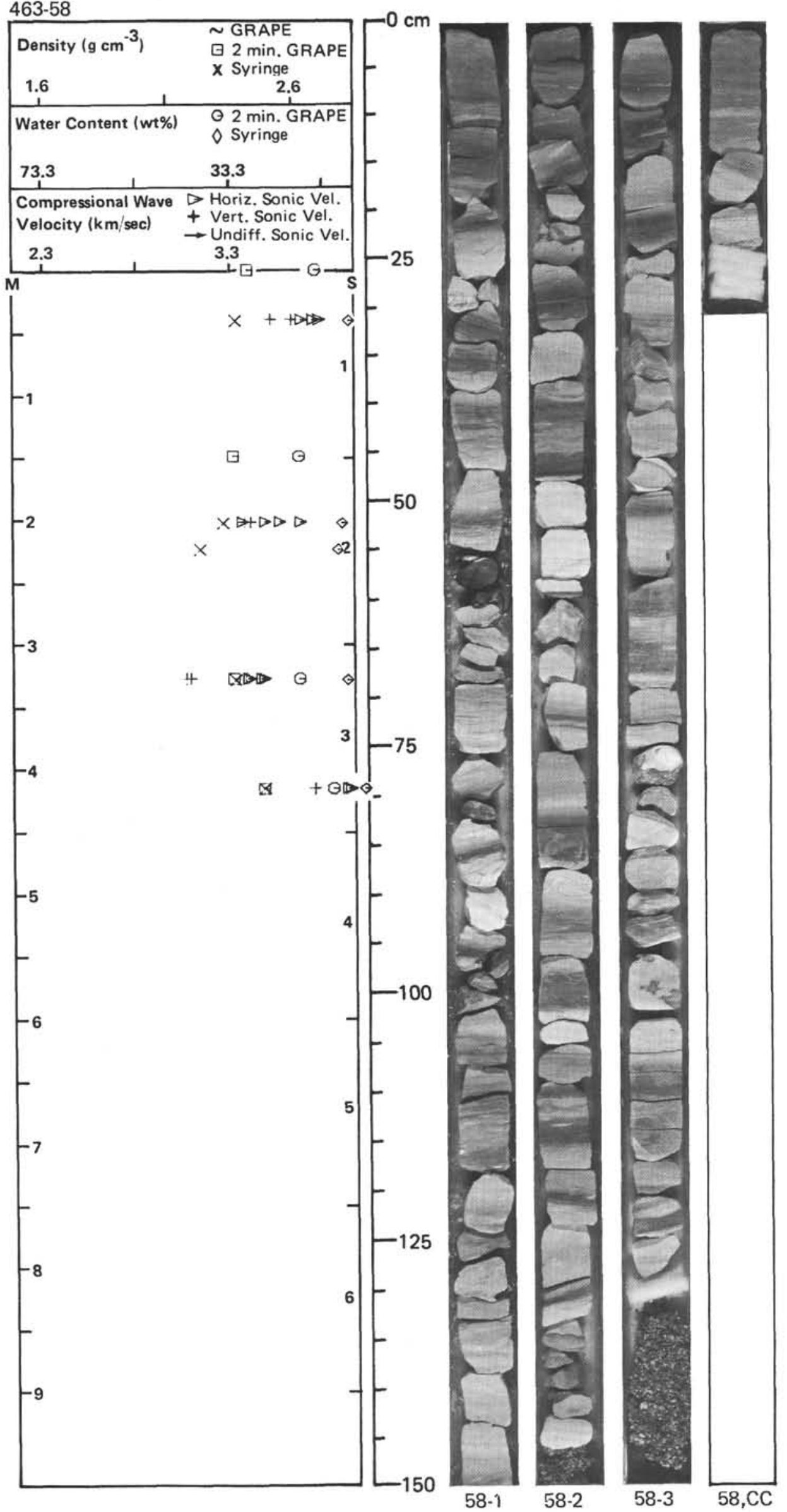




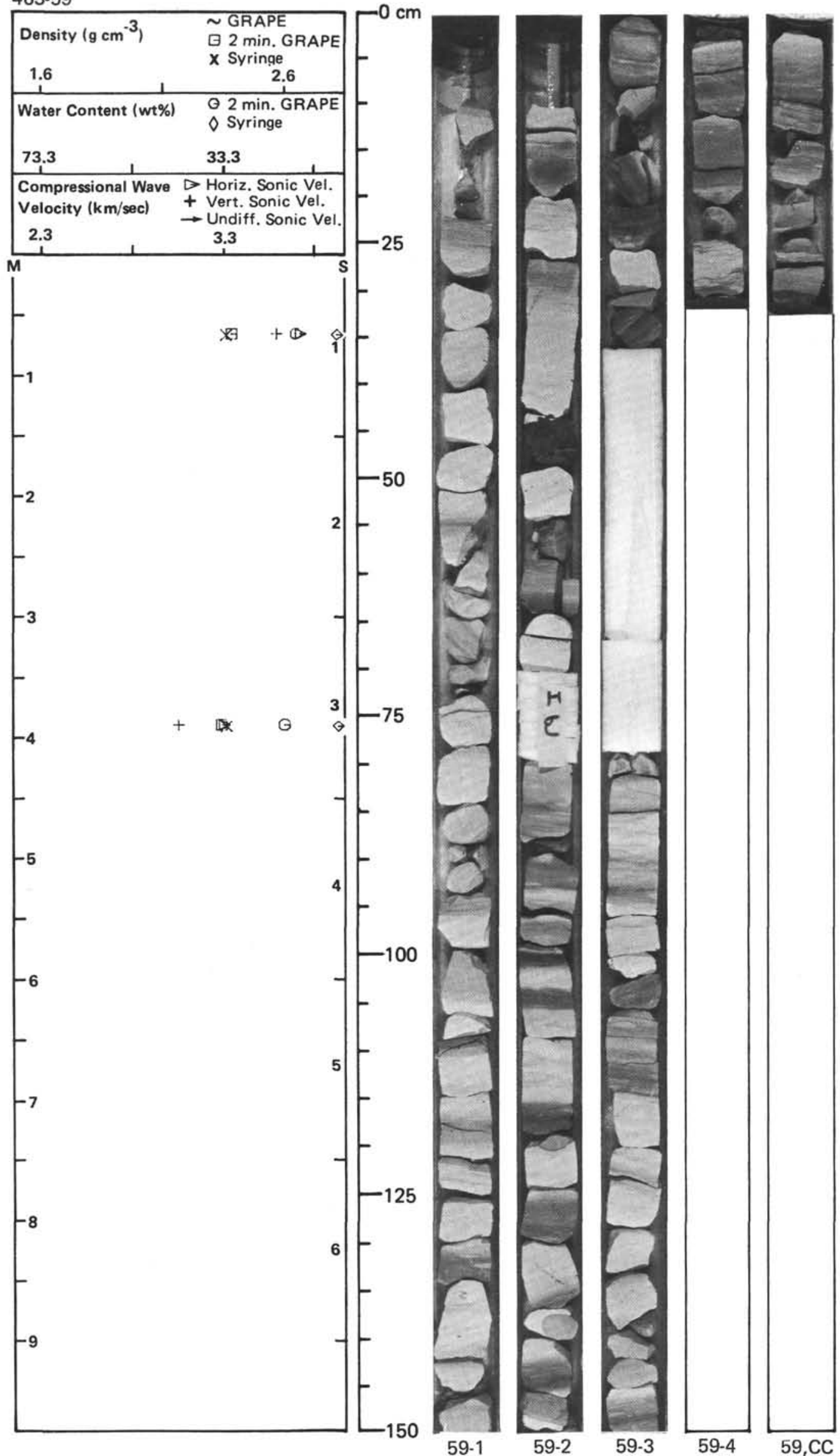


463-60

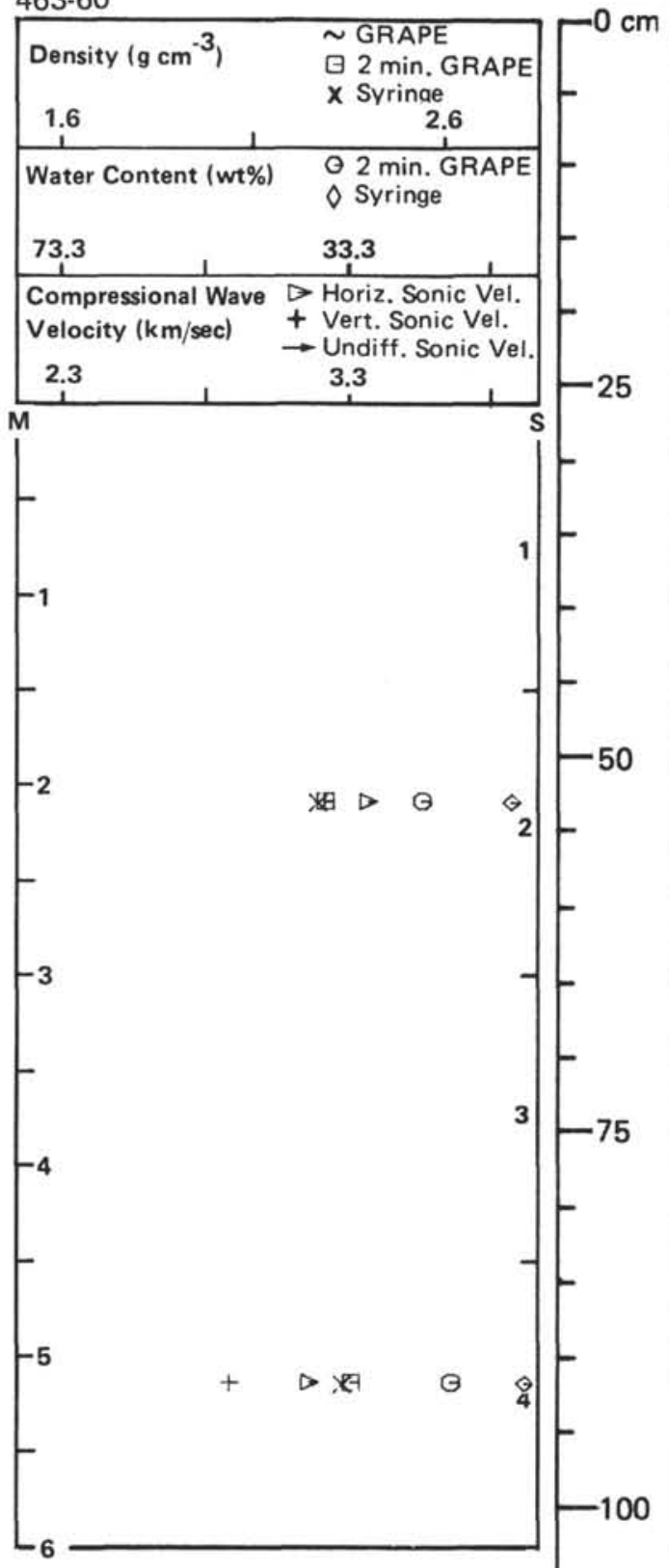

463-61

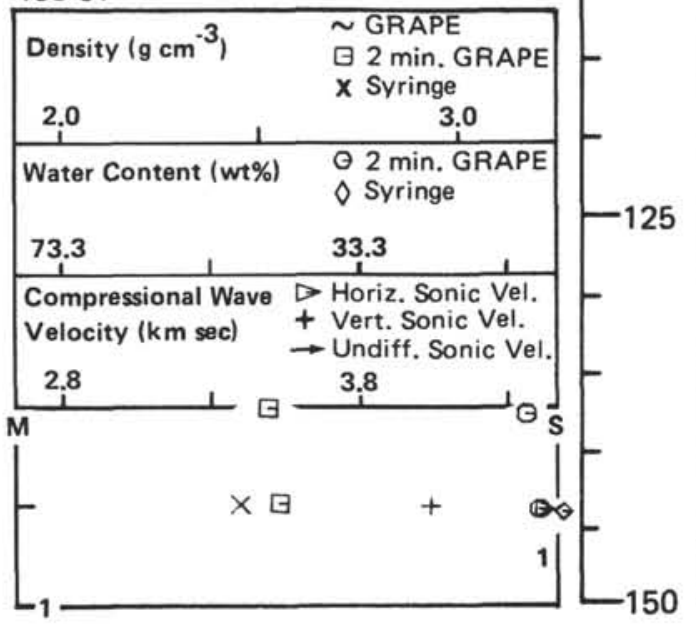

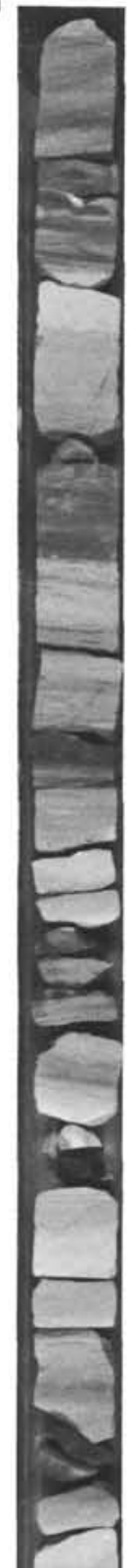
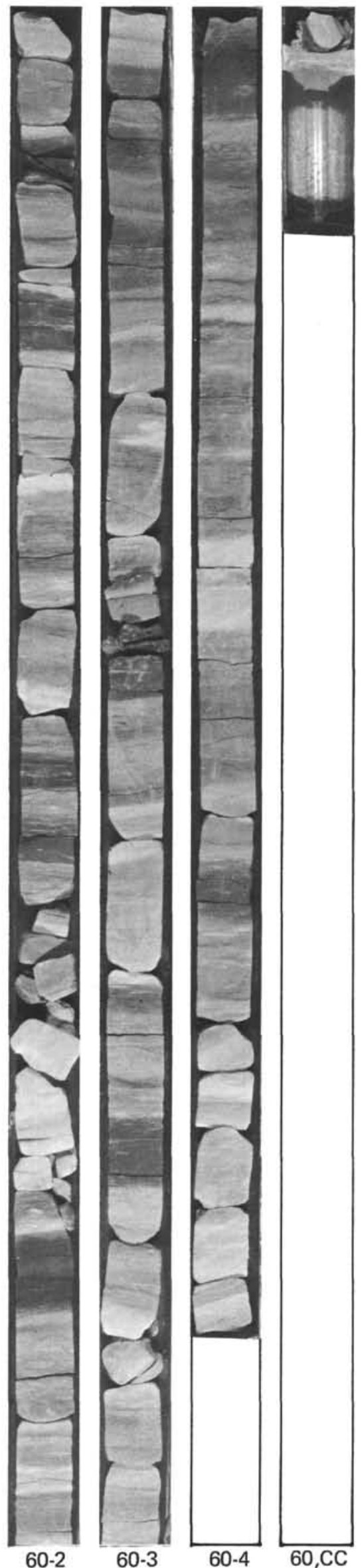
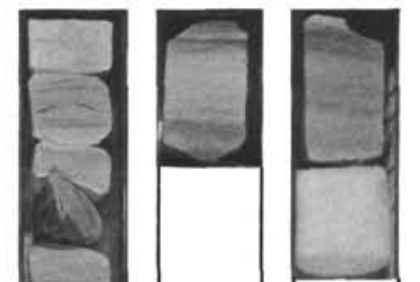

\section{5}

달

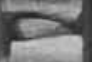

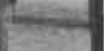

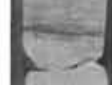

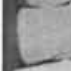
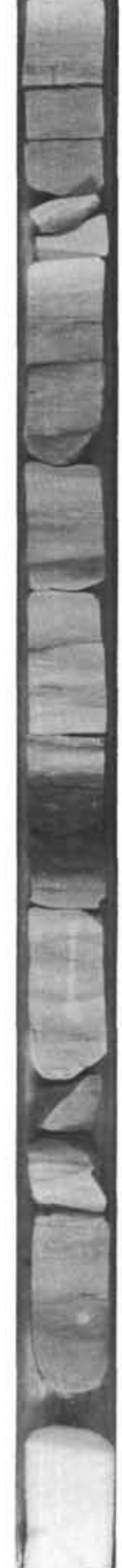

61-1

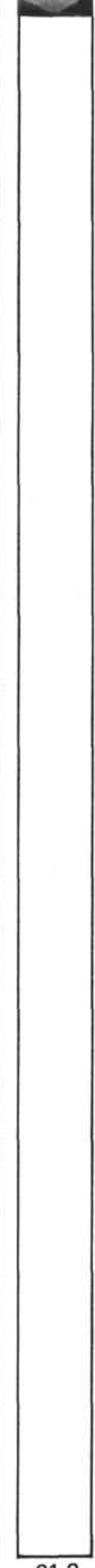




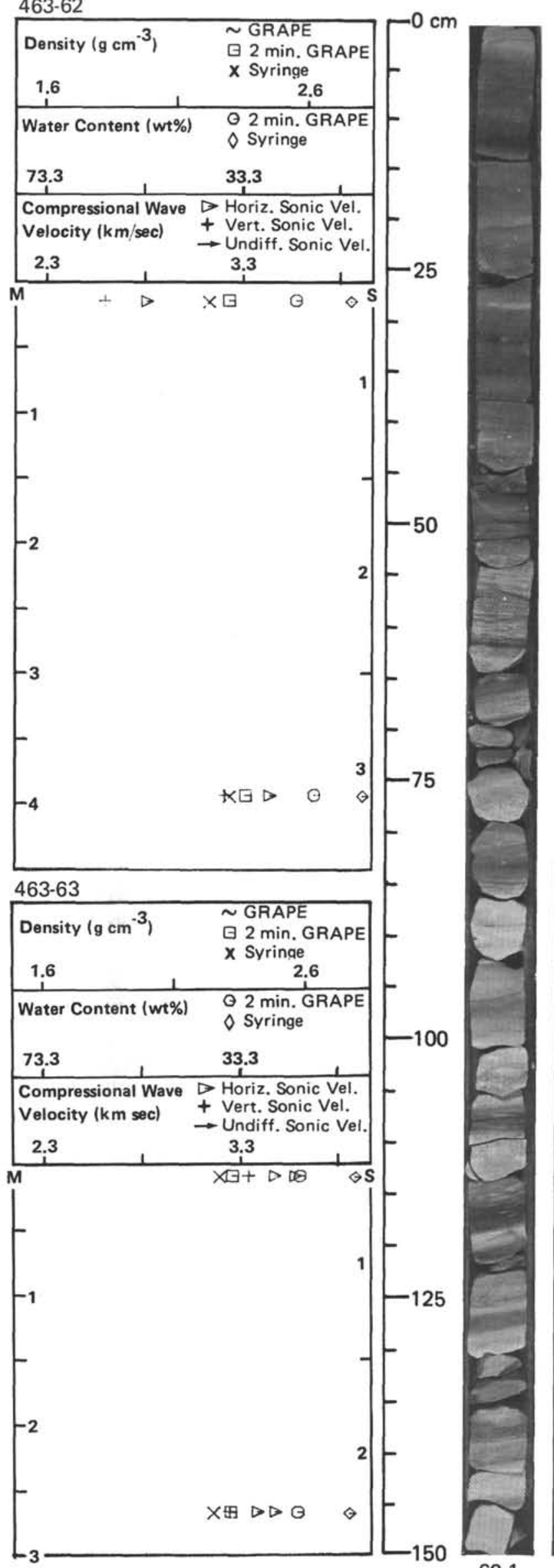

62-1

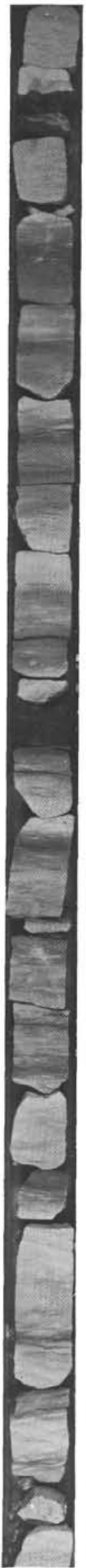

62-2

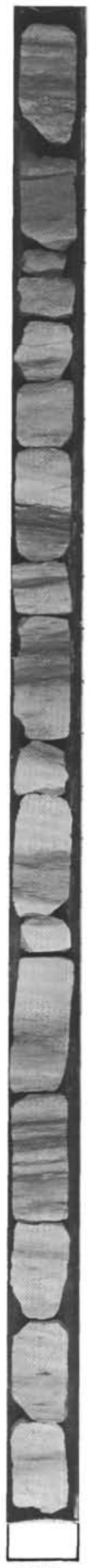

$62-3$

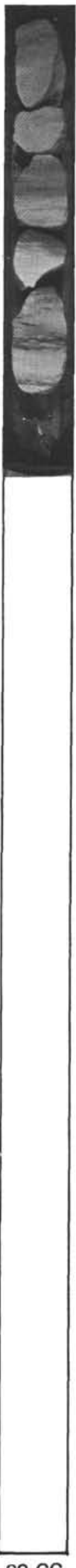

$62, \mathrm{CC}$

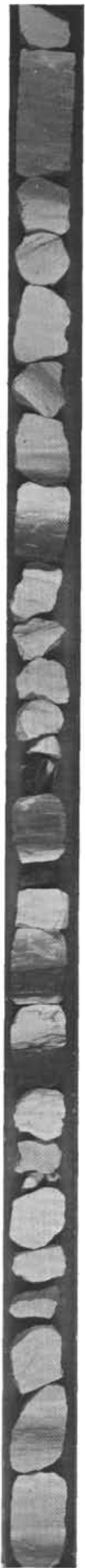

63-1

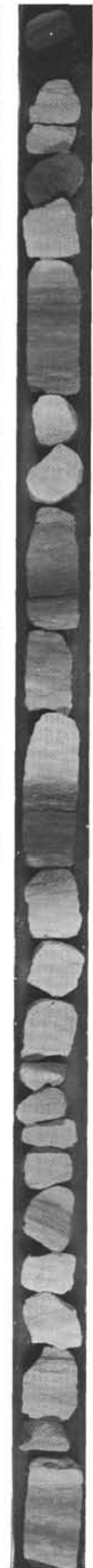

$63-2$
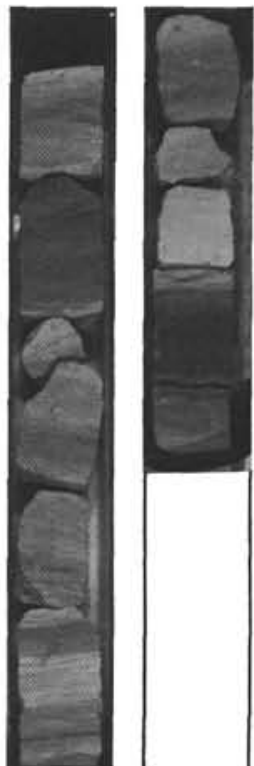
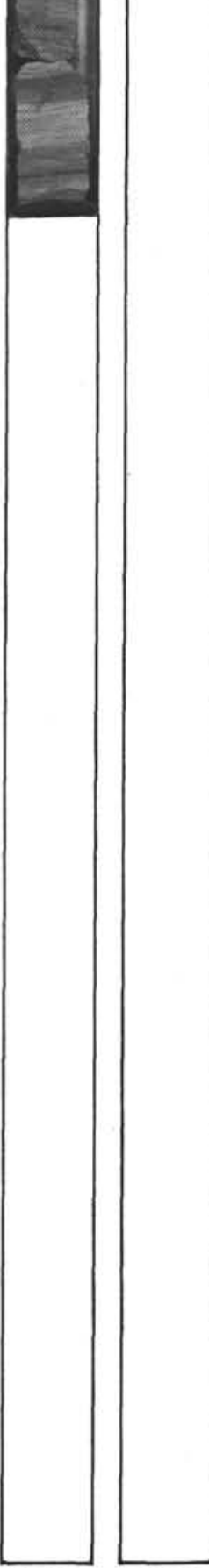

$63-3 \quad 63, \mathrm{CC}$ 
463-64

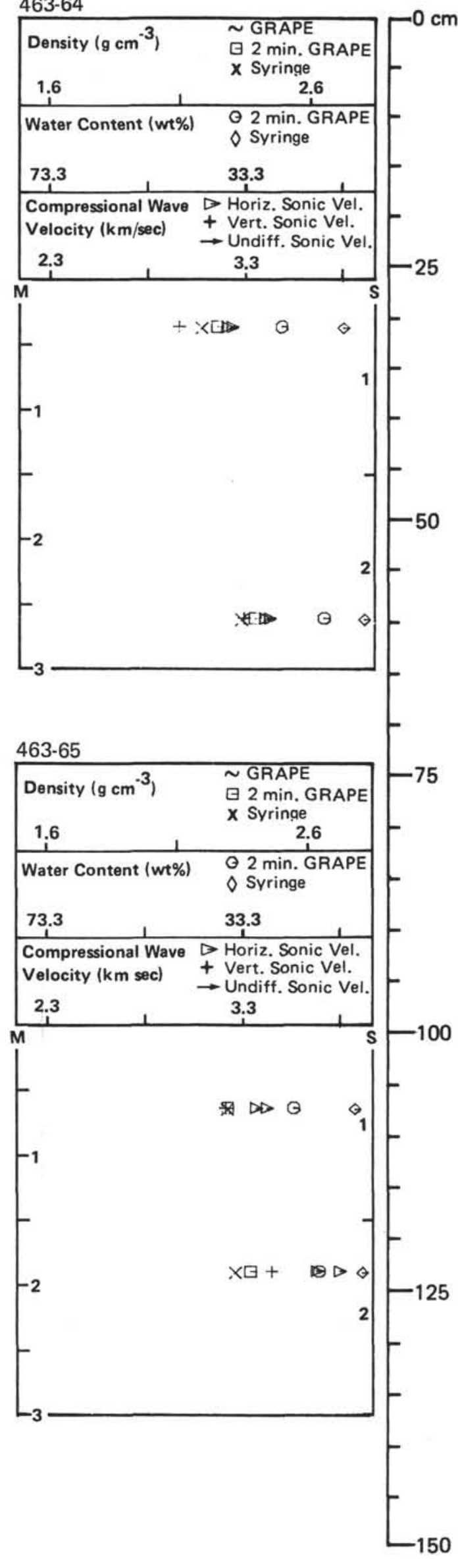

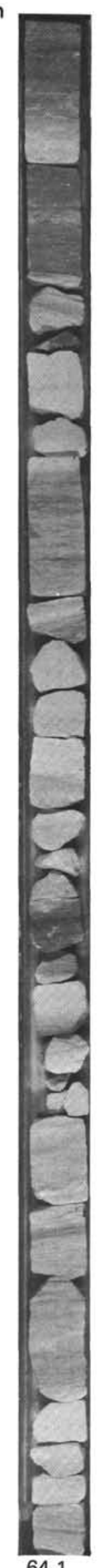

64-1

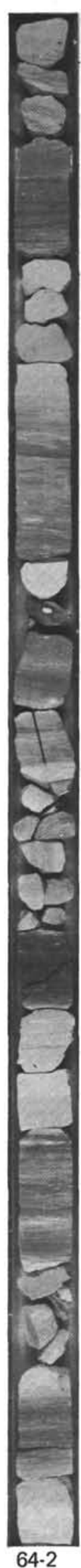

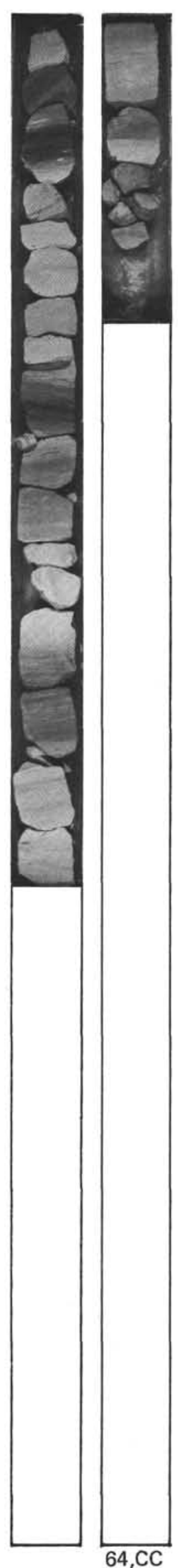
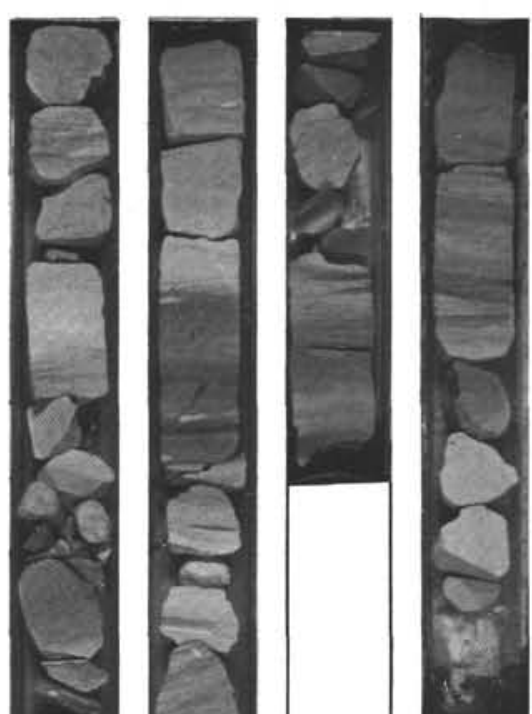

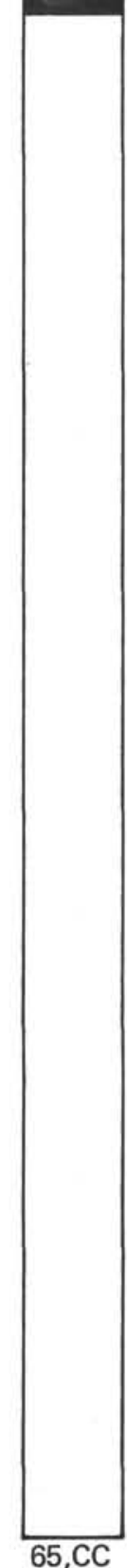




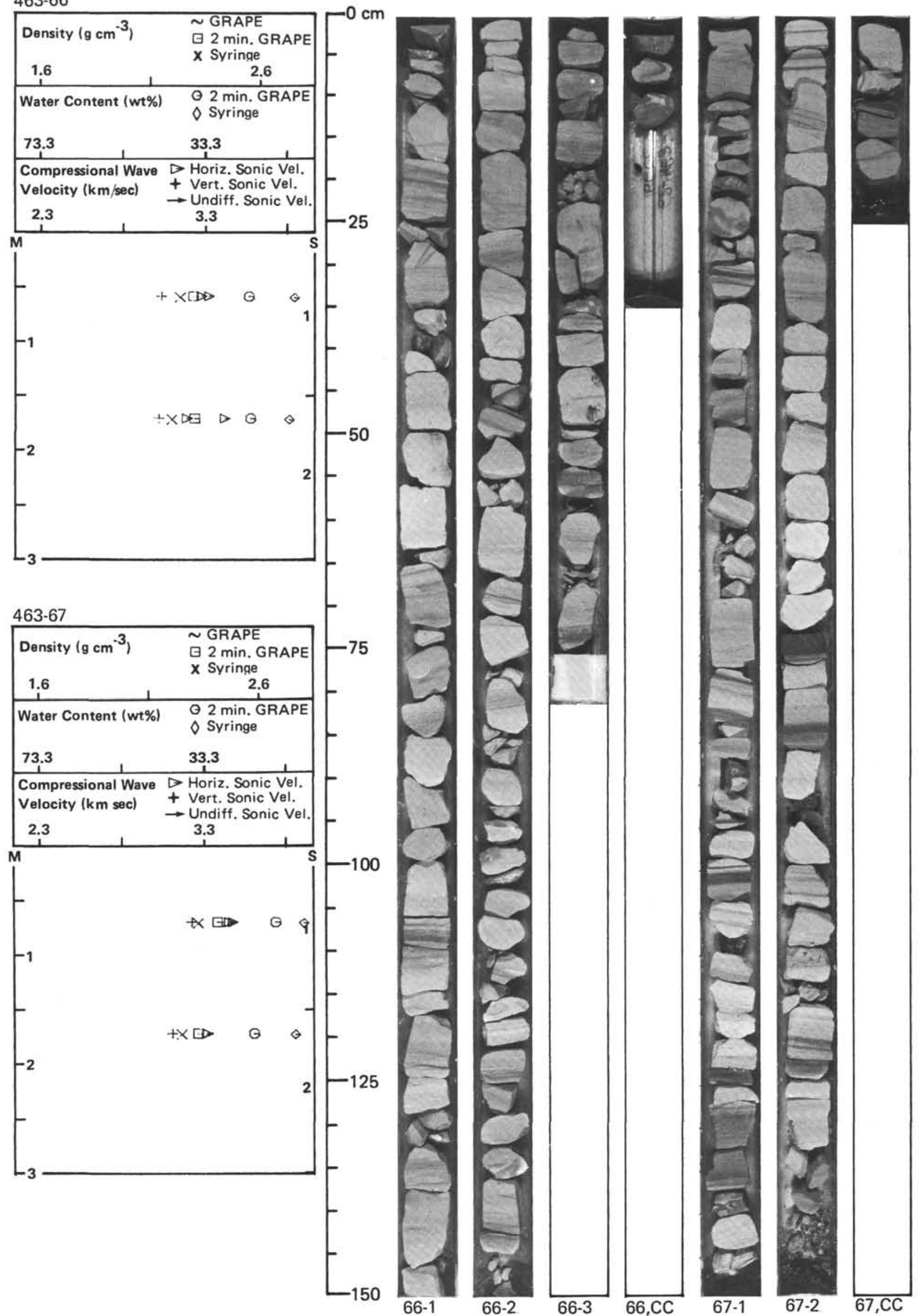




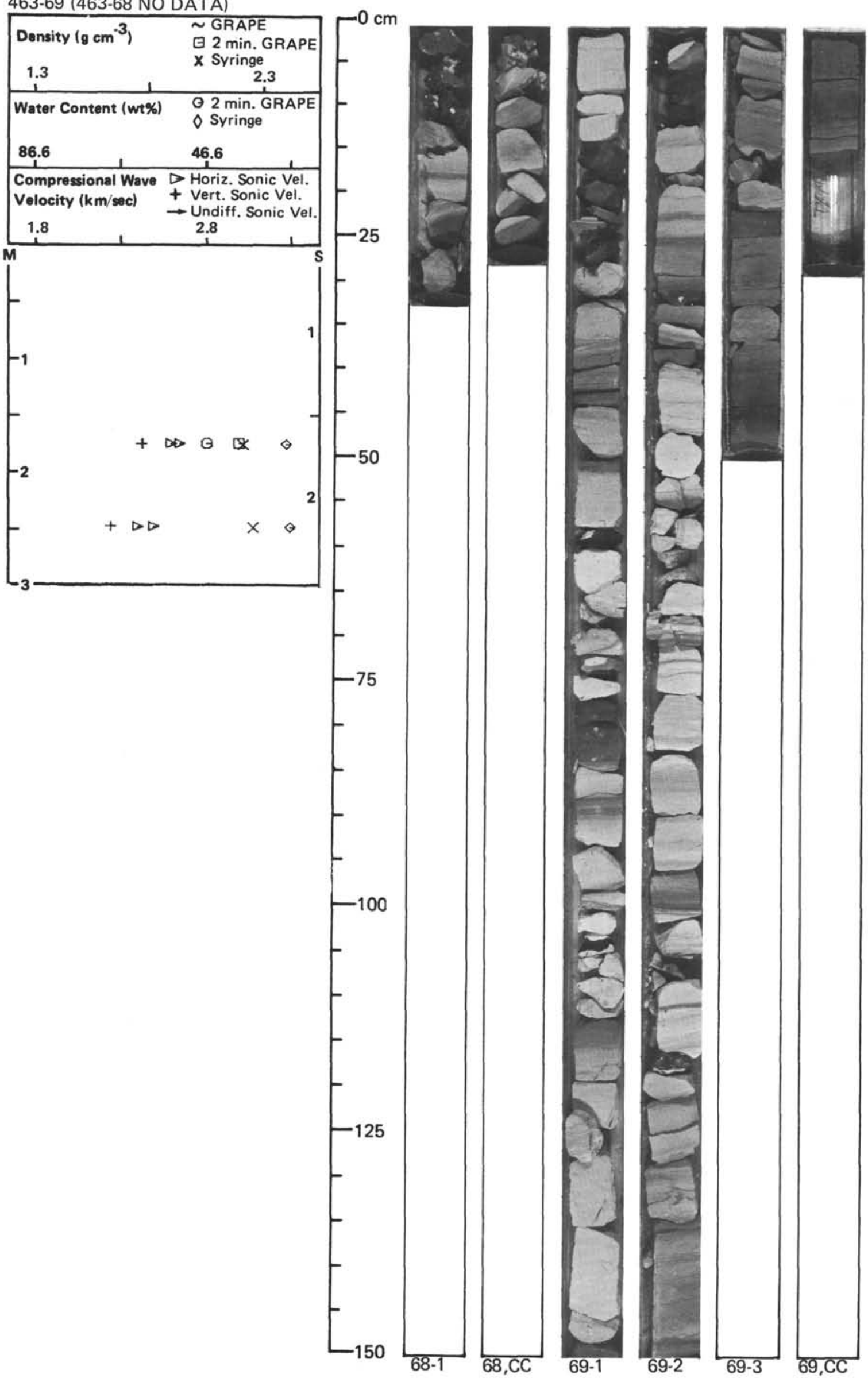




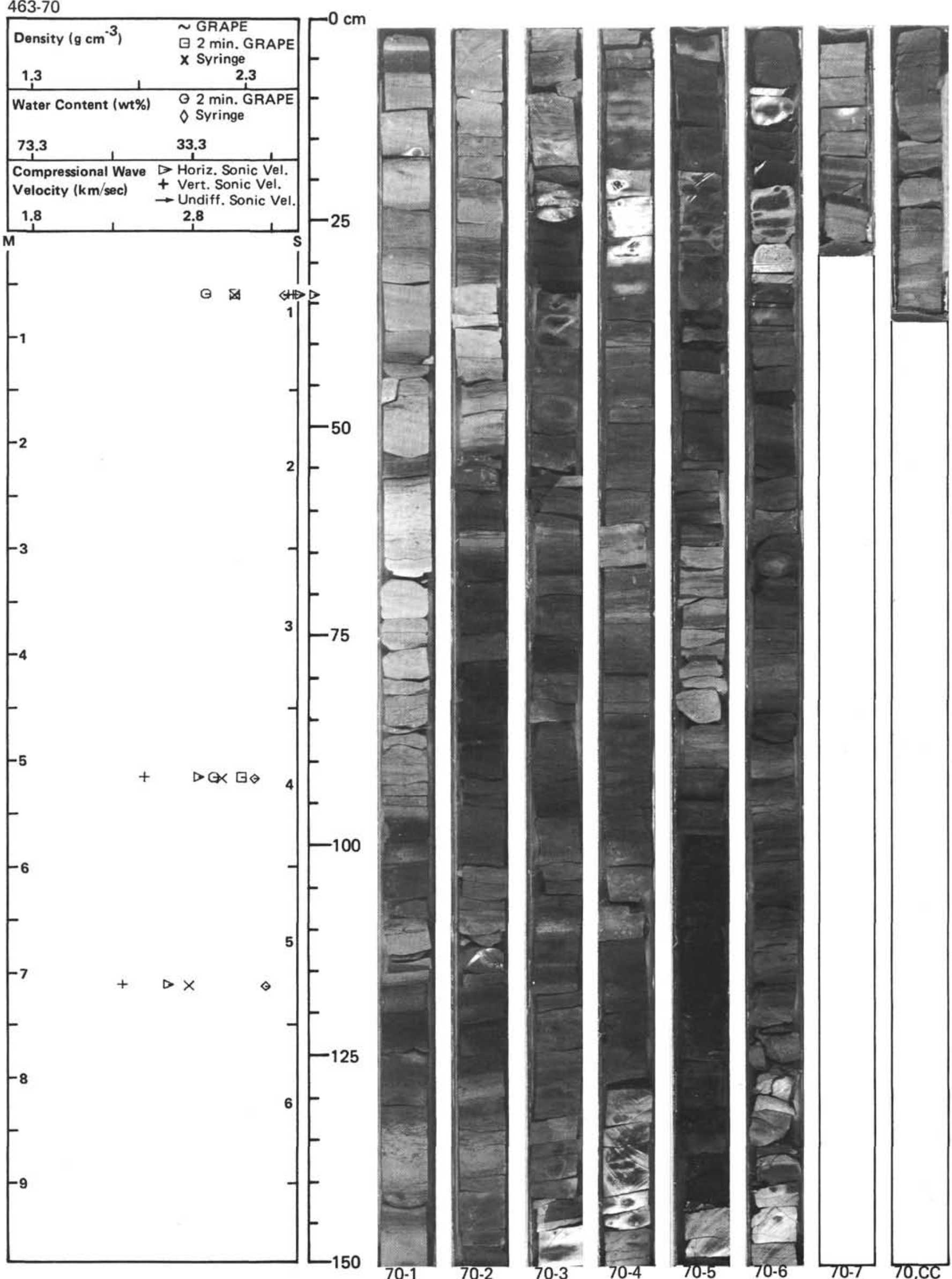




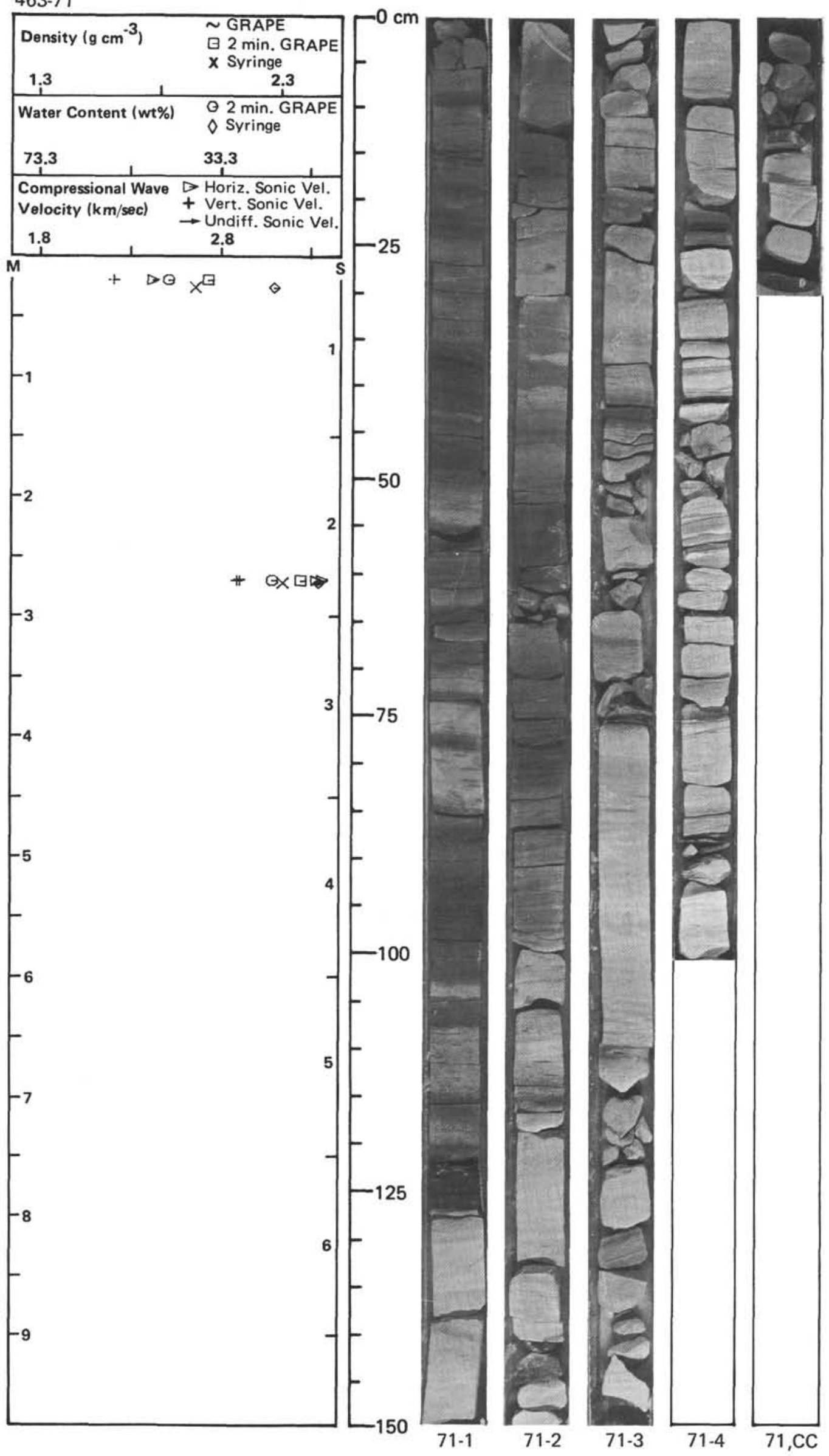




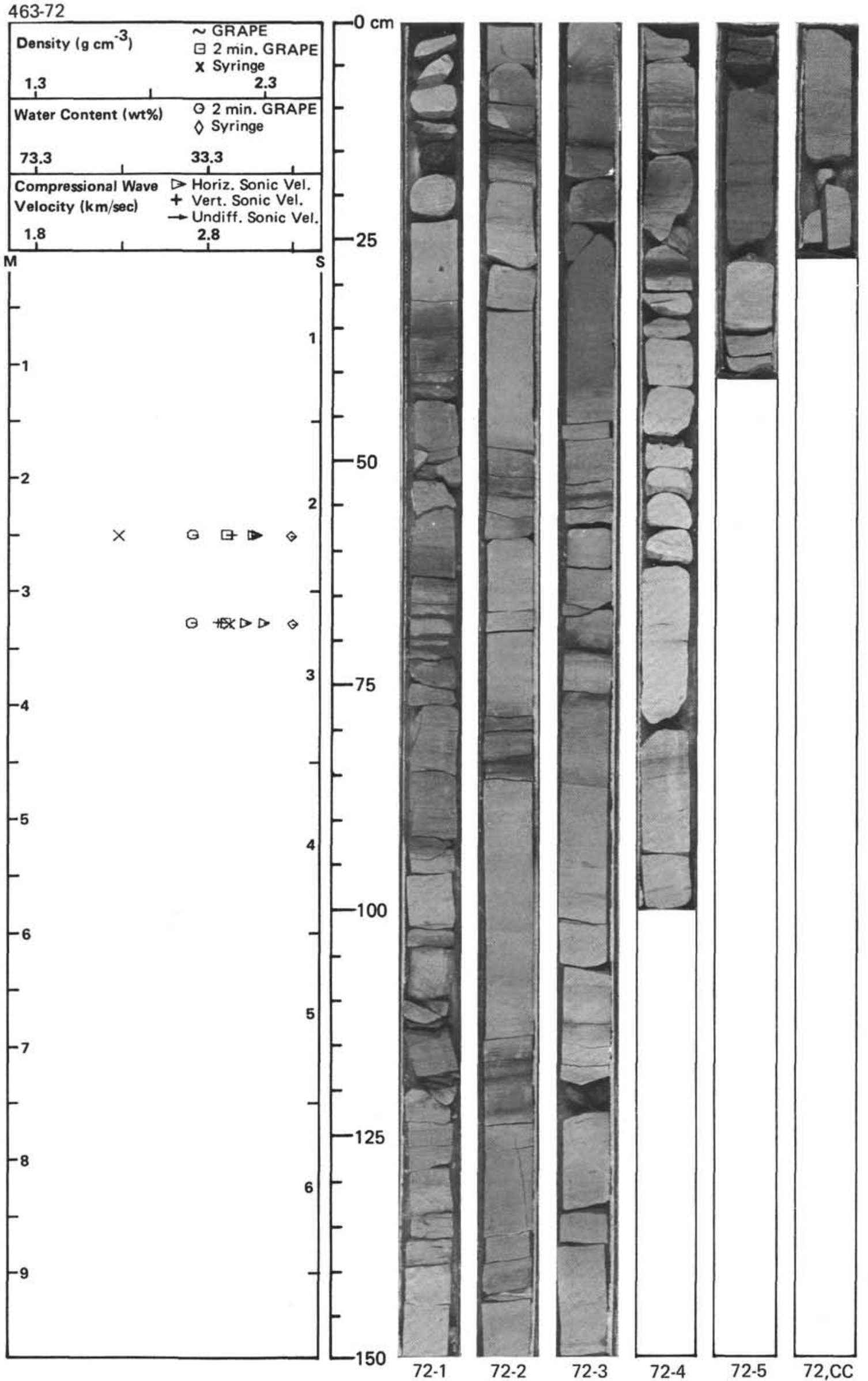


463-73

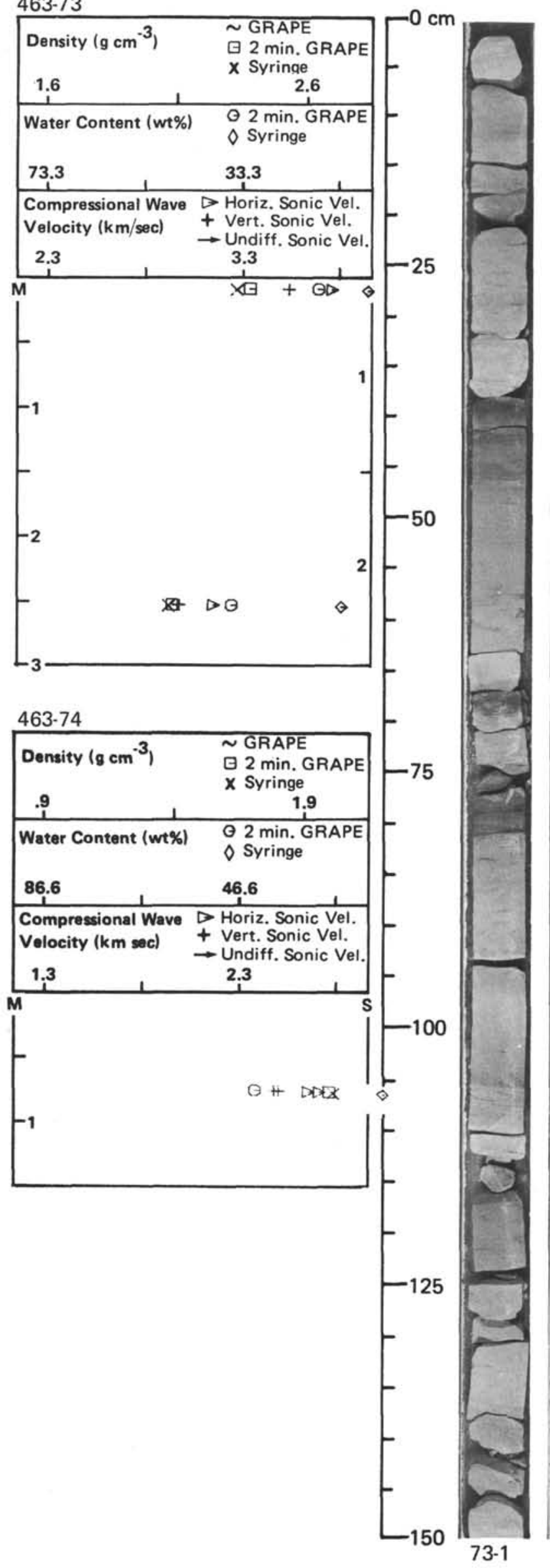

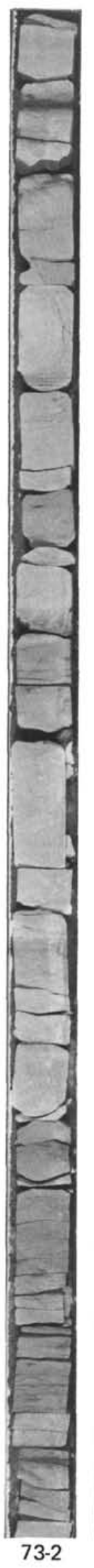

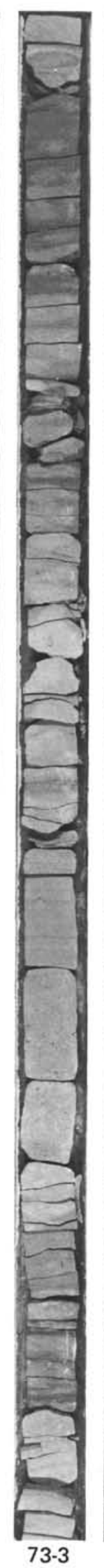

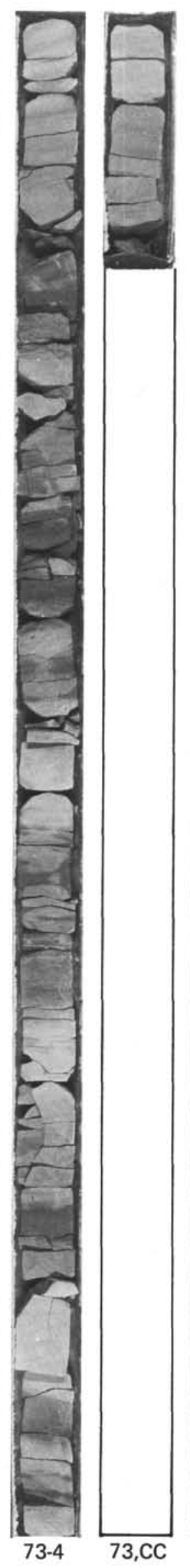
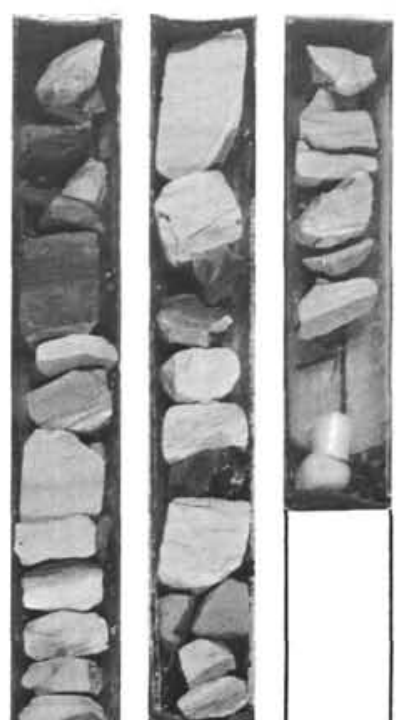

\section{2}

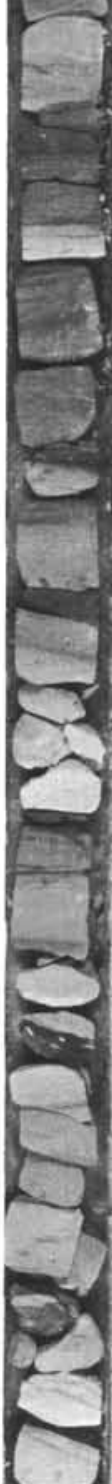

74-1

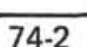


463-76 (463-75 NO DATA

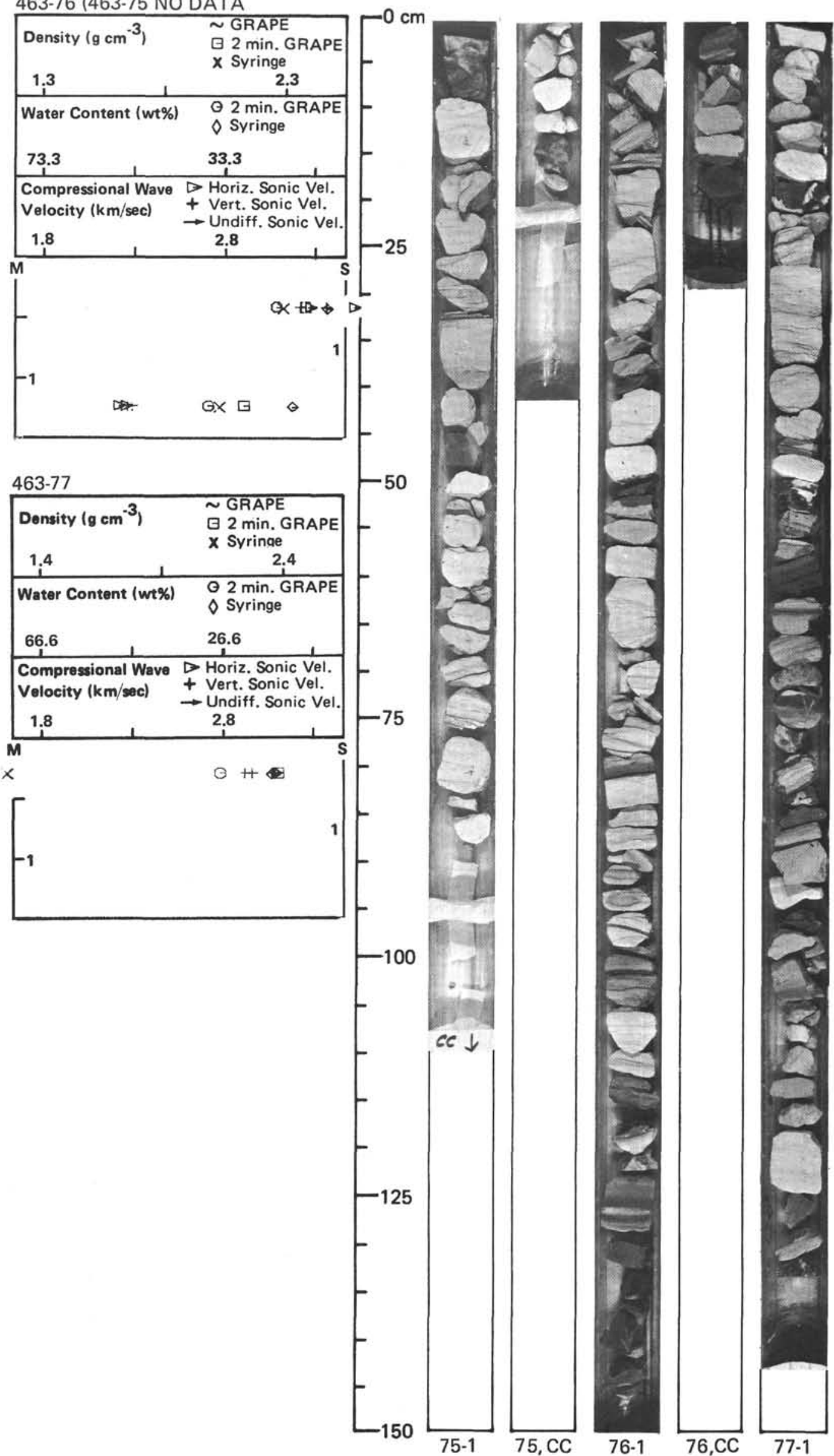


463-78

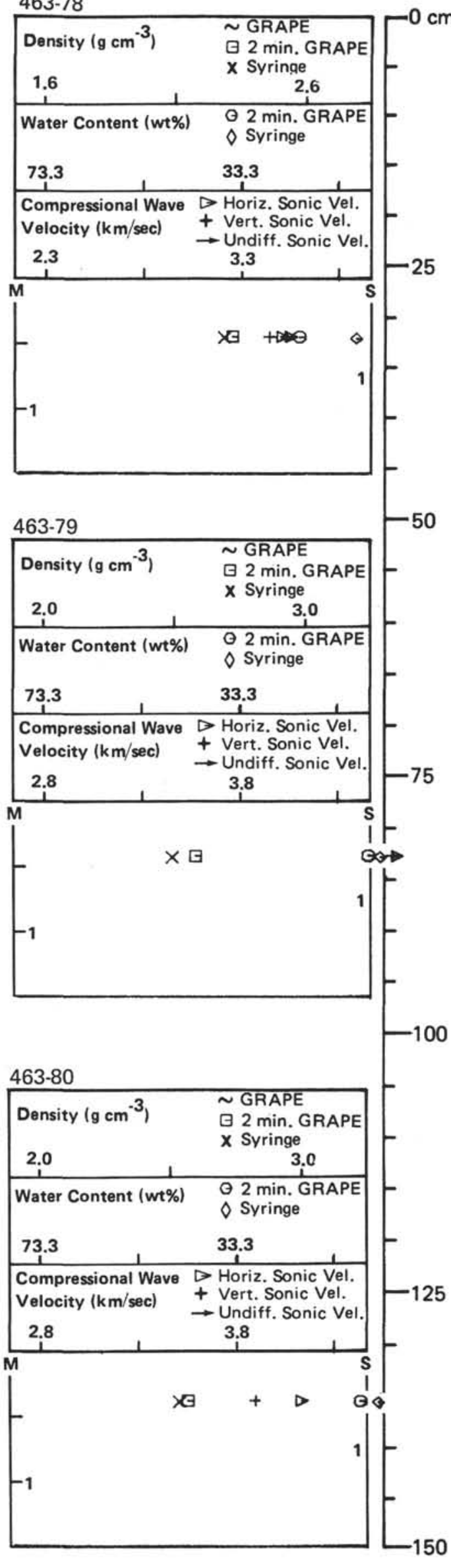

ran

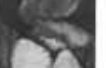

군
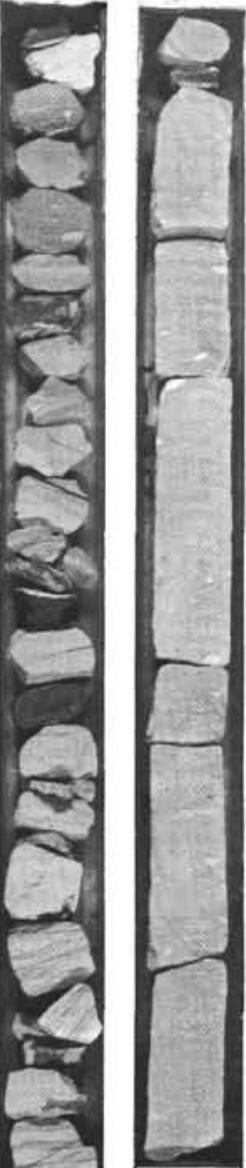

b-

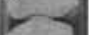

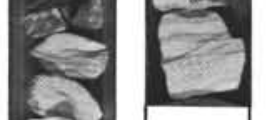

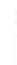

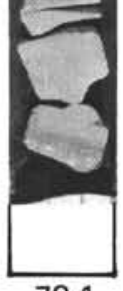

78-1 


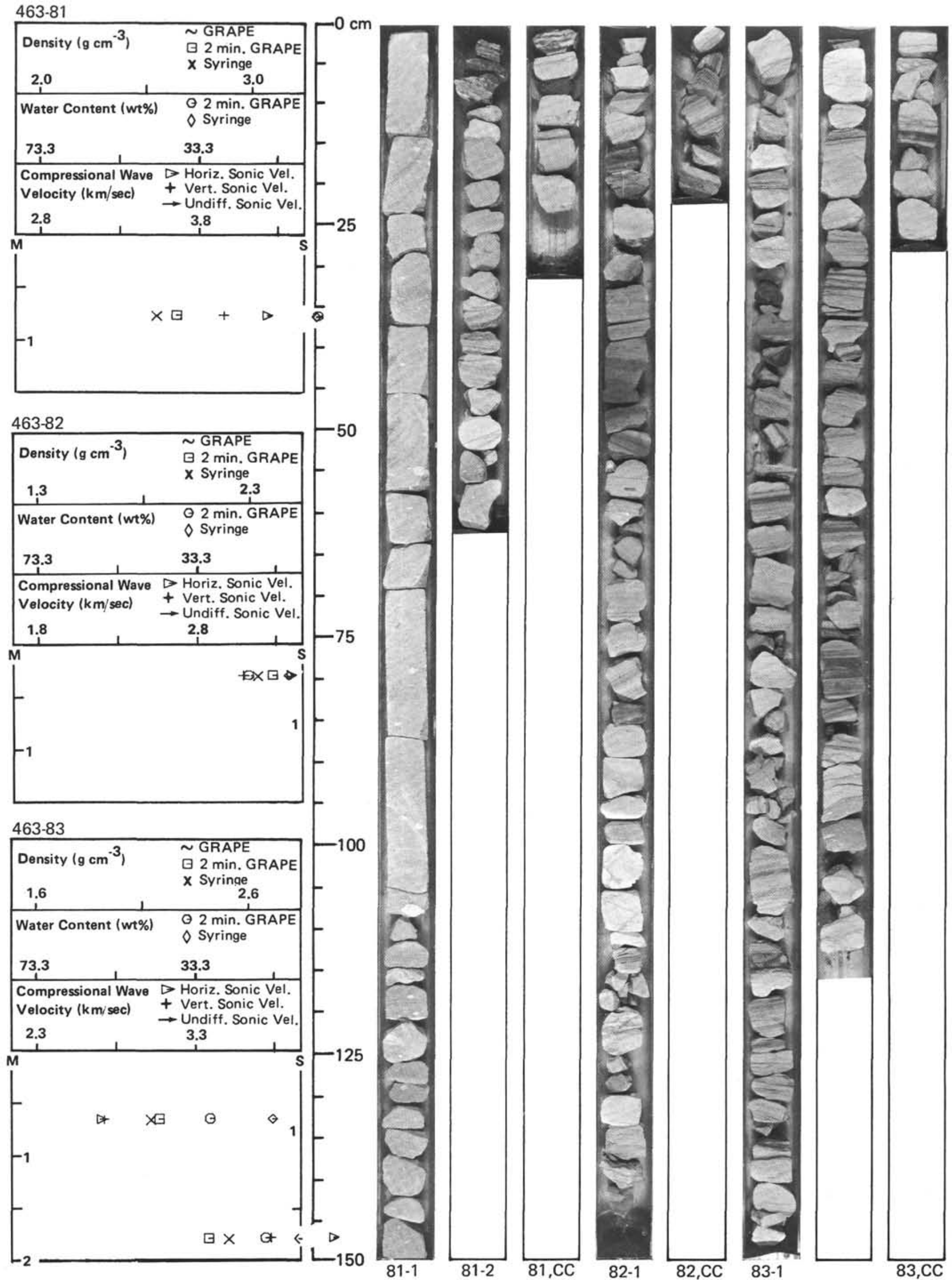


463-84

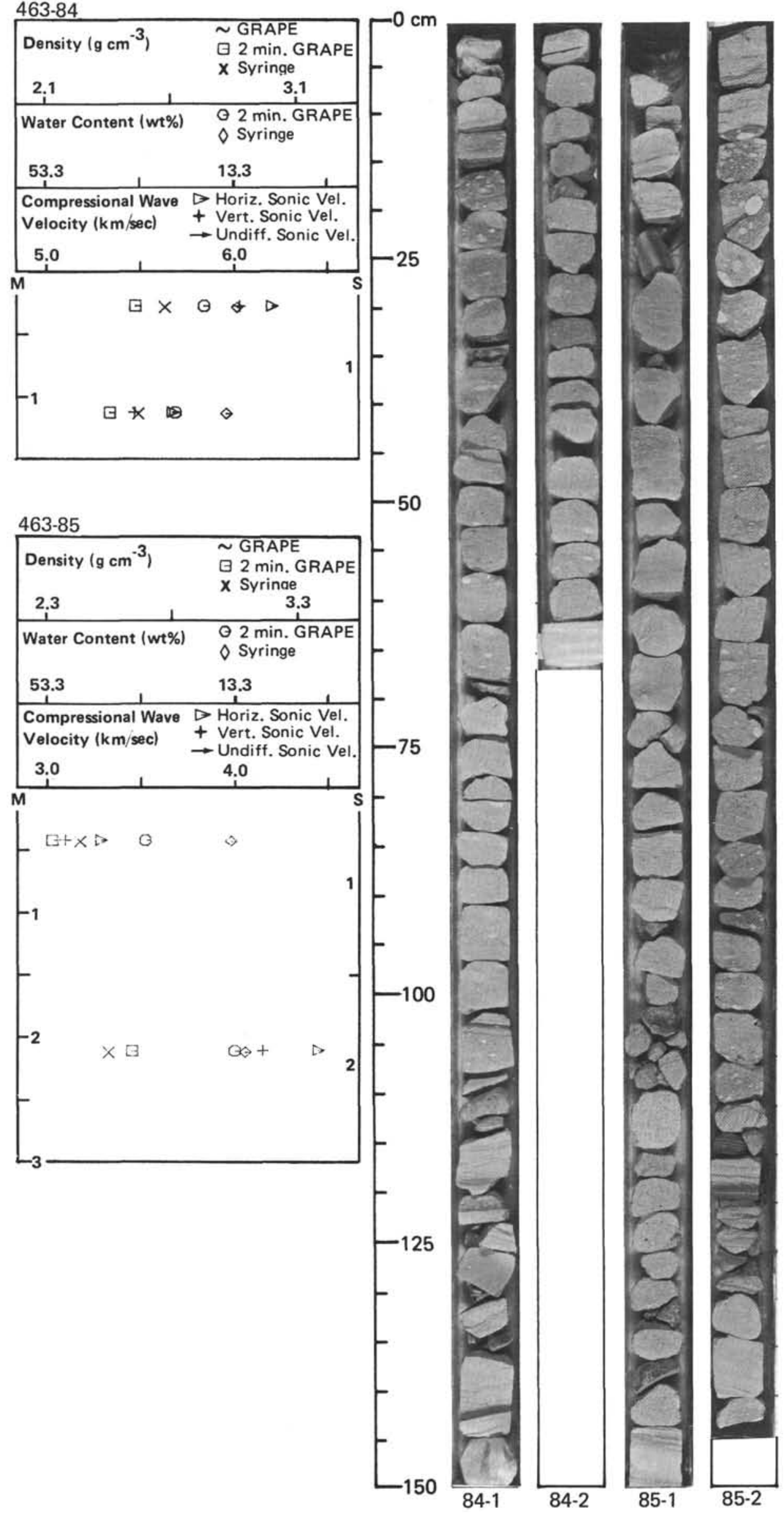



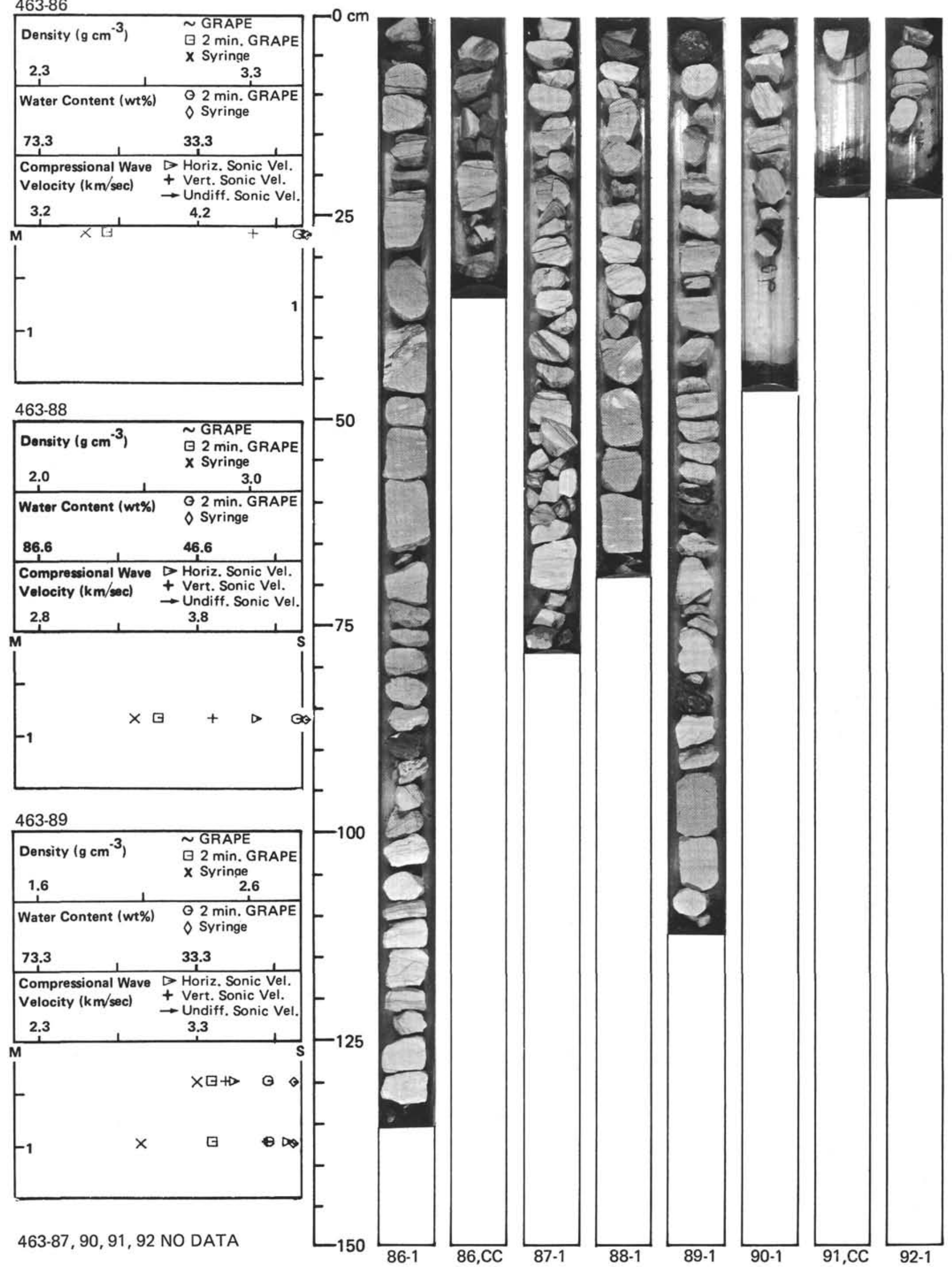

89-1

90-1 